\title{
Remoção de Alquilbenzeno Linear Sulfonado (LAS) e Caracterização Microbiana em Reator Anaeróbio de Leito Fluidificado
}

Tese apresentada à Escola de Engenharia de São Carlos da Universidade de São Paulo para obtenção do título de Doutora em Engenharia.

Orientadora: Profa. Dra. Maria Bernadete A. Varesche Co-Orientador: Prof. Dr. Edson Luiz Silva

São Carlos

2010 
AUTORIZO A REPRODUÇÃO E DIVULGAÇÃO TOTAL OU PARCIAL DESTE TRABALHO, POR QUALQUER MEIO CONVENCIONAL OU ELETRÔNICO, PARA FINS DE ESTUDO E PESQUISA, DESDE QUE CITADA A FONTE.

Ficha catalográfica preparada pela Seção de Tratamento da Informação do Serviço de Biblioteca - EESC/USP

\section{Oliveira, Lorena Lima de}

Remoção de alquilbenzeno linear sulfonado (LAS) e caracterização microbiana em reator anaeróbio de leito fluidificado / Lorena Lima de Oliveira ; orientadora Maria Bernadete A. Varesche, co-orientador: Edson Luiz Silva. -- São Carlos, 2010.

Tese (Doutorado-Programa de Pós-Graduação e Área de Concentração em Hidráulica e Saneamento) -- Escola de Engenharia de São Carlos da Universidade de São Paulo, 2010 .

1. Areia. 2. Argila expandida. 3. Carvão ativado. 4. Reatores de leito fluidificado. 5. Reatores anaeróbios. 6. Surfactantes. 7. LAS. 8. Gene 16S RNAr. I. Título. 
Candidato(a): Engenheira LORENA LIMA DE OLIVEIRA.

Tese defendida e julgada em 19/02/2010 perante a Comissão Julgadora:
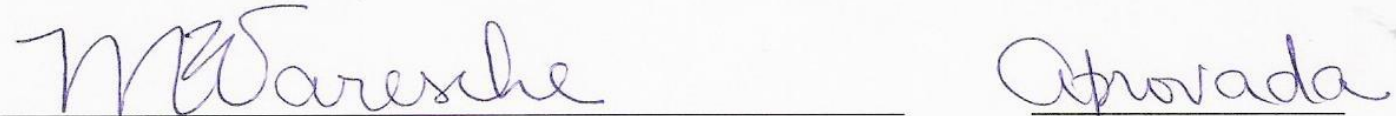

$\operatorname{Prof}^{a}$. Dr ${ }^{a}$. MARIA BERNADETE AMÂNCIO VARESCHE SILVA- (Orientadora)

(Escola de Engenharia de São Carlos/USP)

\section{Jhuato.}

Prof ${ }^{a}$. Dr ${ }^{a}$. IOLANDA CRISTINA SILVEIRA DUARTE

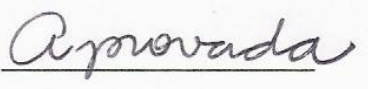

(Universidade Federal de São Carlos/UFSCar)

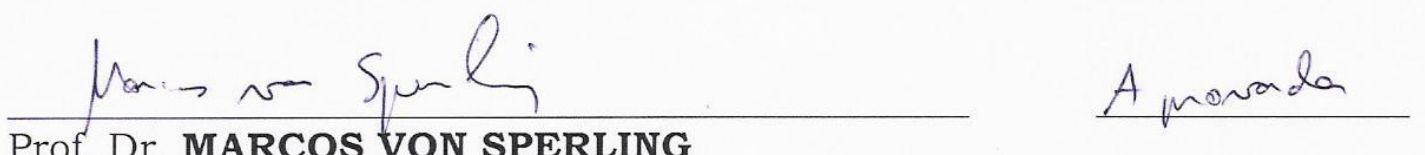

Prof. Dr. MARCOS VON SPERLING

(Universidade Federal de Minas Gerais/UFMG)

\section{Gullut}

Prof. Dr. SÉRGIO FRANCISCO DE AQUINO

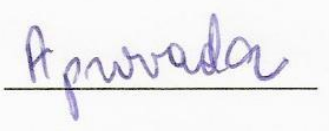

(Universidade Federal de Ouro Preto/UFOP)

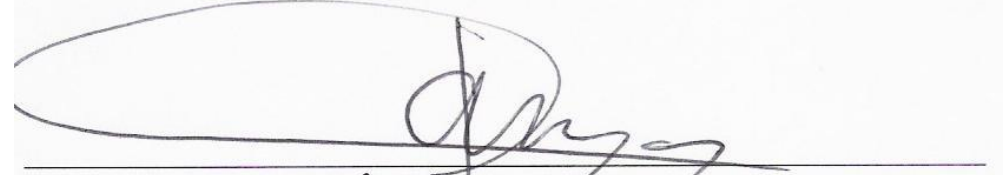

Prof. Titular JOSÉ RQBBERT CAMPOS

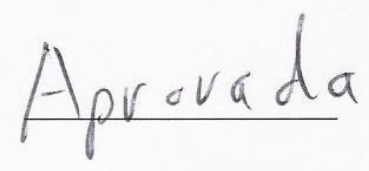

(Escola de Engenharia de São Carlos/USP)

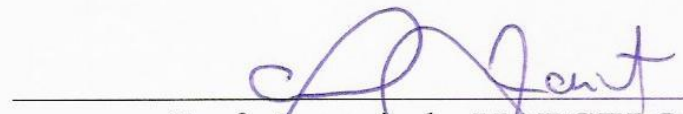

Prof. Associado MARCELO ZAIAT

Coordenador do Programa de Pós-Graduação em

Engenharia Hidráulica e Saneamento

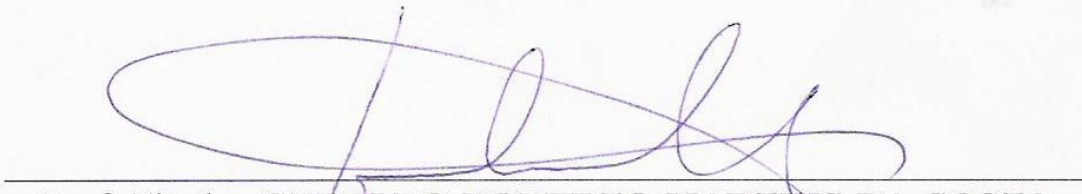

Prof. Titular GERALDO ROBERTO MARTINS DA COSTA

Presidente da/Comissão da Pós-Graduação da EESC 
Dedico este trabalho a meu marido Fábio, com amor, admiração e gratidão por sua compreensão, carinho, presença e incansável apoio ao longo do período de elaboração deste trabalho. 


\section{AGRADECIMENTOS}

A Deus, pelo dom da vida, pela saúde e pela fé em seguir em frente.

À minha orientadora, Profa. Dra. Maria Bernadete A. Varesche, pela permanente presença e orientação, por estar sempre pronta a ensinar e ajudar. Obrigada pelo seu apoio e compreensão.

Ao Prof. Dr. Edson Luiz Silva pela confiança e colaboração. Obrigada pelas dicas valiosas na construção dos reatores.

À querida amiga, Profa. Dra. Iolanda Cristina Silveira Duarte (Tininha) por seu companheirismo e disponibilidade na colaboração deste trabalho.

Aos colegas Dagoberto Yukio Okada e Rachel Biancalana Costa por partilharem comigo essa idéia. Obrigada pelo suporte e apoio nas horas difíceis.

Aos professores Eugênio Foresti e Marcelo Zaiat pelo incentivo, disposição e boas sugestões dadas durante este trabalho.

À Janja pelas dicas preciosas em cromatografia, conselhos e orientação no laboratório. Obrigada pelo carinho e amizade.

Às amigas Dani e Isabel pela ajuda nas análises de Biologia Molecular.

A todos os amigos do laboratório em especial, Amanda, Ana Flávia, Ariane, Berna, Bruna, Carol, Dago, Dani, Eduardo, Eloísa, Irene, Isabel, Janja, Márcia, Rachel, Regiane, Renata, Sandra, Theo, Tininha e Tiago. Obrigada pelos bons momentos de convivência durante esses anos e pelo carinho que demostraram ao partilharem comigo a chegada do Murilo.

Aos funcionários do SHS pelo auxílio e boa vontade.

À Escola de Engenharia de São Carlos (USP) pela oportunidade de realização do doutorado.

À FAPESP pela concessão da bolsa de doutorado e pelo apoio financeiro para a realização desta pesquisa.

Ao meu marido e amigo Fábio por estar ao meu lado, me apoiando em minhas decisões e partilhando comigo este trabalho.

Ao meu filho Murilo que chegou durante a relização deste trabalho e transformou minha vida.

Aos meus pais, Mário e Josélia pelo encorajamento, paciência e compreensão.

Ao meu irmão (e compadre) Matheus, por partilhar comigo a idéia da pós-graduação e estar sempre presente. 
A toda minha família e amigos pelo incentivo e carinho.

A todos que convivi durante a realização deste trabalho, agradeço pela compreensão, atenção, companheirismo e pela troca de conhecimentos que foi muito importante para meu crescimento profissional e pessoal. 


\section{RESUMO}

\section{OLIVEIRA, L. L. Remoção de Alquilbenzeno Linear Sulfonado (LAS) e Caracterização}

Microbiana em Reator Anaeróbio de Leito Fluidificado. 2009. 176 f. Tese (Doutorado) Escola de Engenharia de São Carlos, Universidade de São Paulo, São Carlos, 2010.

Nesse trabalho foi estudado a degradação anaeróbia do alquilbenzeno linear sulfonado (LAS), um surfactante amplamente utilizado na fabricação de detergentes e presente em esgoto doméstico e águas residuárias industriais. Para isso foi utilizado reator anaeróbio de leito fluidificado em escala de bancada $(1,2 \mathrm{~L})$ preenchido com material suporte para imobilização da biomassa. Quatro diferentes suportes foram testados previamente em reatores de leito fluidificado em menor escala $(350 \mathrm{ml})$ : carvão ativado (R1), argila expandida (R2), pérolas de vidro (R3) e areia (R4). Todos os reatores foram inoculados com lodo proveniente de reator UASB utilizado no tratamento de dejetos de suinocultura e alimentados com substrato sintético acrescido de LAS. Os reatores foram mantidos a $30^{\circ} \mathrm{C}$ e operados com tempo de detenção hidráulica (TDH) de 18 horas. Foi possível constatar que os quatro reatores foram aptos na remoção de matéria orgânica (acima de 84\%) e LAS (acima de 81\%), respectivamente para concentração inicial média de $550 \mathrm{mg} / \mathrm{L}$ e 16,5 mg/L. No entanto, carvão ativado e argila expandida sofreram processo de fragmentação durante a operação do reator. Assim, areia foi o material escolhido para preencher o reator em escala de bancada devido aos bons resultados de remoção do LAS (99\%), menor custo e facilidade de aquisição, quando comparada a pérola de vidro. Após 270 dias de operação, com concentrações crescentes de LAS e média de $32,3 \mathrm{mg} / \mathrm{L}$, constatou-se que o reator em escala de bancada removeu 93\% de LAS. Todos os suportes adsorveram pouco LAS (máximo de 0,43 $\mathrm{mg}_{\text {LAS }} / \mathrm{g}_{\text {argila }}$ ) não interferindo significativamente no processo de remoção biológica. Exames microscópicos realizados durante a operação dos reatores mostraram que estiveram presentes microrganismos com morfologias semelhantes a espiroquetas, bacilos, bactérias filamentosas e cocos, entre outros. A biomassa presente no final da operação do reator em escala de bancada e nos reatores menores preenchidos com pérolas de vidro (R3) e areia (R4) foi submetida à técnica de clonagem e sequenciamento do gene 16S RNAr para o Domínio Bacteria. Observou-se que os reatores apresentaram clones relacionados a diversos Filos como Bacteroidetes, Proteobacteria, Verrucomicrobia e Firmicutes, entre outros. 
Palavras-chave: Areia. Argila expandida. Carvão Ativado. Pérolas de Vidro. Reator de Leito Fluidificado. Degradação Anaeróbia. Surfactante. LAS. Gene 16S RNAr. 


\begin{abstract}
OLIVEIRA, L. L. Removal of Linear Alkylbenzene Sulfonate (LAS) and Microbial Characterization in Anaerobic Fluidized Bed Reactor. 2009. 176 f. Thesis (Doctoral) Escola de Engenharia de São Carlos, Universidade de São Paulo, São Carlos, 2010.

This work presents the anaerobic degradation of linear alkylbenzene sulphonate (LAS), a surfactant widely used in the production of detergents and present in domestic and industrial wastewaters. It was used an anaerobic fluidized bed reactor in bench scale $(1,2 \mathrm{~L})$ filled with support material for biomass immobilization. Four different supports were previously tested in small scale fluidized bed reactors $(350 \mathrm{ml})$ : activated charcoal (R1), expanded clay (R2), glass beads (R3) and sand (R4). All reactors were inoculated with sludge from a UASB reactor treating swine wastewater and were fed with a synthetic substrate supplemented with LAS. The reactors were kept at $30^{\circ} \mathrm{C}$ and operated with a hydraulic retention time (HRT) of $18 \mathrm{~h}$. It was possible to note that the four tested reactors were able to remove organic matter (higher than 84\%) and LAS (higher than 81\%), respectively, to initial mean value of $550 \mathrm{mg} / \mathrm{L}$ and $16.5 \mathrm{mg} / \mathrm{L}$. However, activated charcoal and expanded clay both produced shearing during reactor operation. Thus, sand was the chosen material to fill the bench scale reacto because of good results of LAS removal (99\%) and smaller cost and affordability compared to glass beads. After 270 days of operation, with crescent LAS concentrations and average of $32,3 \mathrm{mg} / \mathrm{L}$, it was found that the bench scale reactor was able to remove LAS in 93\%. All supports adsorb a few LAS (maximun of $0.43 \mathrm{mg}_{\mathrm{LAS}} / \mathrm{g}_{\text {clay }}$ ). This value does not interfere in biologic removal process. Microscopic tests done during the reactor's operation presented microorganisms with morphologies similar to spirochetes, bacillus, filamentous, cocci and others. 16S rRNA gene sequencing and phylogenetic analysis of samples from the bench scale reactor and smaller reactor filled with glass beads (R3) and sand (R4) revealed that these reactors gave rise to broad microbial diversity, with microorganisms belonging to the phyla Bacteroidetes, Proteobacteria, Verrucomicrobia and Firmicutes, and others.
\end{abstract}

Keywords: Sand. Expanded Clay. Activated Charcoal. Glass Beads. Fluidized Bed Reactor. Anaerobic Degradation. Surfactant. LAS. Gene 16S RNAr. 


\section{LISTA DE ILUSTRAÇÕES}

Figura 3.1: (a) Disposição das moléculas do agente surfactante antes de atingir a concentração micelar crítica; (b) Micela de surfactante em meio aquoso...................................................5

Figura 3.2: Estrutura do alquilbenzeno linear sulfonato.................................................... 6

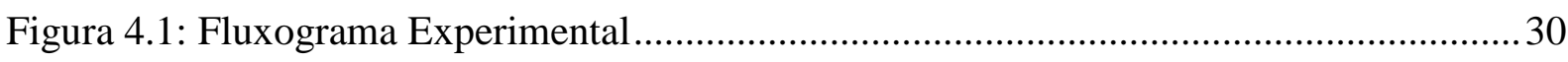

Figura 4.2: Fluxograma experimental da operação do reator................................................. 31

Figura 4.3: Fluxograma experimental dos ensaios de adsorção ........................................... 35

Figura 4.4: Diagrama esquemático da operação do reator de leito fluidificado........................ 39

Figura 4.5: Exemplo de cromatograma de LAS - padrão $30 \mathrm{mg} / \mathrm{L}$........................................ 42

Figura 4.6: Curva de calibração de LAS para cada um dos quatro picos do cromatograma.... 42

Figura 4.7: Esquema das diluições e inoculações do método NMP ........................................47

Figura 5.1: Variação da concentração de LAS ao longo do tempo em ensaios de adsorção em

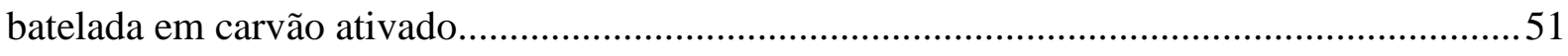

Figura 5.2: Variação da concentração de LAS ao longo do tempo em ensaios de adsorção em

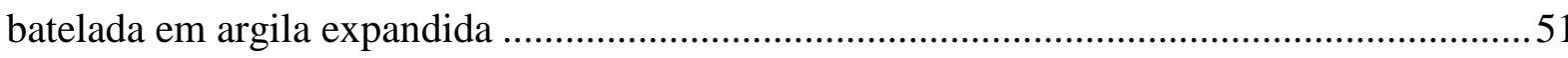

Figura 5.3: Variação da concentração de LAS ao longo do tempo em ensaios de adsorção em batelada em pérolas de vidro

Figura 5.4: Variação da concentração de LAS ao longo do tempo em ensaios de adsorção em batelada em areia

Figura 5.5: Curva característica de fluidificação para determinação gráfica da velocidade mínima de fluidificação experimental das pérolas de vidro

Figura 5.6: Curva característica de fluidificação para determinação gráfica da velocidade mínima de fluidificação experimental do carvão ativado

Figura 5.7: Curva característica de fluidificação para determinação gráfica da velocidade mínima de fluidificação experimental da argila expandida

Figura 5.8: Microscopia óptica de contraste de fase das morfologias observadas no inóculo:

(a) cocos, (b) bacilos retos e bacilos curvos

Figura 5.9: Variação temporal da DQO filtrada (etapa I).

Figura 5.10: Variação temporal da DQO filtrada (etapa IV)

Figura 5.11: Variação temporal da DQO filtrada afluente e efluente e eficiência de remoção em R1 (carvão ativado) 
Figura 5.12: Variação temporal da DQO filtrada afluente e efluente e eficiência de remoção em R2 (argila expandida)

Figura 5.13: Variação temporal da DQO filtrada afluente e efluente e eficiência de remoção em R3 (pérolas de vidro)

Figura 5.14: Variação temporal da DQO filtrada afluente e efluente e eficiência de remoção

em R4 (areia)

Figura 5.15: Variação temporal do pH afluente e efluente em R1 (carvão ativado).

Figura 5.16: Variação temporal do pH afluente e efluente em R2 (argila expandida)..... 65

Figura 5.17: Variação temporal do pH afluente e efluente em R3 (pérolas de vidro). 66

Figura 5.18: Variação temporal do pH afluente e efluente em R4 (areia).....

Figura 5.19: Variação temporal da alcalinidade parcial e total afluente e efluente em R1 (carvão ativado)

Figura 5.20: Variação temporal da alcalinidade parcial e total afluente e efluente em R2 (argila expandida)

Figura 5.21: Variação temporal da alcalinidade parcial e total afluente e efluente em R3 (pérolas de vidro).

Figura 5.22: Variação temporal da alcalinidade parcial e total afluente e efluente em R4 (areia)

Figura 5.23: Variação temporal da alcalinidade a bicarbonato efluente em R1 (carvão ativado)

e R2 (argila expandida)

Figura 5.24: Variação temporal da alcalinidade a bicarbonato efluente em R3 (pérolas de vidro) e R4 (areia).

Figura 5.25: Variação temporal de ácidos voláteis totais efluente em R1 (carvão ativado) e R2 (argila expandida)

Figura 5.26: Variação temporal de ácidos voláteis totais efluente em R3 (pérolas de vidro) e

R4 (areia)

Figura 5.27: Variação temporal da concentração de LAS afluente e efluente em R1 (carvão

ativado)

Figura 5.28: Variação temporal da concentração de LAS afluente e efluente em R2 (argila expandida)

Figura 5.29: Variação temporal da concentração de LAS afluente e efluente em R3 (pérolas de vidro) .73

Figura 5.30: Variação temporal da concentração de LAS afluente e efluente em R4 (areia) .. 74 
Figura 5.31: Valores de massas afluente e efluente e porcentagem de remoção de LAS em reatores em menor escala.

Figura 5.32: Variação temporal da DQO filtrada durante a inoculação do reator de leito fluidificado

Figura 5.33: Variação temporal da DQO filtrada afluente e efluente e eficiência de remoção 81

Figura 5.34: Variação temporal da concentração de LAS afluente e efluente 81

Figura 5.35: Variação temporal do pH afluente e efluente 86

Figura 5.36: Variação temporal da alcalinidade parcial afluente e efluente .86

Figura 5.37: Variação temporal da alcalinidade total afluente e efluente .87

Figura 5.38: Variação temporal da alcalinidade a bicarbonato efluente 87

Figura 5.39: Variação temporal de ácidos voláteis totais efluente 88

Figura 5.40: Microscopia de contraste de fase das morfologias observadas em R3 e R4: (a) e (b) bacilos, (c) cocos, (d) endósporos 90

Figura 5.41: Microscopia de contraste de fase das morfologias observadas no reator em escala de bancada após Etapa III: (a) espiroquetas, (b) bacilos, (c) sarcinas, (d) cisto 91 Figura 5.42: Microscopia de contraste de fase das morfologias observadas no reator em escala de bancada após Etapa V: (a) e (b) cocos, (c) espiroqueta, (d) bacilos 92 Figura 5.43: Microscopia de contraste de fase das morfologias observadas no reator em escala de bancada ao final da operação: (a) bacilos retos e curvos, (b) cocos, (c) filamentosas, (d) espiroqueta, (e) bacilos fluorescentes .93

Figura 5.44: Microscopia eletrônica de varredura das morfologias observadas no reator em escala de bancada ao final da operação: (a) bacilos (b) bacilos e exopolímero (aumento $5000 \mathrm{X})$

Figura 5.45: Porcentagem de clones dos reatores preenchido com pérolas de vidro (R3) e areia (R4) relacionados aos diferentes Filos. 96

Figura 5.46: Porcentagem de clones dos reatores preenchido com pérolas de vidro (R3) e areia (R4) relacionados às diferentes Classes.

Figura 5.47: Árvore filogenética do reator R3 (pérolas de vidro) mostrando a posição dos clones derivados das sequências do RNAr 16S. Eschericha coli foi usada como grupo externo. A taxa de substituição a cada 100 nucleotídeos foi de 0,2 como indicado na barra de escala.

Figura 5.48: Árvore filogenética 1 do reator R4 (areia) mostrando a posição dos clones derivados das sequências do RNAr 16S. Eschericha coli foi usada como grupo externo. A taxa de substituição a cada 100 nucleotídeos foi de 0,2 como indicado na barra de escala. 
Figura 5.49: Árvore filogenética 2 do reator R4 (areia) mostrando a posição dos clones derivados das sequências do RNAr 16S. Eschericha coli foi usada como grupo externo. A taxa de substituição a cada 100 nucleotídeos foi de 0,1 como indicado na barra de escala............ 108 Figura 5.50: Porcentagem de clones relacionada aos diferentes Filos ................................. 113 Figura 5.51: Porcentagem de clones relacionada às diferentes Classes ................................ 114 Figura 5.52: Árvore Filogenética do reator em escala de bancada mostrando a posição dos clones derivados das sequências do RNAr 16S relacionados a Classe Sphingobacteria.

Eschericha coli foi usada como grupo externo. A taxa de substituição a cada 100 nucleotídeos foi de 0,2 como indicado na barra de escala.

Figura 5.53: Árvore Filogenética do reator em escala de bancada mostrando a posição dos clones derivados das sequências do RNAr 16S relacionados a Classe Alphaproteobacteria. Eschericha coli foi usada como grupo externo. A taxa de substituição a cada 100 nucleotídeos foi de 0,2 como indicado na barra de escala.

Figura 5.54:Árvore Filogenética do reator em escala de bancada mostrando a posição dos clones derivados das sequências do RNAr 16S relacionados a Classe Betaproteobacteria. Eschericha coli foi usada como grupo externo. A taxa de substituição a cada 100 nucleotídeos foi de 0,2 como indicado na barra de escala.

Figura 5.55: Quantificação dos grupos microbianos pelo NMP 126

Figura 5.56: Reator de Leito Fluidificado alimentado com resarzurina para constatação de anaerobiose no sistema 


\section{LISTA DE TABELAS}

Tabela 3.1: Concentração de LAS após passar por estação de tratamento de esgoto (lodos ativados)

Tabela 3.2: Quadro resumo dos trabalhos sobre degradação anaeróbia de LAS

Tabela 4.1: Características do material suporte usado no reator anaeróbio de leito fluidificado em menor escala .

Tabela 4.2: Características do material suporte usado reator anaeróbio de leito fluidificado em escala de bancada

Tabela 4.3: Composição do substrato sintético 37

Tabela 4.4: Composição da solução de sais do substrato sintético 38

Tabela 4.5: Etapas de operação

Tabela 4.6: Etapas de operação do reator em escala de bancada 40

Tabela 4.7: Análises para monitoramento do reator de leito fluidificado 41

Tabela 4.8: Condições cromatográficas para quantificação do LAS comercial..... 41

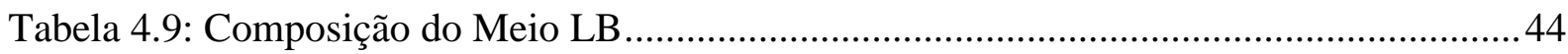

Tabela 5.1: Concentração média de LAS na fase líquida ao longo do tempo ..........................50

Tabela 5.2: Balanço de massa de LAS em ensaio de adsorção ...............................................53

Tabela 5.3: Resultados do ensaio de adsorção ....................................................................54

Tabela 5.4: Valores calculados para determinação da velocidade mínima de fluidificação das pérolas de vidro

Tabela 5.5: Valores calculados para determinação da velocidade mínima de fluidificação do carvão ativado

Tabela 5.6: Valores calculados para determinação da velocidade mínima de fluidificação da argila expandida.

Tabela 5.7: Valores dos parâmetros físico-químicos do afluente e efluente dos reatores de leito fluidificado durante etapas II e V .....

Tabela 5.8: Valores dos parâmetros físico-químicos do afluente e efluente dos reatores de leito fluidificado durante etapas III e VI

Tabela 5.9: Valores da concentração de LAS, sulfato e sulfeto afluente e efluente dos reatores

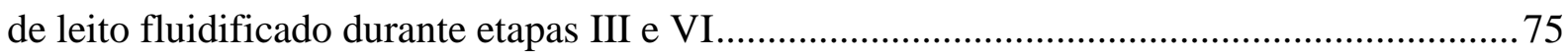

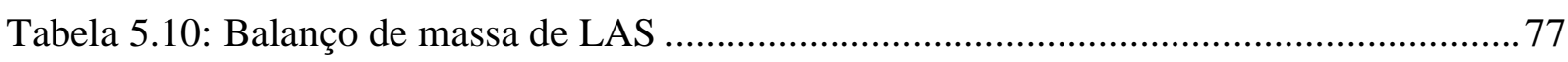

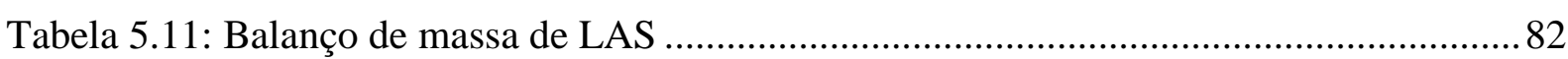


Tabela 5.12: Valores dos parâmetros físico-químicos afluente e efluente do reator de leito fluidificado durante as etapas de operação

Tabela 5.13: Concentração de LAS, sulfato e sulfeto afluente e efluente durante etapas II a VI

Tabela 5.14: Morfologias observadas em microscopia de contraste de fase e fluorescência... 94 Tabela 5.15: Clones do reator R3 (pérolas de vidro) classificados em Unidades Taxonômicas Operacionais (UTOs)

Tabela 5.16: Clones do reator R4 (areia) classificados em Unidades Taxonômicas Operacionais (UTOs)

Tabela 5.17: Sequências obtidas no Genbank relacionadas aos clones da amostra do reator R3 (pérolas de vidro). 109

Tabela 5.18: Sequências obtidas no Genbank relacionadas aos clones da amostra do reator R4 (areia) 111

Tabela 5.19: Clones classificados em Unidades Taxonômicas Operacionais (UTOs) 117

Tabela 5.20: Sequências obtidas no GenBank relacionadas aos clones das amostras do reator em escala de bancada. 


\section{LISTA DE ABREVIATURAS E SIGLAS}

AB alcalinidade a bicarbonato

ABNT

AGV

AOX

AP

ASBR

AT

AVT

BRS

CAG

CAP

$\mathrm{CMC}$

CSTR

DBO

DGGE

DNA

DQO

ETE

$\mathrm{HF}$

HPLC

LAS

LPB

MEV

NCBI

NMP

PCR

PET

POA

PVC
Associação Brasileira de Normas Técnicas

ácidos graxos voláteis

halogênios organicamente ligados

alcalinidade parcial

reator operado em bateladas sequenciais (anaerobic sequencing batch reactor)

alcalinidade total

ácidos voláteis totais

bactérias redutoras de sulfato

carvão ativado granular

carvão ativado em pó

concentração micelar crítica

reator contínuo de mistura completa (continuous stirred tank reactor)

demanda bioquímica de oxigênio

eletroforese em gel de gradiente desnaturante (denaturing gradient gel elecrophoresis)

ácido desoxirribonucléico

demanda química de oxigênio

estação de tratamento de esgoto

ácido fluorídrico

cromatografia líquida de alta eficiência (high performance liquid chromatography)

alquilbenzeno linear sulfonado (linear alkylbenzene sulfonate)

laboratório de processos biológicos

microscopia eletrônica de varredura

National Center for Biotechnology Information

número mais provável

reação em cadeia da polimerase (polymerase chain reaction)

poliestireno

processo de oxidação avançada

cloreto de polivinila 


$\begin{array}{ll}\text { R1 } & \text { reator 1 } \\ \text { R2 } & \text { reator 2 } \\ \text { R3 } & \text { reator 3 } \\ \text { R4 } & \text { reator 4 }\end{array}$

RAHLF reator anaeróbio horizontal de leito fixo

RALF reator anaeróbio de leito fluidificado

RNAr ácido ribonucléico ribossomal

SA surfactante aniônico

SPC sulfofenil carboxilato (sulphophenyl carboxylate)

ST sólidos totais

STF sólidos totais fixos

STV sólidos totais voláteis

TDH tempo de detenção hidráulica

UASB fluxo ascendente e manta de lodo (upflow anaerobic sludge blanket)

UNESP Universidade Estadual Paulista

UTO unidade taxonômica operacional 


\section{LISTA DE SÍMBOLOS}

$\begin{array}{lll}\mathrm{V} & \text { velocidade ascencional } & (\mathrm{cm} / \mathrm{s}) \\ \mathrm{Q} & \text { vazão } & \left(\mathrm{cm}^{3} / \mathrm{s}\right) \\ \mathrm{A} & \text { área } & \left(\mathrm{cm}^{2}\right) \\ \mathrm{P} & \text { pressão } & \left(\mathrm{g} / \mathrm{cm}^{2} \mathrm{~s}^{2}\right) \\ \rho & \text { densidade } & \left(\mathrm{g} / \mathrm{cm}^{3}\right) \\ \mathrm{g} & \text { aceleração da gravidade } & \left(\mathrm{cm} / \mathrm{s}^{2}\right) \\ \mathrm{h} & \text { altura } & (\mathrm{cm})\end{array}$




\section{SUMÁRIO}

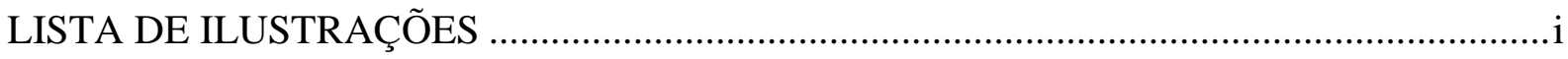

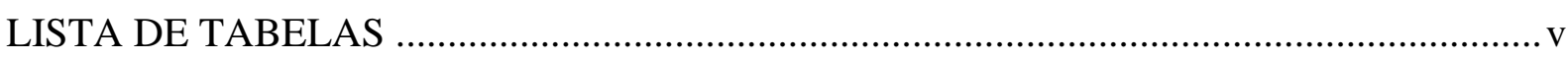

LISTA DE ABREVIATURAS E SIGLAS …................................................................. vii

LISTA DE SÍMBOLOS ..............................................................................................

1. INTRODUÇÃ

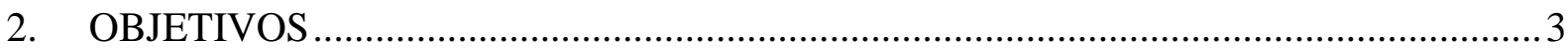

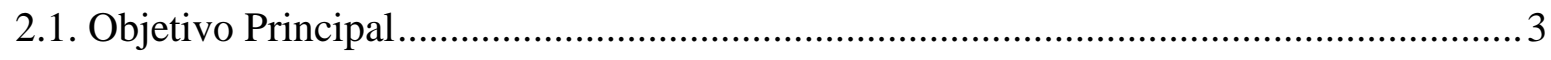

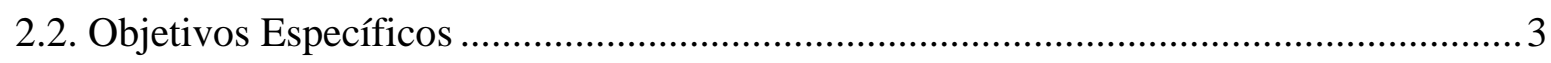

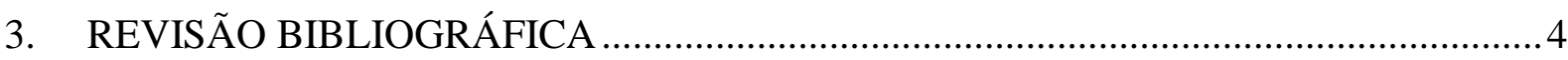

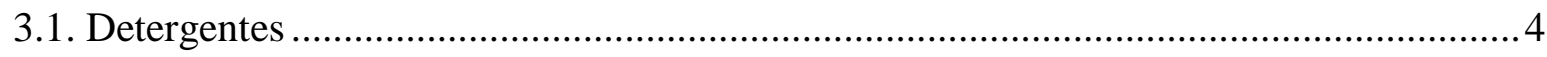

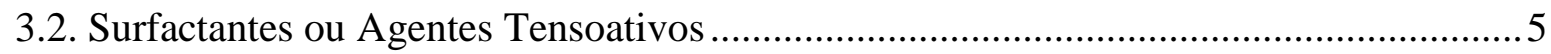

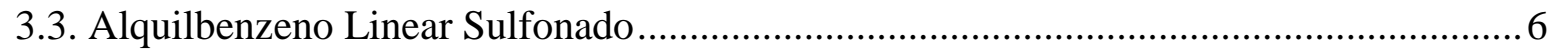

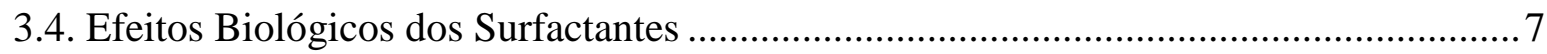

3.5. Remoção de Surfactantes de Águas Residuárias .........................................................

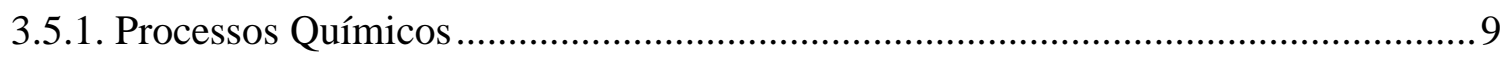

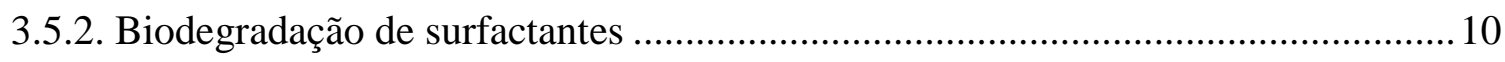

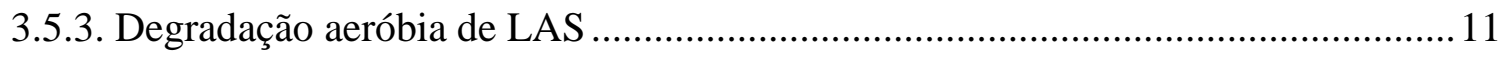

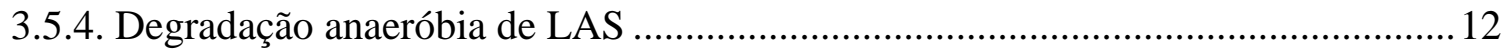

3.6. Material Suporte para Imobilização da Biomassa ......................................................... 18

3.7. Reatores Anaeróbios com Biomassa Imobilizada .......................................................... 21

3.8. Reator de Leito Fluidificado .................................................................................... 23

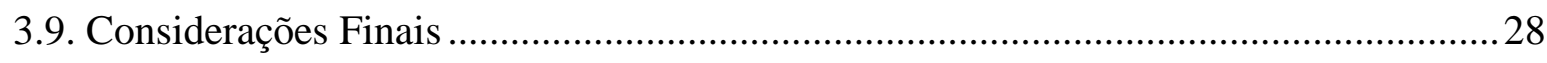

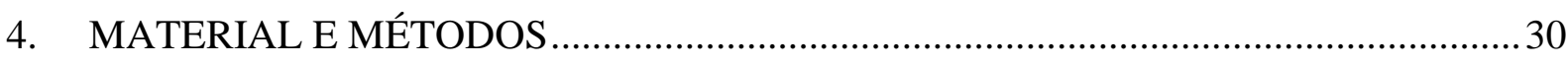

4.2. Caracterização do Material Suporte …..................................................................... 32

4.2.1 Determinação da Velocidade Mínima de Fluidificação ............................................33

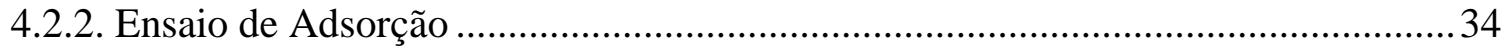

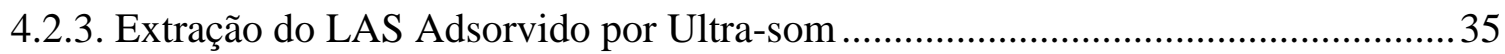

4.2.4. Determinação da Eficiência do Método de Extração ............................................. 36

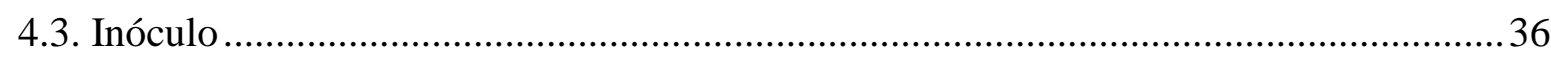

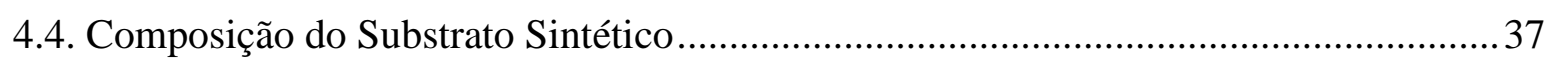

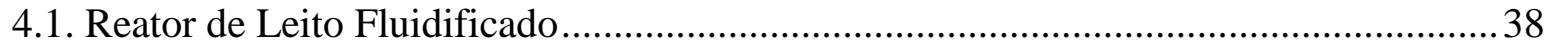

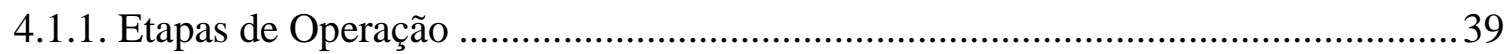


4. 5. Análises Físico-Químicas e Cromatográficas................................................................ 41

4.6. Caracterização da diversidade Microbiana............................................................... 43

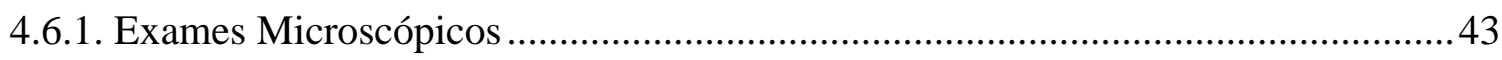

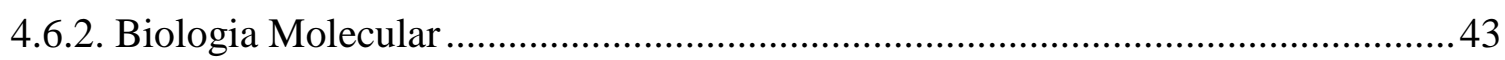

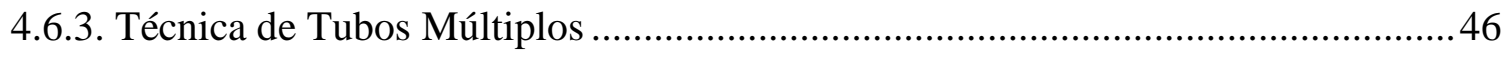

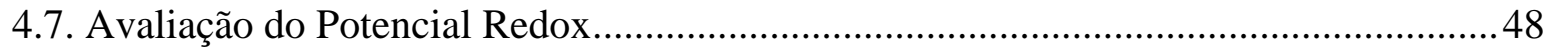

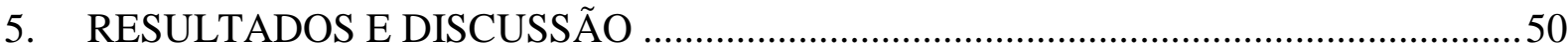

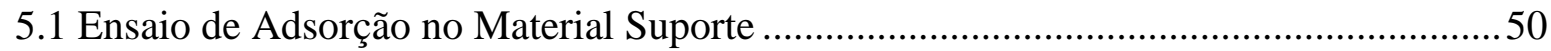

5.2 Eficiência do Método de Extração................................................................................. 54

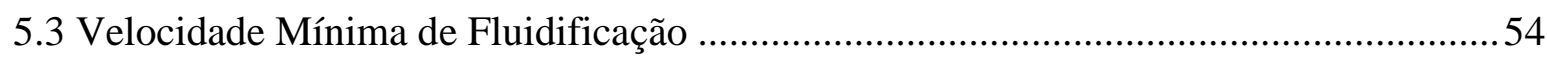

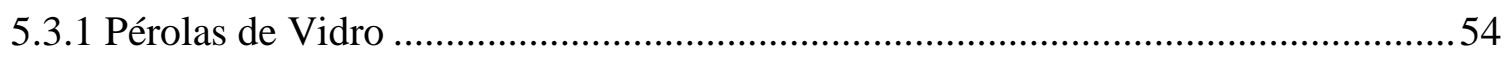

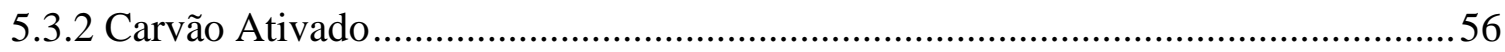

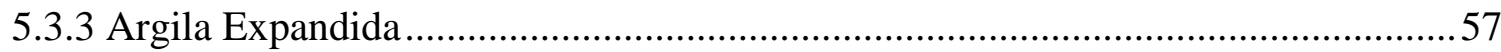

5.4. Operação e Monitoramento dos Reatores Anaeróbios de Leito Fluidificado em Menor

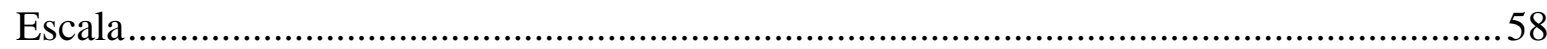

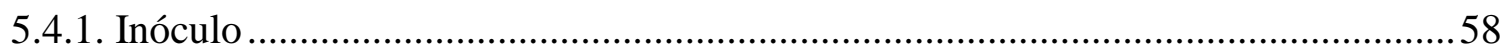

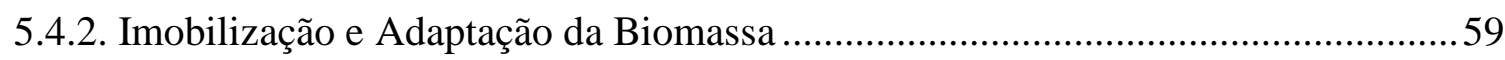

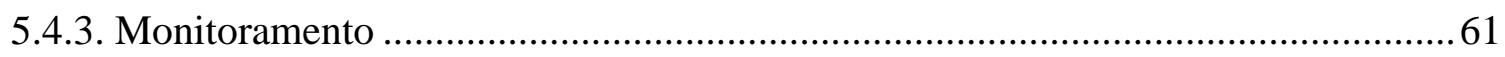

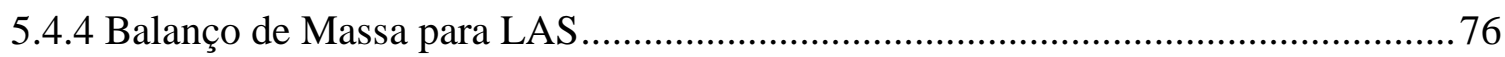

5.5. Operação e Monitoramento do Reator Anaeróbio de Leito Fluidificado em Escala de

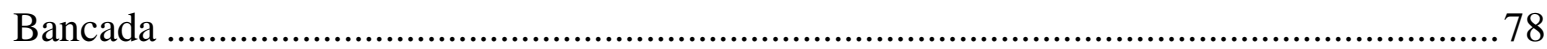

5.5.1. Remoção de Matéria Orgânica e LAS ..................................................................... 79

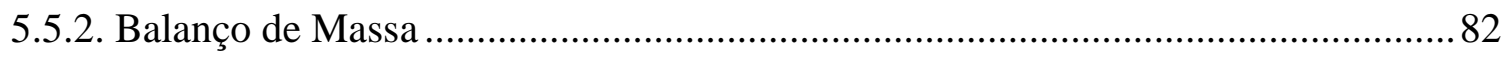

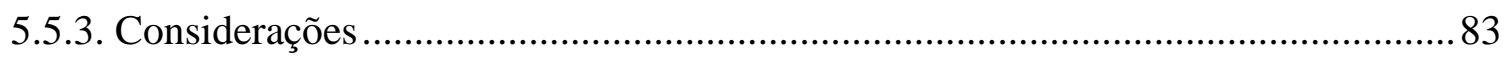

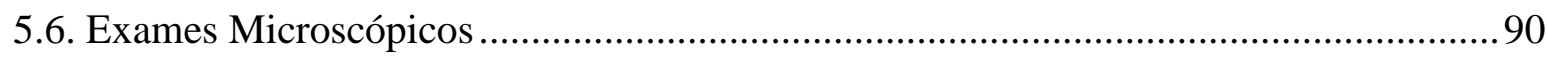

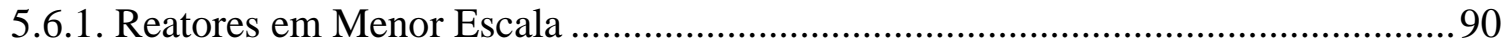

5.6.2. Reator em Escala de bancada ............................................................................... 91

5.7. Caracterização filogenética do Domínio Bacteria ........................................................95

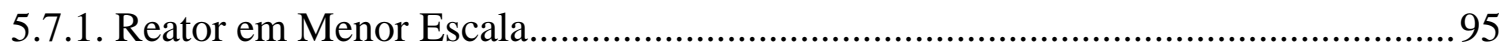

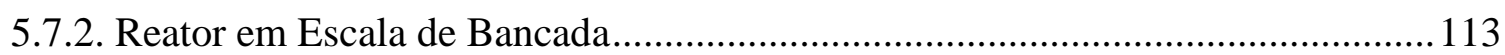

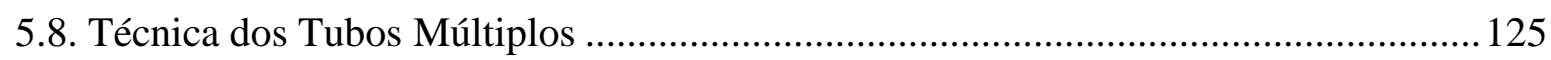

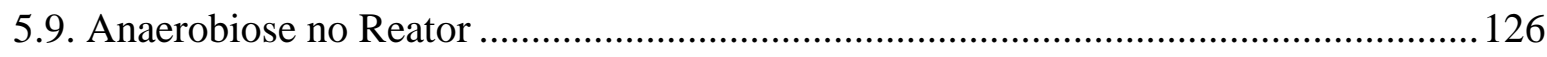

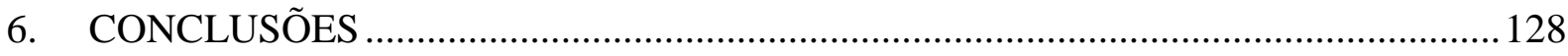

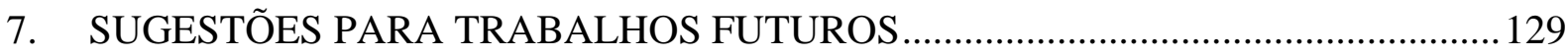




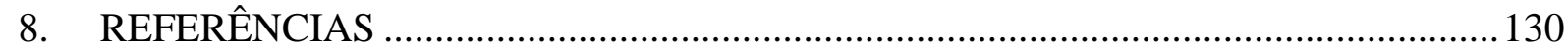

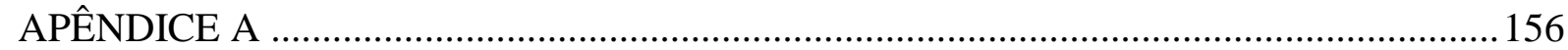




\section{INTRODUÇÃO}

Alquilbenzeno Linear Sulfonado (LAS) é o surfactante aniônico mais utilizado mundialmente na formulação de detergentes e encontra-se presente em esgoto sanitário e águas residuárias industriais. Sua presença em estações de tratamento de esgoto pode gerar problemas como formação de espuma e inibição dos microrganismos responsáveis pelo processo de tratamento biológico.

A degradação do LAS em sistemas de tratamento aeróbio vem sendo bastante estudada. Eficiências de remoção de até $97 \%$ foram observadas em estações de tratamento de esgoto com lodos ativados (SCOTT E JONES, 2000). Essa remoção de LAS deve-se, provavelmente, aos fenômenos de degradação e adsorção no lodo biológico. São, ainda, poucos os estudos sobre a degradação do LAS em condições anaeróbias.

Trabalhos em reatores anaeróbios horizontais de leito fixo com biomassa imobilizada em diferentes materiais suporte (espuma de poliuretano, carvão vegetal, argila expandida) obtiveram remoção de até $35 \%$ de LAS em concentração inicial de aproximadamente $14 \mathrm{mg} / \mathrm{L}$ (DUARTE et al., 2008 e 2009; OLIVEIRA et al., 2009). Além disso, análises microbiológicas mostraram que bactérias redutoras de sulftato estiveram presentes nos reatores indicando possível participação desses microrganismos na degradação do composto.

Assim, a motivação desse trabalho residiu na possibilidade de avaliar a degradação do LAS em reator anaeróbio de leito fluidificado. Tal tecnologia ainda não foi estudada para remoção de detergente e tem se mostrado bastante eficiente no tratamento de águas residuárias simples e complexas. O sistema de mistura do reator pode facilitar a transferência de massa e, então, aumentar a disponibilidade do surfactante para os microrganismos, aumentando a eficiência de remoção quando comparado a outras configurações de reator, tais como, UASB e leito fixo.

O reator anaeróbio de leito fluidificado vem sendo estudado com sucesso na degradação de águas residuárias simples de baixa concentração como esgoto doméstico e outras mais complexas contendo, por exemplo, fenol ou vinhaça. Este sistema, com biomassa imobilizada em material suporte, favorece a retenção de microrganismos e alcança elevadas eficiências com baixos tempos de detenção hidráulica. Pesquisas utilizando este reator mostraram que diversos compostos tóxicos podem ser degradados e vários materiais suporte podem ser usados para imobilização da biomassa. 
Todavia, a degradação de LAS em reator anaeróbio de leito fluidificado ainda não foi estudada. Pretendeu-se, então, através da utilização de diferentes materiais suporte, da melhor transferência de massa e da diluição da alimentação devido à recirculação existentes no sistema de leito fluidificado, permitir maior contato dos microrganismos com o surfactante e, assim, obter porcentagens de remoção maiores do que as obtidas até agora em trabalhos de degradação anaeróbia de LAS.

Outro fator importante sobre a degradação de LAS é que as comunidades microbianas presentes em reatores anaeróbios capazes de degradar surfactante não estão amplamente caracterizadas. Apenas alguns trabalhos recentes apresentam resultados nessa área. Assim, o presente trabalho também investigou os microrganismos envolvidos na degradação do LAS por meio de técnicas de Biologia Molecular. 


\section{OBJETIVOS}

\subsection{Objetivo Principal}

O principal objetivo desse trabalho foi avaliar a remoção do LAS em reator anaeróbio de leito fluidificado preenchido com biomassa imobilizada em diferentes materiais suporte.

\subsection{Objetivos Específicos}

Os objetivos específicos desse trabalho foram:

Determinar o suporte de imobilização de biomassa mais adequado na remoção de LAS entre, carvão ativado, argila expandida, pérolas de vidro e areia;

Determinar o potencial adsorvente dos materiais suporte;

$>$ Verificar a eficiência de remoção de matéria orgânica e LAS nas fases de operação do reator de leito fluidificado em escala de bancada;

Avaliar e caracterizar a comunidade microbiana do biofilme desenvolvido no material suporte dos reatores anaeróbios de leito fluidificado. 


\section{REVISÃO BIBLIOGRÁFICA}

A possível contaminação do ambiente por surfactantes devido ao uso muito difundido de detergentes tem sido, atualmente, objeto de estudos. Um dos surfactantes mais utilizados é o LAS (alquilbenzeno linear sulfonado). Esse surfactante está presente em estações de tratamento de água residuária onde é parcialmente degradado aerobiamente e parcialmente adsorvido no lodo que será disposto no solo ou em aterros sanitários. A sua biodegradação em sistemas de tratamento de água residuária, e posterior descarga em águas naturais, além da aplicação do lodo resultante em solo, têm sido muito pesquisadas.

\subsection{Detergentes}

Detergentes são misturas de substâncias que possuem propriedades de limpeza ou solubilização. De acordo com Borsato et al. (1999), o sabão, existente desde o século XXV a.C. em nossa civilização, foi o primeiro detergente utilizado.

$\mathrm{Na}$ composição dos detergentes estão presentes agentes tensoativos que alteram as propriedades da superfície e da interface das soluções aquosas. Todos os agentes tensoativos têm uma característica em comum, possuem uma parte da molécula hidrofílica e outra parte hidrofóbica.

Quando o agente tensoativo entra em contato com a água, tende a ocupar a superfície do sistema. A parte hidrofílica fica voltada para a solução e a parte hidrofóbica para o ar (Figura 3.1a). Esta disposição provoca diminuição da tensão superficial da água. Aumentando-se a concentração do agente tensoativo, este tende a ocupar a parte interna da solução, formando inicialmente dímeros, trímeros, tetrâmeros, até que em determinada concentração, forma micelas (Figura 3.1b).

Esta concentração é denominada concentração micelar crítica (CMC), característica a cada agente tensoativo e dependente da temperatura e da composição da solução aquosa. A partir da concentração crítica manifesta-se a ação detergente.

Os agentes tensoativos, também chamados surfactantes, podem ser classificados quanto aos radicais hidrofílicos em aniônicos - apresentam em sua constituição carga negativa; catiônicos - possuem carga positiva; não-iônicos - não apresentam nenhuma carga em suas moléculas e anfóteros - possuem em sua estrutura um átomo de nitrogênio com carga positiva (BORSATO et al., 1999). 


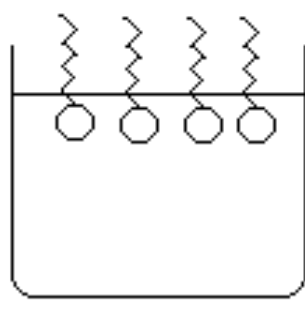

(a)

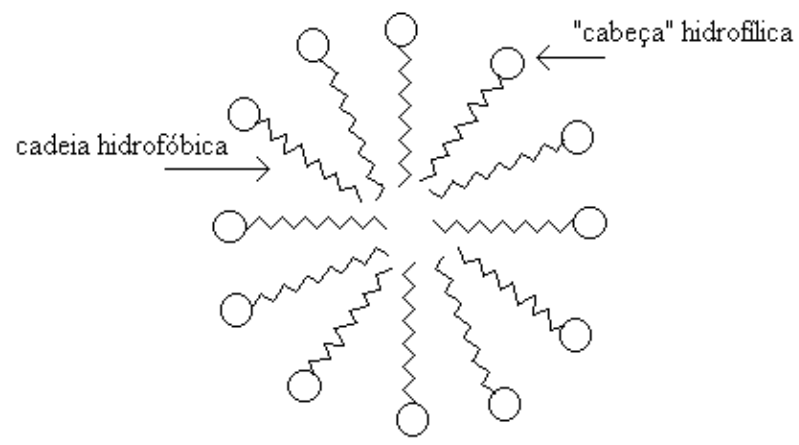

(b)

Figura 3.1: (a) Disposição das moléculas do agente surfactante antes de atingir a concentração micelar crítica; (b) Micela de surfactante em meio aquoso.

Fonte: BORSATO, et al., 1999.

\subsection{Surfactantes ou Agentes Tensoativos}

Surfactantes são amplamente usados em produto de limpeza doméstica e industrial. Após o uso são enviados a estações de tratamento e, então, descartados no ambiente através da descarga do efluente em águas superficiais. Geralmente, o lodo proveniente do descarte da biomassa dos reatores de tratamento é disposto no solo ou em aterros. Devido ao uso generalizado e elevado consumo, surfactantes e seus produtos de degradação têm sido detectados em várias concentrações em águas superficiais, sedimentos de rios e solos (Tabela 3.1). Segundo, Di Corcia, em 1998 a produção mundial de surfactantes foi de 7,2 milhões de toneladas.

Tabela 3.1: Concentração de LAS após passar por estação de tratamento de esgoto (lodos ativados)

\begin{tabular}{ccc}
\hline Amostra & Concentração & Referência \\
\hline Efluente & $1,09 \mathrm{mg} / \mathrm{L}$ & HOLT et al., 1998 \\
Lodo & $30.200 \mathrm{mg} / \mathrm{kg}$ & BERNA et al., 1989 \\
\hline
\end{tabular}

Os surfactantes têm diferentes comportamentos e destinos no ambiente. Os catiônicos e não iônicos têm maior adsorção em solo e sedimentos do que os aniônicos, tais como, LAS (YING, G.-G., 2006). 


\subsection{Alquilbenzeno Linear Sulfonado}

Surfactantes aniônicos (SA) são compostos anfipáticos que consistem de uma parte hidrofóbica (cadeia alquílica de vários comprimentos) e uma parte hidrofílica (carboxil, sulfato, sulfonado, fosfatos, etc.) (MUNGRAY e KUMAR, 2008).

O alquilbenzeno linear sulfonado (LAS) é um surfactante aniônico que foi introduzido no mercado em 1964, com a finalidade de substituir o tetrapropilbenzeno sulfonado que apresenta longa cadeia carbônica com ramificações.

O LAS comercial é geralmente composto por uma mistura de vários homólogos (cadeias carbônicas de diferentes comprimentos $-\mathrm{C}_{10}-\mathrm{C}_{14}$ ). Cada homólogo contém um anel aromático sulfonado na posição -para ligado à cadeia linear alquil em qualquer posição, exceto aos carbonos terminais, como mostra a Figura 3.2 (MATTHIJS e DE HENAU, 1987).

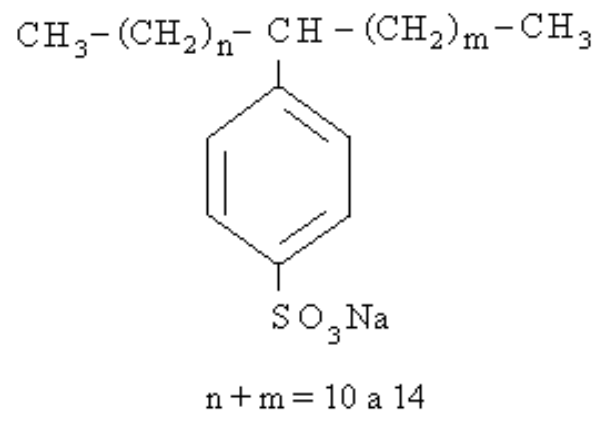

Figura 3.2: Estrutura do alquilbenzeno linear sulfonato

A presença de LAS em águas residuárias é proveniente de atividades domésticas (1 a $22 \mathrm{mg} / \mathrm{L}$ ) e pode variar, de acordo com seu uso, em processos industriais (SCOTT e JONES, 2000). Atualmente, o LAS representa mais de $40 \%$ de todo o surfactante utilizado no mundo. Estima-se que seu consumo mundial em 2000 foi em torno de 2,5 milhões de toneladas (SANZ et al., 2003). Dessa maneira, especial atenção deve ser dada a sua ocorrência e destino no ambiente. Esse surfactante é geralmente considerado biodegradável e sua remoção de águas residuárias tem se restringido a tratamentos biológicos convencionais (MANOUSAKI et al., 2004).

Níveis típicos de LAS em lodo de digestores aeróbios são encontrados entre 100 e $500 \mathrm{mg} / \mathrm{kg}$ massa seca. Em contrapartida, lodos de digestores anaeróbios podem conter em média 5.000 e $15.000 \mathrm{mg} / \mathrm{kg}$ massa seca (MUNGRAY e KUMAR, 2008). O lodo granulado de reator UASB fornece grande área superficial para a adsorção do surfactante. 
O maior volume de surfactantes aniônicos é usado em produtos de consumo como detergentes para lavagens de roupas, agentes de limpeza e lavagem de louças, além de fração significativa incorporada aos produtos de cuidados pessoais (MUNGRAY e KUMAR, 2008). Após o uso, concentrações razoáveis de LAS são detectadas no corpo receptor, apesar de passarem por estações de tratamento de esgoto sanitário e água residuária (GARCIA, et al., 2009). Por exemplo, $98 \%$ de todo o LAS usado pela população foi removido em estações de tratamento de esgoto, sendo o restante descartado em ecossistemas aquáticos (ALVAREZMUÑOS, et al., 2009).

Alvarez-Muños, et al. (2009) determinaram a concentração de LAS e produtos intermediários da degradação, tais como, ácido sulfofenilcarboxilato (SPCs) em vários ecossistemas do litoral Ibérico. Os valores foram de algumas centenas de $\mu \mathrm{g} / \mathrm{L}$ de surfactante próximo a descarga das águas residuárias. A jusante, as concentrações de LAS e, também de SPCs, diminuíram devido à diluição, adsorção-precipitação e degradação.

Aplicação de lodo proveniente de estação de tratamento de esgoto no solo é a fonte mais significante de surfactantes aniônicos em ambientes terrestres. Graças à ação dos microrganismos aeróbios presentes no solo, a degradação ocorre rapidamente. Knaebel, et al. (1990) estudaram 11 solos diferentes e obtiveram meia vida de dois dias para concentração de surfactante de $2 \mathrm{ng} / \mathrm{g}_{\text {solo }}$

No entanto, existem efeitos de curto prazo em solos usados na agricultura que foram alterados por lodo de esgoto contendo LAS. Foi sugerido que o LAS tem potencial para inibir a atividade biológica. LAS em concentração maior que $40-60 \mathrm{mg} / \mathrm{kg}$ massa seca pode ter efeito tóxico na reprodução e crescimento de invertebrados do solo. Minhocas e "enchydracids" foram quatro vezes mais sensíveis ao LAS que colêmbolos e ácaros (MUNGRAY e KUMAR, 2008).

\subsection{Efeitos Biológicos dos Surfactantes}

Singh et al. (2002) avaliaram a toxicidade aguda de diferentes surfactantes comumente usados: três aniônicos (SDS, SDBS e SDES), dois não iônicos (DHE e CTX) e dois catiônicos (CTAB e DTDMAC) para concentração de 1 a $100 \mathrm{mg} / \mathrm{L}$. Quatro espécies de peixes e duas de invertebrados foram escolhidos como organismos testes para estudos toxicológicos e foram classificados em ordem decrescente de peso e tamanho:

Salmo gairdneri $>$ Cirrhina $>$ Carassius $>$ Gambusia $>$ Gammarus $>$ Chironomus 
Dentre os sete surfactantes testados, os pesquisadores concluíram que o mais tóxico foi DTDMAC, enquanto, SDS foi menos tóxico. A ordem geral de toxicidade para todos os organismos vivos testados foi:

\section{DTDMAC $>$ CTAB $>$ SDBS $>$ CTX $>$ SDES $>$ DHE $>$ SDS}

Assim, quanto à toxicidade aquática, surfactantes catiônicos foram mais tóxicos que aniônicos e estes, por sua vez, mais tóxicos que não-iônicos, porém SDS foi uma exceção. CTX é não-iônico, porém foi mais tóxico que os aniônicos SDES e SDS, provavelmente devido a seu elevado peso molecular e presença do anel benzênico (SINGH et al., 2002).

Quanto ao tamanho da cadeia carbônica do surfactante, de maneira geral, a toxicidade do LAS aumenta com o tamanho da cadeia. Este fato se deve provavelmente a maior interação dos homólogos maiores com a membrana celular. Singh et al. (2002) também realizaram testes com os homólogos individuais do LAS em população microbiana presente em sistemas de tratamento de lodos ativados. A maior toxicidade foi verificada para $\mathrm{C}_{12}$-LAS dentre todos os homólogos testados $\left(\mathrm{C}_{10}-\mathrm{C}_{14}\right)$, como conseqüência do equilíbrio entre os processos de adsorção, precipitação e biodegradação. Para os homólogos $C_{10}, C_{11}$ e $C_{12}$, quanto menor o peso molecular, menor a toxicidade. Já entre os homólogos $\mathrm{C}_{12}, \mathrm{C}_{13}$ e $\mathrm{C}_{14} \mathrm{a}$ relação é oposta, ou seja, quanto maior o peso molecular, menor a toxicidade devido a elevada adsorção e menor biodisponibilidade dos homólogos maiores.

Nos últimos anos, o uso de biomarcadores sensíveis como ferramenta para monitorar qualidade ambiental e adaptação de organismos a ameaças ao ambiente, tem atraído muita atenção. Respostas celulares identificadas em diferentes organismos têm sido úteis para caracterizar a situação de saúde dos organismos, bem como para avaliar o impacto de parâmetros ambientais (ALVAREZ-MUÑOZ et al., 2009).

Tem sido demonstrado que a biotransformação ou metabolismo de compostos xenobióticos resulta na formação de espécies reativas de oxigênio. Essas espécies podem conduzir a danos oxidativos como, por exemplo, peroxidação lipídica, inativação enzimática, rompimento do DNA e ligação covalente para proteína e ácido nucléico. Células vivas têm mecanismos de defesa para neutralizar os efeitos nocivos dos radicais óxidos (ALVAREZMUÑOZ et al., 2009).

Dessa maneira, Alvarez-Muñoz e colaboradores (2009) estudaram o efeito da exposição de peixe Solea senegalensis a $26 \mathrm{mg} / \mathrm{L}$ de LAS. Os danos histopatológicos encontrados incluem fusão lamelar, elevação, e estagnação do sangue em brânquias, aumento do número de células nas mucosas e gotas lipídicas, descamação epitelial e perda do tecido do intestino. No entanto, essas são respostas das quais os organismos podem se recuperar. O 
correto funcionamento do sistema de defesa antioxidante na ausência de grandes variações, os danos histopatológicos a curto-prazo do qual cada organismo pode se recuperar, e a presença de SPCs, indicam metabolismo adequado do LAS por essas espécies, e efeitos não-tóxicos a nível ambientalmente real.

A diminuição da concentração de LAS nos peixes durante a fase de depuração é devido à biotransformação e excreção de metabólitos, e a eliminação difusiva do composto através de brânquias ou pele para a água. Após esse processo os metabólitos são excretados ativamente pela urina ou fezes, onde o trato digestivo tem papel importante.

\subsection{Remoção de Surfactantes de Águas Residuárias}

Diferentes métodos têm sido empregados para tratar surfactantes, como por exemplo, tratamento biológico, adsorção e oxidação avançada. Em processos de adsorção, lodo indesejável é produzido, que necessita de tratamento posterior. Tratamentos biológicos são mais econômicos quando comparados a outros métodos. Processos de oxidação avançada (POAs) são métodos promissores para tratamento de orgânicos não-biodegradáveis (DOAN e SAIDI, 2008).

\subsubsection{Processos Químicos}

Basar et al. (2004) estudaram a remoção de surfactantes em água residuária sintética através da adsorção por carvão ativado com área superficial de $465 \mathrm{~m}^{2} / \mathrm{g}$ e partículas de $30 \mu \mathrm{m}$, seguida de micro-filtração para separação de partículas. Foram estudados os seguintes surfactantes: (1) LAS (aniônico) e (2) CTAB, brometo de cetil trimetil amônio (catiônico) em processo contínuo com recirculação. O uso da microfiltração resultou em maior remoção de ambos os surfactantes quando comparada à remoção somente por adsorção. Durante a filtração formou-se uma segunda camada sobre a membrana que melhorou seu desempenho.

Vários fatores foram analisados tais como, concentração do surfactante, pressão na membrana e tamanho dos poros da membrana. Os autores concluíram que as micelas do surfactante, com tamanho menor que $20 \mathrm{~nm}$, também foram retidas na microfiltração devido à formação de uma camada sobre a membrana constituída pelo próprio surfactante. Variações na temperatura, entre 20 e $40^{\circ} \mathrm{C}$ não causaram alterações na eficiência da microfiltração

Íons de metais podem ser removidos de uma solução aquosa por eletrodeposição. Esta técnica tem reduzida produção de lodo, baixo custo de operação e nenhuma contaminação 
química da água tratada. Reações eletroquímicas podem ser efetuadas a pressão e temperatura ambiente e podem ser facilmente encerradas desconectando a corrente da célula (DOAN e SAIDI, 2008).

Para água contendo ambos, íons de metal e compostos orgânicos, uma célula eletrolítica pode somente remover íons de metal, mas pode não ser capaz de atingir a degradação completa do composto orgânico na água residuária. Assim, Doan e Saidi (2008) desenvolveram e avaliaram um método combinado fotocatalítico e eletroquímico para tratamento de água residuária de processo de revestimento elétrico, que contém metais pesados e compostos orgânicos, no caso, alquilbenzeno linear sulfonado (LAS).

No sistema fotocatalítico com partículas de $\mathrm{TiO}_{2}$ suspensas, o $\mathrm{pH}$ ótimo para degradação do LAS foi 5,0. Nesse pH, 60\% do LAS foi degradado após período de 7 horas. No entanto, para $\mathrm{TiO}_{2}$ imobilizado em partículas de sílica gel, LAS foi degradado somente em $31 \%$ devido a baixa relação entre a área de superfície ativa e o volume de líquido. No processo combinado eletroquímico-fotocatalítico com $\mathrm{TiO}_{2}$ suspenso, a remoção de LAS melhorou em $12 \%$ e $19 \%$ comparado com o tratamento fotocatalítico ( $\mathrm{pH} 5,0)$ e sem controle de $\mathrm{pH}$, respectivamente.

O sistema combinado usado por Doan e Saidi (2008) pode, desse modo, ser considerado uma possibilidade de tratamento de efluentes industriais contendo ambos, íons de metal e compostos orgânicos.

\subsubsection{Biodegradação de surfactantes}

A degradação de surfactantes através da atividade microbiana (biodegradação) é a primeira transformação a ocorrer no ambiente. É um processo importante para remover surfactantes presentes em águas residuárias em estações de tratamento de esgoto, e também aprimora a remoção destes compostos no ambiente, reduzindo assim, seu impacto na biota aquática e terrestre. Na biodegradação, os microrganismos podem utilizar os surfactantes como fonte de carbono, energia e nutrientes.

Existem muitos fatores químicos e ambientais que afetam a biodegradação de surfactantes. Os mais importantes são a estrutura química do surfactante e as condições físicoquímicas do meio. Diferentes surfactantes têm diferentes possibilidades de degradação no ambiente (YING, G-G, 2006). 
Devido à incompleta remoção de LAS em estações de tratamento de esgoto, alguns resíduos do surfactante juntamente com os intermediários de sua lise, como por exemplo, os carboxilados sulfofenílicos (SPC), entram no corpo receptor via descarga de efluentes. Concentrações de mais de 100 ppb foram encontradas em águas superficiais de rio da Espanha (ÁLVAREZ-MUÑOZ, et al., 2007). Concentrações maiores foram encontradas em amostras coletadas próximas a descarga de estações de tratamento de esgoto. As concentrações diminuiram para poucos ppb ao longo do rio como resultado da diluição, sorção, e degradação.

Trabalhos envolvendo a quantificação de detergentes em rios e reservatórios brasileiros ainda são escassos. Em trechos do rio Tietê, Pinheiros e represa Billings, mais acentuadamente nas descargas das barragens de Pirapora (rio Tietê) e Traição (rio Pinheiros) têm ocorrido elevada formação de espumas produzidas por detergentes. As espumas são ricas em material particulado e metais pesados como cobre, chumbo, níquel e cádmio (BARBIERI et al., 2000). Em São Paulo, a concentração de detergentes no rio Tamanduateí, em 1992, foi de 2,3 mg/L (CETESB, 1992) e no rio Tietê, na região de Pirapora, foi $1,6 \mathrm{mg} / \mathrm{L}$ (HATUMARA et al., 1993). No rio Macacu, Estado do Rio de Janeiro, foram encontradas concentrações de LAS e intermediários de sua degradação nas faixas de 14 a $155 \mu \mathrm{g} / \mathrm{L}$ e 1,2 a $14 \mu \mathrm{g} / \mathrm{L}$, respectivamente. A presença de intermediários da degradação indicou que a comunidade microbiana presente foi capaz de oxidar o LAS (EICHHORN et al., 2002).

\subsubsection{Degradação aeróbia de LAS}

Dentre as alternativas técnicas disponíveis para o tratamento de águas residuárias contendo compostos orgânicos, o tratamento biológico oferece melhores condições por apresentar custos relativamente baixos quando comparado ao tratamento físico-químico.

Culturas mistas de microrganismos encontradas no ambiente ou em estações de tratamento podem degradar o LAS por processo aeróbio (SCHÖBERL, 1989), em etapas definidas como biodegradação primária e final (SCOTT e JONES, 2000). Na biodegradação primária, a estrutura do composto muda o suficiente para a molécula perder suas propriedades surfactantes, enquanto que, na biodegradação final, ocorre a formação de gás carbônico $\left(\mathrm{CO}_{2}\right)$, água $\left(\mathrm{H}_{2} \mathrm{O}\right)$, sais minerais e biomassa.

Em determinadas condições, o LAS poderá manter-se na água mesmo após o tratamento biológico, principalmente devido à presença do anel aromático que é resistente à 
degradação. No entanto, porcentagens elevadas de remoção (acima de 97\%) foram obtidas em alguns sistemas de tratamento de águas residuárias utilizando processos aeróbios (BRUNNER et al., 1988).

Sob condições aeróbias, a degradação do LAS é realizada nos seguintes estágios:

(1) degradação da cadeia alquílica;

(2) degradação do grupo sulfonado;

(3) degradação do anel benzênico.

No primeiro estágio ocorre a oxidação do grupo metila terminal ( $\omega$-oxidação) a ácidos carboxílicos. Poderá então ocorrer a $\beta$-oxidação dos ácidos carboxílicos. Nesse momento, é importante considerar a extensão da cadeia alquílica. Caso a cadeia seja longa, provavelmente não ocorrerá a $\beta$-oxidação pela ação dos microrganismos e, conseqüentemente, poderá ser degradada perdendo um átomo de carbono por vez ( $\alpha$-oxidação).

Para o segundo estágio, três mecanismos foram propostos:

(1) dessulfonação hidroxidativa,

(2) catálise monooxigenase sob condições ácidas e

(3) dessulfonação redutiva.

A velocidade de degradação é mais rápida para homólogos de LAS com maior cadeia alquílica (por exemplo, 14 carbonos) e, dentre esses, mais lenta para isômeros que apresentam o grupo sulfofenil no meio da cadeia (SCOTT e JONES, 2000). Os autores sugeriram ainda a necessidade de relações sintróficas dos microrganismos aeróbios para degradação do surfactante. Provavelmente, alguns microrganismos oxidam a cadeia alquílica e outros participam da mineralização do anel aromático.

\subsubsection{Degradação anaeróbia de LAS}

Embora degradação anaeróbia de LAS tenha sido reportada (ALMENDARIZ, et al., 2001; SANZ, et al., 2003, DUARTE, et al., 2008 e 2009, OLIVEIRA, et al., 2009), as rotas metabólicas não são totalmente conhecidas. A limitada informação apenas indica as seguintes considerações:

(1) LAS pode ser usado como fonte de enxofre por bactérias anaeróbias sob condições limitadas de sulfato (DENGER e COOK, 1999); 
(2) Ácido benzenosulfônico e benzaldeído podem ser produzidos como metabólitos na degradação anaeróbia de LAS (MOGENSEN, et al., 2003);

(3) Benzeno e tolueno foram encontrados em efluente de reator anaeróbio usado na degradação de LAS (DUARTE, 2006).

Até o final da década de 90, acreditava-se que o LAS não podia ser degradado por processos biológicos anaeróbios. No entanto, vários estudos recentes têm mostrado que tal biodegradação é possível.

Almendariz et al. (2001) estudaram a degradação do LAS em reator anaeróbio de fluxo ascendente e manta de lodo (UASB) operado em dois estágios, um acidogênico e outro metanogênico. No reator acidogênico foi adicionado Pseudomonas aeruginosa que, sob condições aeróbias utiliza LAS como fonte de carbono. Os resultados indicaram, para concentração de $20 \mathrm{mg} / \mathrm{L}$ de LAS, degradação de 41\%, que ocorreu principalmente no primeiro estágio pela atividade das bactérias acidogênicas. Embora o surfactante tenha adsorvido no lodo, não inibiu os microrganismos e a produção de ácido acético. No entanto, no reator metanogênico os microrganismos foram inibidos pela presença de LAS, porém recuperados quando o surfactante foi retirado da alimentação.

Sanz et al. (2003) também estudaram a biodegradação anaeróbia do LAS em reator UASB com inóculo proveniente de reator UASB de indústria de açúcar. Foram utilizadas as seguintes condições de alimentação: (1) substratos facilmente degradáveis (acetato, propionato, butirato, lactato, metanol, etanol e sacarose) e solução comercial de LAS, durante período de três meses, (2) solução comercial de LAS, porém sem co-substratos. Ambos os reatores foram operados com taxa de carregamento orgânico entre 4 e 5 mg LAS/L.dia e tempo de detenção hidráulica de 24 horas. O LAS foi analisado no afluente e efluente do reator, assim como a quantidade adsorvida no lodo. Os resultados indicaram remoção relacionada à biodegradação primária de 64\%, para o primeiro caso, e 85\% na segunda condição de alimentação. Nota-se que a biodegradação foi mais elevada na ausência de cosubstratos do que na presença de fontes adicionais de carbono. Essa possibilidade indicou que o LAS pode ser utilizado como fonte de carbono e energia pelas bactérias anaeróbias.

Os resultados obtidos por Almendariz et al. (2001) e Sanz et al. (2003) indicaram que a degradação anaeróbia do LAS requer consórcio de bactérias. Por meio deste conhecimento, Mogensen e colaboradores (2003) utilizaram reator CSTR (continuous stirred tank reactor) em escala de laboratório, semi-contínuo, para estudar a degradação anaeróbia deste 
surfactante. Os autores testaram também reator UASB em condições termofílicas alimentado com LAS como única fonte de carbono.

No primeiro caso o reator foi inoculado com lodo estabilizado anaerobiamente de um reator CSTR, em escala de laboratório, usado na digestão de suspensão de lodo secundário de estação de tratamento de esgoto. $\mathrm{O}$ afluente foi o mesmo lodo diluído em meio mineral. $\mathrm{O}$ reator foi mantido a $37^{\circ} \mathrm{C}$, com tempo de detenção hidráulica (TDH) de 15 dias. A concentração de LAS afluente foi de 100 mg/L. Após 130 dias de operação a concentração de LAS na fase aquosa atingiu concentrações menores que $4 \mathrm{mg} / \mathrm{L}$. Para aumentar a biodisponibilidade do LAS, a quantidade de sólidos totais foi diminuída diluindo-se o lodo afluente. Já no segundo caso, o reator UASB foi inoculado com lodo granulado de reator UASB utilizado no tratamento de efluente de polpa de papel, mantidos a $55^{\circ} \mathrm{C}$ e $\mathrm{TDH}$ de 12 horas. O afluente consistia de meio mineral com $10 \mathrm{mg} / \mathrm{L}$ de LAS e solução de carbonato de sódio. Nestas condições, com LAS como única fonte de carbono e energia, 37\% de remoção foi atingida e benzaldeído foi identificado no efluente por espectômetro de massa. Comparando-se os dois sistemas, os autores concluíram que a biodisponibilidade do LAS no reator UASB foi maximizada devido à falta de sólidos suspensos na alimentação.

Reatores UASB em condições mesofílicas $\left(37^{\circ} \mathrm{C}\right)$ e termofílicas $\left(55^{\circ} \mathrm{C}\right)$ foram utilizados por Lobner et al. (2005) para avaliar a remoção de LAS em concentração afluente de $10 \mathrm{mg} / \mathrm{L}$. Os reatores foram operados por 267 dias, possuíam $200 \mathrm{ml}$ de volume e TDH de 2 dias. A estabilidade do processo quanto à variação de temperatura foi testada e notou-se ser um fator importante na remoção de LAS. Durante o estresse (diminuição da temperatura de $55^{\circ} \mathrm{C}$ para $32^{\circ} \mathrm{C}$ ) ocorreu inibição da metanogênese acetoclástica na presença de LAS. Na presença do surfactante, os microrganismos migraram para o centro dos grânulos devido a maior concentração de LAS em relação a solução, tornando os grânulos maiores. Neste trabalho, o reator termofílico apresentou resultados melhores que o mesofílico removendo $80 \%$ no primeiro caso e $40 \%$ no segundo.

Khleifat (2006) investigou a biodegradação do LAS por consórcio de bactérias facultativas. Pantoea agglomerans e Serratia odorífera 2 foram isoladas do lodo de estação de tratamento de esgoto. As bactérias foram submetidas a duas condições distintas de crescimento: (1) em meio mínimo M9 e (2) em caldo nutriente. As culturas foram submetidas ao crescimento, separadamente e em consórcio, nas duas condições nutricionais e na presença de LAS. Os reatores com células suspensas foram mantidos em temperatura de $32{ }^{\circ} \mathrm{C}$ e agitação de $250 \mathrm{rpm}$. O autor constatou que existiu cooperação catabólica, sendo que as bactérias foram mais hábeis em degradar o LAS em consórcio microbiano. Para 200 mg/L de 
LAS como única fonte de carbono, degradação de $70 \%$ foi alcançada em caldo nutriente e $36 \%$ em meio mínimo M9. No entanto, outras condições foram estudadas, tais como, variação do co-substrato (glicose, sacarose, maltose, manitol e ácido succínico) e variação da fonte de nitrogênio (cloreto de amônio, triptona, extrato de levedura, nitrato de amônio e caseína). Em todos os casos, a degradação de LAS aumentou na presença do co-substrato de carbono e fonte de nitrogênio atingindo sua completa mineralização em 48-72 horas.

A utilização de reator anaeróbio horizontal de leito fixo (RAHLF) tem sido estudada para degradação de LAS. Duarte (2006) utilizou dois reatores, inoculados com lodos de diferentes origens, preenchidos com espuma de poliuretano como material suporte. Um dos reatores foi inoculado com lodo de estação de tratamento de esgoto (ETE) e o outro com lodo proveniente de reator UASB utilizado no tratamento de dejetos de suinocultura. Os reatores foram alimentados com substrato sintético e LAS em duas concentrações, com tempo de detenção hidráulica de 12 horas. Na primeira etapa foram adicionados $7 \mathrm{mg} / \mathrm{L}$ de LAS ao substrato e na segunda, $14 \mathrm{mg} / \mathrm{L}$ de LAS nos dois reatores. Terceira etapa foi realizada no reator inoculado com lodo de suinocultura na qual as fontes orgânicas foram retiradas da composição do substrato sintético restando na alimentação apenas o LAS como fonte de carbono para os microrganismos.

Os resultados indicaram que a presença de LAS na alimentação não influenciou na remoção de matéria orgânica (em torno de $80 \%$ para ambos os reatores) e que os inóculos, apesar de possuírem origens distintas, foram capazes de degradar o LAS (DUARTE, 2006).

Através do balanço de massa obteve-se que os reatores inoculados com lodo de ETE e de suinocultura degradaram 35\% e 34\% do LAS adicionado, respectivamente, após 313 dias de operação. Na ausência de outras fontes de carbono como sacarose, extrato de levedura e amido, a eficiência de remoção do surfactante foi consideravelmente maior, atingindo $91 \%$, neste período de operação (DUARTE, 2006).

Por meio das técnicas de PCR/DGGE e recortes de bandas do gel foram identificados microrganismos do grupo BRS, os quais estiveram presentes nos reatores, mesmo na presença de baixas concentrações de sulfato. Segundo Duarte (2006), provavelmente, tais microrganismos estiveram envolvidos na degradação do surfactante utilizando a molécula como fonte de carbono e enxofre para realização das reações catabólicas e anabólicas.

Degradação de LAS foi também estudada em dois reatores anaeróbios horizontais de leito fixo (RAHLF) (OLIVEIRA, 2006). Ambos os reatores foram inoculados com lodo proveniente de reator UASB utilizado no tratamento de dejetos de suinocultura, porém os materiais suporte foram distintos. Um dos reatores foi preenchido com carvão vegetal e o 
outro possuía leito misto de argila expandida e espuma de poliuretano. A alimentação consistia de substrato sintético acrescido de $14 \mathrm{mg} / \mathrm{L}$ de LAS. Após 343 dias de operação, o reator preenchido com carvão vegetal apresentou degradação biológica de $28 \%$ de todo o LAS adicionado, enquanto, no reator de leito misto foi de $27 \%$.

A Tabela 3.2 sumariza os pontos dos principais tabalhos citados anteriormente.

Mungray e colaboradores (2008) estudaram a secagem e estabilização de lodo granulado de reator UASB em leito convencional de secagem de areia. Tal processo incluiu espessamento, desidratação, armazenamento, estabilização, evaporação, biodegradação aeróbia e anaeróbia, tratamento térmico, moagem, e aeração. Depois da aplicação do lodo neste leito de secagem, parte da quantidade de água infiltrou, e foi coletada por um sistema de drenagem e recirculação, de volta ao topo da câmara de areia. O restante da umidade evaporou lentamente. Neste estudo, a secagem em leito de areia reduziu a concentração de surfactante aniônico, em cerca de 80\% (7347 - 1452 mg/kg massa seca). Assim, a aplicação do lodo anaeróbio úmido de reator UASB em leitos de secagem não só resultou na redução do volume na secagem, mas também em considerável eliminação do surfactante variando de $66 \%$ a $85 \%$.

A cinética de secagem foi de $1^{\mathrm{a}}$ ordem. Valores de $k_{\mathrm{SA}}$ (velocidade de degradação do surfactante) foram encontrados como $0,034 \mathrm{~d}^{-1}$ e meia vida de 20 dias. Painter e Zabel (1989) encontraram que a digestão anaeróbia de lodo de esgoto começa a ser inibida em concentração maior que $15.000 \mathrm{mg}$ LAS/kg massa seca em lodo bruto.

Garcia e colaboradores (2009) estudaram a biodegradabilidade e toxicidade dos surfactantes sulfonados em ambiente aquático aeróbio e anaeróbio. Para isso, cinco surfactantes aniônicos sulfonados foram testados em concentração variando de 20 a $200 \mathrm{mg} \mathrm{C} / \mathrm{L}$ (que corresponde a, aproximadamente, 15 a $150 \mathrm{~g}$ surfactante/kg lodo seco). No teste aeróbio, foi avaliada a concentração de $\mathrm{CO}_{2}$ no headspace indicativa da biodegradação final. Nos testes anaeróbios, realizados em batelada, a produção do biogás (metano e dióxido de carbono) foi usada para avaliar a biodegradação final, e comparado com um controle, sem a adição da substância testada. $O$ tempo de incubação foi de cerca de 70 dias. 
Tabela 3.2: Quadro resumo dos trabalhos sobre degradação anaeróbia de LAS

\begin{tabular}{|c|c|c|c|c|c|c|c|c|}
\hline Reator & Inóculo & Alimentação & TDH & Material suporte & Temperatura & $\begin{array}{c}\text { LAS } \\
\text { inicial } \\
\end{array}$ & \% remoção & Referência \\
\hline $\begin{array}{l}\text { UASB - } 2 \\
\text { estágios }\end{array}$ & & $\begin{array}{c}\text { LAS mais lactose e } \\
\text { nitrato }\end{array}$ & $24 \mathrm{~h}$ & - & $35^{\circ} \mathrm{C}$ & $20 \mathrm{mg} / \mathrm{L}$ & $41 \%$ & $\begin{array}{l}\text { Almendariz et } \\
\text { al., } 2001\end{array}$ \\
\hline UASB & UASB de indústria de açúcar & Co-substratos & $24 \mathrm{~h}$ & - & $30^{\circ} \mathrm{C}$ & $\begin{array}{c}4-5 \\
\text { mg/L.dia }\end{array}$ & $64 \%$ & $\begin{array}{c}\text { Sanz et al., } \\
2003\end{array}$ \\
\hline UASB & UASB de indústria de açúcar & Somente LAS & $24 \mathrm{~h}$ & - & $30^{\circ} \mathrm{C}$ & $\begin{array}{c}4-5 \\
\text { mg/L.dia }\end{array}$ & $85 \%$ & $\begin{array}{l}\text { Sanz et al., } \\
2003\end{array}$ \\
\hline CSTR & $\begin{array}{c}\text { Lodo anaeróbio de CSTR } \\
\text { tratando lodo secundário de } \\
\text { ETE }\end{array}$ & $\begin{array}{l}\text { Alfuente de ETE } \\
\text { mais meio mineral }\end{array}$ & $\begin{array}{c}15 \\
\text { dias }\end{array}$ & - & $37^{\circ} \mathrm{C}$ & $100 \mathrm{mg} / \mathrm{L}$ & $\begin{array}{l}<4 \mathrm{mg} / \mathrm{L} \mathrm{no} \\
\text { efluente }\end{array}$ & $\begin{array}{l}\text { Mogensen et } \\
\text { al., } 2003\end{array}$ \\
\hline UASB & $\begin{array}{l}\text { UASB de efluente de indpustria } \\
\text { de papel }\end{array}$ & $\begin{array}{l}\text { LAS mais meio } \\
\text { mineral }\end{array}$ & $12 \mathrm{~h}$ & - & $55^{\circ} \mathrm{C}$ & $10 \mathrm{mg} / \mathrm{L}$ & $37 \%$ & $\begin{array}{l}\text { Mogensen et } \\
\text { al., } 2003\end{array}$ \\
\hline UASB & $\begin{array}{l}\text { Mistura de lodo granular de de } \\
\text { fábrica de lactato e lodo } \\
\text { digerido de ETE }\end{array}$ & & 2 dias & - & $37^{\circ} \mathrm{C}$ & $10 \mathrm{mg} / \mathrm{L}$ & $80 \%$ & $\begin{array}{l}\text { Lobner et al., } \\
\qquad 2005\end{array}$ \\
\hline UASB & $\begin{array}{c}\text { Mistura de lodo granular de } \\
\text { fábrica de lactato e lodo } \\
\text { digerido de ETE }\end{array}$ & & 2 dias & - & $55^{\circ} \mathrm{C}$ & $10 \mathrm{mg} / \mathrm{L}$ & $40 \%$ & $\begin{array}{l}\text { Lobner et al., } \\
2005\end{array}$ \\
\hline Batelada & $\begin{array}{c}\text { Consórcio de bactérias } \\
\text { facultativas }\end{array}$ & $\begin{array}{l}\text { Las mais Meio } \\
\text { mínimo M9 }\end{array}$ & & - & $32^{\circ} \mathrm{C}$ & $200 \mathrm{mg} / \mathrm{L}$ & $36 \%$ & Khleifat 2006 \\
\hline Batelada & $\begin{array}{c}\text { Consórcio de bactérias } \\
\text { facultativas }\end{array}$ & $\begin{array}{l}\text { LAS mais Caldo } \\
\text { nutriente }\end{array}$ & & - & $32^{\circ} \mathrm{C}$ & $200 \mathrm{mg} / \mathrm{L}$ & $70 \%$ & Khleifat 2006 \\
\hline RAHLF & Lodo de ETE & $\begin{array}{l}\text { LAS mais substrato } \\
\text { sintético }\end{array}$ & $12 \mathrm{~h}$ & $\begin{array}{l}\text { Espuma de } \\
\text { poliuretano }\end{array}$ & $30^{\circ} \mathrm{C}$ & $14 \mathrm{mg} / \mathrm{L}$ & $35 \%$ & Duarte 2006 \\
\hline RAHLF & $\begin{array}{l}\text { UASB tratando dejetos de } \\
\text { suinocultura }\end{array}$ & $\begin{array}{l}\text { LAS mais substrato } \\
\text { sintético }\end{array}$ & $12 \mathrm{~h}$ & $\begin{array}{l}\text { Espuma de } \\
\text { poliuretano }\end{array}$ & $30^{\circ} \mathrm{C}$ & $14 \mathrm{mg} / \mathrm{L}$ & $34 \%$ & Duarte 2006 \\
\hline RAHLF & $\begin{array}{l}\text { UASB tratando dejetos de } \\
\text { suinocultura }\end{array}$ & Somente LAS & $12 \mathrm{~h}$ & $\begin{array}{l}\text { Espuma de } \\
\text { poliuretano }\end{array}$ & $30^{\circ} \mathrm{C}$ & $14 \mathrm{mg} / \mathrm{L}$ & $91 \%$ & Duarte 2006 \\
\hline RAHLF & $\begin{array}{l}\text { UASB tratando dejetos de } \\
\text { suinocultura }\end{array}$ & $\begin{array}{l}\text { LAS mais substrato } \\
\text { sintético }\end{array}$ & $12 \mathrm{~h}$ & Carvão vegetal & $30^{\circ} \mathrm{C}$ & $14 \mathrm{mg} / \mathrm{L}$ & $28 \%$ & Oliveira 2006 \\
\hline RAHLF & $\begin{array}{l}\text { UASB tratando dejetos de } \\
\text { suinocultura }\end{array}$ & $\begin{array}{l}\text { LAS mais substrato } \\
\text { sintético }\end{array}$ & $12 \mathrm{~h}$ & $\begin{array}{l}\text { Argila expandida e } \\
\text { Espuma de } \\
\text { poiuretano }\end{array}$ & $30^{\circ} \mathrm{C}$ & $14 \mathrm{mg} / \mathrm{L}$ & $27 \%$ & Oliveira 2006 \\
\hline
\end{tabular}


O nível de mineralização aeróbia foi de apenas $61 \%$ para um dos surfactantes (MES metil ester sulfonado), $80 \%$ para três deles (AOS - alfaoleofino sulfonado, SAS - alcano secundário sulfonado e di- $\mathrm{C}_{8}-\mathrm{SS}$ - dialquil sulfosuccinato) e mais de $90 \%$ para $\mathrm{C}_{12}(\mathrm{EO})_{3}-\mathrm{SS}-$ monoalquil etoxi sulfosuccinato. Apesar de alguns alcançarem a mesma porcentagem de biodegradação; a velocidade de degradação foi diferente entre eles. Diferenças significativas na biodegradação final sob condições aeróbias entre cadeias lineares e ramificadas vêm sendo amplamente reportadas para alquilbenzenos sulfonados (SCHÖBERL, 1989; SCOTT e JONES, 2000).

No caso da degradação anaeróbia, a biodegradação primária foi calculada pelo balanço de massa total dos surfactantes aniônicos nos digestores. Diferentes porcentagens de remoção foram obtidas: $10,12,40$ e 70\% para AOS, SAS, MES e di-C ${ }_{8}-\mathrm{SS}$ e $\mathrm{C}_{12}(\mathrm{EO})_{3}-\mathrm{SS}$, respectivamente. Tais diferenças podem ser atribuídas a sua estrutura molecular. Para avaliação da biodegradação final foi medida a produção de biogás nos digestores. Para os três surfactantes mais persistentes (SAS, AOS e MES) a produção do biogás foi menor do que no digestor controle (produção endógena). Portanto, esses surfactantes não foram mineralizados nos digestores anaeróbios. A inibição da atividade anaeróbia aumentou com a concentração do surfactante. Para a menor concentração testada (15 g/kg lodo seco), a inibição do biogás produzido por SAS e AOS foi menor que 10\%, enquanto, MES apresentou inibição de produção de biogás maior que $20 \%$. No entanto, é importante destacar que, até mesmo o LAS, que é usado em quantidades muito mais elevadas, não é comumente encontrado em concentrações mais altas que $15 \mathrm{~g} / \mathrm{kg}$ lodo seco. Para a mais alta concentração estudada $(140 \mathrm{~g} / \mathrm{kg}$ lodo seco) a inibição da atividade anaeróbia aumentou mais dramaticamente para SAS e AOS (90\%) que para MES (70\%) (GARCIA et al., 2009).

\subsection{Material Suporte para Imobilização da Biomassa}

Reatores com células imobilizadas são alternativas potenciais na área de tratamento de efluentes e, consequentemente, os suportes para crescimento da biomassa podem ser uma importante ferramenta para aumentar o equilíbrio microbiano necessário em reatores empregados em tratamento de águas residuárias.

Uma das maneiras de obter-se elevados níveis de biomassa no reator é por meio da utilização de material suporte (HUYSMAN et al., 1983; MULCAHY e SHIEH, 1987). No 
entanto, a escolha do material suporte pode ser um fator determinante na seleção da população microbiana e diferentes suportes podem ser usados para aplicações específicas.

Ampla variedade desses materiais tem sido usada tanto em escala de laboratório quanto industrial em reatores anaeróbios de filme fixo, por exemplo. Entre as vantagens do crescimento aderido encontra-se a obtenção de elevados tempos de retenção de sólidos para relativamente baixos tempos de detenção hidráulica (PARKIN e SPEECE, 1983).

O tipo de suporte usado para imobilização de biomassa anaeróbia pode afetar a eficiência do biorreator, uma vez que o número e tipo de células aderidas ao suporte podem variar de um suporte para outro. Adesão celular pode ser afetada por várias propriedades físico-químicas do material e pela hidrodinâmica do reator, que é importante durante o estabelecimento da camada microbiana. Diferentes materiais suporte podem levar a diferentes equilíbrios microbianos que afetam diretamente o desempenho e estabilidade do reator. Além disso, a quantidade de biomassa retida no reator é fortemente dependente do suporte. A falha ou sucesso de um reator anaeróbio em uma aplicação específica pode estar diretamente ligado com o material usado para formação do biofilme (SILVA et al., 2006).

Os fatores que afetam a velocidade de colonização dos suportes são a rugosidade da superfície, porosidade total, além do tamanho dos poros e área superficial específica. Filtros anaeróbios contendo suportes com elevada porosidade apresentam melhores eficiências que reatores preenchidos com suportes não porosos. A eficiência na remoção de matéria orgânica em reatores de leito fixo está diretamente relacionada com as características do material suporte usado para a imobilização dos microrganismos anaeróbios (YANG et al., 2004).

Urrutia et al. (1999) testaram esferas de argila (5 mm de diâmetro) e bioblocos de polietileno ( $4 \mathrm{~mm}$ de diâmetro por $8 \mathrm{~mm}$ de comprimento) para degradar substrato simulando efluente da indústria de pesca. Os autores verificaram o efeito desse efluente no biofilme de arquéias metanogênicas desenvolvido sobre o material suporte em reatores com biomassa imobilizada. Uma vez que a adição de materiais suporte para reter biomassa bacteriana em reatores anaeróbios aumenta a imobilização preferencial de arquéias metanogênicas e, conseqüente, aumento da produção de metano, os autores concluíram que o aumento das arquéias metanogênicas nos reatores com argila foi atribuído a significante contribuição para imobilizar número maior de arquéias acetoclásticas semelhantes a Methanosaeta. De fato, a adesão bacteriana é afetada pelas características físicas e químicas do material suporte.

Uma vez que a degradação biológica pode ocorrer após a adsorção física na matriz, escolher um bom suporte é muito importante no processo de imobilização celular. Carvão ativado granular (CAG) tem se tornado um material atrativo para imobilização de biomassa 
porque proporciona área superficial mais uniforme e boa resistência ao esmagamento, permitindo melhor controle operacional (MA et al., 2006).

Ao longo dos últimos 25 anos, carvão ativado em pó (CAP) tem sido amplamente utilizado em conjunto com microrganismos na remoção de matéria orgânica de águas residuárias (NG et al., 1987; KOLB e WILDERER, 1997; WALKER e WEATHERLEY, 1999; SIROTKIN et al., 2001). Além disso, esse material suporte é também aplicado para tratamento de águas residuárias contaminadas com fenol, ácidos voláteis, compostos orgânicos aromáticos e alifáticos (ORSHANSKY e NARKIS, 1997; HA e VINITNANTHARAT, 2000; PANNU et al., 2003).

A média de tamanho do CAP está em torno de 15 a $25 \mu \mathrm{m}$. Carvão ativado granular (CAG) pode ser encontrado tanto na forma de grânulos esmagados quanto de pellet. Durante qualquer tipo de tratamento, os sítios disponíveis para adsorção no carvão ativado diminuem com os poluentes adsorvidos resultando em menor capacidade adsortiva do carvão. Portanto, o carvão deve ser substituído ou regenerado.

Além do carvão ativado proporcionar boa capacidade de adsorção bacteriana, ainda, existe a vantagem de regeneração biológica após sua utilização.

Bioregeneração é definida como a renovação da capacidade adsortiva do carvão ativado por microrganismos para posterior adsorção. É dependente de vários fatores incluindo biodegradabilidade, adsorbilidade e dessorbilidade do substrato, características do carvão ativado e configuração do processo. Além disso, a bioregeneração pode ser otimizada variando-se as condições operacionais.

A regeneração do carvão ativado granular é mais fácil que a do carvão ativado em pó. Contudo, ambos os processos requerem grandes investimentos e custos operacionais. A biodegradação dos compostos orgânicos adsorvidos representa um processo alternativo para regenerar carvão ativado. Este processo, chamado bioregeneração, se ocorrer durante o tratamento pode diminuir os custos de regeneração e substituição do carvão ativado, porque aumenta o tempo de vida tanto do CAP quanto do CAG.

Adsorção por carvão ativado e degradação biológica são dois métodos importantes usados no tratamento de águas residuárias industriais. Com a ajuda desses métodos é possível eliminar praticamente todos os contaminantes da água residuária. Geralmente, as substâncias que são facilmente adsorvidas são também dificilmente biodegradadas (SIROTKIN et al., 2001).

Existem duas hipóteses para o processo de bioregeneração do carvão ativado após o processo de tratamento biológico de águas residuárias: 
1 - Degradação de substâncias adsorvidas devido a exoenzimas liberadas pelos microrganismos (RODMAN, $1973{ }^{1}$ APUD SIROTKIN et al., 2001).

2 - Regeneração parcial do material suporte (ANDREWS e TIEN, 1981²APUD SIROTKIN et al., 2001).

A primeira hipótese considera que, como o tamanho das células bacterianas é muito grande para infiltração nos poros do carvão, a biodegradação nos poros é substituída por enzimas extracelulares que são capazes de entrar nos microporos e podem então reagir com o substrato adsorvido e promover sua lise hidrolítica. Devido a menor afinidade adsortiva dos produtos da lise, eles são dessorvidos e se tornam acessíveis para a biodegradação pelas células microbianas.

De acordo com a segunda hipótese, pelo menos regeneração parcial do carvão ativado ocorreria por causa do desenvolvimento do processo biológico na sua superfície em combinação com os processos de adsorção, dessorção e difusão nos poros. As substâncias adsorvidas no carvão (substrato para os microrganismos) são dessorvidas para o biofilme externo e fase líquida, e se tornam acessíveis a degradação microbiana.

\subsection{Reatores Anaeróbios com Biomassa Imobilizada}

Tratamento anaeróbio tem se tornado uma opção viável tanto técnica como economicamente para tratamento de efluentes líquidos após o desenvolvimento das seguintes configurações: reator anaeróbio de fluxo ascendente e manta de lodo (UASB), reator de leito expandido granular, biofiltro anaeróbio e reator anaeróbio de leito fluidificado (RALF).

O termo "biofilm reactor" refere-se à classe de biorreatores onde o biocatalisador existe em uma forma aglomerada, tanto na superfície de um material inerte, quanto aderidos uns aos outros. O suporte pode ser a parede do reator ou algum material inerte. Biocatalisadores, tais como, microrganismos podem crescer aderidos uns aos outros, dando origem ao grânulo. Tipicamente, nestes reatores, a velocidade de conversão do substrato é

\footnotetext{
${ }^{1}$ Rodman C.A. Factors involved with biological regeneration of activated carbon adsorbers. J. Water Pollut. Control Federation 55, 1168-1173, 1973.

2 Andrews G.F. and Tien C. Bacterial film growth in adsorbent surfaces. Am. Int. Chem. Environ. J. 27, 396-403, 1981.
} 
limitada pela velocidade de seu transporte do substrato através do biofilme (SARAVANAN e SREEKRISHNAN, 2006).

O Reator Anaeróbio Horizontal de Leito Fixo (RAHLF) em escala de bancada foi desenvolvido por Zaiat et al. (1994). Esse reator foi concebido para ser preenchido com biomassa imobilizada em matrizes cúbicas de poliuretano de 3 a $5 \mathrm{~mm}$ de aresta e proporcionar escoamento predominantemente pistonado.

Foresti et al. (1995) utilizaram essa configuração de reator para o tratamento de água residuária de indústria de papel reciclado. $\mathrm{O}$ inóculo utilizado foi lodo anaeróbio proveniente de reator UASB usado no tratamento de efluente da indústria de papel reciclado, imobilizado em espuma de poliuretano. $\mathrm{O}$ reator foi operado a temperatura ambiente (média de $23^{\circ} \mathrm{C}$ ) durante 26 dias, com TDH constante de 23 horas e carga orgânica de $2,0 \mathrm{kgDQO} / \mathrm{m}^{3} . \mathrm{d}$. Depois de 8 dias de operação, a concentração de ácidos voláteis efluente foi próxima de zero. A remoção de DQO foi de $86 \%$ no décimo dia de operação, demonstrando rápida adaptação e crescimento da biomassa.

Posteriormente, diversos trabalhos foram desenvolvidos no tratamento de águas residuárias e compostos tóxicos utilizando RAHLF e biomassa imobilizada em espuma de poliuretano (DAMIANOVIC, 1997; TELH, 2001; DE NARDI, 2002; DUARTE, 2006; OLIVEIRA, 2006). No entanto, problemas com entupimento do leito do reator foram comuns quando se utilizou tal suporte devido à formação de polímeros extracelulares em excesso elevando a perda de carga no interior do reator e, conseqüentemente, dificultando o fluxo da alimentação. Na tentativa de minimizar esse problema, a espuma de poliuretano, ou parte dela, pode ser substituída por argila expandida (cinasita) como suporte de imobilização da biomassa.

Mensah e Forster (2003) estudaram a degradação de surfactante em filtro anaeróbio, com tempo de detenção hidráulica de 18 horas e carvão ativado como suporte de imobilização da biomassa. Os autores utilizaram mistura constituída por surfactante aniônico, catiônico, não-iônico e anfótero. A vantagem de usar carvão ativado foi relacionada com a adsorção e, conseqüente controle da inibição. Além disso, o LAS adsorvido pode também ser degradado regenerando os sítios ativos do carvão. Os autores verificaram que a capacidade de adsorção no carvão ativado foi excedida (conforme ensaios de adsorção realizados previamente) depois de se adicionar a mistura de surfactantes na concentração de $4 \mathrm{~mL} / \mathrm{L}$. A remoção do surfactante continuou a ocorrer mesmo depois desse ponto. Isso mostrou que ambas, sorção e degradação, estavam ocorrendo simultaneamente. O experimento durou cerca de 90 dias e, após 65 dias, do início da operação o carvão estava totalmente saturado. 
Leite (2005) utilizou reator anaeróbio horizontal de leito fixo preenchido com argila expandida e alimentado com substrato sintético à base de glicose para produção de ácidos graxos voláteis (AGVs). Foram testadas alimentações com concentração de glicose de $2 \mathrm{~g} / \mathrm{L}$ e $4 \mathrm{~g} / \mathrm{L}$ e tempos de detenção hidráulica (TDH) de 2 horas e 0,5 hora. $\mathrm{O}$ autor verificou que a argila expandida permitiu boa aderência da biomassa anaeróbia, principalmente para menores tempos de detenção hidráulica. Quanto à produção de ácidos orgânicos, foi verificado que ácido acético e ácido butírico predominaram no efluente do reator, seguidos pelo ácido propiônico.

Assim, o estudo de diferentes materiais suportes para imobilização de biomassa faz-se importante no tratamento de matéria orgânica e mesmo de compostos tóxicos. No entanto, tais estudos devem sempre estar associados às características do reator, inóculo e água residuária.

\subsection{Reator de Leito Fluidificado}

Uma vez que as velocidades de crescimento de bactérias anaeróbias são muito baixas, elevado tempo de detenção em reator anaeróbio é necessário para degradação suficiente da matéria orgânica. Portanto, muitas pesquisas têm sido direcionadas para o desenvolvimento de técnicas para manter elevada concentração de biomassa em reatores anaeróbios tratando água residuária (KUBA et al., 1990).

Além dos sistemas anaeróbios citados anteriormente, o reator anaeróbio de leito fluidificado é uma configuração atual que também pode ser utilizada como tecnologia para tratamento do LAS presente em esgoto sanitário. Esse reator é comumente empregado no tratamento de águas residuárias industriais e sua aplicação tem aumentado devido às vantagens sobre os processos tradicionais.

O reator de leito fluidificado consiste de um vaso cilíndrico contendo meio suporte inorgânico que é fluidificado pela velocidade ascendente do líquido criada pelas taxas de escoamento de alimentação e recirculação. Um separador no topo do reator garante a eficiência de separação do líquido, biogás e sólido. Esse sistema possui leito móvel e filme fixo e envolve a interação entre as fases sólida, líquida e gasosa. A fase sólida é formada pelas biopartículas (material suporte + biofilme) que se destinam à retenção da biomassa no reator, enquanto a fase líquida é constituída pelo afluente a ser tratado. A fase gasosa, por sua vez, é oriunda da geração interna de biogás (FAN, 1989). 
Em reatores anaeróbios de leito fluidificado, o líquido a ser tratado é bombeado através do leito de partículas inertes (tipicamente areia com tamanho de partícula entre 0,2 e $0,8 \mathrm{~mm}$ ) a uma velocidade suficiente para causar a fluidificação (10 a $20 \mathrm{~m} / \mathrm{h}$ ). No estado fluidificado, o meio fornece grande superfície para o crescimento biológico aderido e permite altas concentrações de biomassa (COOPER e SUTTON, 1983). Comparados a outros reatores anaeróbios de alta taxa como o UASB, o sistema de leito fluidificado apresenta as seguintes vantagens: maior capacidade de purificação, não entupimento do reator (como um filtro), sem problemas de lavagem do lodo, além de necessitar de pequenas áreas para construção (HEIJNEN et al., 1989).

O leito de material suporte (areia, carvão ativado, argila, pérolas de vidro, etc.) permanece suspenso pelo resultado do movimento vertical ascendente da água residuária a ser tratada. Nesse leito a biomassa cresce em filmes de espessura reduzida. A fluidificação do meio reduz ou elimina os problemas de entupimento, além de aumentar a retenção de biomassa e o contato desta com o substrato, permitindo, como conseqüência, reduções significativas dos tempos de detenção hidráulica nos reatores (FAN, 1989).

Ao contrário de outros sistemas que empregam biofilmes, nos quais o meio suporte de crescimento é fixo por gravidade ou adesão direta à parede do reator, o sistema de leito fluidificado permite o crescimento do biofilme em suspensão apesar das forças causadas pelo fluxo ascendente da água residuária.

O reator anaeróbio de leito fluidificado pode ser considerado como de fluxo contínuo, mistura completa e homogêneo. Uma das principais vantagens desse reator refere-se à adesão dos microrganismos nas partículas sólidas. A área superficial permite alta concentração de biomassa, tempo de detenção hidráulica relativamente baixo dependendo da condição avaliada, elevada velocidade de reação e, por isso, o volume do reator pode ser menor. Nesse sistema é possível obter elevada eficiência de remoção e operação em regime contínuo ou intermitente (GARCÍA ENCINA e HIDALGO, 2005).

O desempenho de um processo de tratamento anaeróbio é definido pela capacidade de retenção de biomassa do reator, atividade específica do lodo, concentração e biodegradabilidade do substrato, além da vazão da água residuária. Além disso, fluxo apropriado possibilita boa distribuição da alimentação para os microrganismos, aumenta o contato entre biomassa e substrato e reduz as limitações de transferência de substrato. $\mathrm{O}$ biofilme encontrado em reatores de leito fluidificado atende a esses requisitos (PEREZ, et al., 1998, PEREZ et al. 2001). 
Segundo Sanz e Polanco (1990), o reator anaeróbio de leito fluidificado parece ser o mais promissor para tratamento de águas residuárias de baixa carga, como esgoto doméstico, uma vez que o processo mantém grande massa de microrganismos ativos e efetiva remoção de sólidos suspensos totais.

Perez et al. (1998) compararam dois reatores anaeróbios utilizados para tratamento de vinhaça em condições mesofílicas. Os reatores foram construídos em escala de bancada e eram filtro anaeróbio e reator de leito fluidificado. Dois tipos de material foram usados como suporte para a imobilização da biomassa no reator: anéis de Rashig e pérolas de vidro perfuradas. Tais suportes foram escolhidos para comparar a performance de materiais porosos e não porosos em duas tecnologias anaeróbias diferentes. Para todos os casos, a concentração de biomassa aumentou com o aumento da carga orgânica aplicada. Os resultados mostraram que as pérolas de vidro porosas tiveram rápido acúmulo de biomassa e não foram suscetíveis ao estresse de cisalhamento. Todavia, os anéis de Rashig foram os suportes mais adequados para o filtro por evitar os principais problemas desse tipo de sistema, tais como, obstrução do filtro quando ocorre excessivo crescimento microbiano.

No tratamento de vinhaça, o reator de leito fluidificado foi mais eficiente que o filtro anaeróbio devido, principalmente, ao fato de favorecer o transporte das células da solução para a superfície das partículas suporte e, assim, aumentar o contato entre os microrganismos e o substrato. Dessa maneira, concluiu-se que reatores de leito fixo são adequados para tratamento de águas residuárias de fácil degradação ou para casos em que são necessárias elevadas porcentagens de remoção de matéria orgânica, enquanto, reatores de leito fluidificado são apropriados para compostos xenobióticos e recalcitrantes (SEM e DEMIRER, 2003).

Águas residuárias geradas em diferentes etapas de produção na indústria têxtil têm elevado $\mathrm{pH}$, temperatura, detergentes, óleos, sólidos suspensos e dissolvidos, material tóxico e não-biodegradável, cor e alcalinidade. Métodos físicos e químicos são aplicados para o tratamento dessa água residuária alcançando elevada eficiência de remoção de cor (HAROUN e IDRIS, 2009). No entanto, nos últimos anos existe uma tendência em usar sistemas biológicos para tratamento de água residuária que contém cor, uma vez que os mais importantes poluentes presentes no efluente de indústria têxtil são principalmente compostos orgânicos recalcitrantes, tóxicos, surfactantes e compostos clorados (AOXs), entre outros (HAROUN e IDRIS, 2009). A natureza recalcitrante dos corantes, juntamente com sua toxicidade aos microrganismos, torna o tratamento aeróbio difícil. Assim, o tratamento anaeróbio é o mais indicado. 
Diversos são os materiais suporte utilizados para imobilização de biomassa em reatores de leito fluidificado. Além dos trabalhos citados anteriormente, Sem e Demirer (2003) utilizaram pedra-pomes no tratamento de água residuária de indústria têxtil. Neste estudo, reator de leito fluidificado de 4 litros foi utilizado com temperatura controlada de $35 \pm 2^{\circ} \mathrm{C}$. A pedra-pomes usada como suporte possuía diâmetro entre 0,25 e $1,4 \mathrm{~mm}$ e densidade de $1764 \mathrm{Kg} / \mathrm{m}^{3}$. Durante o período inicial, a alimentação do reator continha metanol, glicose, extrato de levedura e meio basal. Nessa fase a taxa de carregamento orgânico foi gradualmente elevada. No período seguinte, o reator foi alimentado com água residuária de indústria têxtil. Este período de operação foi dividido em 6 etapas. Os resultados mostraram que na primeira etapa (sem adição de carbono adicional ou fontes de nutrientes), a condição ótima de operação do reator foi alcançada quando os valores de $\mathrm{pH}$ e alcalinidade foram maiores que 6,5 e $800 \mathrm{mg} / \mathrm{L}$ ( $\left(\mathrm{momo} \mathrm{CaCO}_{3}\right.$ ), respectivamente. Na segunda etapa, com o aumento do TDH de 24 para 50 horas, a velocidade de remoção de matéria orgânica diminuiu para cerca de metade do seu valor no final da primeira etapa.

Tratamento combinado de esgoto sanitário e água residuária industrial foi simulado na terceira etapa para que as necessidades nutricionais de crescimento biológico fossem supridas. Porém, este artifício não resultou em nenhum ganho em termos de remoção de cor quando comparado a etapa anterior. Na etapa quatro, fonte de carbono exógena (glicose, na concentração de $500 \mathrm{mg} / \mathrm{L}$ ) foi adicionada à água residuária industrial e o tempo de detenção hidráulica do reator foi diminuído de 50 para 24 horas. Significante aumento na remoção de cor foi notado neste estágio. Na etapa seguinte a concentração de glicose foi aumentada para $2 \mathrm{~g} / \mathrm{L}$ e as velocidades de remoção de cor e matéria orgânica aumentaram. Na última etapa, a concentração de glicose foi aumentada para mais de $5 \mathrm{~g} / \mathrm{L}$, porém nenhum aumento na remoção de DQO ou cor foi observado (SEM e DEMIRER, 2003).

Os autores (Op cit.) observaram que existe um ponto ótimo para a adição de fontes de carbono adicionais, a partir do qual, não há a necessidade de aumento, visto que a degradação do produto desejado não se altera.

Yang et al. (2004) estudaram quatro materiais suporte com porosidades similares (maior que 90\%), porém com diferentes características, para imobilização de microrganismos. Dois suportes apresentavam poros ("loofah sponge" e espuma de poliuretano) e os outros dois possuíam fibras (fibras de carbono e lã de rocha). Foram utilizados reatores de leito fluidizado inoculados com lodo de estação de tratamento de esgoto, operados de modo semicontínuo com TDH de 12 dias e alimentados com ácido acético (5 g/L) como único substrato orgânico. Os materiais suporte e as principais morfologias celulares presentes no biofilme foram 
observados através de microscópio eletrônico de varredura. Os autores verificaram que o melhor rendimento de metano (maior produção em volume) foi obtido no reator preenchido com "loofah". A estrutura porosa da espuma e da "loofah" revelou melhor desempenho que a estrutura fibrosa do carbono e da lã, sob as condições experimentais adotadas. Por meio dos exames microscópicos verificou-se que as características diferentes do material suporte podem influenciar na aderência de microrganismos distintos.

Com a finalidade de estudar o desenvolvimento do biofilme em partículas poliméricas utilizadas como meio suporte, Sader e Silva (2005) utilizaram reator anaeróbio de leito fluidificado para tratar água residuária contendo fenol. As partículas usadas foram poliestireno, PET e PVC. Os reatores foram construídos em acrílico transparente de $5 \mathrm{~mm}$ de espessura, volume de aproximadamente $770 \mathrm{ml}$ e operados com concentração de fenol variando de 100 a $400 \mathrm{mg} / \mathrm{L}$. Remoção de até $98 \%$ de fenol foi atingida no reator preenchido com PET. A esse suporte foi atribuído melhor desempenho dentre os três avaliados, devido a não deformação das partículas durante a operação.

Damiano e Silva (2005) avaliaram o desempenho de reator anaeróbio de leito fluidificado na degradação da vinhaça de cana-de-açúcar, sob condições mesofílicas. A partícula utilizada como material suporte foi poliestireno. $\mathrm{O}$ inóculo foi proveniente de reator UASB utilizado no tratamento de água residuária de abatedouro de aves. $\mathrm{O}$ reator foi construído em acrílico transparente de $5 \mathrm{~mm}$ de espessura e volume de aproximadamente $770 \mathrm{ml}$. O tempo de detenção hidráulica (TDH) empregado foi de $24 \mathrm{~h}$ considerando todo o volume do reator. Após 122 dias de operação, remoção de $70 \%$ de matéria orgânica foi atingida para concentração inicial de $2.023 \mathrm{mg} / \mathrm{L}$. Observações microscópicas em microscópio eletrônico de varredura (MEV) mostraram boa adesão microbiana nas partículas de poliestireno.

Haroun e Idris (2009) usaram reator anaeróbio de leito fluidificado com carvão ativado como material suporte para investigar a eficiência de remoção de DQO, DBO e cor de água residuária real de indústria têxtil. O reator foi continuamente alimentado sem suplementação e, posteriormente, foi suplementado com glicose $(600 \mathrm{mg} / \mathrm{L})$ para diferentes TDHs. Os resultados indicaram que a eficiência de remoção atingiu seu ponto ótimo com adição de cosubstrato na forma de glicose. Remoção de DQO, DBO e cor atingiram valores de 98\%, 95\% e $65 \%$, respectivamente. Assim, os autores concluíram que o tratamento anaeróbio comparado aos métodos físicos e químicos oferece opção viável em termos de custo.

O desenvolvimento de biofilme anaeróbio é um processo complexo que depende de vários fatores. Muitas interações ocorrem entre a superfície do meio, os microrganismos e o 
substrato, e todos eles influenciam na retenção biológica. O reator anaeróbio de leito fluidificado com biofilme imobilizado tem sido amplamente usado como sistema de tratamento biológico de águas residuárias. Tal sistema apresenta elevada eficiência e baixo tempo de detenção hidráulica (TDH), uma vez que é eficiente e estável por usar alta retenção celular (AMORIM et al., 2009).

Sabendo que um dos principais parâmetros para boas eficiências em reatores com biofilme aderido é a escolha do suporte, Amorim e colaboradores (2009) utilizaram argila expandida em reator anaeróbio de leito fluidificado para produção do gás hidrogênio a partir da fermentação da glicose presente em água residuária sintética. Tais partículas possuíam diâmetro entre 2,8 e 3,35 mm. O inóculo foi obtido de reator UASB usado no tratamento de dejetos de suinocultura. Com a diminuição do tempo de detenção hidráulica de 8 para 2 horas, o rendimento da produção de hidrogênio aumentou de $1,41 \mathrm{~mol} \mathrm{H}_{2} / \mathrm{mol}$ glicose para 2,49 $\mathrm{mol} \mathrm{H}_{2} / \mathrm{mol}$ glicose. O consumo da glicose manteve-se próximo a $90 \%$, indicando ótima eficiência no consumo do substrato. Microscopia eletrônica de varredura das biopartículas mostrou que células, principalmente semelhantes a bacilos e endósporos, cobriam a superfície e cavidades da argila expandida, comprovando elevada retenção de biomassa no reator.

A degradação do LAS em reatores anaeróbios de leito fluidificado ainda não foi estudada. Com base nos trabalhos realizados neste tipo de reator, pode-se observar que diversos são os compostos tóxicos degradados bem como os suportes possíveis para imobilização de biomassa nessa configuração de reator.

\subsection{Considerações Finais}

Por meio dos trabalhos apresentados anteriormente sobre a molécula do LAS, sua extensa produção e consumo mundial, seus efeitos biológicos, processos de remoção e degradação, nota-se que especial atenção deve ser dada a seu destino.

Diversas são as pesquisas que se preocupam em desenvolver possibilidades tecnológicas para degradar os surfactantes presentes no esgoto sanitário e água residuária industrial, seja por processos químicos, ou biológicos envolvendo microrganismos aeróbios ou anaeróbios. Porém, ainda devem ser realizadas pesquisas para entender melhor e aperfeiçoar os diversos fatores que interferem em sua degradação, tais como, o processo empregado (configuração de reator, por exemplo), presença de determinados microrganismos 
(caractarização microbiana), produtos intermediários de sua degradação, e inibição que pode causar aos microrganismos, entre outros.

Nesse sentido, com este trabalho pretendeu-se empregar tecnologia inédita para remoção anaeróbia de LAS (reator de leito fluidificado) e avaliar a diversidade microbiana presente nos diversos materiais suporte utilizados nos reatores 


\section{MATERIAL E MÉTODOS}

Este trabalho foi realizado com a finalidade de avaliar a remoção de LAS em reator anaeróbio de leito fluidificado alimentado com substrato sintético. A Figura 4.1 destaca o fluxograma experimental empregado.

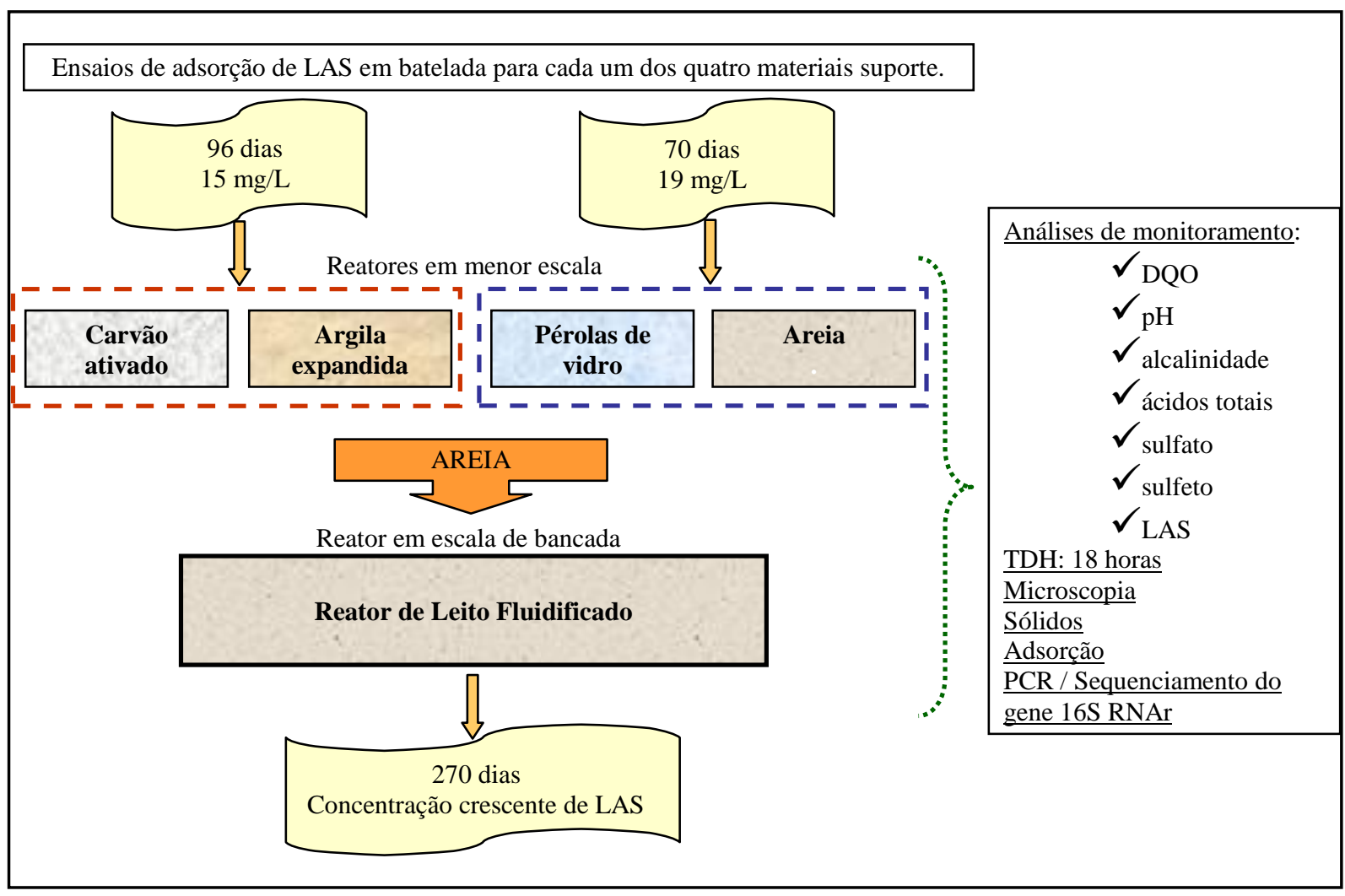

Figura 4.1: Fluxograma Experimental

Os reatores foram instalados no Laboratório de Processos Biológicos (LPB), mantidos a $30^{\circ} \mathrm{C}$ em câmara climatizada e operados com tempo de detenção hidráulica (TDH) de 18 horas. Este tempo foi escolhido entre os valores já empregados para degradação anaeróbia de LAS em reator anaeróbio horizontal de leito fixo (RAHLF) (12 horas) (DUARTE et al., 2008; DUARTE et al., 2010; OLIVEIRA et al., 2009) e aquele normalmente empregado em reatores de leito fluidificado (24 horas) (DAMIANO E SILVA, 2005; SADER E SILVA, 2005).

$\mathrm{Na}$ primeira etapa, foram utilizados reatores de leito fluidificado em menor escala (3,0 cm de diâmetro e $50 \mathrm{~cm}$ de altura) para teste do material suporte. Foram testados como suportes de imobilização da biomassa os seguintes materiais: carvão ativado, argila 
expandida, pérolas de vidro e areia. Na segunda etapa, areia foi escolhida para preencher o reator em escala de bancada $(4,0 \mathrm{~cm}$ de diâmetro e $100 \mathrm{~cm}$ de altura) utilizado na degradação do LAS. Durante a operação de todos os reatores, análises de DQO, pH, alcalinidade, ácidos totais, sulfato, sulfeto e concentração de LAS foram realizadas periodicamente. Ao final da primeira etapa, amostra de biomassa foi retirada dos reatores preenchidos com pérolas de vidro e areia para realização de análises de Biologia Molecular. As mesmas análises foram realizadas com amostra final do reator operado na segunda etapa, em escala de bancada.

Ensaio de adsorção de LAS nos materiais suporte foi realizado, em batelada, na ausência de biomassa.

A Figura 4.2 apresenta o fluxograma experimental do reator de leito fluidificado, em escala de bancada $(\sim 1250 \mathrm{~mL})$.

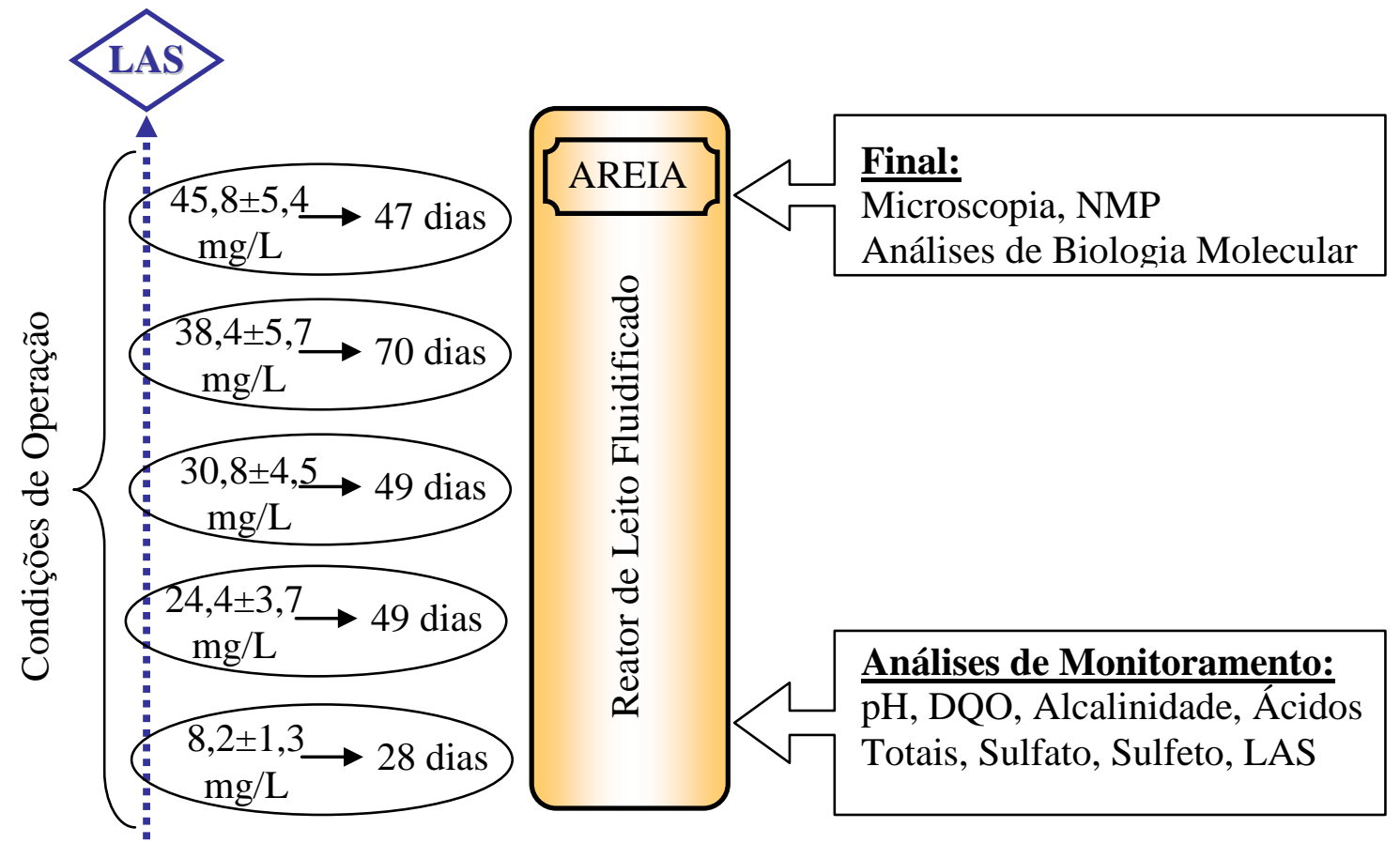

Figura 4.2: Fluxograma experimental da operação do reator.

O reator em escala de bancada utilizado durante a segunda etapa do trabalho foi operado por 270 dias, alimentado com o mesmo substrato sintético dos reatores menores, porém alimentado com concentrações crescentes de LAS. 


\subsection{Caracterização do Material Suporte}

Para imobilização da biomassa nos reatores de leito fluidificado foram utilizados quatro suportes diferentes. As características de cada suporte estão apresentadas na Tabela 4.1.

Tabela 4.1: Características do material suporte usado no reator anaeróbio de leito fluidificado em menor escala

\begin{tabular}{ccccc}
\hline Reator & Suporte & Massa $(\mathbf{g})$ & Diâmetro $(\mathbf{m m})$ & Densidade $\left(\mathbf{g} / \mathbf{c m}^{\mathbf{3}}\right)$ \\
\hline R1 & Carvão ativado & 70,0 & $1,4-1,7$ & 1,8 \\
R2 & Argila expandida & 60,0 & $2,0-2,8$ & 1,4 \\
R3 & Pérolas de vidro & 60,0 & $1,4-1,7$ & 2,2 \\
R4 & Areia & 60,0 & $1,4-1,7$ & 2,3
\end{tabular}

Área superficial específica argila expandida $=1,08 \mathrm{~m}^{2} / \mathrm{g}$; porosidade areia $=35-40 \%$

Anteriormente à sua utilização, os suportes pérolas de vidro e areia foram submetidos a tratamento ácido. A finalidade foi criar rugosidades na superfície das pérolas de vidro que facilitassem a adesão da biomassa quando da inoculação do reator. No caso da areia, pretendeu-se a remoção de impurezas. Para isso, os materiais foram mergulhados em solução de ácido fluorídrico (HF) em água destilada, $20 \%$ em volume (1:4), durante 24 horas. Foram mantidos em béquer de plástico e em intervalos regulares de tempo foram revolvidos com auxílio de bastão de PVC (Silva, 1995).

Para utilização do carvão ativado, foi necessário lavá-lo com água destilada para retirada dos finos e estabilização do pH. Após sua lavagem, o carvão foi peneirado para classificação em diversas granulometrias.

Argila expandida precisou ser fragmentada manualmente, lavada e peneirada para utilização da granulometria específica.

NaTabela 4.2 estão apresentas as características do suporte escolhido para preencher o reator em escala de bancada. 
Tabela 4.2: Características do material suporte usado reator anaeróbio de leito fluidificado em escala de bancada

\begin{tabular}{cccccc}
\hline Suporte & $\begin{array}{c}\text { Massa } \\
(\mathbf{g})\end{array}$ & $\begin{array}{c}\text { Diâmetro } \\
(\mathbf{m m})\end{array}$ & $\begin{array}{c}\text { Densidade } \\
\left(\mathbf{g} / \mathbf{c m}^{\mathbf{3}}\right)\end{array}$ & $\begin{array}{c}\text { Altura Leito } \\
\text { fixo }(\mathbf{c m})\end{array}$ & $\begin{array}{c}\text { Expansão em } \\
\text { volume }(\mathbf{\%})\end{array}$ \\
\hline Areia & 430,0 & $1,4-1,7$ & 2,3 & 33,5 & 16,4 \\
\hline
\end{tabular}

De acordo com a densidade do material, a vazão da bomba de recirculação necessária para atingir a mínima velocidade de fluidificação foi de, aproximadamente, $73 \mathrm{~L} / \mathrm{h}$. Assim, como geralmente utiliza-se a fluidificação $30 \%$ acima do valor mínimo, a vazão de recirculação deveria ser $95 \mathrm{~L} / \mathrm{h}$. No entanto, o leito de areia ficou muito revolto o que poderia dificultar a fixação da biomassa ao suporte. Assim, a vazão de recirculação foi diminuída para aproximadamente $77 \mathrm{~L} / \mathrm{h}$ por apresentar visualmente boa fluidificação.

\subsubsection{Determinação da Velocidade Mínima de Fluidificação}

Para determinação da velocidade mínima de fluidificação foi realizado experimento utilizando reator de leito fluidificado construído em acrílico com 5,0 cm de diâmetro. O reator foi preenchido com material suporte (pérolas de vidro, carvão ativado e argila expandida), separadamente, para altura de leito entre 10 e $15 \mathrm{~cm}$.

No início do experimento foi anotada a massa de suporte utilizada e a altura do leito empacotado. Posteriormente, a vazão da bomba de recirculação foi aumentada lenta e gradativamente e medidos a altura do leito expandido de material suporte, a diferença de pressão no manômetro e a vazão da água. Foram coletados dados de 10 diferentes vazões para cada um dos materiais suporte.

Com os valores de vazão e área da seção transversal do reator determinou-se a velocidade ascensional da água para cada ponto de acordo com a equação 4.3.

$$
v_{i}=\frac{Q_{i}}{A}\left[\frac{c m}{s}\right]
$$

Sendo: v: velocidade ascensional

Q: vazão de recirculação

A: área da seção transversa do reator 
O diferencial de pressão também foi calculado a partir das densidades da água, do $\mathrm{CCl}_{4}$ (tetracloreto de carbono) que foi usado para preencher o manômetro e da altura da coluna de $\mathrm{CCl}_{4}$ segundo a equação 4.4 .

$$
\Delta P_{i}=\left(\rho C C_{4}-\rho H_{2} O\right) \cdot g \cdot h_{i}\left[\frac{g}{c m \cdot s^{2}}\right] \quad \text { Equação } 4.4
$$

Sendo: $\quad \Delta \mathrm{P}:$ diferencial de pressão

$\mathrm{\rho CCl}_{4}$ : densidade do tetracloreto de carbono

$\mathrm{\rho H}_{2} \mathrm{O}$ : densidade da água

g: aceleração da gravidade

h: altura do tetracloreto de carbono na coluna

O valor da velocidade mínima de fluidificação para cada um dos materiais suporte foi obtido a partir do gráfico de variação de pressão $(\Delta \mathrm{P})$ versus velocidade ascensional $(\mathrm{v})$.

\subsubsection{Ensaio de Adsorção}

A capacidade de adsorção em relação ao LAS de cada um dos materiais suporte foi testada em ensaios realizados em batelada usando frascos Duran ${ }^{\circledR}$ de $500 \mathrm{~mL}$. Os testes foram realizados em duplicata. As massas dos diferentes suportes foram escolhidas para padronizar o volume do suporte nos diferentes frascos.

Assim, $12 \mathrm{~g}$ de carvão ativado, $10 \mathrm{~g}$ de argila expandida, $25 \mathrm{~g}$ de pérolas de vidro e $25 \mathrm{~g}$ de areia foram mantidos em contato com solução de LAS em água ultra purificada na concentração de $25 \mathrm{mg} / \mathrm{L}$ por 24 horas. Tanto os suportes quanto as soluções foram previamente esterilizados em autoclave (20 minutos, $121^{\circ} \mathrm{C}$ e $1 \mathrm{~atm}$ ) com a finalidade de impedir a interferência de microrganismos aeróbios na degradação do surfactante durante o ensaio.

Nesses ensaios foram analisadas as concentrações de LAS na solução inicial e imediatamente após entrar em contato com o suporte $(\mathrm{t}=0)$. Os frascos foram mantidos sob agitação constante de $125 \mathrm{rpm}$ a $30^{\circ} \mathrm{C}$. Amostras da solução foram coletadas após 1, 2, 3, 4, 6, 8 e 24 horas. As amostras foram filtradas em membrana $0,22 \mu \mathrm{m}$ e analisadas por HPLC para determinação da concentração de LAS. 
A Figura 4.3 apresenta o fluxograma experimental dos ensaios de adsorção em batelada.

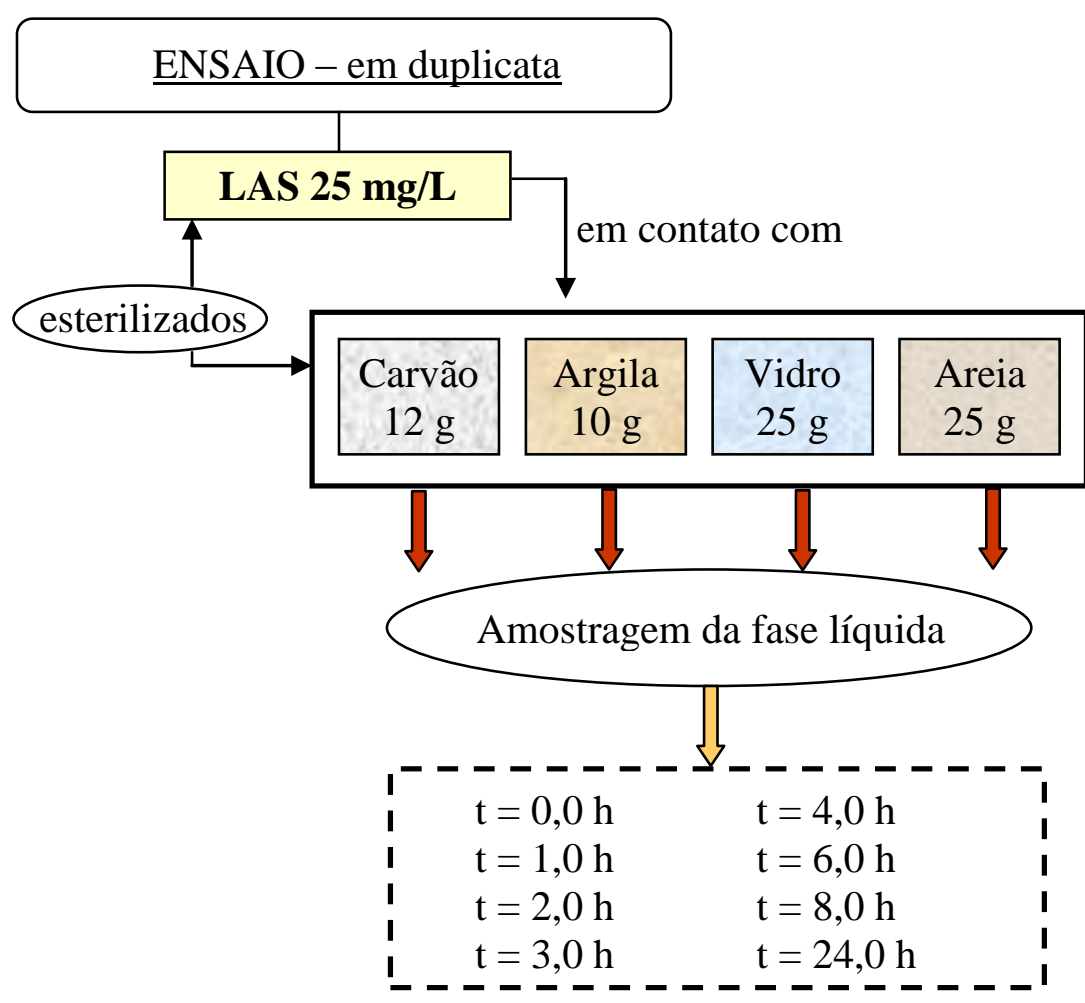

Figura 4.3: Fluxograma experimental dos ensaios de adsorção

\subsubsection{Extração do LAS Adsorvido por Ultra-som}

Amostras de material suporte mais biomassa foram retiradas dos reatores de leito fluidificado ao final da operação para determinação do LAS adsorvido e cálculo do balanço de massa de LAS no sistema.

O protocolo de extração de LAS para quantificar o surfactante adsorvido na biomassa e material suporte (DUARTE, 2006; OLIVEIRA, 2006) foi modificado a partir daquele usado pela Petroquímica espanhola (PETRESA).

Para isso, as amostras de suportes contendo LAS foram mantidas em estufa a $110^{\circ} \mathrm{C}$ por 24 horas (sempre em duplicata) para, posteriormente, ser realizado o processo de extração que consistiu nas seguintes etapas:

a- O suporte, previamente seco, foi pesado e anotada a sua massa;

b- Ao suporte, adicionaram-se $50 \mathrm{~mL}$ de metanol puro; 
c- Suporte mais metanol foram levados a banho de ultra-som durante 30 minutos a temperatura de aproximadamente $50^{\circ} \mathrm{C}$;

d- Separou-se o suporte, coletando a fase líquida;

e- As etapas (b), (c) e (d) foram repetidas mais duas vezes;

f- Ao suporte adicionaram-se $20 \mathrm{~mL}$ de água destilada;

g- As etapas (c) e (d) foram repetidas;

h- A solução formada pelo metanol coletado em cada etapa mais a água foi filtrada em membrana de $0,22 \mu \mathrm{m}$;

i- Evaporou-se o extrato metanólico em placa aquecida $\left(60^{\circ} \mathrm{C}\right)$ até o volume ser reduzido a, aproximadamente, $20 \mathrm{~mL}$;

\subsubsection{Determinação da Eficiência do Método de Extração}

Para determinação da eficiência do método de extração, cerca de $5 \mathrm{~g}$ de cada material suporte (carvão ativado, argila expandida e pérolas de vidro) foram mantidos em contato com $100 \mathrm{~mL}$ de solução contendo $25 \mathrm{mg} / \mathrm{L}$ de LAS por 24 horas em incubadora com agitação $(125 \mathrm{rpm})$ a temperatura controlada de $30^{\circ} \mathrm{C}$. Os frascos permaneceram agitados e foram preparados em duplicata.

Foram analisadas por HPLC amostras da solução inicial e do sobrenadante dos frascos após 24 horas.

Realizado o procedimento de extração, as amostras resultantes foram também analisadas para cálculo da eficiência do método de extração, em porcentagem, de acordo com a equação 4.5 .

$$
E_{\text {extração }}=\frac{\text { massa }_{\text {extraído }}}{\operatorname{massa}_{(\text {sol.inicial-sobrenadate })}} .100
$$

\subsection{Inóculo}

Todos os reatores foram inoculados com lodo proveniente de reator UASB utilizado no tratamento de dejetos de suinocultura fornecido pelo Departamento de Engenharia Rural da Universidade Estadual Paulista (UNESP), Campus de Jaboticabal - SP. Tal lodo foi escolhido devido aos bons resultados obtidos em trabalhos anteriores na degradação de 
surfactante neste laboratório de pesquisa. Não houve necessidade de desestruturar os grânulos do lodo uma vez que este se apresentava na forma floculenta, pastosa e homogênea.

O lodo utilizado neste trabalho foi submetido à determinação da quantidade de sólidos totais (ST), sólidos totais voláteis (STV) e fixos (STF) de acordo com metodologia descrita em APHA (2005).

\subsection{Composição do Substrato Sintético}

O surfactante utilizado neste trabalho foi o dodecilbenzeno sulfonado de sódio (Sigma) também conhecido como LAS comercial, com pureza de 80\%. O restante (20\%) corresponde a sulfato de sódio (15\%) e impurezas orgânicas (5\%) provenientes da fabricação (HOUSE e FARR, 1989).

Para a alimentação dos reatores em menor escala, o surfactante foi utilizado em concentração média de aproximadamente $15 \mathrm{mg} / \mathrm{L}$, enquanto que, para a alimentação do reator em escala de bancada, o surfactante foi utilizado em concentração crescente de $8,2 \pm 1,3 \mathrm{mg} / \mathrm{L}$ a 45,8 $\pm 5,4 \mathrm{mg} / \mathrm{L}$. Esgoto sintético formulado por Torres (1992) foi utilizado como base para a elaboração do substrato sintético. Algumas modificações foram necessárias, como por exemplo, a não inclusão de óleo e detergente de cozinha, uma vez que, a presença dos mesmos poderia prejudicar as análises de LAS. Além disso, o extrato de carne foi substituído pelo extrato de levedura, em virtude deste último ser rico em vitaminas do complexo B e ter sido usado com sucesso no processo de degradação anaeróbia de compostos tóxicos (MAINTINGUER, 2004).

Os reatores foram então alimentados com substrato sintético conforme apresentado na Tabela 4.3. Na Tabela 4.4 está descrita a composição da solução de sais usada no substrato sintético.

Para armazenar o substrato durante a alimentação dos reatores utilizou-se frasco Duran $^{\circledR}$ de 5,0 L que foi mantido sob refrigeração.

Tabela 4.3: Composição do substrato sintético

\begin{tabular}{lc}
\hline Nutrientes & Concentração (mg/L) \\
\hline Extrato de levedura & 500 \\
Sacarose & 80 \\
Bicarbonato de sódio & 400 \\
Solução de sais (Tabela 4.4) & $5,0 \mathrm{ml} / \mathrm{L}$ \\
\hline
\end{tabular}

Fonte: modificado de Torres (1992) 
Tabela 4.4: Composição da solução de sais do substrato sintético

\begin{tabular}{lc}
\hline Sais Inorgânicos & Concentração $(\mathbf{g} / \mathbf{L})$ \\
\hline $\mathrm{NaCl}$ & 50,0 \\
$\mathrm{MgCl}_{2} \cdot 6 \mathrm{H}_{2} \mathrm{O}$ & 1,4 \\
$\mathrm{CaCl}_{2} \cdot 2 \mathrm{H}_{2} \mathrm{O}$ & 0,9 \\
\hline
\end{tabular}

Fonte: Torres (1992)

O substrato sintético foi preparado da seguinte maneira:

(a) A solução de sais (Tabela 4.4) foi preparada previamente em água destilada e mantida em frasco âmbar de 1,0 L sob refrigeração;

(b) Os demais componentes do substrato foram pesados semanalmente e mantidos em frascos tampados sem umidade;

(c) A sacarose, extrato de levedura e bicarbonato de sódio foram dissolvidos em água da rede pública de abastecimento e agitados até a solução tornar-se transparente;

(d) A solução estoque de LAS na concentração de $4 \mathrm{~g} / \mathrm{L}$ foi mantida sob refrigeração e periodicamente renovada;

(e) Com a adaptação de bexiga de borracha no frasco de alimentação foi possível manter a anaerobiose nos frascos com atmosfera preenchida com $\mathrm{N}_{2}(100 \%)$.

\subsection{Reator de Leito Fluidificado}

A Figura 4.4 mostra o esquema de operação do reator de leito fluidificado. Os reatores foram utilizados para degradação de LAS em substrato sintético e construídos em duas escalas diferentes. O primeiro reator usado para ensaios preliminares com os materiais suporte, foi confeccionado em vidro borossilicato, possuia 3,0 cm de diâmetro e $50 \mathrm{~cm}$ de altura. Após a escolha do material suporte, o reator utilizado foi construído totalmente em acrílico com $4,0 \mathrm{~cm}$ de diâmetro e $100 \mathrm{~cm}$ de altura.

Ao longo dos reatores foram instalados pontos de amostragem para coleta de amostras, igualmente espaçados. Na base foi instalado um distribuidor para garantir a uniformidade do fluxo dentro do reator e, no topo, um separador de fases para impedir que partículas sólidas fossem levadas do reator e garantir a saída do efluente.

Nos reatores em menor escala o separador de fases e o distribuidor foram confeccionados em aço inox e conectados ao vidro de boro-silicato utilizando anéis de borracha para garantir a estanqueidade. 
A vazão de alimentação empregada nos reatores foir de $20 \mathrm{ml} / \mathrm{h}$ para os reatores em menor escala e $70 \mathrm{ml} / \mathrm{h}$ para o reator em escala de bancada.

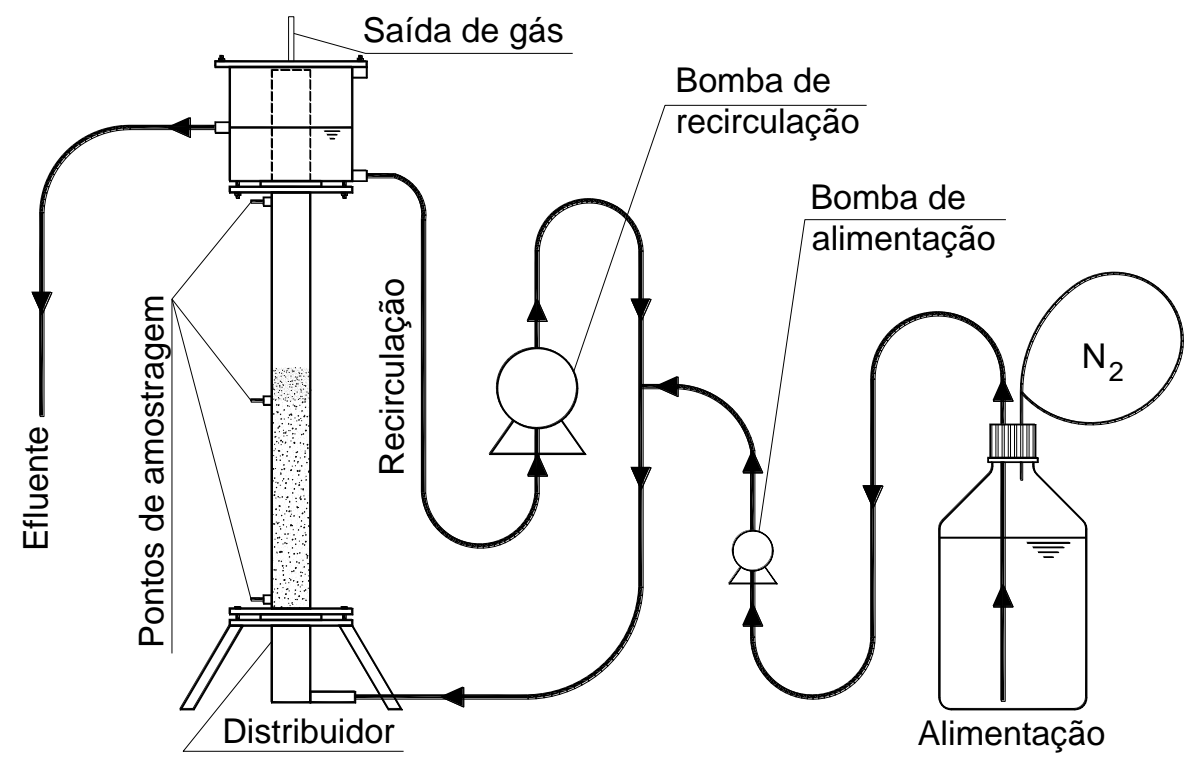

Figura 4.4: Diagrama esquemático da operação do reator de leito fluidificado

\subsubsection{Etapas de Operação}

\subsubsection{Reatores em menor escala}

Devido à indisponibilidade de espaço na câmara climatizada, foram operados dois reatores por vez. Inicialmente, estiveram em funcionamento os reatores preenchidos com carvão ativado (R1) e argila expandida (R2). Após o término da operação, a mesma câmara, bombas e reatores foram utilizados para operação com pérolas de vidro (R3) e areia (R4). A Tabela 4.5 sumariza as etapas de operação dos reatores.

A imobilização da biomassa no material suporte foi realizada mediante a adaptação da biomassa ao substrato sintético. O sistema foi mantido em circuito fechado com substrato sintético e $10 \%$ de lodo (em volume) por tempo suficiente para estabilização da matéria orgânica que foi medida diariamente e suplementada quando necessário. A temperatura foi controlada em $30^{\circ} \mathrm{C} \pm 1$. Após esse período, o sistema foi aberto e alimentado com substrato sintético. Ao longo do tempo, com o consumo da matéria orgânica pelos microrganismos anaeróbios presentes na fase líquida e no material suporte, novo substrato sintético era preparado e adicionado ao frasco contendo substrato antigo e lodo. 
Tabela 4.5: Etapas de operação

\begin{tabular}{|c|c|c|c|}
\hline Etapa & Reator & $\begin{array}{l}\text { Duração } \\
\text { (dias) }\end{array}$ & Descrição \\
\hline I & $\mathrm{R} 1$ e $\mathrm{R} 2$ & 22 & $\begin{array}{l}\text { Circuito fechado para imobilização e adaptação da } \\
\text { biomassa ao substrato sintético }\end{array}$ \\
\hline II & $\mathrm{R} 1$ e $\mathrm{R} 2$ & 49 & $\begin{array}{l}\text { Abertura dos sistemas e alimentação somente com } \\
\text { substrato sintético }\end{array}$ \\
\hline III & $\mathrm{R} 1$ e $\mathrm{R} 2$ & 47 & $\begin{array}{l}\text { Alimentação com substrato sintético acrescido de } \\
\text { LAS }\end{array}$ \\
\hline IV & $\mathrm{R} 3$ e $\mathrm{R} 4$ & 09 & $\begin{array}{l}\text { Circuito fechado para imobilização e adaptação da } \\
\text { biomassa ao substrato sintético }\end{array}$ \\
\hline V & $\mathrm{R} 3$ e $\mathrm{R} 4$ & 27 & $\begin{array}{l}\text { Abertura dos sistemas e alimentação somente com } \\
\text { substrato sintético }\end{array}$ \\
\hline VI & $\mathrm{R} 3$ e $\mathrm{R} 4$ & 43 & $\begin{array}{l}\text { Alimentação com substrato sintético acrescido de } \\
\text { LAS }\end{array}$ \\
\hline
\end{tabular}

O maior período de duração da etapa I (reatores 1 e 2 ) em relação a etapa IV (reatores 3 e 4) foi devido ao tempo necessário para aprendizagem na operação do sistema, como por exemplo, manipulação da bomba de recirculação, adaptação de bexigas com $\mathrm{N}_{2}$ para manter a atmosfera anaeróbia e controle de vazamentos. Tal experiência tornou possível a realização, em menor período, a imobilização da biomassa nos reatores R3 e R4 (etapa IV).

4.1.1.2. Reator em escala de bancada

O reator em escala de bancada preenchido com areia como material suporte foi operado nas condições apresentadas na Tabela 4.6.

Tabela 4.6: Etapas de operação do reator em escala de bancada

\begin{tabular}{|c|c|c|}
\hline Etapa & $\begin{array}{l}\text { Duração } \\
\text { (dias) }\end{array}$ & Descrição \\
\hline Início & 14 & $\begin{array}{l}\text { Circuito fechado para imobilização e adaptação da biomassa ao } \\
\text { substrato sintético }\end{array}$ \\
\hline I & 28 & Abertura do sistema e alimentação somente com substrato sintético \\
\hline II & 28 & $\begin{array}{l}\text { Alimentação do reator com substrato sintético acrescido de } \\
8,2 \pm 1,3 \mathrm{mg} / \mathrm{L} \text { de LAS }\end{array}$ \\
\hline III & 49 & $\begin{array}{l}\text { Alimentação do reator com substrato sintético acrescido de } \\
24,4 \pm 3,7 \mathrm{mg} / \mathrm{L} \text { de LAS }\end{array}$ \\
\hline IV & 49 & $\begin{array}{l}\text { Alimentação do reator com substrato sintético acrescido de } \\
30,8 \pm 4,5 \mathrm{mg} / \mathrm{L} \text { de LAS }\end{array}$ \\
\hline V & 70 & $\begin{array}{l}\text { Alimentação do reator com substrato sintético acrescido de } \\
38,4 \pm 5,7 \mathrm{mg} / \mathrm{L} \text { de LAS }\end{array}$ \\
\hline VI & 47 & $\begin{array}{l}\text { Alimentação do reator com substrato sintético acrescido de } \\
45,8 \pm 5,4 \mathrm{mg} / \mathrm{L} \text { de LAS }\end{array}$ \\
\hline
\end{tabular}




\section{5. Análises Físico-Químicas e Cromatográficas}

Amostras do afluente e efluente dos reatores foram analisadas seguindo a frequência e parâmetros apresentados na Tabela 4.7. Foram feitas análises de pH, DQO (demanda química de oxigênio), sulfato e sulfeto de acordo com APHA (2005). A determinação de ácidos voláteis foi realizada utilizando-se metodologia descrita por Dillalo e Albertson (1961), enquanto que, a alcalinidade foi determinada por metodologia desenvolvida por Dillalo e Albertson (1961) e modificada por Ripley et al. (1986).

Tabela 4.7: Análises para monitoramento do reator de leito fluidificado

\begin{tabular}{|c|c|c|c|}
\hline Parâmetro & Método & Freqüência & Referência \\
\hline $\mathrm{pH}$ (unidade) & Potenciométrico & 2X semana & APHA (2005) \\
\hline DQO filtrada $(\mathrm{mg} / \mathrm{L})$ & Espectrofotométrico & $2 \mathrm{X}$ semana & APHA (2005) \\
\hline Sulfato $(\mathrm{mg} / \mathrm{L})$ & Turbidimétrico & $2 \mathrm{X}$ semana & APHA (2005) \\
\hline Sulfeto (mg/L) & Turbidimétrico & 2X semana & APHA (2005) \\
\hline $\begin{array}{l}\text { Alcalinidade } \\
\left(\mathrm{mg} \mathrm{CaCO}_{3} / \mathrm{l}\right)\end{array}$ & Titulométrico & $2 \mathrm{X}$ semana & $\begin{array}{c}\text { Dillalo e Albertson (1961) } \\
\text { modificada por Ripley et al. } \\
\text { (1986) }\end{array}$ \\
\hline $\begin{array}{l}\text { Ácidos voláteis } \\
\text { totais (mg HAc/L) }\end{array}$ & Titulométrico & $2 \mathrm{X}$ semana & Dillalo e Albertson (1961) \\
\hline LAS (mg/L) & $\begin{array}{l}\text { Cromatográfico } \\
\text { (HPLC) }\end{array}$ & $2 \mathrm{X}$ semana & Duarte et al. (2006) \\
\hline Vazão (mL/h) & Volumétrico & Diariamente & - \\
\hline
\end{tabular}

A concentração de LAS foi determinada por cromatografia líquida de alta eficiência (HPLC) baseado em metodologia desenvolvida e validada por Duarte et al. (2006). As amostras foram previamente filtradas para boa utilização e conservação do equipamento HPLC e durante o procedimento de validação do método, verificou-se que tal filtração não interferiu no resultado das análises. As condições cromatográficas empregadas estão descritas na Tabela 4.8 .

Tabela 4.8: Condições cromatográficas para quantificação do LAS comercial

\begin{tabular}{ll}
\hline Coluna & C-8 Supelco, $\mathbf{5} \boldsymbol{\mu m}, \mathbf{1 5} \mathbf{~ c m ~ x ~ 4 , 6 ~ m m ~}$ \\
\hline Solvente A & solução de $\mathrm{NaClO}_{4} 0,075 \mathrm{M}$ em água ultra purificada \\
Solvente B & MeOH puro \\
Fluxo & $0,5 \mathrm{~mL} /$ min \\
Detector & fluorescência, com $\lambda$ excitação $225 \mathrm{~nm}$ e $\lambda$ emissão $290 \mathrm{~nm}$ \\
Forno & $35^{\circ} \mathrm{C}$ \\
\hline
\end{tabular}


Curvas de calibração para quantificação do surfactante foram feitas com solução de LAS em concentração conhecida preparada em água ultra purificada.

Solução com concentração de 3, 5, 7, 10, 20, 30, 40 e 50 mg/L de LAS foram injetadas no HPLC e, com os seus cromatogramas (Figura 4.5) foi possível ajustar curva para cada pico dos homólogos de LAS (Figura 4.6).

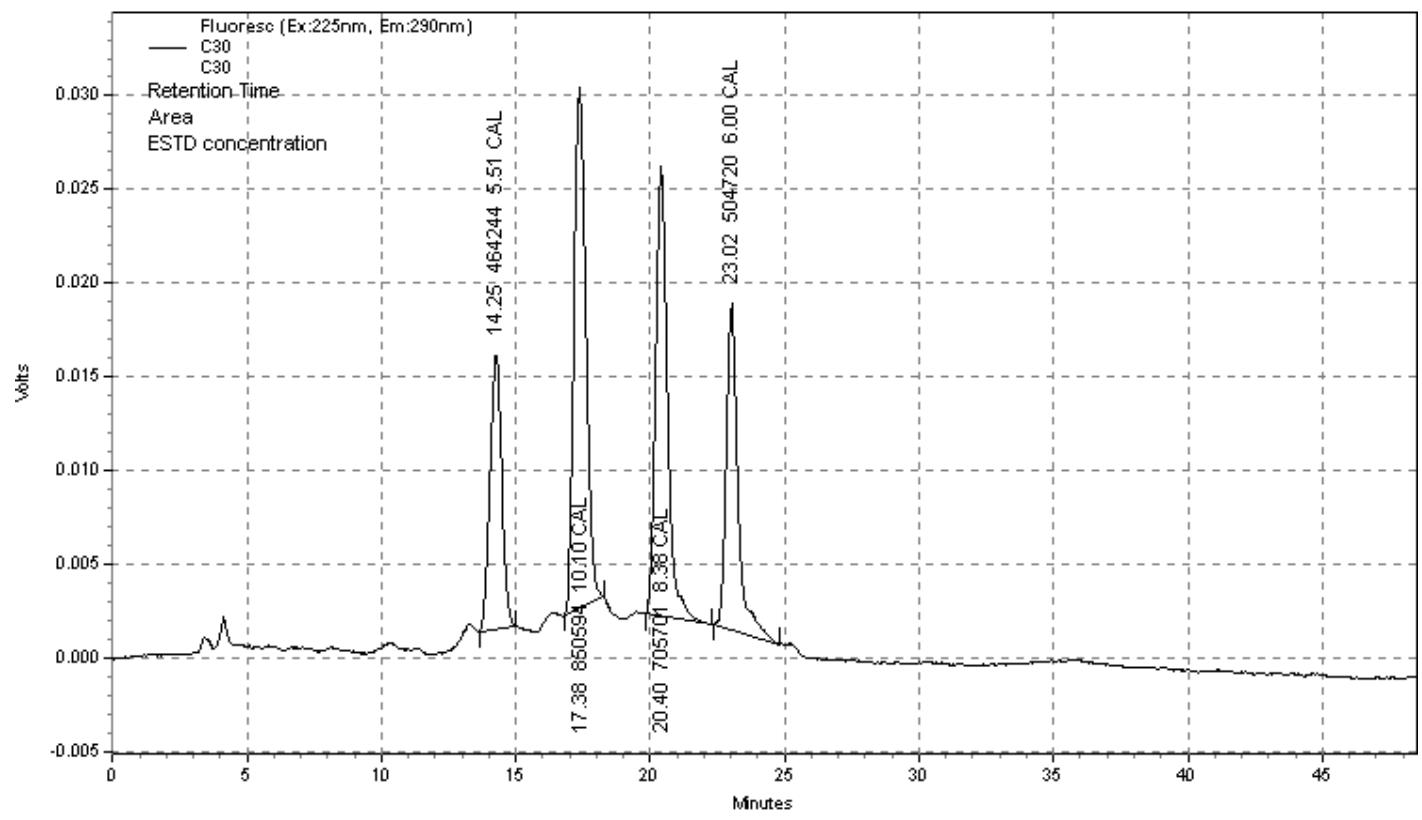

Figura 4.5: Exemplo de cromatograma de LAS - padrão $30 \mathrm{mg} / \mathrm{L}$

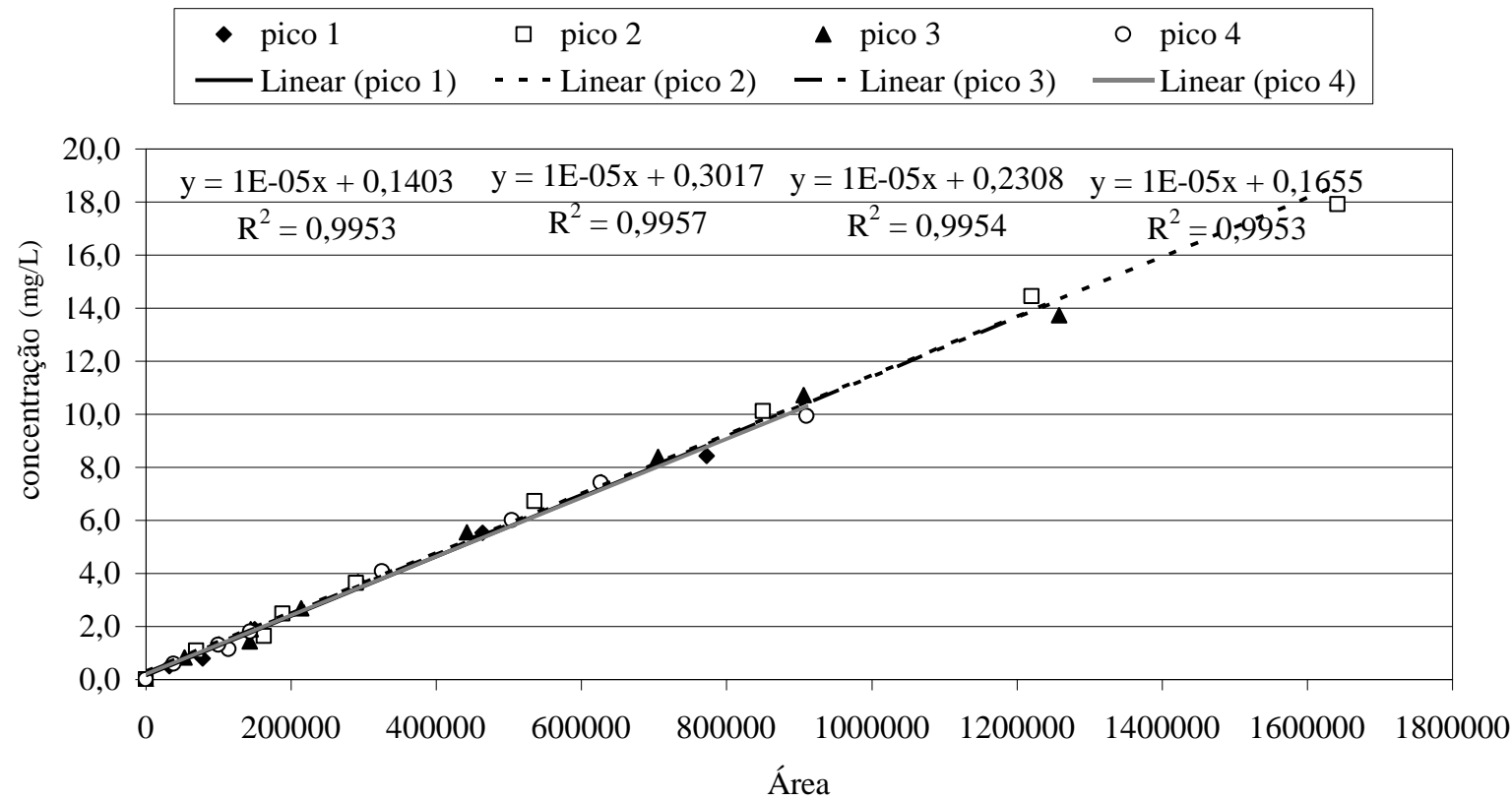

Figura 4.6: Curva de calibração de LAS para cada um dos quatro picos do cromatograma 


\subsection{Caracterização da diversidade Microbiana \\ 4.6.1. Exames Microscópicos}

Amostras dos reatores foram examinadas em microscópio Olympus BX60 de contraste de fase e fluorescência, acoplado à câmera com captura de imagem e software Image Pro Plus. Para isso, em lâminas de vidro previamente limpas com álcool, foi colocada fina camada de ágar (2\%). Após a solidificação do ágar, uma gota de amostra foi adicionada e recoberta com a lamínula.

Exames em microscópio eletrônico de varredura também foram realizados com amostras retiradas após final da operação. As amostras do biofilme foram preparadas de acordo com Varesche et al. (1997).

\subsubsection{Biologia Molecular}

\subsubsection{Extração do DNA}

A extração de DNA foi realizada por meio do método direto utilizando glass beads e mistura de fenol: clorofórmio: tampão (1: 1: $1 \mathrm{v} / \mathrm{v})$ seguindo o procedimento descrito por Griffiths et al. (2000). As reações de PCR foram realizadas utilizando primers p27F e p1100R (LANE, 1991) para o Domínio Bacteria.

Para as reações de PCR foram usados $0,4 \mu \mathrm{M}$ de primer, $200 \mu \mathrm{M}$ de dNTPs (Invitrogen), uma unidade de Taq DNA polymerase (Invitrogen) e aproximadamente $100 \mathrm{ng}$ de DNA genômico. O programa para amplificação do gene RNAr 16S seguiu as seguintes etapas: desnaturação inicial a $94{ }^{\circ} \mathrm{C}$ por 2 min; 10 ciclos de 1 minuto de desnaturação a $94{ }^{\circ} \mathrm{C}$; 30 segundos de anelamento a $69{ }^{\circ} \mathrm{C}$ e 3 minutos a $72{ }^{\circ} \mathrm{C}$ para extensão; seguido de mais 10 ciclos de 1 minuto de desnaturação a $94{ }^{\circ} \mathrm{C} ; 30$ segundos de anelamento a $63{ }^{\circ} \mathrm{C}$ e 3 minutos a $72{ }^{\circ} \mathrm{C}$ para extensçao e resfriamento final a $4{ }^{\circ} \mathrm{C}$, de acordo com Duarte (2006). 


\subsubsection{Clonagem e Sequenciamento}

As amostras dos produtos de PCR (fragmento do gene RNAr 16S) foram clonadas em plasmídeo pGEM Easy Vector System I, de acordo com as especificações do fabricante (Promega).

A etapa de adenilação foi realizada da seguinte maneira: $3 \mu \mathrm{L}$ de PCR purificado, mais $1 \mu \mathrm{L}$ de tampão com $\mathrm{MgCl}_{2}, 1 \mu \mathrm{L}$ de dATP, $1 \mu \mathrm{L}$ de Taq DNA polymerase, $4 \mu \mathrm{L}$ de água ultra purificada estéril. O material foi colocado a $70{ }^{\circ} \mathrm{C}$ por 30 minutos no termociclador. A etapa de ligação do vetor $p G E M$ foi realizada seguindo a adição dos seguintes componentes: $5 \mu \mathrm{L}-2 \mathrm{X}$ tampão de ligação rápido, $1 \mu \mathrm{L}$ do vetor $p G E M$ Easy, $2 \mu \mathrm{L}$ do produto de $\mathrm{PCR}$ adenilado, $1 \mu \mathrm{L}$ T4 DNA ligase, $1 \mu \mathrm{L}$ de água ultra purificada estéril. Misturou-se a reação com pipeta e incubou-se por 1 hora em temperatura ambiente.

Foi realizada a transformação em células competentes de E. coli que estavam armazenadas a $-80{ }^{\circ} \mathrm{C}$ e foram mantidas em banho de gelo por 5 minutos. $2 \mu \mathrm{L}$ do produto de ligação foram misturados com as células de E. coli. As células foram aquecidas em banhomaria a $42{ }^{\circ} \mathrm{C}$ dirante 50 segundos, sem agitação. Os tubos foram agitados manualmente e mantidos em banho de gelo por 2 minutos. $200 \mu \mathrm{L}$ de meio LB líquido (sem Ágar) (Tabela 4.9) foram adicionados à temperatura ambiente. Incubou-se o tubo por 45 minutos, com agitação de $150 \mathrm{rpm}$ em temperatura de $37^{\circ} \mathrm{C}$.

Tabela 4.9: Composição do Meio LB

\begin{tabular}{cc}
\hline Nutrientes & g/L \\
\hline Triptona & 10 \\
Extrato de levedura & 5 \\
$\mathrm{NaCl}$ & 5 \\
Agar & 15 \\
\hline
\end{tabular}

Em tubo Falcon foram colocados $50 \mathrm{~mL}$ de meio LB com ampicilina/IPTG/X-Gal com descrito a seguir: $28 \mu \mathrm{L}$ ampicilina (0,5 g em $10 \mathrm{~mL}$ de água), $47 \mu \mathrm{L}$ de IPTG $(23 \mathrm{mg} / \mathrm{mL})$ e $64 \mu \mathrm{L}$ de X-Gal (40 mg/mL). Esse conteúdo foi distribuído em duas placas de Petri cada uma com $25 \mathrm{~mL}$. As placas focaram em repouso por 30 mnutos antes do uso. $100 \mu \mathrm{L}$ do produto de transformação foram adicionados em cada plava e incubou-se a $37^{\circ} \mathrm{C}$ por 24 horas. Após esse período, os clones foram selecionados ao acaso e as colônias transformadas que 
receberam o inserto (colônias brancas) foram transferidas para $5 \mu \mathrm{L}$ de meio líquido $\mathrm{LB}$ acrescidas de $2,5 \mu \mathrm{L}$ de ampicilina e mantidas sob agitação a $37^{\circ} \mathrm{C}$ por aproximadamente 16 horas. As amostras foram centrifugadas e armazenadas em tampão $200 \mu \mathrm{L}$ de tampão TE.

A eficiência das reações foi verificada por eletroforese em gel de agarose $1 \%$. O DNA foi amplificado pela reação da cadeia polimerase (PCR). Foram utilizados primers M13 forward (5'-GTA AAA CGA CGG CCA G-3') e reverse (5'-CAG GGA ACA GCT ATG AC-3') (Messing, 1983). O programa de amplificação foi realizado como descrito a seguir: desnaturação inicial a $94{ }^{\circ} \mathrm{C}$ por 2 minutos, 25 ciclos de 60 segundos de desnaturação a $94{ }^{\circ} \mathrm{C}$, 60 segundos para anelamento a $55^{\circ} \mathrm{C}$ e 60 segundos de extensão a $72{ }^{\circ} \mathrm{C}$. Extensão final de 7 minutos a $72{ }^{\circ} \mathrm{C}$, e resfriamento final a $4{ }^{\circ} \mathrm{C}$.

Os fragmentos amplificados foram purificados com kit GFX PCR DAN \& Gel Band (GE Helthcare). O seqüenciamento dos nucleotídeos foi realizado em seqüenciador automático Megabace 1000 (Ge Healthcare).

\subsubsection{Análise das Sequências do fragmento do gene 16S RNAr}

As seqüências de nucleotídeos foram processadas com o programa Seqman do pacote Lasergene DNAstar para remoção do vetor.

Para a afiliação filogenética das seqüências, utilizou-se a ferramenta SEQ MATCH a fim de comparar as sequiências com os bancos de dados do Ribosomal Database Project RDP (http://rdp.cme.msu.edu/seqmatch/seqmatch_intro.jsp), que classificam as sequiências em possíveis níveis taxonômicos.

Para definição das unidades taxonômicas operacionais (UTOs) foi usado o programa DOTUR (SCHLOSS e HANDELSMAN, 2005). Para tanto, utilizou-se uma matriz de distância evolutiva calculada por meio do programa DNADIST (algoritmo do Kimura) do pacote PHYLIP 3.63 (FELSENSTEIN: http://evolution.genetics.washington.edu/phylip.html), a partir do alinhamento feito usando-se o programa ClustalX 2.0, com definições de parâmetros padrão. Os números de UTOs e de seqüências de cada UTO foram determinados considerando-se a distância evolutiva de 0,03 .

As UTOs foram alinhadas com as sequiências do banco de dados RDP no programa ClustalX 2.0. As relações filogenéticas obtidas foram analisadas pelos métodos NeighborJoining e máxima parcimônia do pacote PHYLIP 3.63. Análises de bootstrap foram baseadas em 100 reamostragens. 


\subsubsection{Técnica de Tubos Múltiplos}

A determinação do Número Mais Provável (NMP) foi realizada por meio da Técnica de Tubos Múltiplos. Essa determinação foi realizada ao final do experimento do reator em escala de bancada para quantificação dos grupos microbianos anaeróbios. A técnica consistiu na inoculação das bactérias provenientes do reator em substrato sintético idêntico a alimentação do reator com concentração de LAS de $20 \mathrm{mg} / \mathrm{L}$.

O substrato sintético foi esterilizado por filtração em membrana de $0,22 \mu \mathrm{m} \mathrm{em}$ sistema Millipore de filtração. Esse material foi previamente esterilizado em autoclave a $121^{\circ} \mathrm{C}$ e $1 \mathrm{~atm}$ durante 20 minutos. Após a filtração, o substrato sintético com LAS foi submetido a atmosfera de $\mathrm{N}_{2}(100 \%)$ durante 30 minutos. A seguir, foi adicionado $8,9 \mathrm{~mL}$ de substrato sintético estéril em frasco de antibiótico estéril de $30 \mathrm{~mL}$. Anteriormente a adição do substrato sintético, o frasco de antibiótico foi submetido a atmosfera de $\mathrm{N}_{2}$ (100\%), durante 1 minuto, para retirada de oxigênio. Após a adição do substrato sintético foi colocada a tampa de butila mantendo-se a troca de atmosfera por mais 30 segundos. Os frascos foram fechados com tampa de butila e lacre de alumínio.

Em todos os frascos (de diluição e contagem) foi adicionado $0,1 \mathrm{~mL}$ de solução redutora de sulfeto de sódio (5\%). Essa solução foi preparada sob condições de anaerobiose e esterilizada em membrana de 0,22 $\mu \mathrm{m}$ usando sistema Milipore de filtração. A solução foi acondicionada em frascos de antibióticos de $30 \mathrm{~mL}$ e mantida em temperatura ambiente no escuro.

Amostra de material suporte e fase líquida foi retirada do reator pelo segundo ponto de amostragem (considerando o primeiro ponto como o mais próximo da base do reator) ao final da operação, com alimentação de 45,8 $\pm 5,4 \mathrm{mg} / \mathrm{L}$ de LAS. O material foi transferido para frasco de antibiótico contendo $5 \%(\mathrm{v} / \mathrm{v})$ de pérolas de vidro e submetido a atmosfera de $\mathrm{N}_{2}$ (100\%) durante 15 minutos. O frasco foi fechado com tampa de butila e lacre de alumínio e

agitado por tempo suficiente (cerca de 30 minutos) para que, visualmente, a biomassa se desprendesse do suporte e passasse para a fase líquida a fim de ser coletada com seringa.

Após o processamento da amostra para a liberação das células foi transferido $1,0 \mathrm{ml}$ para o primeiro frasco de antibiótico com substrato sintético, em ambiente de assepsia (próximo a chama do bico de Bunsen). Realizou-se a homogeneização da amostra manualmente. Em seguida, retirou-se $1 \mathrm{~mL}$ dessa amostra diluída $\left(10^{-1}\right)$ e adicionou-se no próximo frasco $\left(10^{-2}\right)$. Esse procedimento foi repetido até a diluição $10^{-13}$. 
O procedimento das diluições e as inoculações da amostra em meio específico encontra-se esquematizado na Figura 4.7.

A seguir foi transferido $1,0 \mathrm{~mL}$ da amostra previamente diluída, sob ambiente de assepsia e condições de anaerobiose (nitrogênio 100\%), em cada frasco de antibiótico com substrato sintético e LAS. Para cada diluição foi usado 5 frascos (quintuplicatas).

Os frascos de contagem (quintuplicata das diluições de $10^{-1}$ a $10^{-13}$ ) foram mantidos em condições anaeróbias e a $30^{\circ} \mathrm{C}$ por 30 dias. Após este período de incubação foi constatado o crescimento dos seguintes grupos microbianos: (1) bactérias anaeróbias totais - avaliadas pela turvação do meio reacional, (2) arquéias metanogênicas - determinadas pela injeção de biogás de cada frasco da contagem em cromatógrafo gasoso (formação de metano) e (3) bactérias redutoras de sulfato (BRS) - determinadas pela produção de sulfeto de hidrogênio.

Metano foi medido em cromatógrafo gasoso (Gow-Mac com detector de condutividade térmica e coluna PorapakQ - $2 \mathrm{~m} \mathrm{x} \mathrm{1/4} \mathrm{in} \mathrm{80-100} \mathrm{mesh).} \mathrm{As} \mathrm{temperaturas} \mathrm{do}$ injetor, forno e detector foram $50{ }^{\circ} \mathrm{C}, 50^{\circ} \mathrm{C}$ e $80{ }^{\circ} \mathrm{C}$, respectivamente. Hidrogênio foi usado como gás de arraste (60 mL/min).

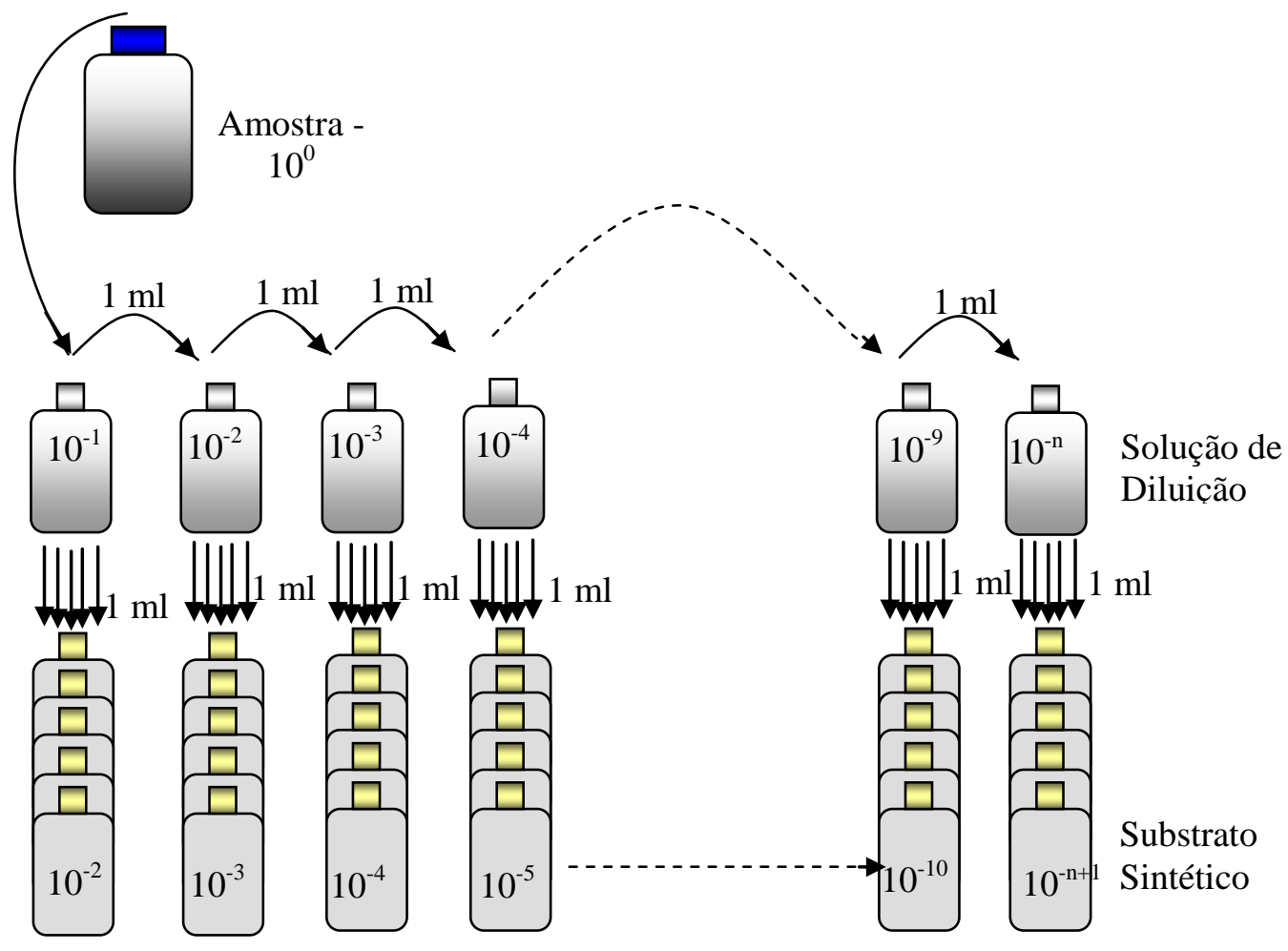

Figura 4.7: Esquema das diluições e inoculações do método NMP 
A verificação da presença de sulfeto na amostra ocorreu adicionando-se uma gota da fase líquida, de cada frasco de contagem, em papel de filtro embebido em solução de acetato de chumbo e seco em estufa, conforme metodologia desenvolvida por Sakamoto (1996).

A solução indicadora da presença de sulfeto de hidrogênio foi preparada dissolvendose $2 \mathrm{~g}$ de acetato de chumbo em $18 \mathrm{ml}$ de água ultrapurificada. Gotas de ácido acético foram adicionadas até a solução tornar-se transparente.

O sulfeto produzido pelas BRS pode reagir com o chumbo presente no papel de filtro formando precipitado negro $(\mathrm{PbS})$ de acordo com as reações a seguir:

$$
\begin{gathered}
\mathrm{Pb}\left(\mathrm{C}_{2} \mathrm{H}_{3} \mathrm{O}_{2}\right)_{2}+\mathrm{Na}_{2} \mathrm{~S} \longrightarrow \mathrm{PbS}+2 \mathrm{Na}+2 \mathrm{C}_{2} \mathrm{H}_{3} \mathrm{O}_{2} \\
\mathrm{~Pb}\left(\mathrm{C}_{2} \mathrm{H}_{3} \mathrm{O}_{2}\right)_{2}+\mathrm{H}_{2} \mathrm{~S} \longrightarrow \mathrm{PbS}+2 \mathrm{CH}_{3} \mathrm{COOH}
\end{gathered}
$$

O limite de detecção da presença de sulfeto para a solução de acetato de chumbo é de $10 \mathrm{mg} / \mathrm{L}$. A estimativa da população de BRS é positiva nos frascos que apresentarem precipitado negro, e aqueles que não apresentam são denominados de negativos (Sakamoto, 1996).

Combinações de respostas positivas foram a base do cálculo para estimar o NMP, usando a tabela padrão de probabilidade (APHA, 2005), que confere o limite de confiança de 95\% para cada valor determinado.

Foi consultada a tabela padrão de probabilidade (APHA, 2005) e obtiveram-se os valores para equação de determinação do número mais provável:

$$
N M P(\text { tabelaAPHA }) \times \frac{10}{10^{y}}=N M P[\text { celulas } / 100 \mathrm{ml}]
$$

Sendo:

y = menor diluição da série de combinações selecionadas.

Foi realizada a quantificação em NMP /g STV. A análise de sólidos totais voláteis foi realizada segundo APHA (2005).

\subsection{Avaliação do Potencial Redox}

A constatação de potencial redox foi realizada através de método indireto, conforme protocolo desenvolvido no Laboratório de Processos Biológicos (LPB - EESC/USP). Esse método se baseia na diferenciação colorimétrica do corante resazurina conforme o potencial 
redox do meio. A cor azul é característica de aerobiose e a cor branca corresponde à anaerobiose estrita. A cor rosa é característica de meios com potencial redox entre 200 e $-200 \mathrm{mV}$, podendo ser relacionada à condições anaeróbias.

O experimento consistiu na adição do corante resazurina $0,1 \%$ na alimentação do reator, na proporção $1 \mathrm{~mL} / \mathrm{L}$. O frasco com alimentação já acrescida de resazurina foi submetido a atmosfera de $\mathrm{N}_{2}(100 \%)$ durante aproximadamente $30 \mathrm{~min}$ e em seguida transferido para alimentação do reator. 


\section{RESULTADOS E DISCUSSÃO}

\subsection{Ensaio de Adsorção no Material Suporte}

Ensaios de adsorção em batelada, sem biomassa anaeróbia, foram realizados para cada suporte separadamente e em duplicata (Figura 4.4).

A concentração de LAS foi monitorada na fase líquida por 24 horas em intervalos regulares de tempo. Os resultados estão apresentados na Tabela 5.1.

Tabela 5.1: Concentração média de LAS na fase líquida ao longo do tempo

\begin{tabular}{ccccc}
\hline $\begin{array}{c}\text { Tempo } \\
(\mathbf{h})\end{array}$ & $\begin{array}{c}\text { Carvão ativado } \\
(\mathbf{m g} / \mathbf{L})\end{array}$ & $\begin{array}{c}\text { Argila } \\
\text { expandida } \\
(\mathbf{m g} / \mathbf{L})\end{array}$ & $\begin{array}{c}\text { Pérolas de vidro } \\
(\mathbf{m g} / \mathbf{L})\end{array}$ & $\begin{array}{c}\text { Areia } \\
(\mathbf{m g} / \mathbf{L})\end{array}$ \\
\hline 0,00 & $25,0 \pm 0,7$ & $25,0 \pm 1,4$ & $18,0 \pm 0,8$ & $17,7 \pm 1,0$ \\
1,00 & $16,4 \pm 3,0$ & $12,2 \pm 1,1$ & $21,1 \pm 0,1$ & $15,7 \pm 3,2$ \\
2,00 & $18,2 \pm 0,3$ & $16,2 \pm 3,8$ & $19,7 \pm 0,4$ & $14,3 \pm 2,7$ \\
3,00 & $18,5 \pm 1,1$ & $13,1 \pm 0,9$ & $19,9 \pm 0,5$ & $18,4 \pm 0,6$ \\
4,00 & $20,0 \pm 1,9$ & $13,3 \pm 0,5$ & $20,1 \pm 1,0$ & $18,5 \pm 1,5$ \\
6,00 & $21,0 \pm 0,0$ & $13,8 \pm 0,8$ & $20,1 \pm 1,6$ & $21,7 \pm 2,4$ \\
8,00 & $21,9 \pm 1,3$ & $23,0 \pm 4,2$ & $18,2 \pm 0,3$ & $19,5 \pm 1,2$ \\
24,00 & $19,1 \pm 0,7$ & $18,5 \pm 0,7$ & $20,5 \pm 2,5$ & $16,1 \pm 2,1$ \\
\hline
\end{tabular}

As Figuras Figura 5.1 a Figura 5.4 apresentam a concentração de LAS na fase líquida em função do tempo. 


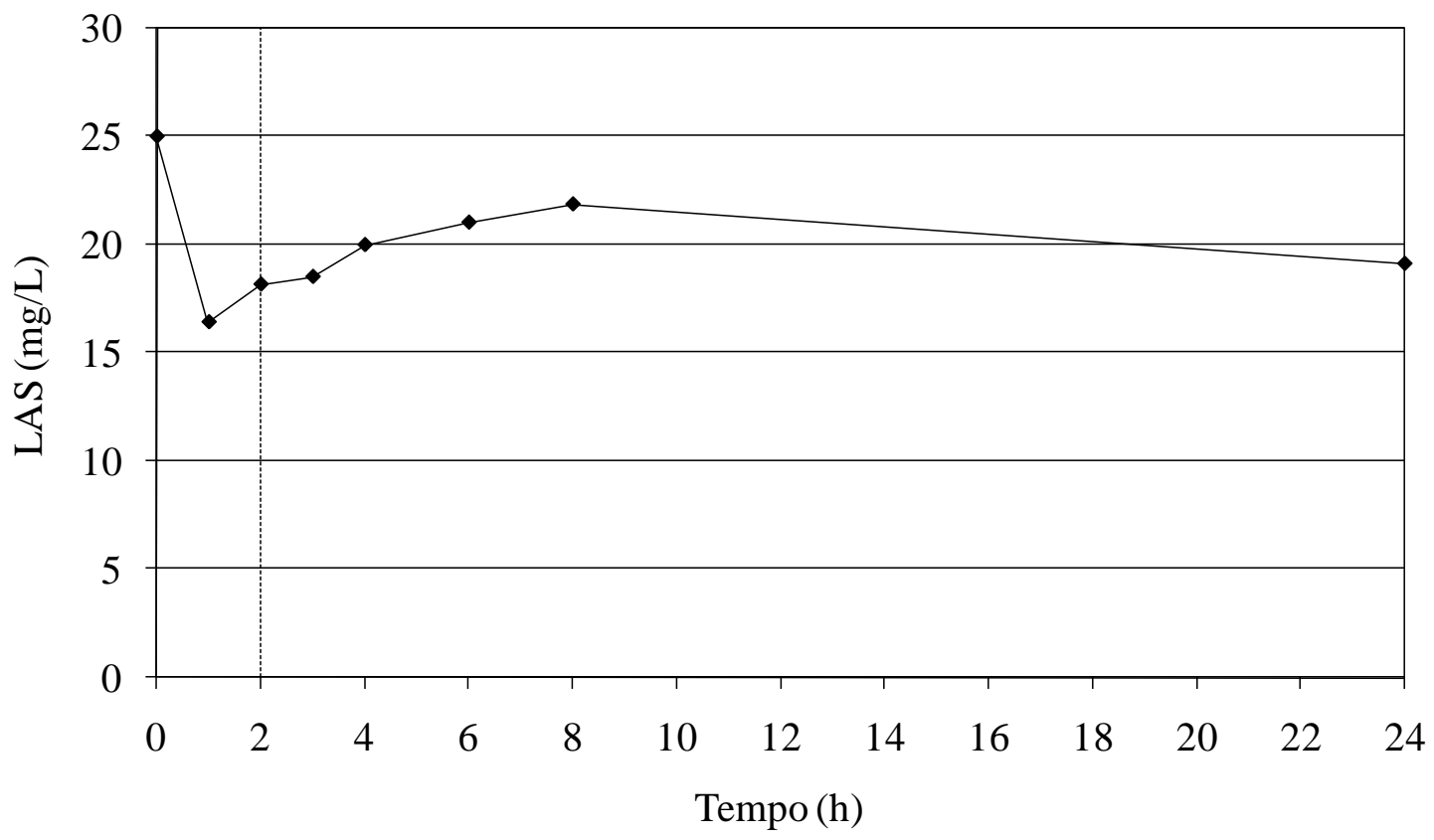

Figura 5.1: Variação da concentração de LAS ao longo do tempo em ensaios de adsorção em batelada em carvão ativado

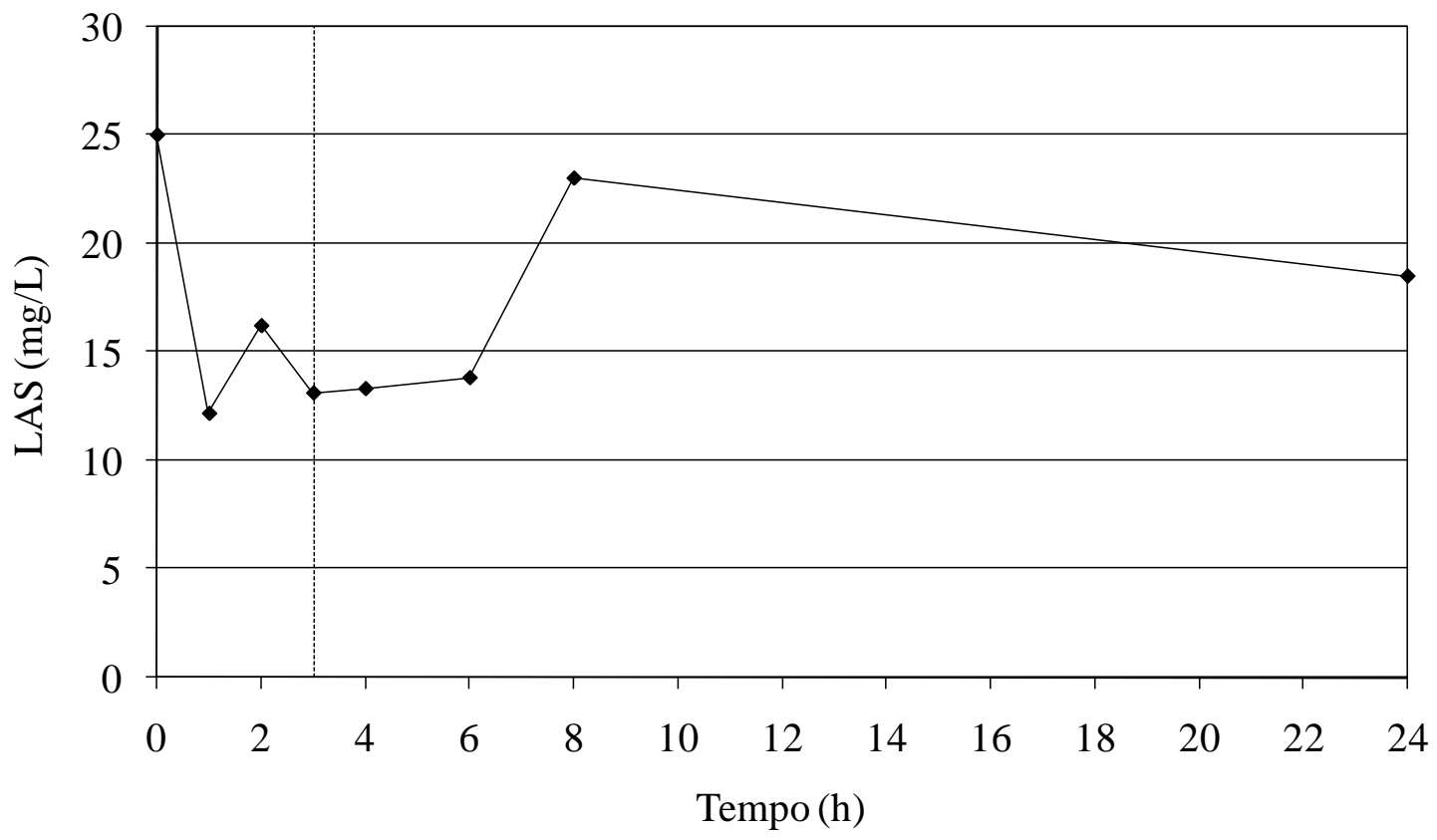

Figura 5.2: Variação da concentração de LAS ao longo do tempo em ensaios de adsorção em batelada em argila expandida 


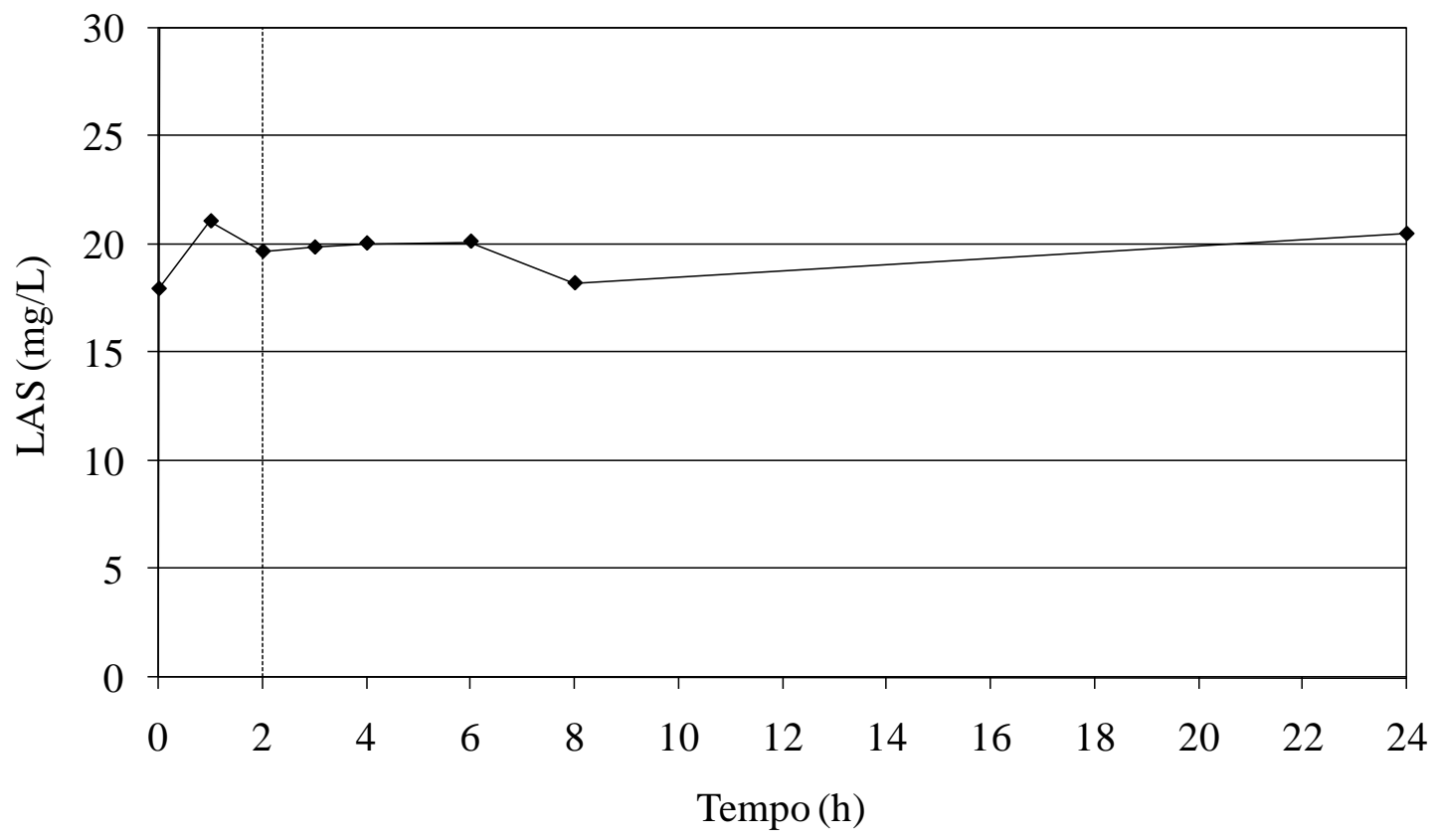

Figura 5.3: Variação da concentração de LAS ao longo do tempo em ensaios de adsorção em batelada em pérolas de vidro

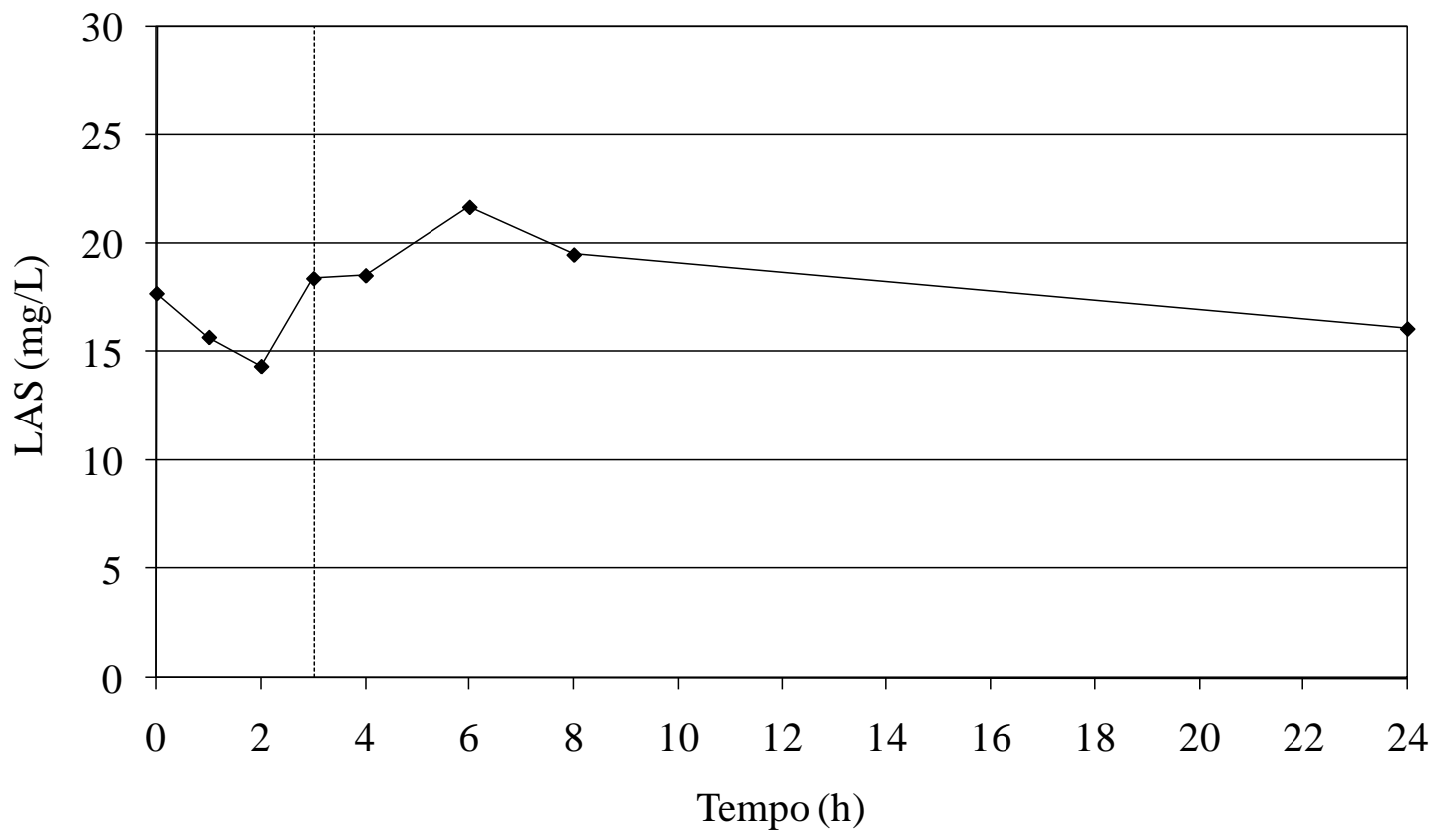

Figura 5.4: Variação da concentração de LAS ao longo do tempo em ensaios de adsorção em batelada em areia

Pode-se observar, para todos os suportes, que no início do ensaio a concentração de LAS na fase líquida oscilou até atingir um equilíbrio. O tempo para alcançar tal 
equilíbrio variou de acordo com o suporte e está representado em cada uma das figuras anteriores por linhas tracejadas verticais.

Para o carvão ativado, em duas horas de ensaio a solução já havia atingido o equilíbrio em 19,8 mg/L. Para os ensaios de adsorção realizados com argila expandida, o tempo de contato até o equilíbrio foi de 3 horas. O valor considerado foi 16,4 mg/L na solução. Quanto às pérolas de vidro, o comportamento foi mais estável e se manteve praticamente o tempo todo constante em 19,7 mg/L. Para os cálculos foi considerado equilíbrio a partir da segunda hora do ensaio. E, finalmente, para o teste do material suporte areia, o comportamento foi semelhante ao da argila expandida; ou seja, 3 horas para atingir equilíbrio de $18,8 \mathrm{mg} / \mathrm{L}$.

A massa de LAS adsorvida foi calculada através de balanço de massa (Tabela 5.2) considerando a concentração da solução inicial e a concentração média de LAS no equilíbrio do sistema. Tal cálculo tornou possível estabelecer relação entre a quantidade de LAS adsorvida por massa de material suporte e a porcentagem de LAS adsorvido.

Tabela 5.2: Balanço de massa de LAS em ensaio de adsorção

\section{Massa de LAS (mg)}

\begin{tabular}{cccccc}
\hline Suporte & Inicial & Equilíbrio & Adsorvida & $\begin{array}{c}\text { mg LAS / } \\
\text { g suporte }\end{array}$ & $\begin{array}{c}\text { LAS } \\
\text { adsorvido } \\
(\%)\end{array}$ \\
\hline Carvão ativado & 12,5 & 9,9 & 2,6 & 0,22 & 21 \\
Argila expandida & 12,5 & 8,2 & 4,3 & 0,43 & 35 \\
Pérola de vidro & 9,0 & 9,9 & 0 & 0 & 0 \\
Areia & 8,9 & 9,4 & 0 & 0 & 0 \\
\hline
\end{tabular}

Pérolas de vidro e areia são suportes que não adsorvem o surfactante LAS, ao contrário do carvão ativado e argila expandida que adsorveram 0,22 e 0,43 mgLAS/g suporte, respectivamente.

Em ensaios semelhantes realizados por Oliveira (2006) os materiais suporte testados foram espuma de poliuretano, carvão vegetal e argila expandida de diferente lote, forma e tamanho da argila empregada neste trabalho. Os resultados obtidos mostraram que a espuma de poliuretano foi o suporte com maior capacidade de adsorção do surfactante $(3,12 \mathrm{mg}$ LAS / g suporte no equilíbrio) seguido pelo carvão vegetal (0,15 mg LAS/g suporte) e argila expandida ( 0,07 mg LAS / g suporte), também no equilíbrio. Como os valores obtidos neste trabalho foram menores quando comparados a adsorção que ocorreu na espuma de poliuretano, espera-se que a remoção 
do LAS em reatores preenchidos com tais materiais suporte seja devido a degradação biológica.

\subsection{Eficiência do Método de Extração}

Ensaios com os materiais suporte para determinação da eficiência do método de extração mostraram que $93,7 \%$ e 99,8\% da massa de LAS adsorvida no carvão ativado e argila expandida foram recuperadas através da extração, respectivamente.

Análises da solução inicial e do sobrenadante após 24 horas de contato da solução de LAS com as pérolas de vidro indicaram não haver adsorção alguma nesse material.

Os resultados deste ensaio estão apresentados na Tabela 5.3.

Tabela 5.3: Resultados do ensaio de adsorção

\begin{tabular}{lccccc}
\hline Material Suporte & & & \multicolumn{3}{c}{ LAS (mg/L) } \\
\hline & $\begin{array}{c}\text { Massa } \\
\text { total (g) }\end{array}$ & $\begin{array}{c}\text { Massa } \\
\text { extraída }(\mathbf{g})\end{array}$ & $\begin{array}{c}\text { Solução } \\
\text { inicial }\end{array}$ & $\begin{array}{c}\text { Sobrenadante } \\
\text { após 24 h }\end{array}$ & Extraído \\
\hline Carvão ativado & 5,14 & 1,07 & 23,1 & 16,6 & 12,3 \\
Carvão ativado & 5,22 & 1,05 & 23,1 & 16,4 & 12,6 \\
Argila expandida & 5,30 & 1,02 & 23,1 & 20,0 & 5,9 \\
Argila expandida & 5,06 & 1,03 & 23,1 & 20,2 & 5,8 \\
Pérola de vidro & 5,30 & 1,03 & 23,1 & 22,9 & - \\
Pérola de vidro & 5,12 & 1,00 & 23,1 & 23,4 & - \\
\hline
\end{tabular}

\subsection{Velocidade Mínima de Fluidificação}

\subsubsection{Pérolas de Vidro}

Para o ensaio de determinação da velocidade mínima de fluidificação das pérolas de vidro foram usados $514 \mathrm{~g}$ de material suporte, estabelecendo altura inicial do leito empacotado de $15 \mathrm{~cm}$ e porosidade de 0,19 . O diâmetro médio das partículas utilizadas foi de $1,55 \mathrm{~mm}$.

A Tabela 5.4 apresenta os valores calculados da vazão média (Q), velocidade ascensional (v) e variação de pressão $(\Delta \mathrm{P})$ de acordo com as equações 4.3 e 4.4 . 
Tabela 5.4: Valores calculados para determinação da velocidade mínima de fluidificação das pérolas de vidro

\begin{tabular}{ccc}
\hline $\mathbf{Q}\left(\mathbf{c m}^{3} / \mathbf{s}\right)$ & $\mathbf{v}(\mathbf{c m} / \mathbf{s})$ & $\Delta \mathbf{P}\left(\mathbf{g} / \mathbf{c m}_{\mathbf{.}} \mathbf{s}^{\mathbf{}}\right)$ \\
\hline 2,88 & 0,15 & 1.562 \\
4,07 & 0,21 & 3.016 \\
15,43 & 0,79 & 5.655 \\
26,23 & 1,34 & 8.994 \\
37,52 & 1,91 & 11.418 \\
41,24 & 2,10 & 11.741 \\
77,92 & 3,97 & 12.064 \\
97,51 & 4,97 & 11.848 \\
151,71 & 7,73 & 11.956 \\
194,25 & 9,89 & 11.741 \\
\hline
\end{tabular}

A velocidade mínima de fluidificação experimental para as pérolas de vidro foi determinada graficamente como mostra a Figura 5.5.

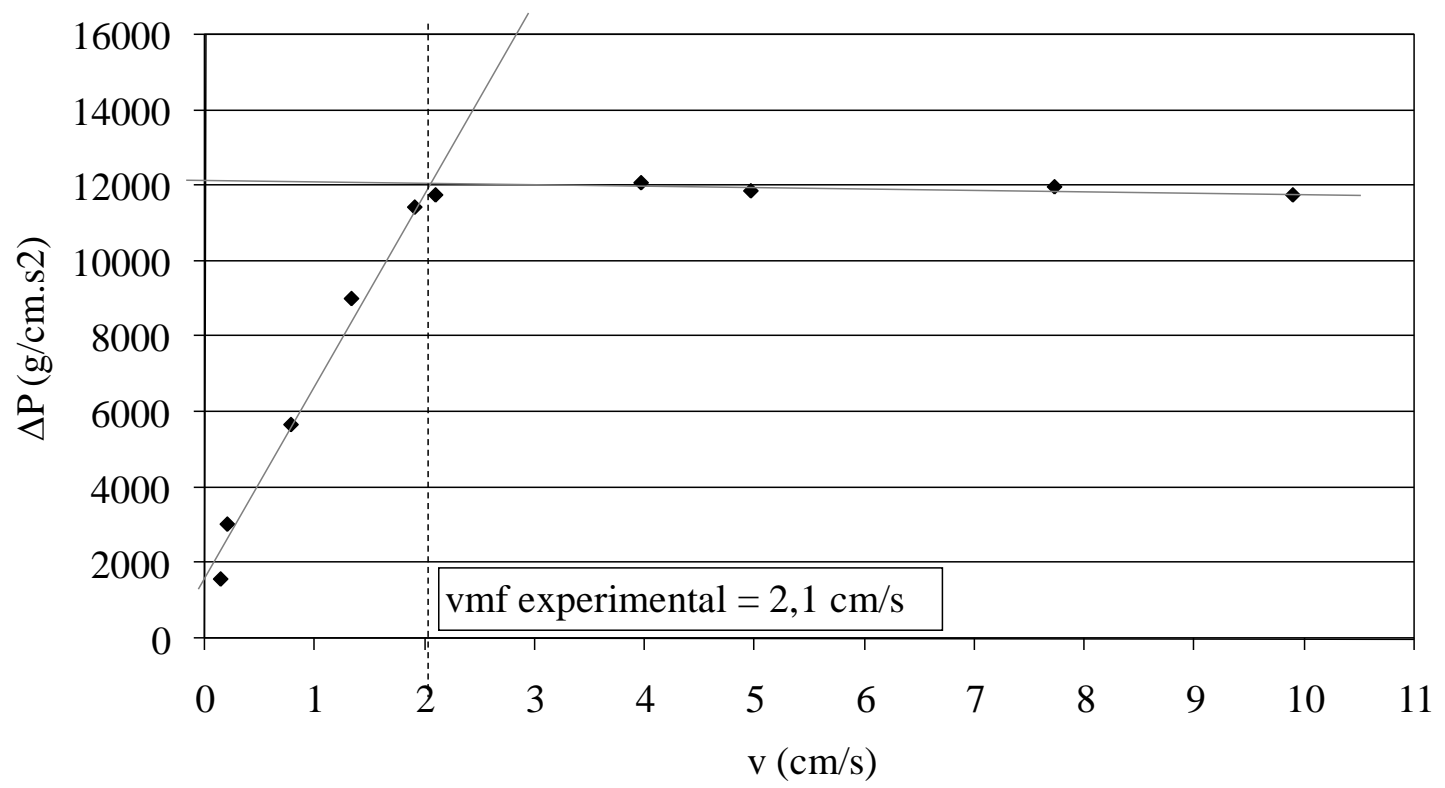

Figura 5.5: Curva característica de fluidificação para determinação gráfica da velocidade mínima de fluidificação experimental das pérolas de vidro

Os resultados obtidos mostraram que a velocidade mínima de fluidificação do material suporte pérolas de vidro foi de, aproximadamente, $2,10 \mathrm{~cm} / \mathrm{s}$. 


\subsubsection{Carvão Ativado}

Para o ensaio de determinação da velocidade mínima de fluidificação do carvão ativado foram usados $180 \mathrm{~g}$ de material suporte, estabelecendo altura inicial do leito empacotado de $9,8 \mathrm{~cm}$ e porosidade de 0,48 . O diâmetro médio das partículas utilizadas foi de $1,55 \mathrm{~mm}$.

Os dados analisados estão apresentados na Tabela 5.5

Tabela 5.5: Valores calculados para determinação da velocidade mínima de fluidificação do carvão ativado

\begin{tabular}{ccc}
\hline $\mathbf{Q}\left(\mathbf{c m}^{\mathbf{3}} / \mathbf{s}\right)$ & $\mathbf{v}(\mathbf{c m} / \mathbf{s})$ & $\Delta \mathbf{P}\left(\mathbf{g} / \mathbf{c m}_{\mathbf{.}} \mathbf{s}^{\mathbf{2}}\right)$ \\
\hline 2,51 & 0,13 & 1.723 \\
5,45 & 0,28 & 2.962 \\
5,72 & 0,29 & 3.231 \\
8,63 & 0,44 & 8.832 \\
18,17 & 0,93 & 9.425 \\
41,94 & 2,14 & 9.694 \\
62,23 & 3,17 & 10.233 \\
66,09 & 3,37 & 11.094 \\
\hline
\end{tabular}

A velocidade mínima de fluidificação experimental para o carvão ativado foi determinada graficamente como mostra a Figura 5.6.

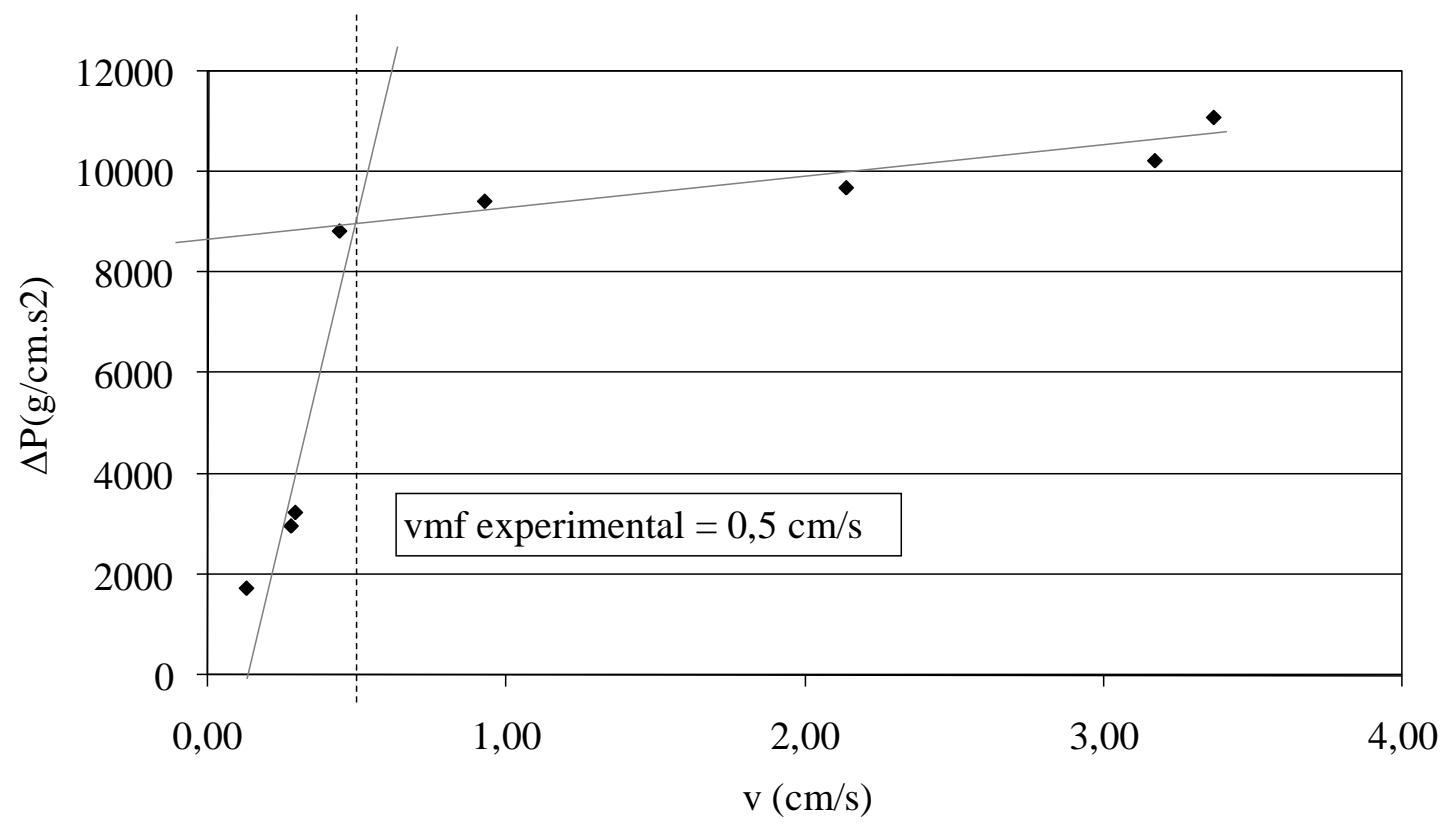

Figura 5.6: Curva característica de fluidificação para determinação gráfica da velocidade mínima de fluidificação experimental do carvão ativado 
Os resultados obtidos mostraram que a velocidade mínima de fluidificação do material suporte carvão ativado foi de, aproximadamente, $0,50 \mathrm{~cm} / \mathrm{s}$.

\subsubsection{Argila Expandida}

Para o ensaio de determinação da velocidade mínima de fluidificação da argila expandida foram usados $133 \mathrm{~g}$ de material suporte, estabelecendo altura inicial do leito empacotado de $12 \mathrm{~cm}$ e porosidade de 0,58 . O diâmetro médio das partículas utilizadas foi de 2,4 mm. Os dados analisados estão apresentados na Tabela 5.6.

Tabela 5.6: Valores calculados para determinação da velocidade mínima de fluidificação da argila expandida

\begin{tabular}{ccc}
\hline $\mathbf{Q}\left(\mathbf{c m}^{\mathbf{3}} / \mathbf{s}\right)$ & $\mathbf{v}(\mathbf{c m} / \mathbf{s})$ & $\Delta \mathbf{P}\left(\mathbf{g} / \mathbf{c m}_{\mathbf{.}} \mathbf{2}^{\mathbf{2}}\right)$ \\
\hline 2,16 & 0,11 & 592 \\
15,70 & 0,80 & 3.716 \\
22,53 & 1,15 & 5.386 \\
34,23 & 1,74 & 5.924 \\
48,80 & 2,49 & 5.816 \\
69,30 & 3,53 & 5.547 \\
88,65 & 4,52 & 5.493 \\
99,01 & 5,04 & 5.332 \\
\hline
\end{tabular}

A velocidade mínima de fluidificação experimental para a argila expandida foi determinada graficamente como mostra a Figura 5.7. 


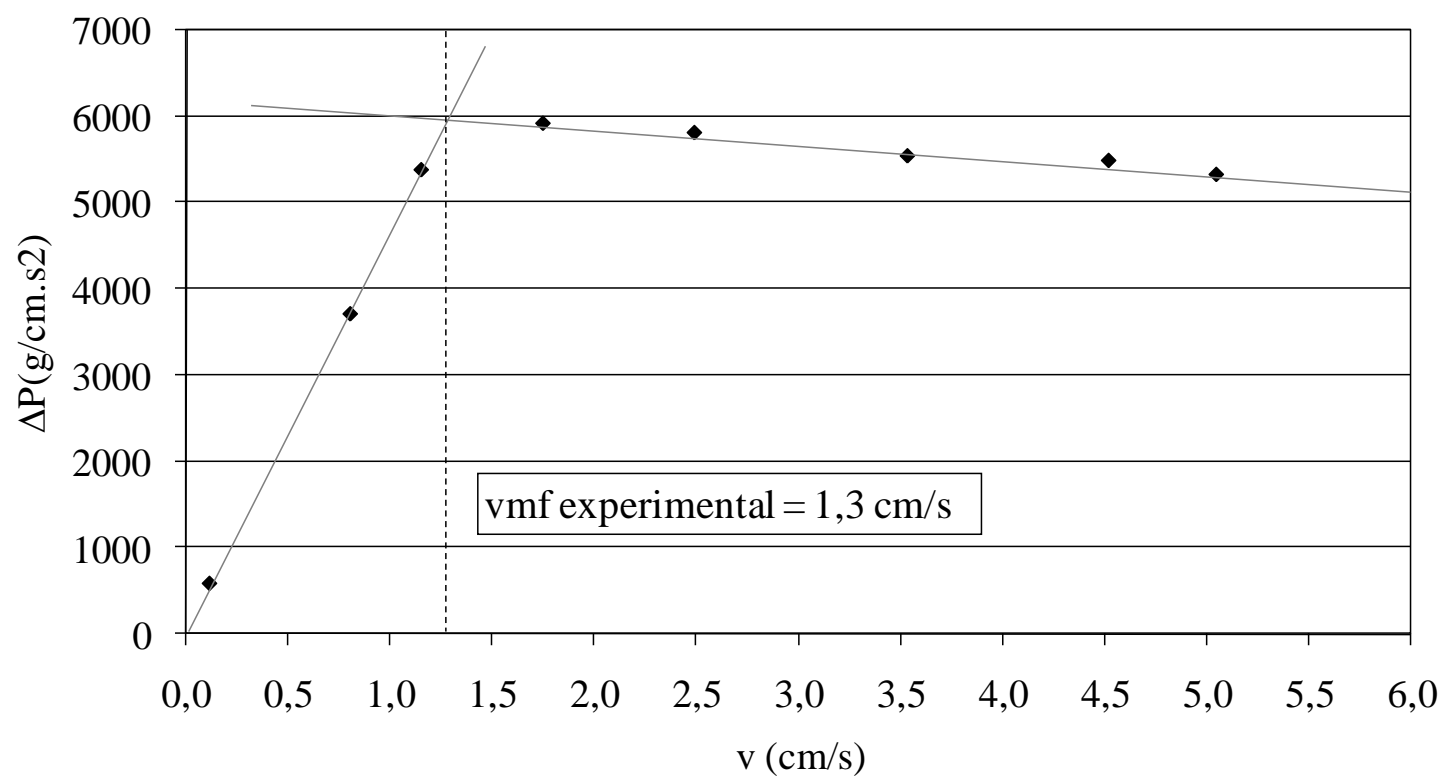

Figura 5.7: Curva característica de fluidificação para determinação gráfica da velocidade mínima de fluidificação experimental da argila expandida

Os resultados obtidos mostraram que a velocidade mínima de fluidificação do material suporte argila expandida foi de, aproximadamente, $1,3 \mathrm{~cm} / \mathrm{s}$.

\subsection{Operação e Monitoramento dos Reatores Anaeróbios de Leito Fluidificado em Menor Escala}

\subsubsection{Inóculo}

O inóculo utilizado no reator foi lodo anaeróbio proveniente de reator UASB utilizado no tratamento de dejetos de suinocultura na qual se observaram valores médios de aproximadamente $48 \mathrm{~g} / \mathrm{L}$ de sólidos totais, $36 \mathrm{~g} / \mathrm{L}$ de sólidos totais voláteis e $12 \mathrm{~g} / \mathrm{L}$ de sólidos totais fixos. Nesse lodo verificou-se variedade morfológica, por meio de análises de microscopia óptica, com presença de Methanosaeta sp., bacilos, bacilos curvos, e cocos entre outros (Figura 5.8). 


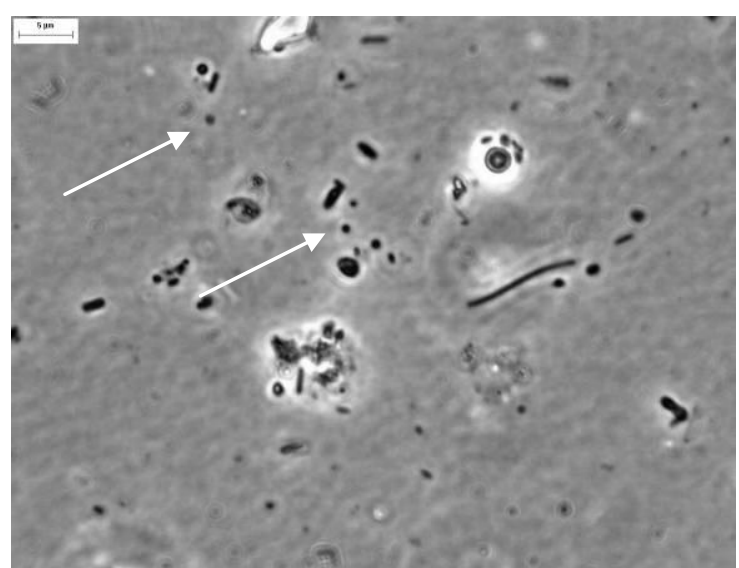

(a)

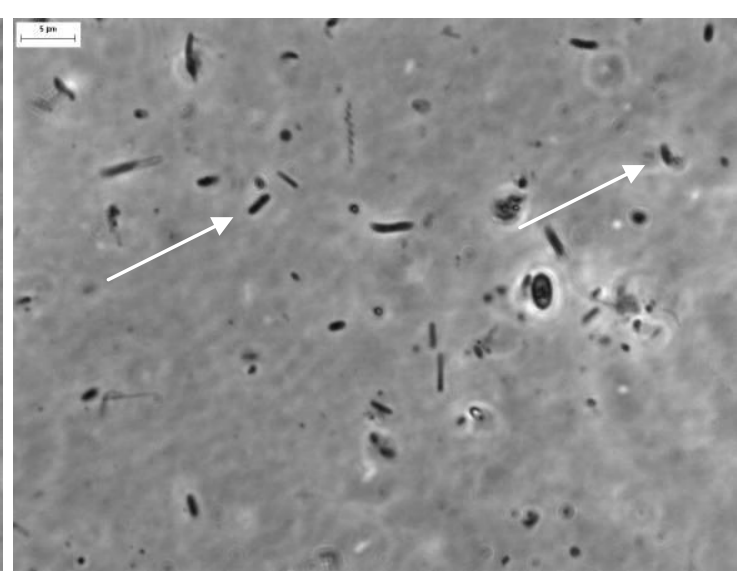

(b)

Figura 5.8: Microscopia óptica de contraste de fase das morfologias observadas no inóculo: (a) cocos, (b) bacilos retos e bacilos curvos

\subsubsection{Imobilização e Adaptação da Biomassa}

As etapas de operação dos reatores foram determinadas de acordo com a composição do substrato sintético e materiais suporte utilizados conforme mostrado anteriormente na Tabela 4.5 .

Durante as etapas de operação I e IV, os reatores foram mantidos em circuito fechado para imobilização e adaptação da biomassa ao substrato sintético. Nesta fase foram preparados $3 \mathrm{~L}$ de alimentação para cada reator que consistiu em substrato sintético (Tabela 4.3 e Tabela 4.4) e lodo anaeróbio (10\% em volume). DQO filtrada foi monitorada diariamente e os resultados estão apresentados na Figura 5.9 e Figura 5.10. As linhas verticais tracejadas referem-se aos dias de suplementação de substrato sintético em função do tempo. 


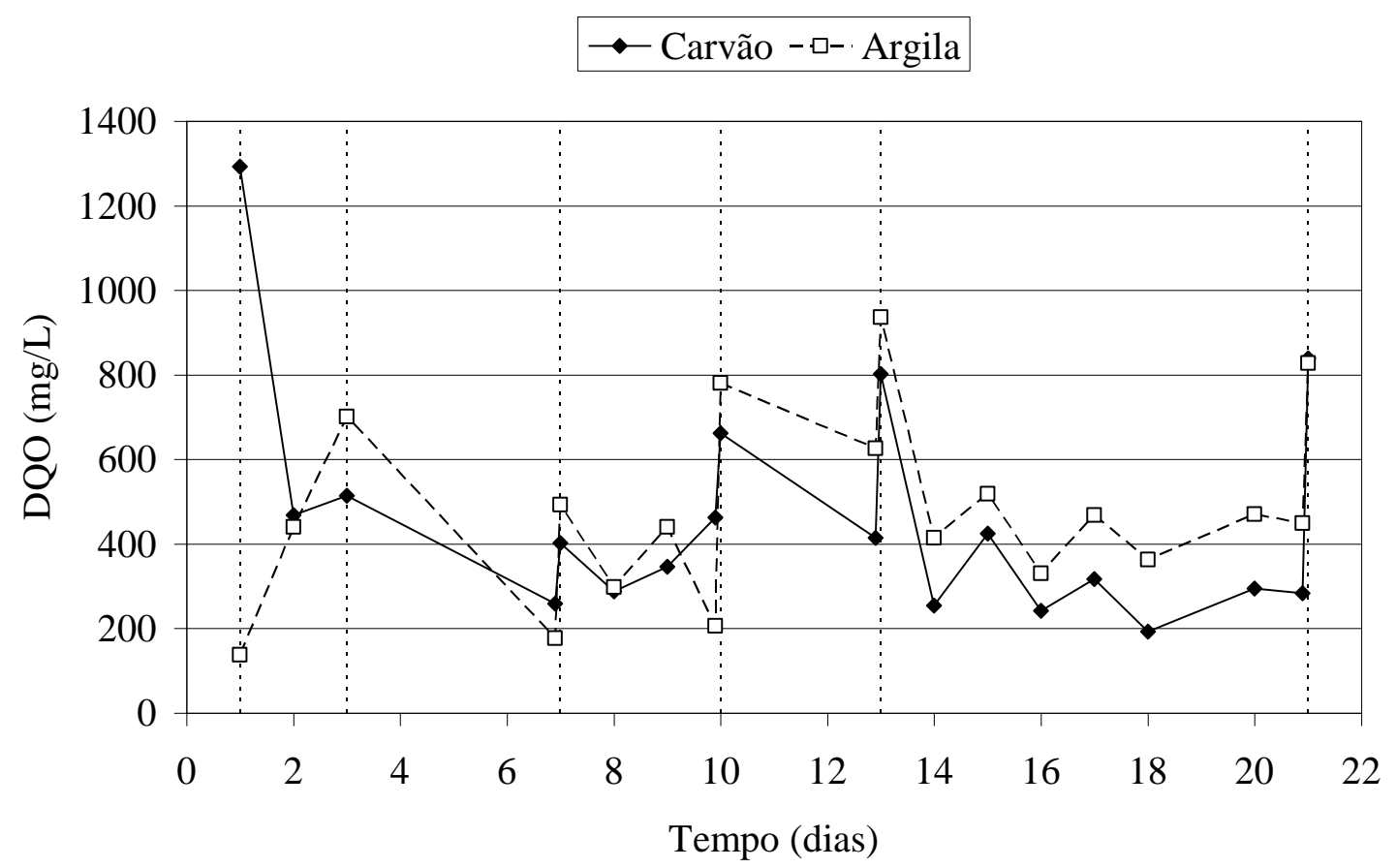

Figura 5.9: Variação temporal da DQO filtrada (etapa I)

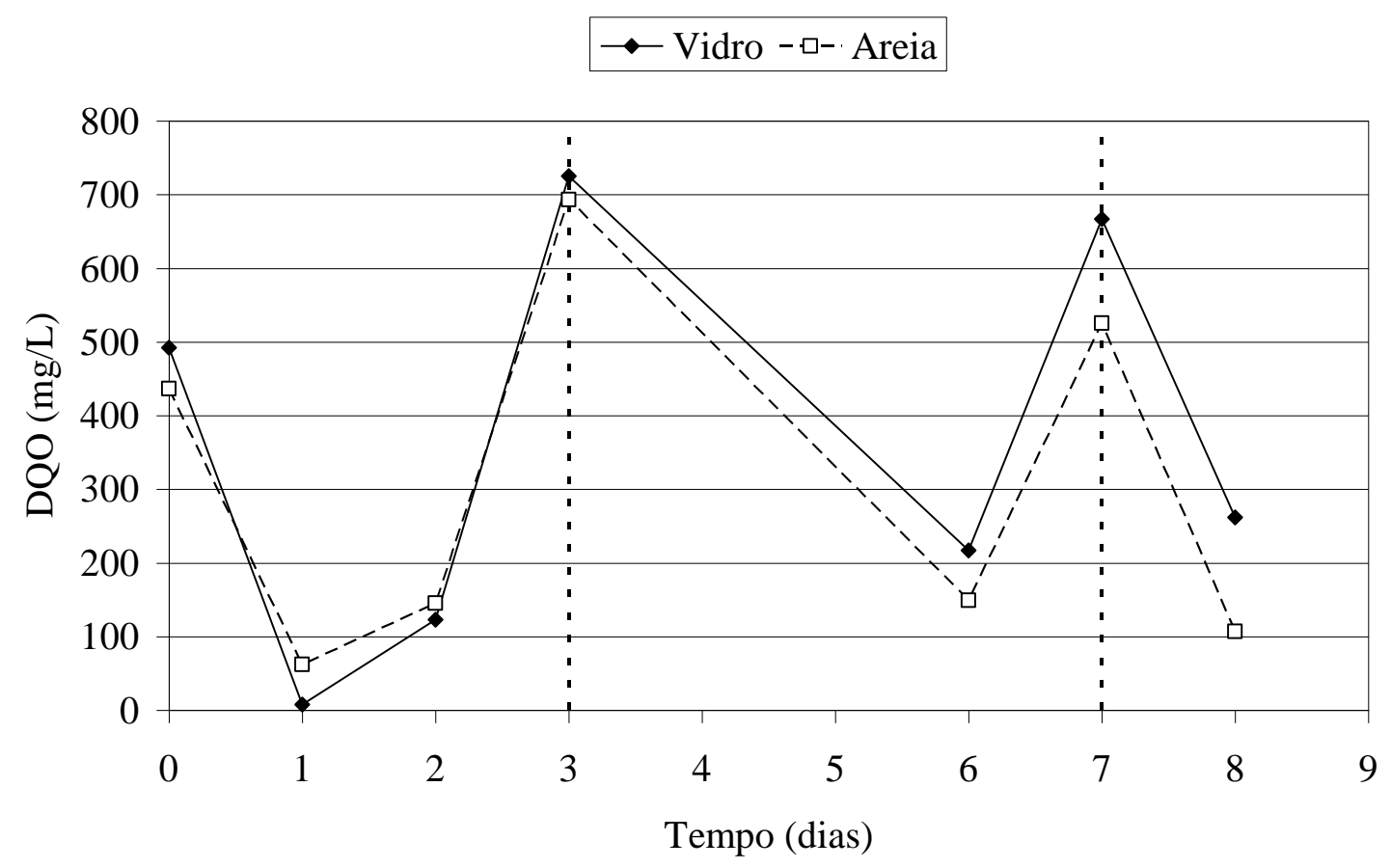

Figura 5.10: Variação temporal da DQO filtrada (etapa IV)

Conforme mencionado anteriormente, a diferença de duração entre as etapas deveu-se ao maior período necessário para aprendizagem da utilização do sistema de leito fluidificado (etapa I). Da mesma maneira, a quantidade de análises realizadas 
(pontos nos gráficos) foi maior na etapa I para observação do comportamento do sistema. No início, os valores de DQO também variaram muito $(1300 \mathrm{mg} / \mathrm{L}$ para o reator preenchido com carvão ativado e menos de $200 \mathrm{mg} / \mathrm{L}$ para argila expandida) devido a dificuldade obtida em preparar dois frascos de alimentação separadamente. Todavia, ao longo dos dias, tais problemas foram sendo sanados e a concentração de DQO em cada nova suplementação manteve-se mais próxima a $600 \mathrm{mg} / \mathrm{L}$ como na etapa IV (reatores com pérolas de vidro e areia.

\subsubsection{Monitoramento}

Durante as etapas de operação II e V, os reatores foram operados em circuito aberto conforme esquema apresentado na Figura 4.4. A alimentação consistiu somente de substrato sintético contendo, em média, $566 \pm 45 \mathrm{mg} / \mathrm{L}$ de DQO em R1 e R2 e $507 \pm 20$ mg/L de DQO em R3 e R4.

Nesta fase observou-se eficiência média de remoção de matéria orgânica (DQO filtrada) de $88 \pm 9 \%$ para R1, $84 \pm 5 \%$ para R2 , $89 \pm 5 \%$ para R3 e $89 \pm 2 \%$ para R4. Os valores de DQO afluente e efluente bem como a porcentagem de remoção ao longo do tempo estão apresentados nas FigurasFigura 5.11 a Figura 5.14.

Após o período de alimentação com substrato sintético, deram-se início as etapas III e VI de operação dos reatores com presença de LAS na alimentação em concentração média de 16,4 mg/L. Os valores de DQO afluente foram, em média, $558 \pm 52 \mathrm{mg} / \mathrm{L} \mathrm{em}$ $\mathrm{R} 1$ e R2 e $568 \pm 23 \mathrm{mg} / \mathrm{L}$ em R3 e R4.

Em trabalho de degradação anaeróbia de LAS em reator horizontal de leito fixo, foi observado inibição dos microrganismos após a adição de $14 \mathrm{mg} / \mathrm{L}$ de surfactante a alimentação. Houve diminuição na porcentagem de remoção de matéria orgânica de 97\% para 77\% em reator preenchido com carvão vegetal como material suporte. Porém, após 20 dias de operação, a remoção voltou a alcançar valores de 90\% (Oliveira et al., 2009).

No presente trabalho, em reatores de leito fluidificado, os elevados valores obtidos para remoção de DQO filtrada na etapa após adição do surfactante, em todos os reatores $(96 \pm 2 \%$ para $\mathrm{R} 1,91 \pm 6 \%$ para R2 , 97 $\pm 2 \%$ para R3 e 94 $\pm 5 \%$ para R4) mostraram que a presença do LAS não interferiu na degradação da matéria orgânica 
(Figura 5.11 a Figura 5.14). Ao contrário, notou-se aumento na porcentagem de remoção de DQO em todos os reatores.

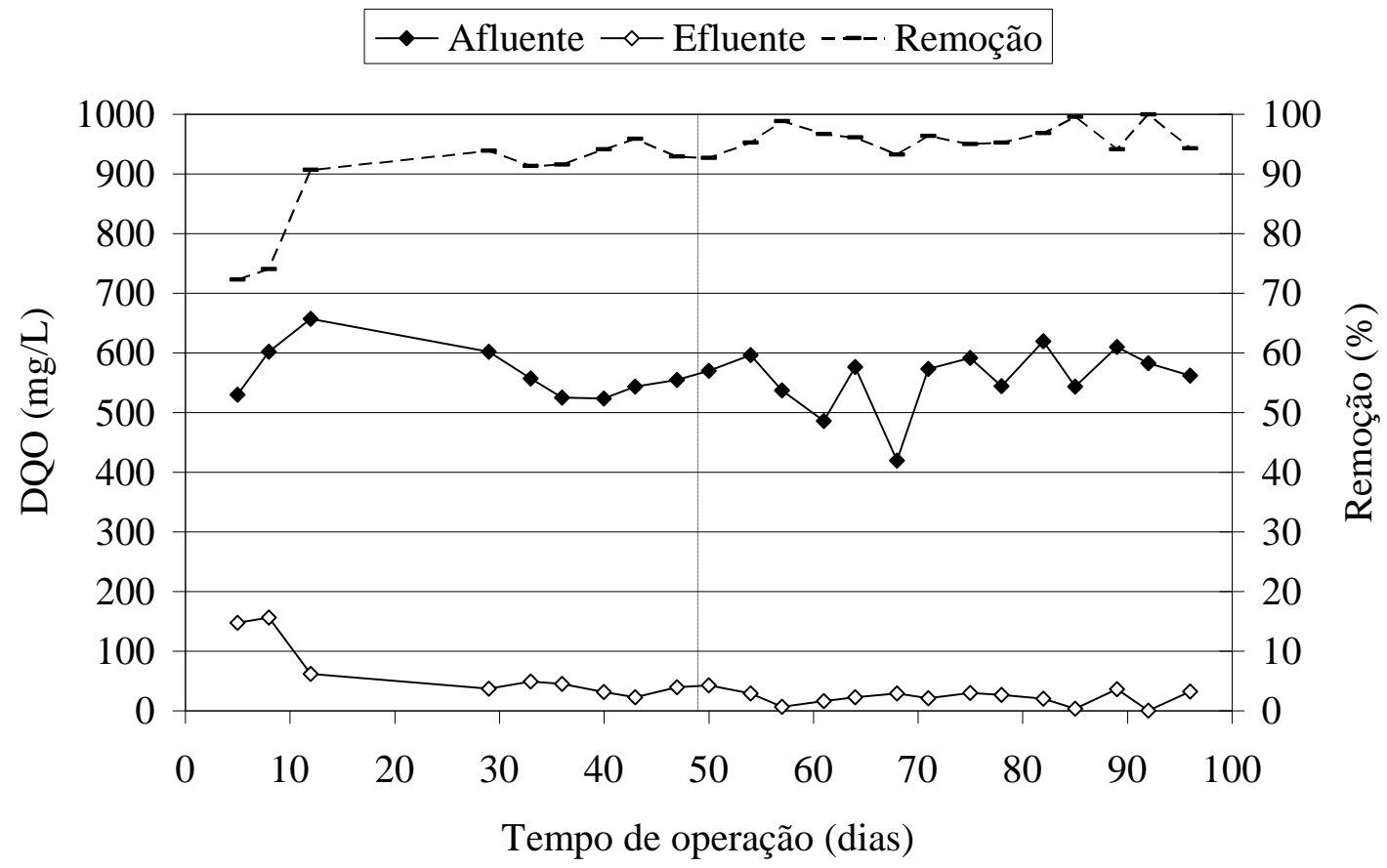

Figura 5.11: Variação temporal da DQO filtrada afluente e efluente e eficiência de remoção em R1 (carvão ativado)

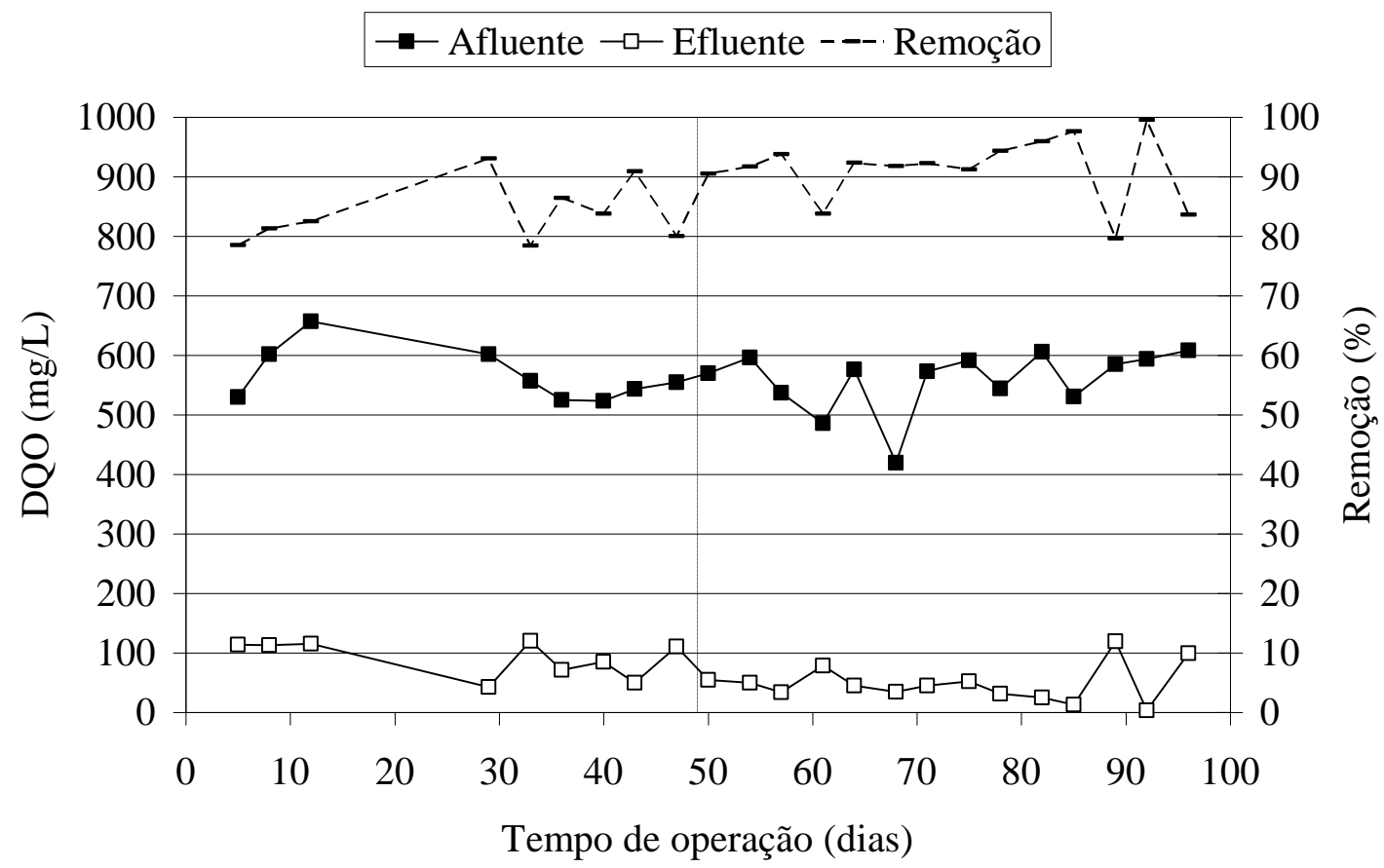

Figura 5.12: Variação temporal da DQO filtrada afluente e efluente e eficiência de remoção em R2 (argila expandida) 


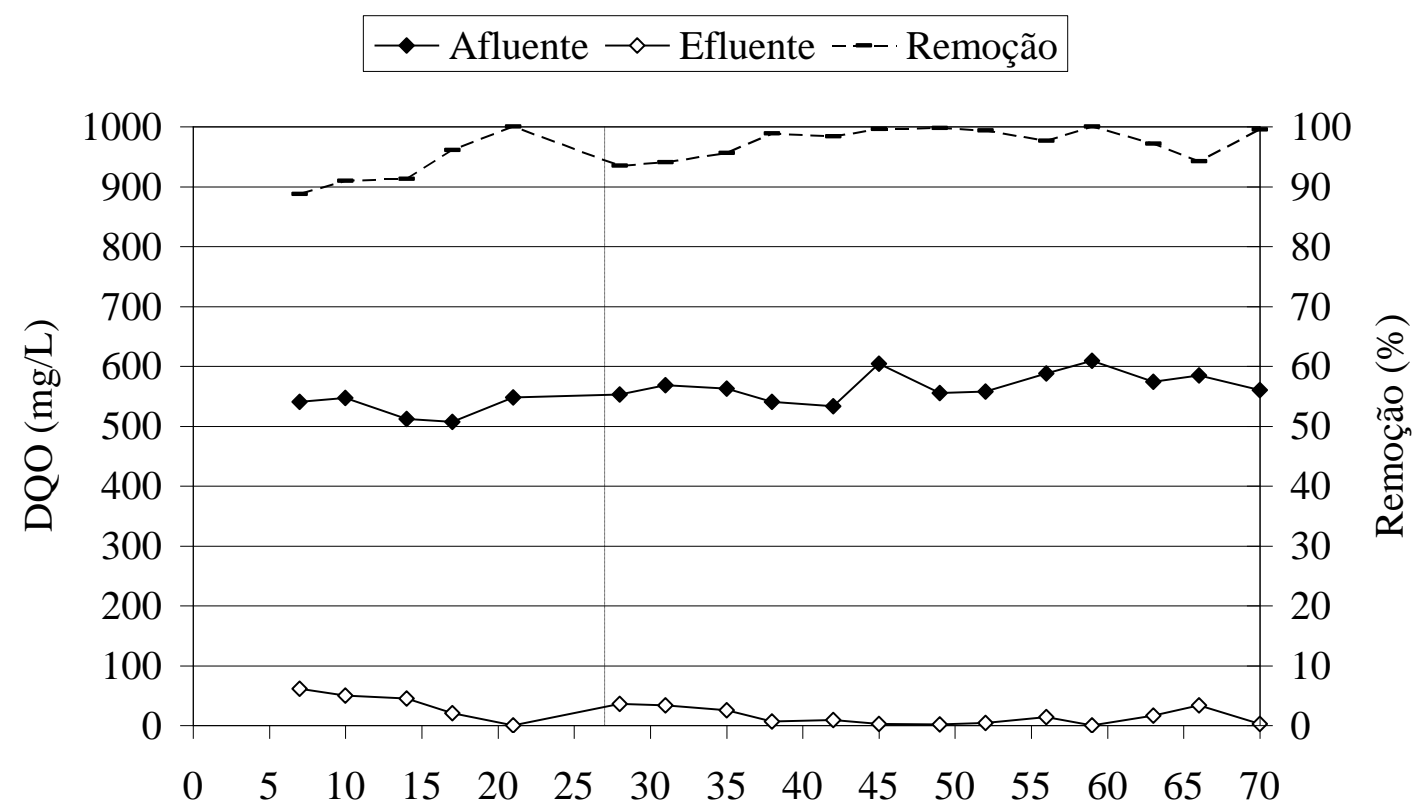

Tempo de operação (dias)

Figura 5.13: Variação temporal da DQO filtrada afluente e efluente e eficiência de remoção em R3 (pérolas de vidro)

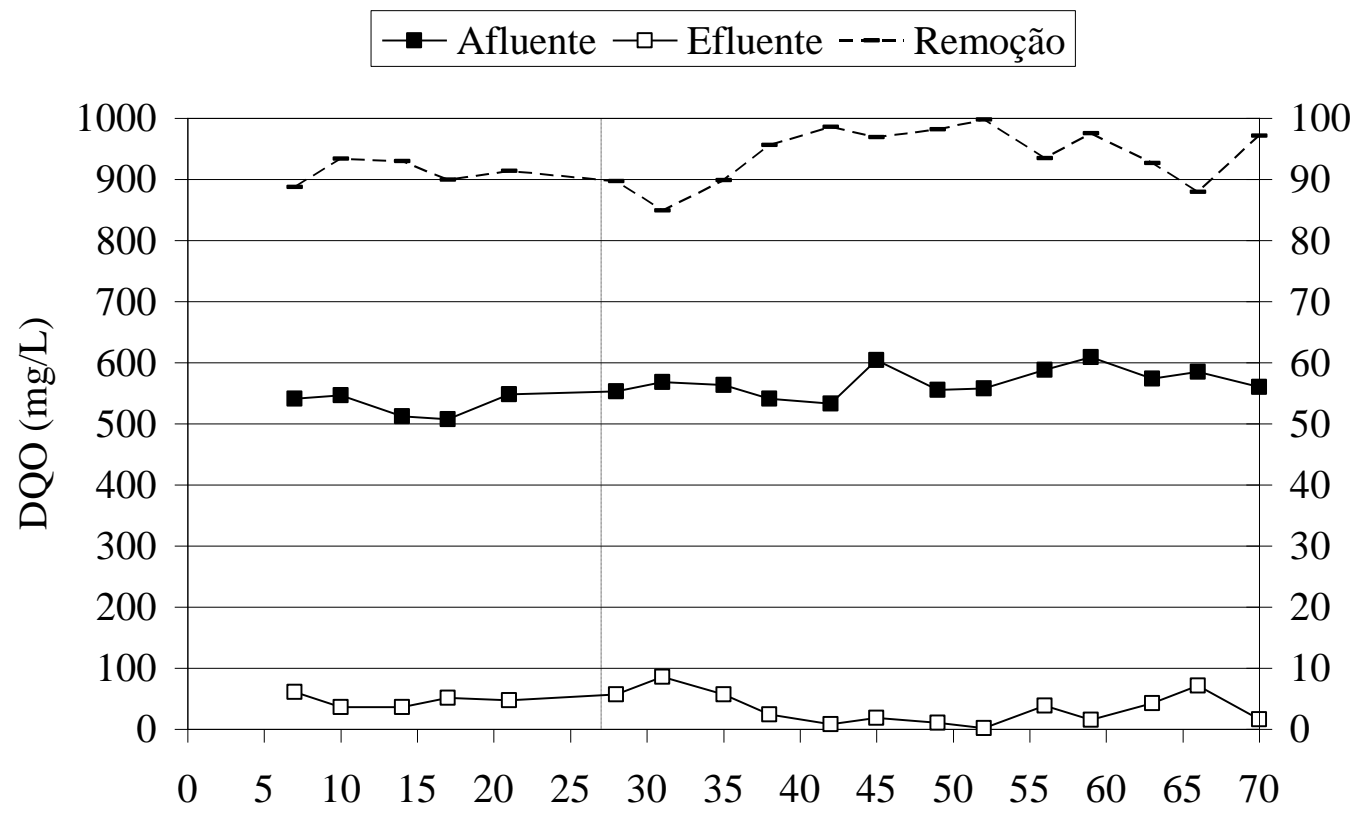

Tempo de operação (dias)

Figura 5.14: Variação temporal da DQO filtrada afluente e efluente e eficiência de remoção em R4 (areia) 
Durante as etapas II e $\mathrm{V}$, os valores de $\mathrm{pH}$ de todos os reatores mantiveram-se próximos ao neutro apresentando valor mínimo de 7,3 no afluente de R1 e R2 e máximo de 8,4 no efluente de R1. Os sistemas apresentaram alcalinidade efluente (em média $155 \pm 14 \mathrm{mgCaCO}_{3} / \mathrm{L}$ em R1, $157 \pm 22 \mathrm{mgCaCO}_{3} / \mathrm{L} \mathrm{em} \mathrm{R2,} 159 \pm 9 \mathrm{mgCaCO}_{3} / \mathrm{L} \mathrm{em} \mathrm{R} 3$ e $185 \pm 44 \mathrm{mgCaCO}_{3} / \mathrm{L}$ em R4), apresentada como alcalinidade a bicarbonato. A concentração de ácidos voláteis totais (AVT) efluente dos reatores esteve entre 10 e 23 mgHAc/L em R1, 9 e 25 mgHAc/L em R2, 10 e 15 mgHAc/L em R3 e entre 12 e $18 \mathrm{mgHAc} / \mathrm{L}$ em R4.

Na presença de LAS (etapas III e VI), os valores de $\mathrm{pH}$ de todos os reatores continuaram próximos ao neutro apresentando valor mínimo de 7,4 no efluente de R2 e máximo de 8,3 no efluente de R3. Os sistemas apresentaram alcalinidade efluente (em média $137 \pm 10 \mathrm{mgCaCO}_{3} / \mathrm{L}$ em R1, $135 \pm 14 \mathrm{mgCaCO}_{3} / \mathrm{L} \mathrm{em} \mathrm{R2,} 154 \pm 17 \mathrm{mgCaCO}_{3} / \mathrm{L}$ em R3 e154 $\left.\pm 14 \mathrm{mgCaCO}_{3} / \mathrm{L} \mathrm{R} 4\right)$, apresentada como alcalinidade a bicarbonato. A concentração de ácidos voláteis totais (AVT) no efluente dos reatores esteve entre 10 e $21 \mathrm{mgHAc} / \mathrm{L}$ em R1, 12 e 20 mgHAc/L em R2, 6 e 15 mgHAc/L em R3 e entre 9 e $15 \mathrm{mgHAc} / \mathrm{L}$ em R4.

Pode-se observar que a presença do LAS não alterou o $\mathrm{pH}$ do sistemas. Quanto a alcalinidade efluente, os valores foram ligeiramente menores quando comparados a ausência do surfactante. Os valores médios de ácidos totais no efluente mantiveram-se constantes. No entanto, em trabalhos semelhantes que estudaram a degradação anaeróbia do mesmo surfactante, porém em reator horizontal de leito fixo (Oliveira, et al., 2009 e Duarte et al. 2008 e 2009) os valores de alcalinidade a bicarbonato estiveram sempre acima de $300 \mathrm{mgCaCO}_{3} / \mathrm{L}$ em todos os estágios de operação para o mesmo substrato sintético e LAS. Ácidos totais e pH e estiveram em torno de $15 \mathrm{mgHAc} / \mathrm{L} \mathrm{e} \mathrm{7,}$ respectivamente, apresentando assim valores semelhantes aos obtidos nos reatores de leito fluidificado.

Nas Figuras Figura 5.15 a Figura 5.26 estão apresentados os resultados de monitoramento de rotina durante toda a operação dos reatores quanto a $\mathrm{pH}$, alcalinidades parcial, total, a bicarbonato e ácidos voláteis totais que foram sumarizados nas Tabelas Tabela 5.7 e Tabela 5.8. 


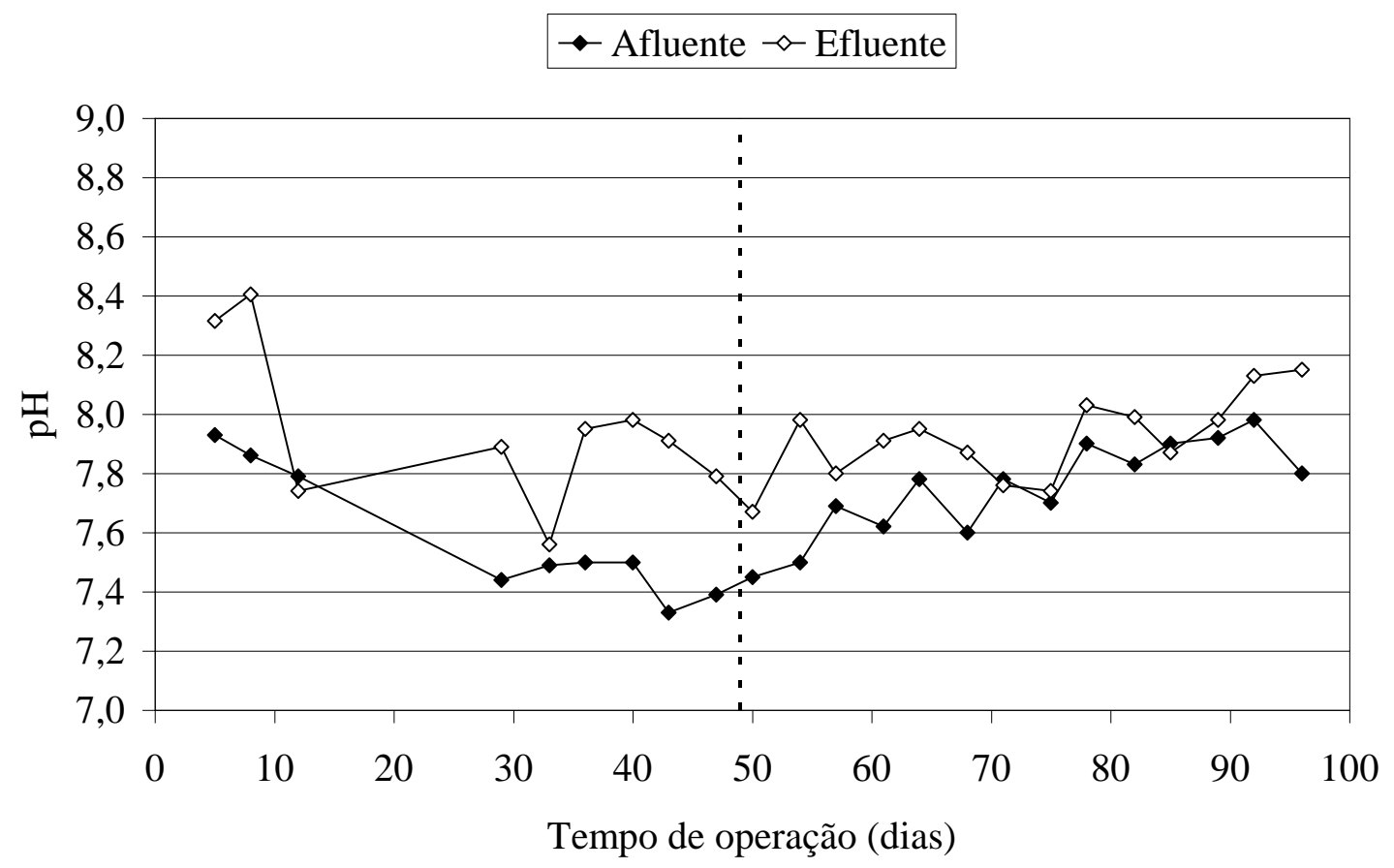

Figura 5.15: Variação temporal do pH afluente e efluente em R1 (carvão ativado)

- Afluente - - Efluente

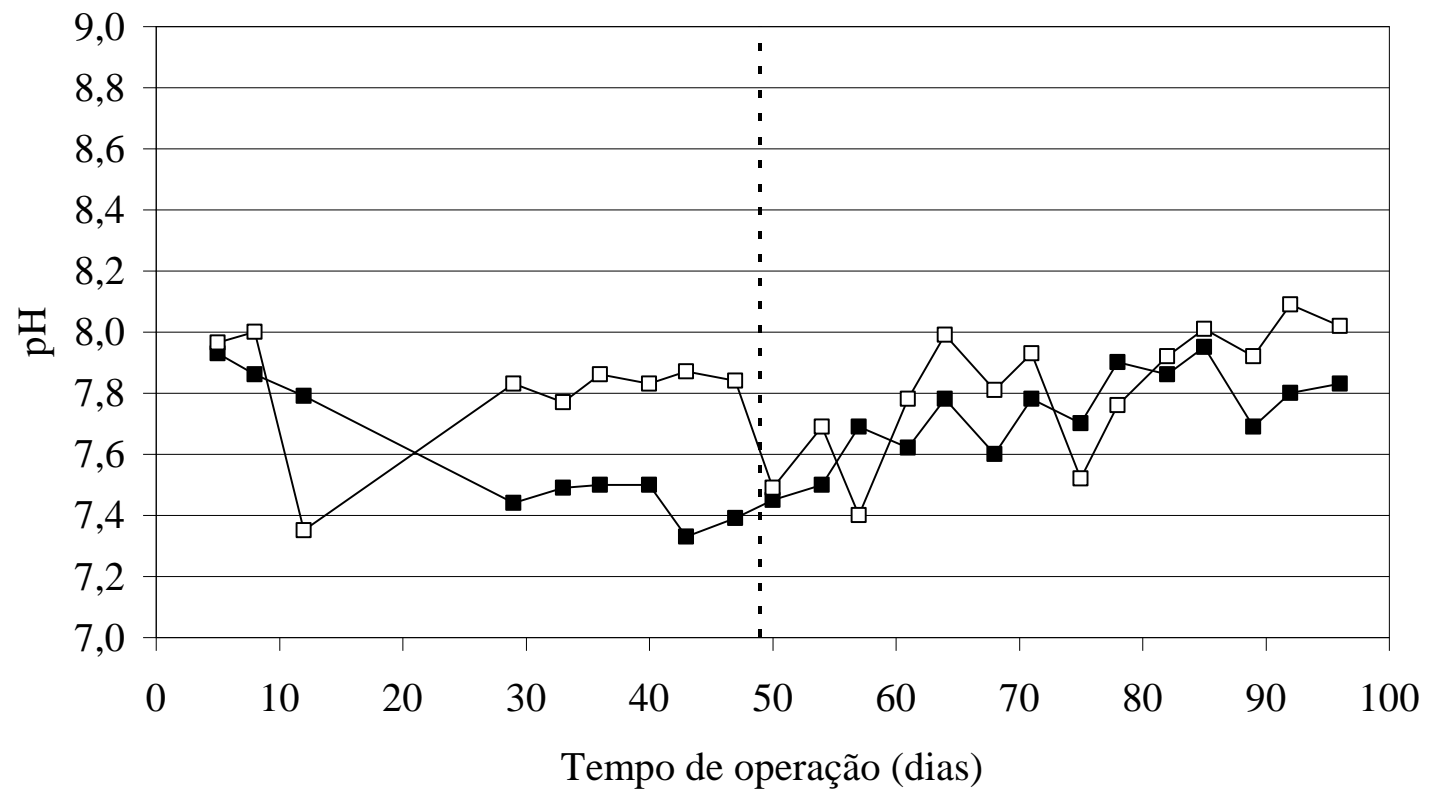

Figura 5.16: Variação temporal do pH afluente e efluente em R2 (argila expandida) 


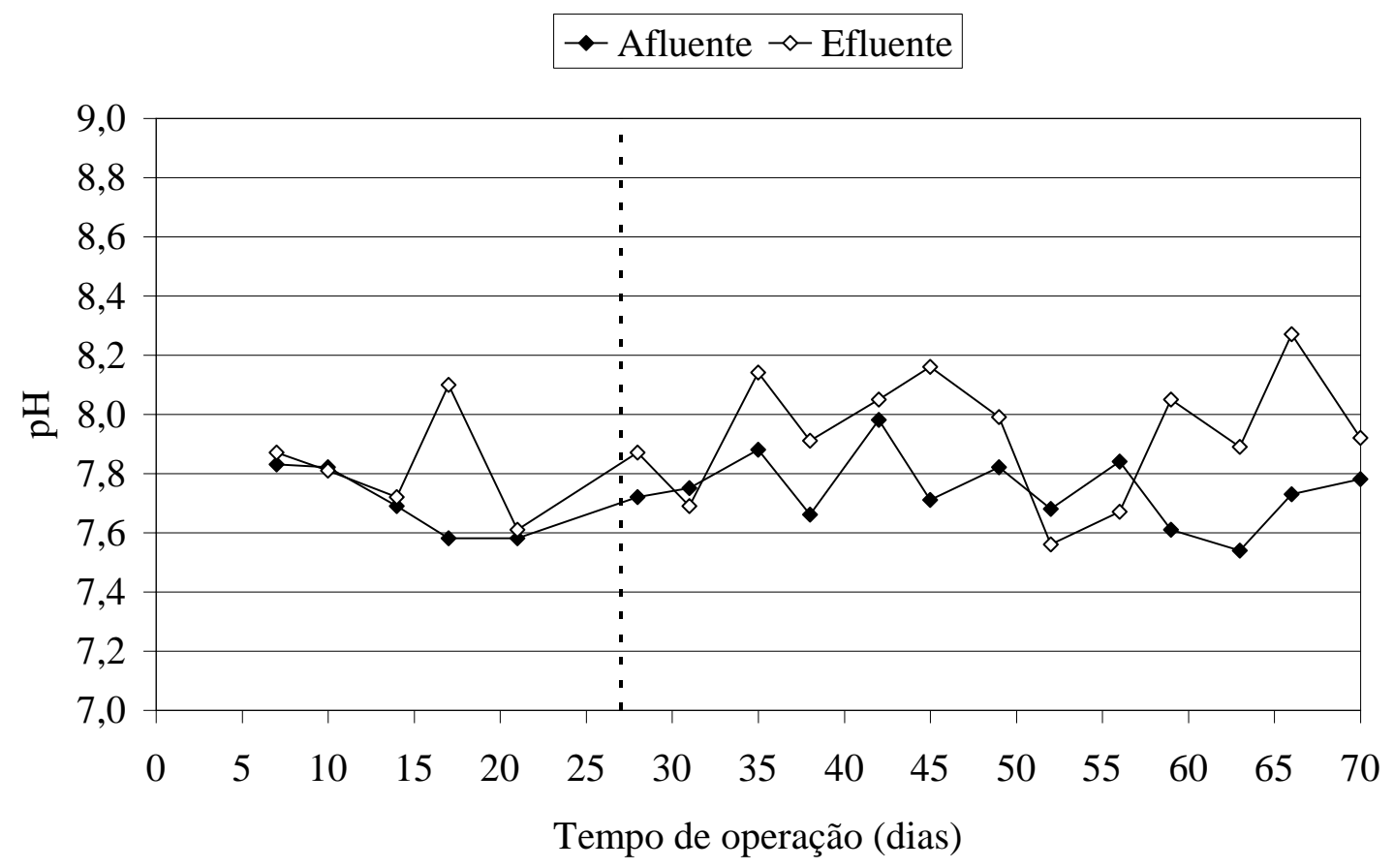

Figura 5.17: Variação temporal do pH afluente e efluente em R3 (pérolas de vidro)

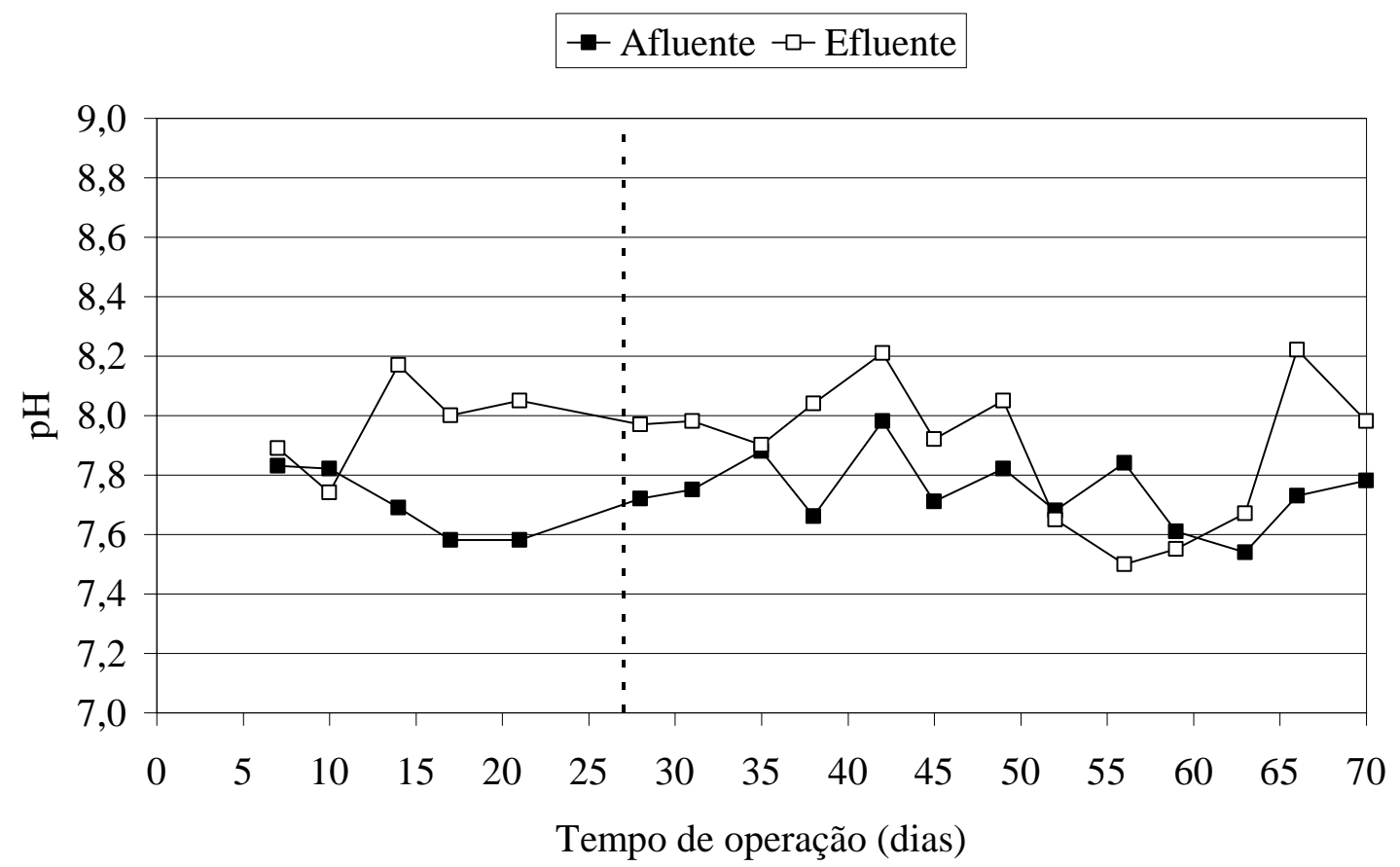

Figura 5.18: Variação temporal do pH afluente e efluente em R4 (areia) 


\section{Afluente parcial $\diamond$ Efluente parcial $₫$ Afluente total $\triangleleft$ Efluente total}

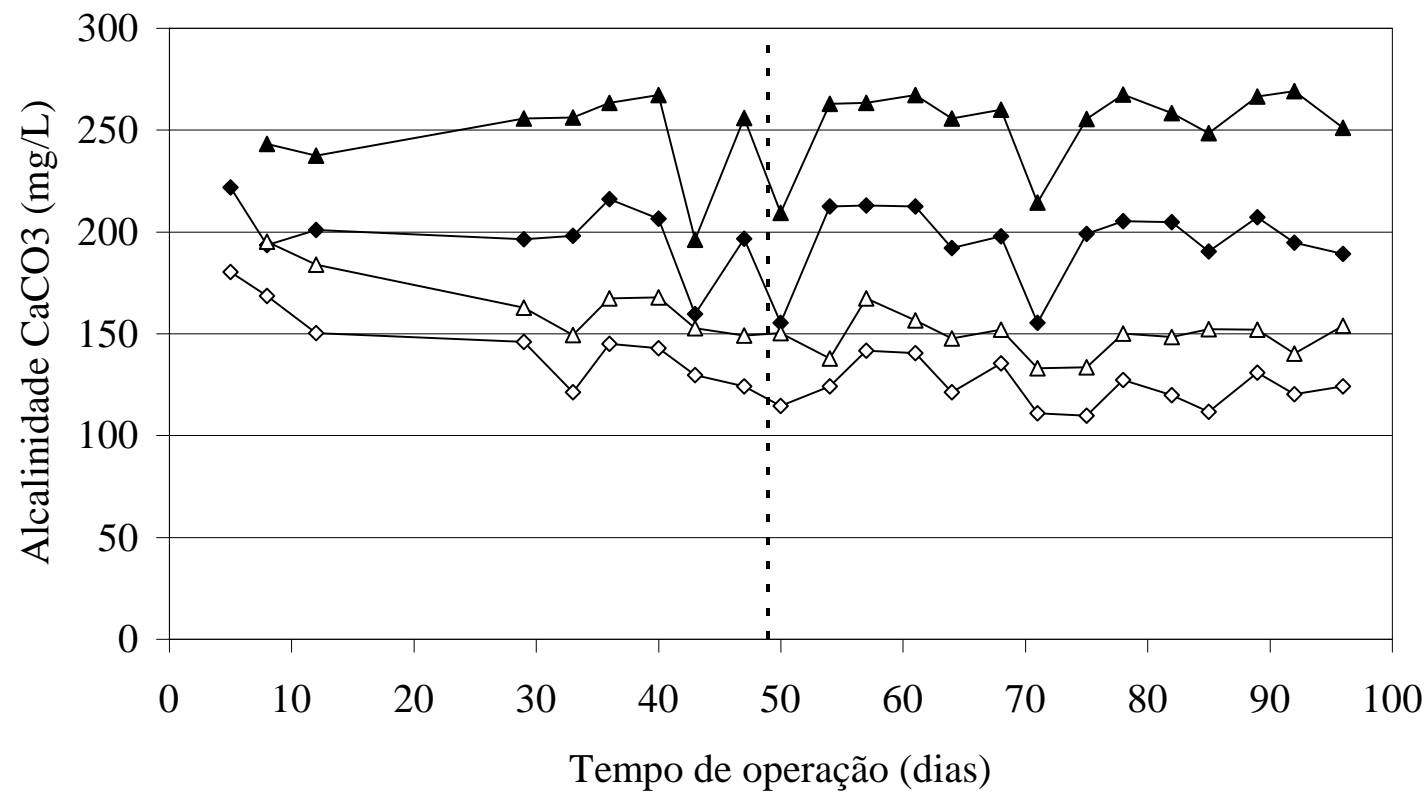

Figura 5.19: Variação temporal da alcalinidade parcial e total afluente e efluente em R1 (carvão ativado)

\section{- Afluente parcial $\rightarrow$ - Efluente parcial $\rightarrow$ Afluente total $\rightarrow-$ Efluente total}

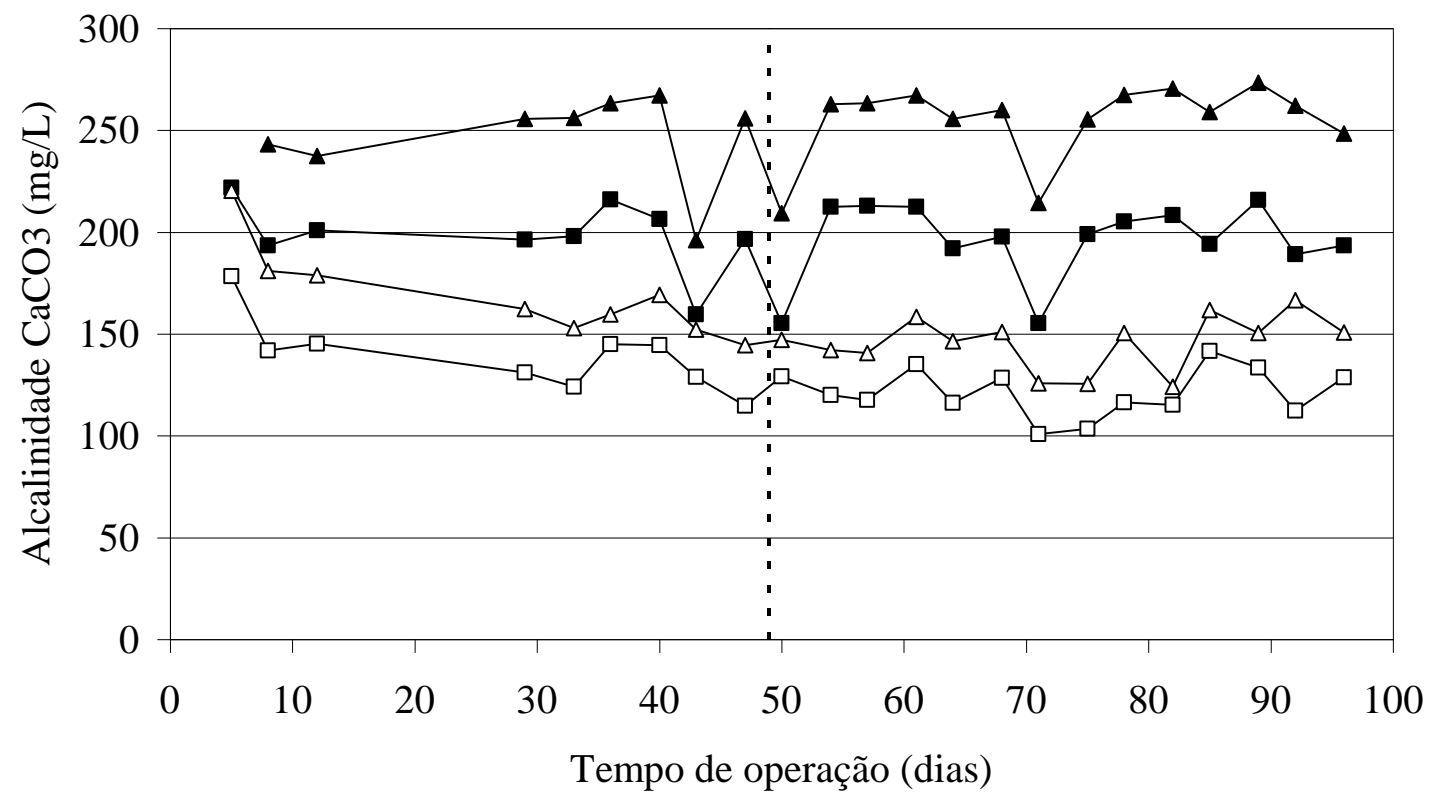

Figura 5.20: Variação temporal da alcalinidade parcial e total afluente e efluente em R2 (argila expandida) 


\section{Afluente parcial $\diamond$ Efluente parcial $₫$ Afluente total $\triangleleft-$ Efluente total}

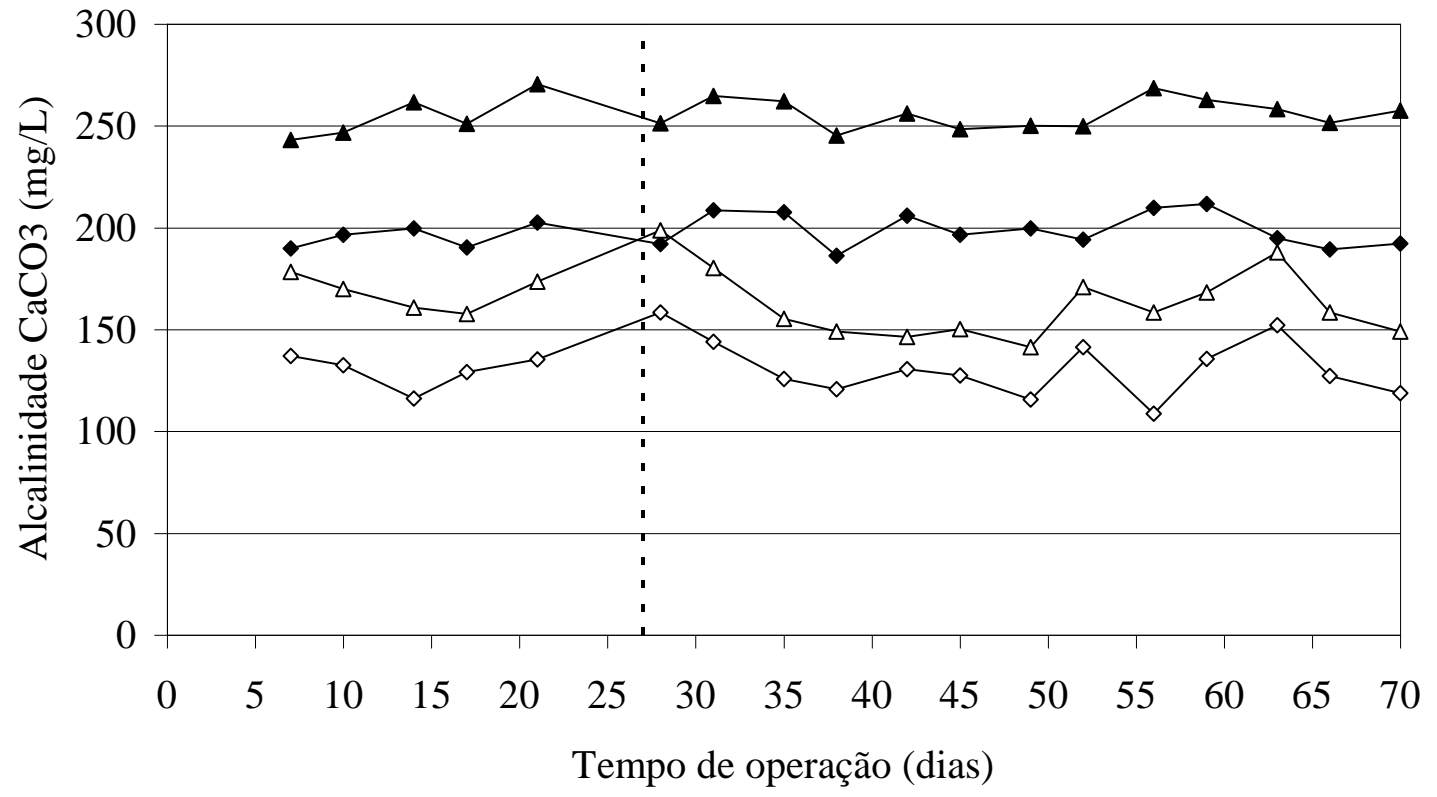

Figura 5.21: Variação temporal da alcalinidade parcial e total afluente e efluente em R3 (pérolas de vidro)

\section{Afluente parcial $\rightarrow-$ Efluente parcial $₫$ Afluente total $\triangle-$ Efluente total}

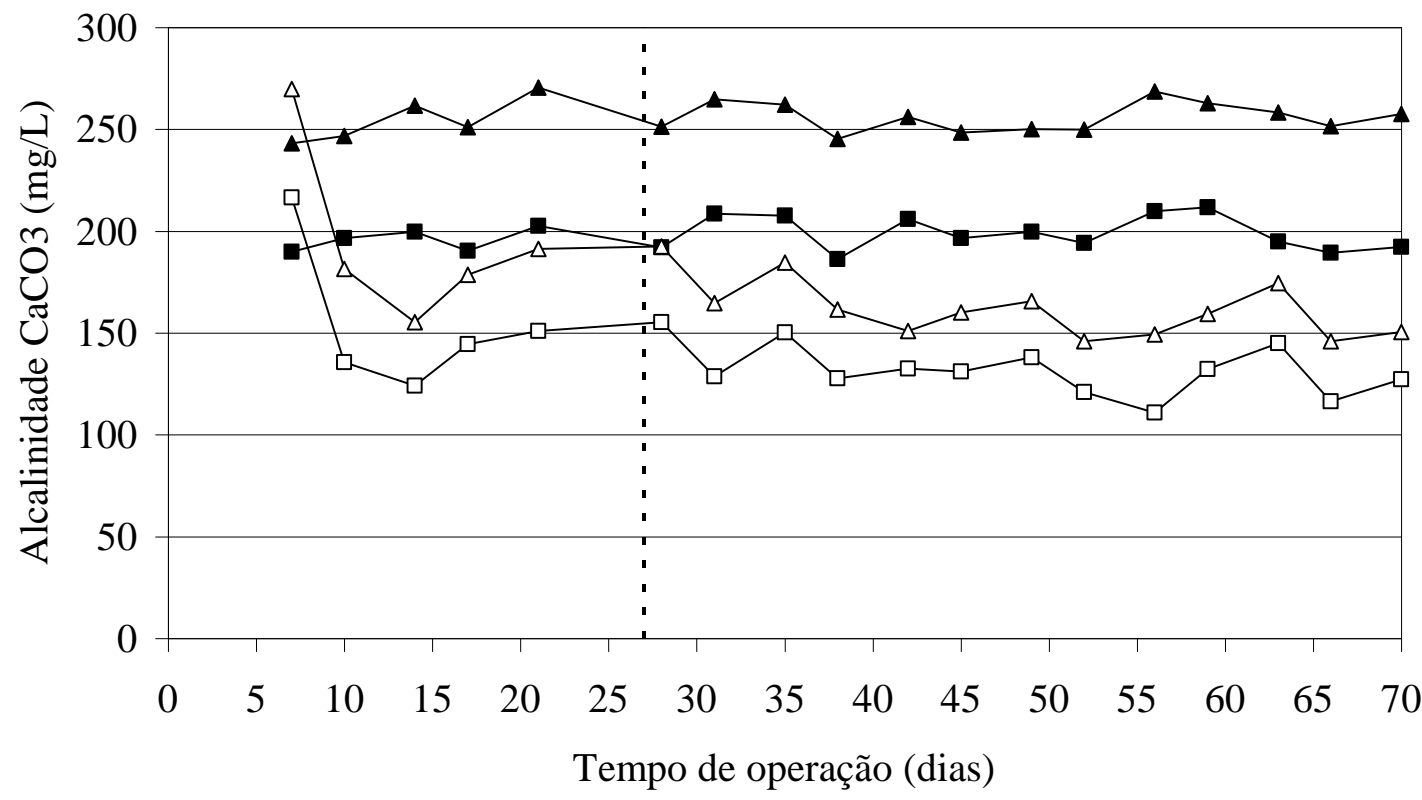

Figura 5.22: Variação temporal da alcalinidade parcial e total afluente e efluente em R4 (areia) 


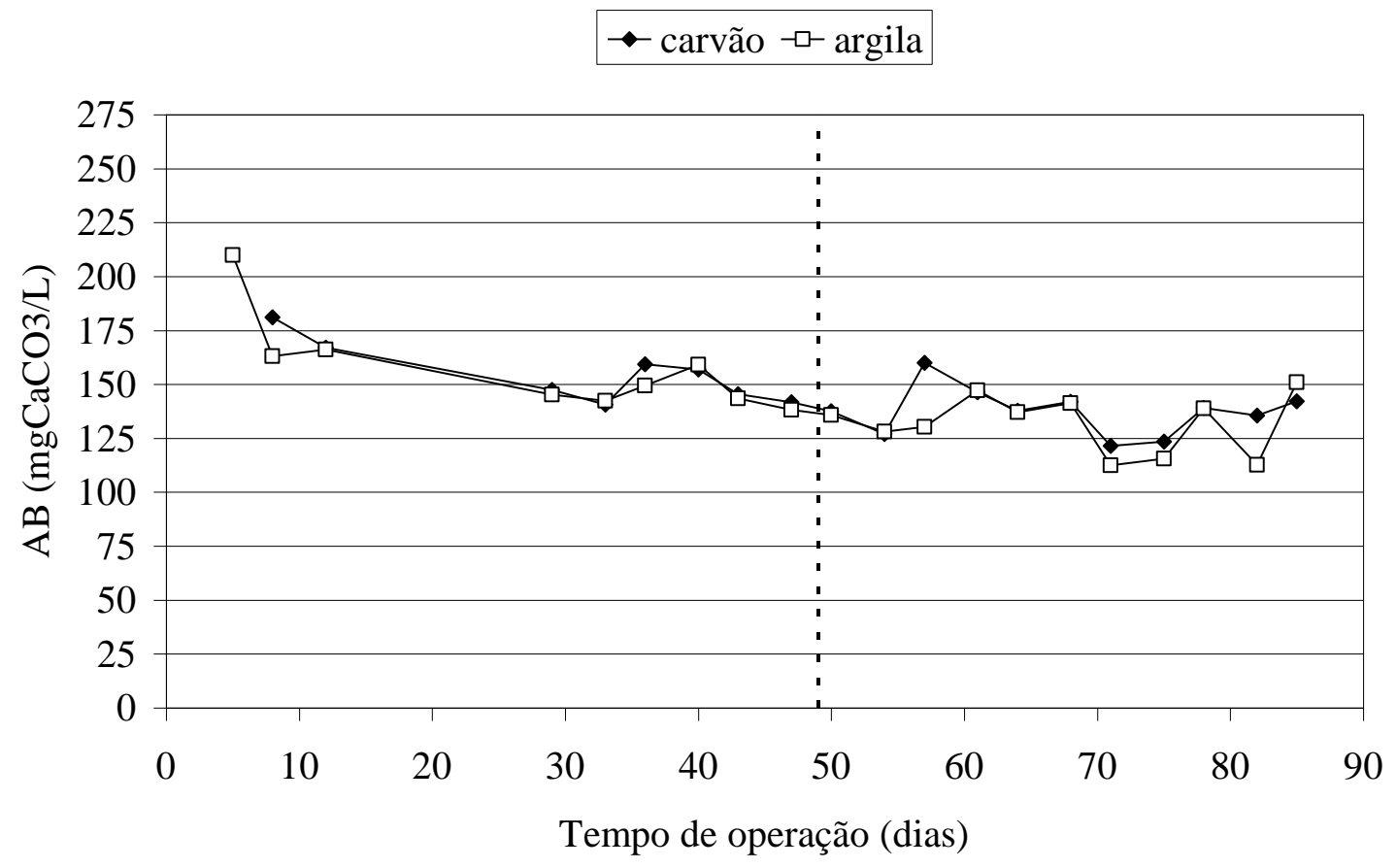

Figura 5.23: Variação temporal da alcalinidade a bicarbonato efluente em R1 (carvão ativado) e R2 (argila expandida)

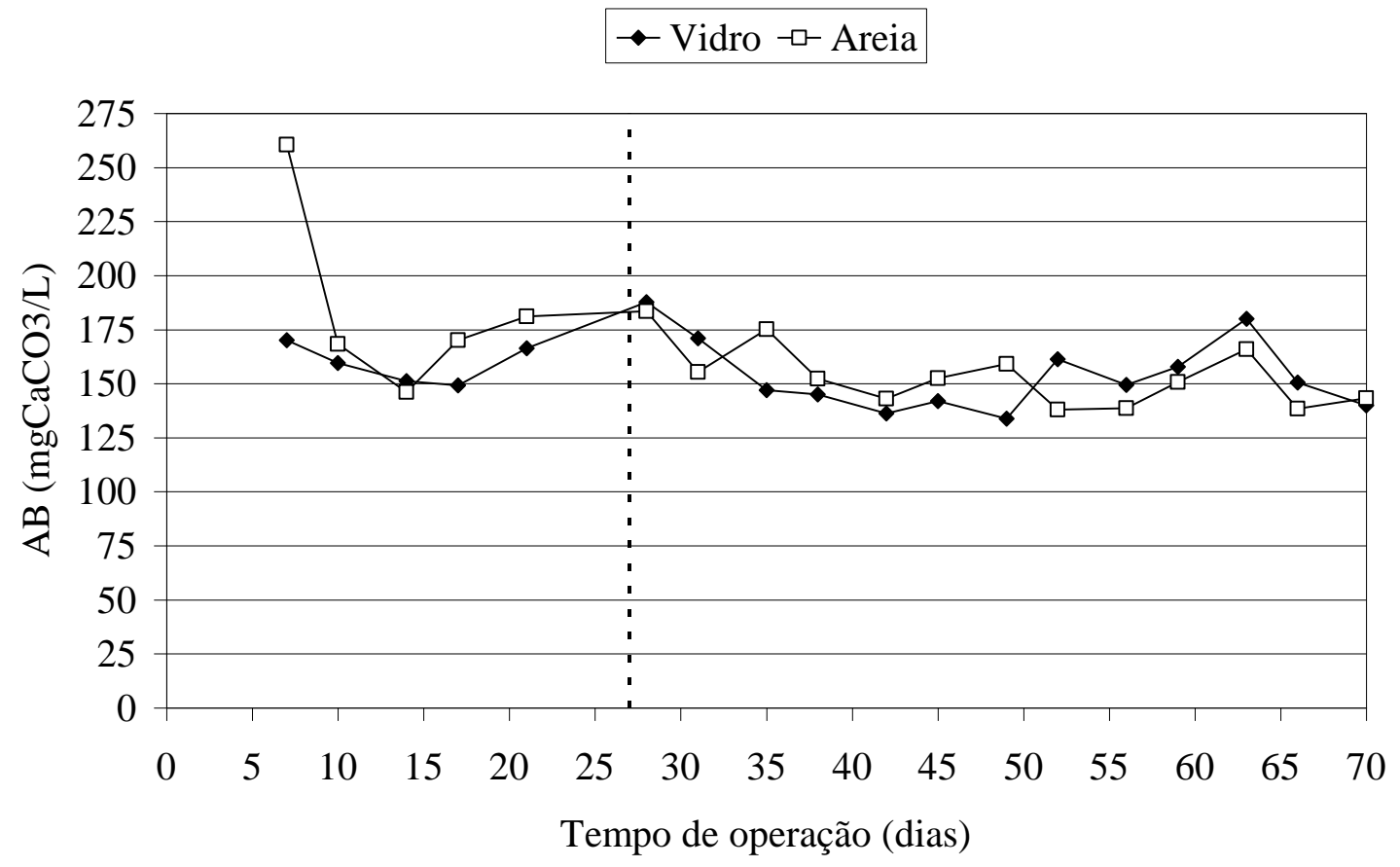

Figura 5.24: Variação temporal da alcalinidade a bicarbonato efluente em R3 (pérolas de vidro) e R4 (areia) 


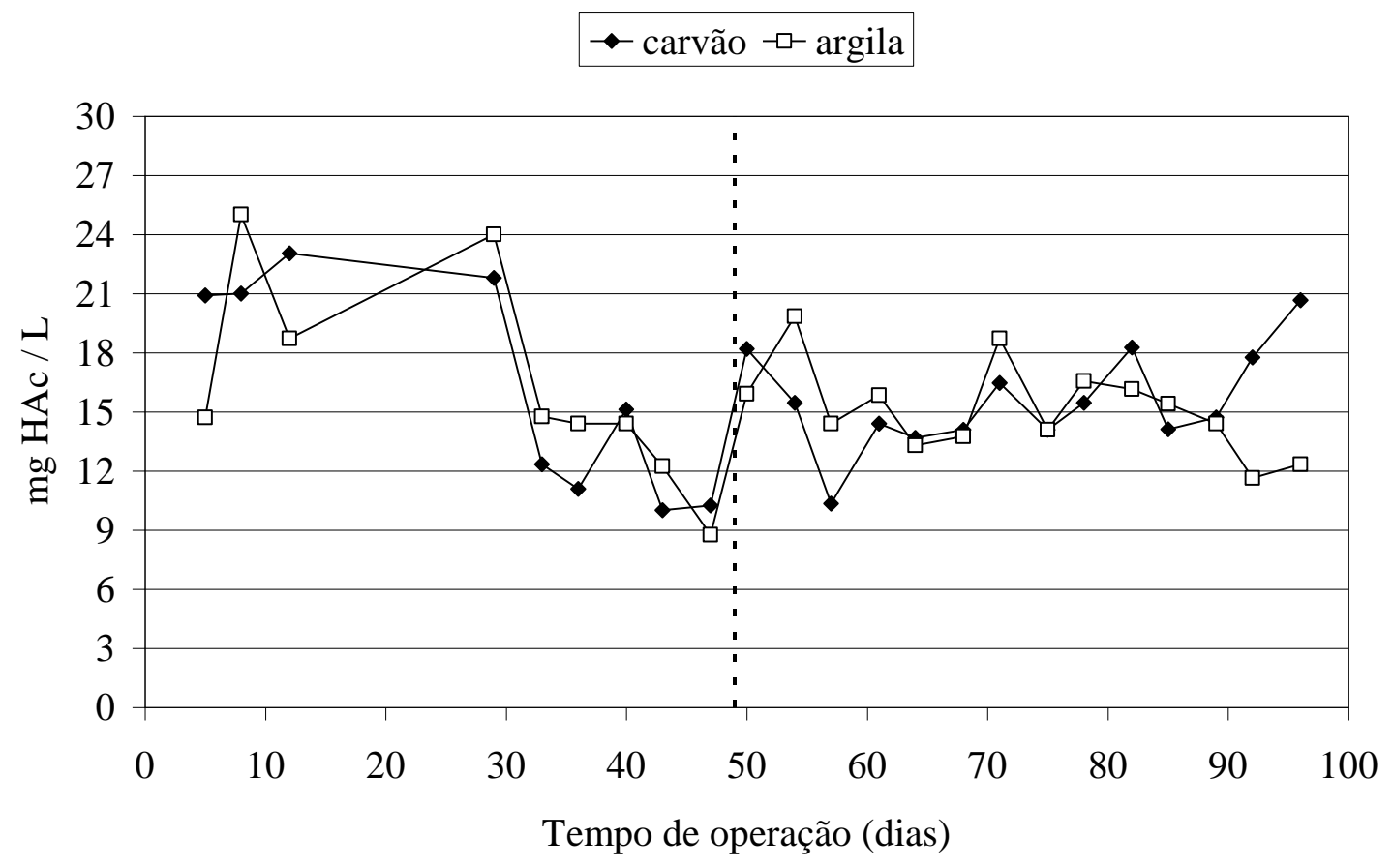

Figura 5.25: Variação temporal de ácidos voláteis totais efluente em R1 (carvão ativado) e R2 (argila expandida)

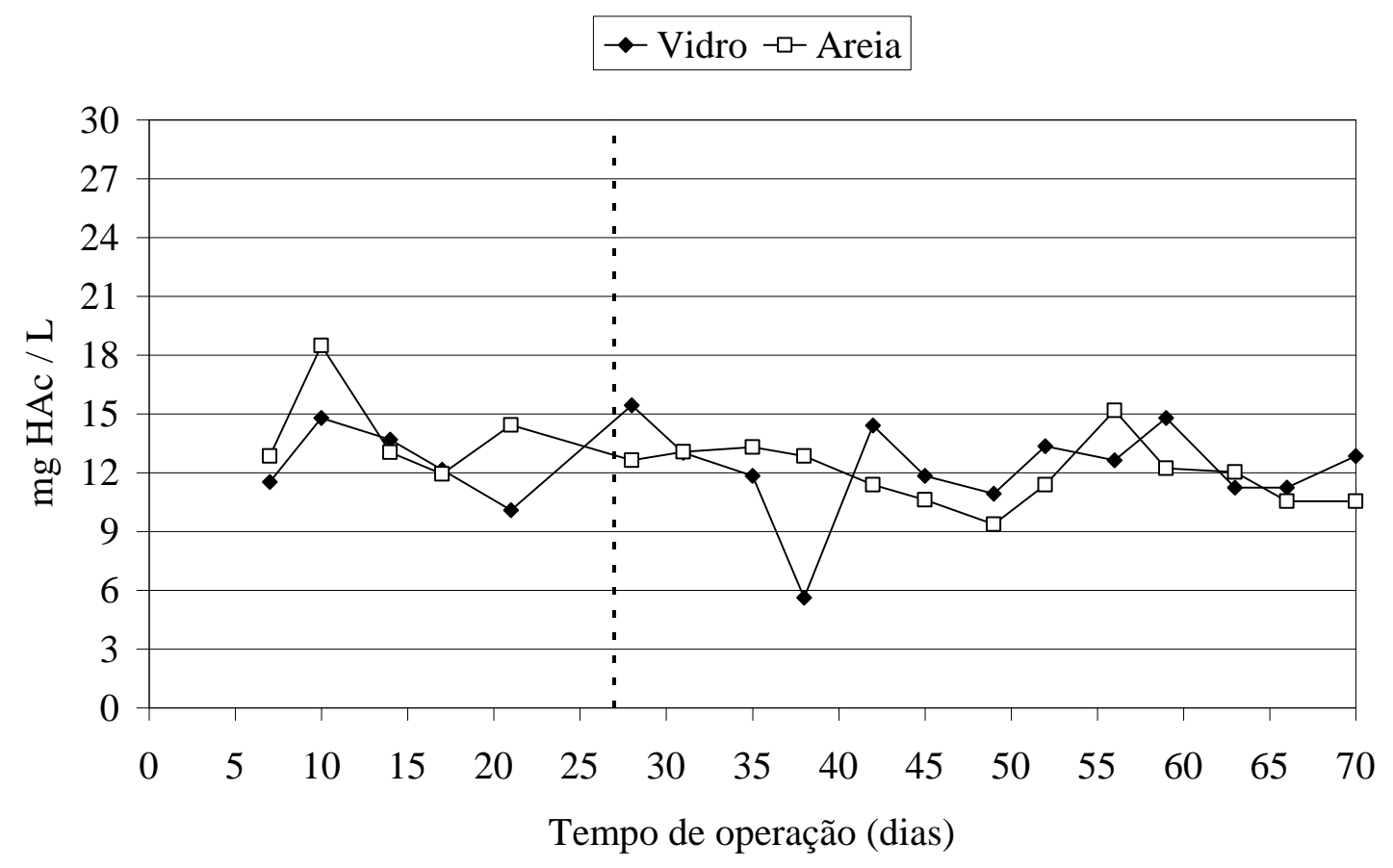

Figura 5.26: Variação temporal de ácidos voláteis totais efluente em R3 (pérolas de vidro) e R4 (areia) 
Tabela 5.7: Valores dos parâmetros físico-químicos do afluente e efluente dos reatores de leito fluidificado durante etapas II e V

\begin{tabular}{|c|c|c|c|c|c|c|c|}
\hline Reator & Amostra & $\begin{array}{l}\text { DQO }_{\mathrm{f}} \\
(\mathrm{mg} / \mathrm{L})\end{array}$ & $\mathbf{p H}$ & $\mathbf{A P}$ & $\left(\mathrm{mgCaCO}_{3} / \mathrm{L}\right)$ & ${ }^{A B}$ & $\begin{array}{c}\text { AVT } \\
(\mathrm{mgHAc} / \mathrm{L})\end{array}$ \\
\hline \multirow{3}{*}{$\mathrm{R} 1$} & Afluente & $565,7 \pm 45,2$ & $7,6 \pm 0,2$ & $199 \pm 18$ & $247 \pm 23$ & & \\
\hline & Efluente & $65,3 \pm 50,2$ & $7,9 \pm 0,3$ & $145 \pm 20$ & $166 \pm 17$ & $155 \pm 14$ & $16 \pm 5$ \\
\hline & Efic. $(\%)$ & $88 \pm 9$ & & & & & \\
\hline \multirow{3}{*}{$\mathrm{R} 2$} & Afluente & $565,7 \pm 45,2$ & $7,6 \pm 0,2$ & $199 \pm 18$ & $247 \pm 23$ & & \\
\hline & Efluente & $91,1 \pm 30,3$ & $7,8 \pm 0,2$ & $139 \pm 18$ & $169 \pm 23$ & $157 \pm 22$ & $16 \pm 5$ \\
\hline & Efic. $(\%)$ & $84 \pm 5$ & & & & & \\
\hline \multirow{3}{*}{ R3 } & Afluente & $530,9 \pm 19,7$ & $7,7 \pm 0,1$ & $196 \pm 6$ & $255 \pm 11$ & & \\
\hline & Efluente & $35,1 \pm 24,7$ & $8,0 \pm 0,2$ & $154 \pm 36$ & $195 \pm 44$ & $159 \pm 9$ & $12 \pm 2$ \\
\hline & Efic. $(\%)$ & $93 \pm 5$ & & & & & \\
\hline \multirow{3}{*}{ R4 } & Afluente & $530,9 \pm 19,7$ & $7,7 \pm 0,1$ & $196 \pm 6$ & $255 \pm 11$ & & \\
\hline & Efluente & $46,3 \pm 10,5$ & $7,8 \pm 0,2$ & $130 \pm 8$ & $168 \pm 9$ & $185 \pm 44$ & $14 \pm 3$ \\
\hline & Efic. $(\%)$ & $91 \pm 2$ & & & & & \\
\hline
\end{tabular}

$(\mathrm{AP}=$ Alcalinidade Parcial; AT $=$ Alcalinidade Total; $\mathrm{AB}=$ Alcalinidade a Bicarbonato; AVT $=$ Ácidos Voláteis Totais)

Tabela 5.8: Valores dos parâmetros físico-químicos do afluente e efluente dos reatores de leito fluidificado durante etapas III e VI

\begin{tabular}{|c|c|c|c|c|c|c|c|}
\hline Reator & Amostra & $\begin{array}{l}\text { DQO }_{f} \\
(\mathrm{mg} / \mathrm{L})\end{array}$ & $\mathbf{p H}$ & \multicolumn{2}{|c|}{$\left(\mathrm{mgCaCO}_{3} / \mathrm{L}\right)$} & ${ }_{\text {L) }}{ }^{A B}$ & $\begin{array}{c}\text { AVT } \\
(\mathrm{mgHAc} / \mathrm{L})\end{array}$ \\
\hline \multirow{3}{*}{$\mathrm{R} 1$} & Afluente & $557,6 \pm 52,2$ & $7,7 \pm 0,2$ & $195 \pm 19$ & $253 \pm 19$ & & \\
\hline & Efluente & $22,3 \pm 12,3$ & $7,9 \pm 0,1$ & $124 \pm 10$ & $148 \pm 9$ & $137 \pm 10$ & $16 \pm 3$ \\
\hline & Efic. (\%) & $96 \pm 2$ & & & & & \\
\hline \multirow{3}{*}{$\mathrm{R} 2$} & Afluente & $558,1 \pm 52,4$ & $7,7 \pm 0,1$ & $196 \pm 19$ & $255 \pm 19$ & & \\
\hline & Efluente & $48,7 \pm 31,9$ & $7,8 \pm 0,2$ & $121 \pm 12$ & $146 \pm 13$ & $135 \pm 14$ & $15 \pm 2$ \\
\hline & Efic. $(\%)$ & $91 \pm 6$ & & & & & \\
\hline \multirow{3}{*}{ R3 } & Afluente & $568,4 \pm 22,7$ & $7,7 \pm 0,1$ & $199 \pm 9$ & $256 \pm 7$ & & \\
\hline & Efluente & $14,2 \pm 13,5$ & $7,9 \pm 0,2$ & $131 \pm 15$ & $163 \pm 17$ & $154 \pm 17$ & $12 \pm 2$ \\
\hline & Efic. $(\%)$ & $97 \pm 2$ & & & & & \\
\hline \multirow{3}{*}{$\mathrm{R} 4$} & Afluente & $568,4 \pm 22,7$ & $77 \pm 0,1$ & $199 \pm 9$ & $256 \pm 7$ & & \\
\hline & Efluente & $34,2 \pm 26,7$ & $7,9 \pm 0,2$ & $132 \pm 13$ & $162 \pm 15$ & $154 \pm 14$ & $12 \pm 2$ \\
\hline & Efic. (\%) & $94 \pm 5$ & & & & & \\
\hline
\end{tabular}

$(\mathrm{AP}=$ Alcalinidade Parcial; $\mathrm{AT}=$ Alcalinidade Total $; \mathrm{AB}=$ Alcalinidade a Bicarbonato; $\mathrm{AVT}=$ Ácidos Voláteis Totais)

Além dos parâmetros mencionados até o momento, após adição do surfactante à alimentação, também foram monitorados a concentração de LAS, sulfato e sulfeto afluente e efluente de todos os reatores. Esperava-se assim observar se a lise da 
molécula do LAS aumentaria as concentrações de sulfato e sulfeto no efluente dos reatores devido à presença do enxofre $(\mathrm{S})$ do anel aromático da molécula do surfactante.

As Figuras Figura 5.27 a Figura 5.30 apresentam os valores de LAS afluente e efluente, bem como sua porcentagem de remoção ao longo do tempo nos quatro reatores.

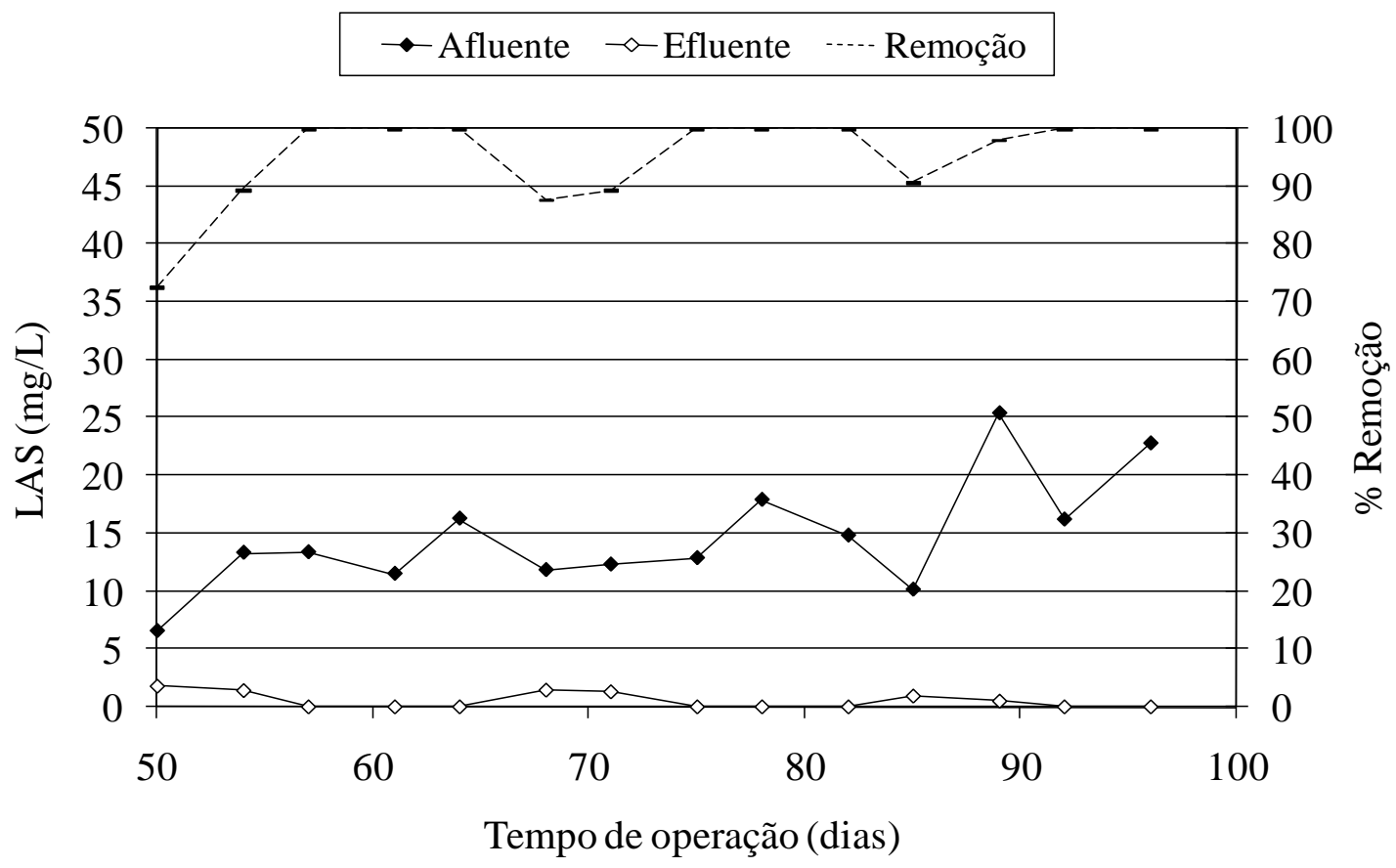

Figura 5.27: Variação temporal da concentração de LAS afluente e efluente em R1 (carvão ativado) 


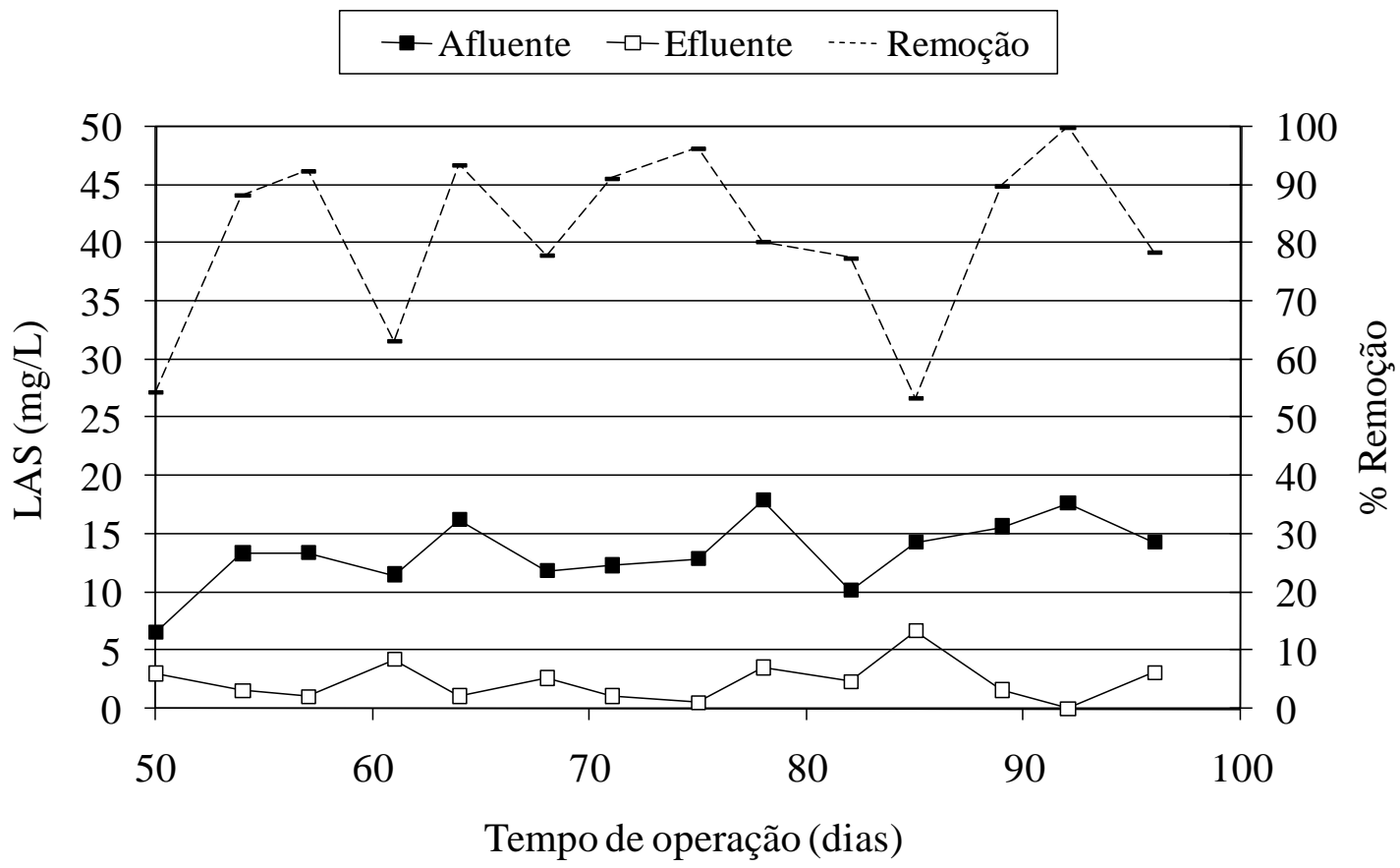

Figura 5.28: Variação temporal da concentração de LAS afluente e efluente em R2 (argila expandida)

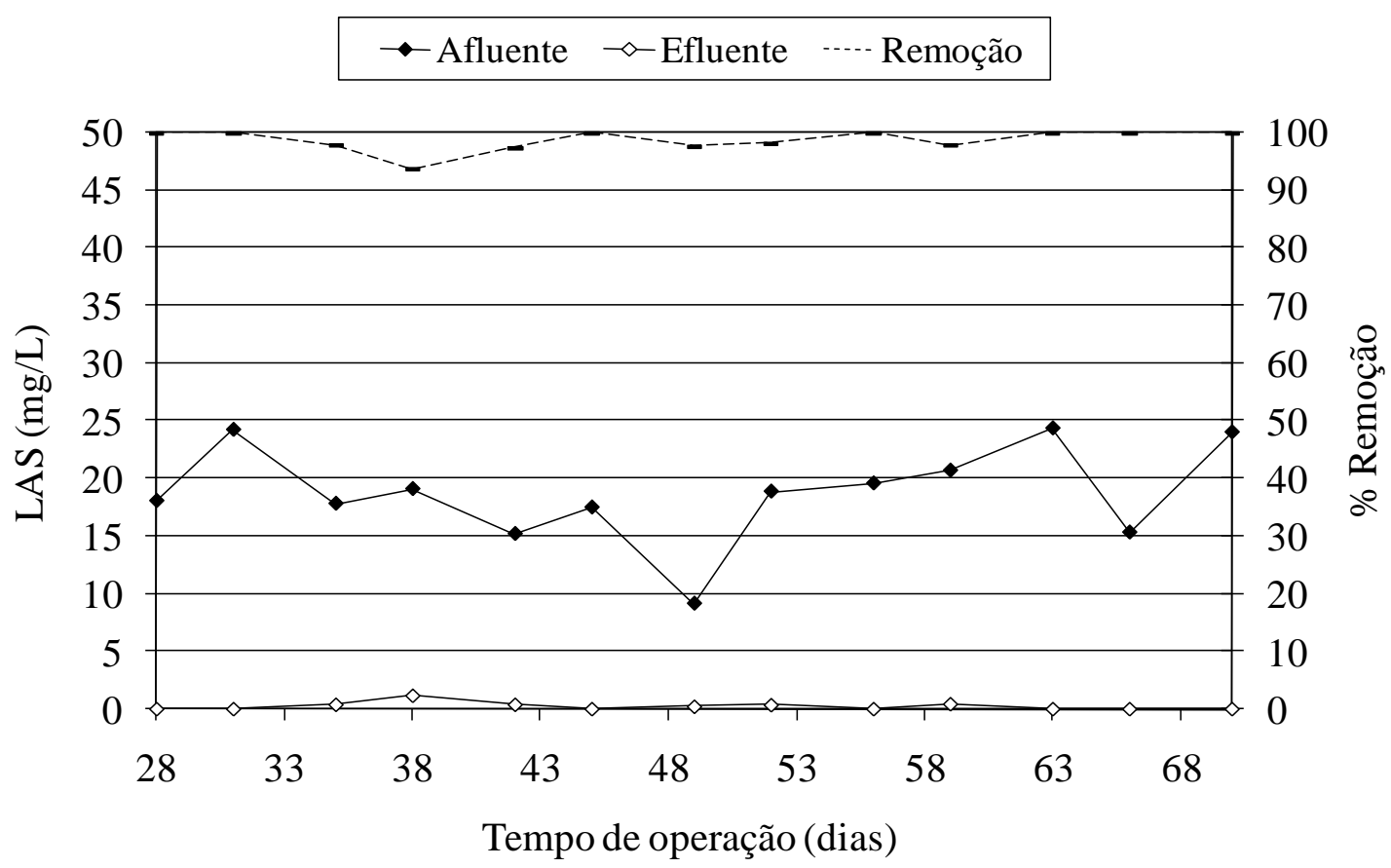

Figura 5.29: Variação temporal da concentração de LAS afluente e efluente em R3 (pérolas de vidro) 


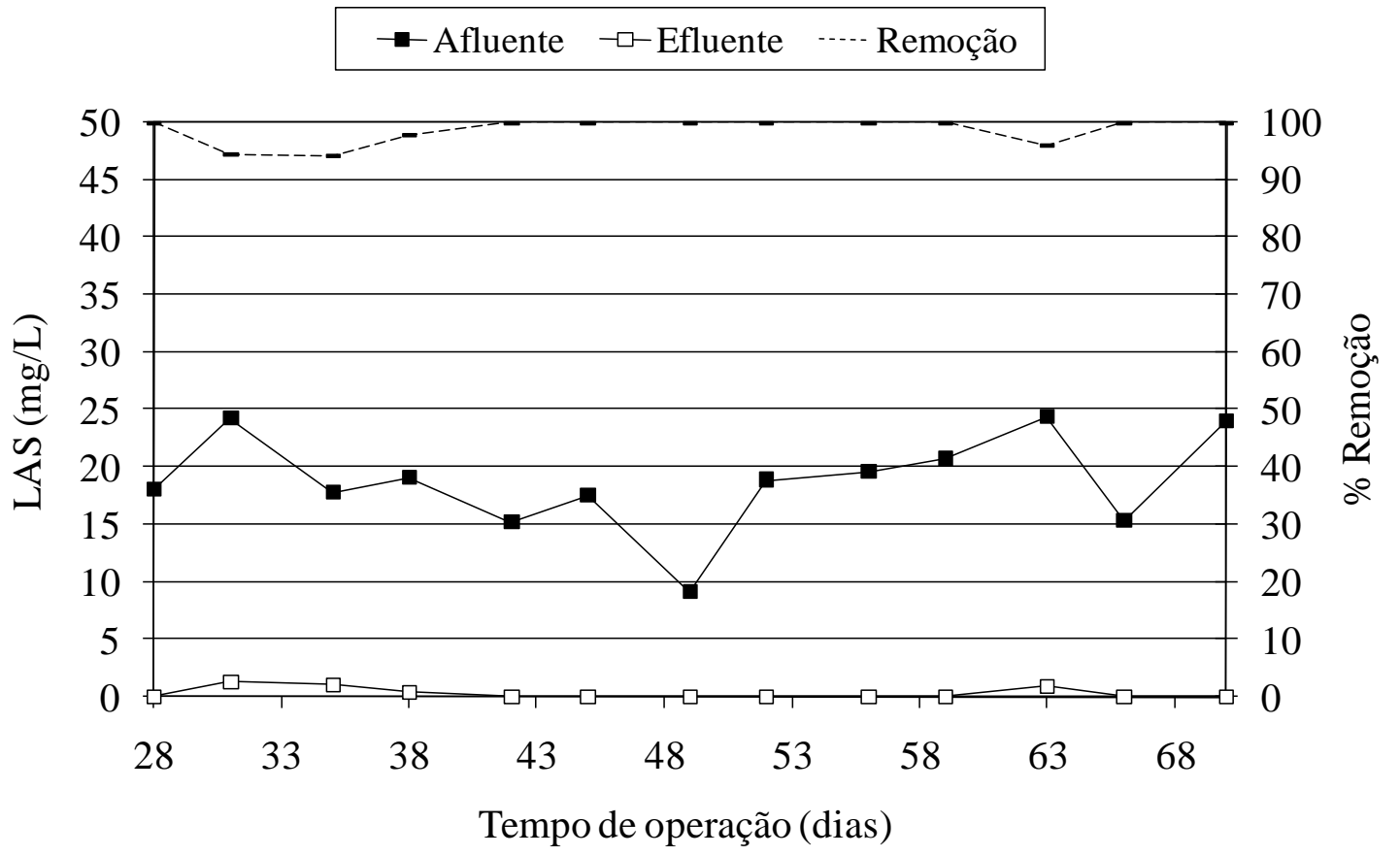

Figura 5.30: Variação temporal da concentração de LAS afluente e efluente em R4 (areia)

$\mathrm{O}$ reator preenchido com carvão ativado (média afluente de $14,7 \pm 4,9 \mathrm{mg} / \mathrm{L}$ de

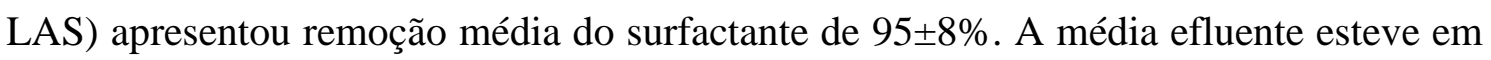
0,5 mg/L porém, por vários dias, a remoção atingiu valores abaixo do limite de detecção da curva $(0,49 \mathrm{mg} / \mathrm{L})$. Tais valores (efluente e remoção) foram melhores que os obtidos para o reator de leito fluidificado preenchido com argila expandida (R2). Nesse último caso, a média de remoção foi $81 \pm 15 \%$ para concentração afluente de $13,4 \pm 3 \mathrm{mg} / \mathrm{L}$ de LAS. A concentração afluente também atingiu valores abaixo do limite de detecção da curva porém a média foi $2,3 \pm 1,8 \mathrm{mg} / \mathrm{L}$, ou seja, maior que em R1.

Já os reatores preenchidos com pérolas de vidro (R3) e areia (R4) apresentaram melhor desempenho que os anteriores, uma vez que removeram em média, 99 $2 \%$ do LAS afluente $(18,8 \pm 4,2 \mathrm{mg} / \mathrm{L})$. Durante todo o período (70 dias de operação), a concentração de LAS efluente esteve próxima ao zero (média de 0,3 e 0,2 mg/L em R3 e R4, respectivamente).

Dentre todos os suportes testados nos reatores de leito fluidificado, pérolas de vidro e areia foram os que apresentaram melhor desempenho removendo praticamente todo o LAS adicionado à alimentação.

Conforme mencionado anteriormente, carvão ativado e argila expandida sofreram fragmentação durante a operação dos reatores e possivelmente isso tenha 
influenciado na eficiência de remoção do surfactante, uma vez que, ao longo da operação, a massa de suporte e consequente biomassa diminuíram.

Os valores de remoção do surfactante obtidos para essa configuração de reator foram muito satisfatórios uma vez que são inéditos na literatura. Degradação anaeróbia de LAS em reator horizontal de leito fixo atingiu valores de 28\% (OLIVEIRA et al., 2009) e 35\% (DUARTE et al., 2010) para concentração de 14 mg/L de LAS após 343 e 313 dias de operação, respectivamente. Em trabalho com reator operado em bateladas sequenciais, com biomassa granular, utilizando o mesmo inóculo, Duarte e colaboradores (2010) atingiram 53\% de degradação após 143 dias de operação e concentração de $22 \mathrm{mg} / \mathrm{L}$ de LAS.

A Tabela 5.9 apresenta os valores médios de LAS, sulfato e sulfeto nos afluente e efluente dos reatores durante as etapas III e VI de operação (alimentação com substrato sintético acrescido de LAS).

Tabela 5.9: Valores da concentração de LAS, sulfato e sulfeto afluente e efluente dos reatores de leito fluidificado durante etapas III e VI

\begin{tabular}{clccc}
\hline Reator & Amostra & $\begin{array}{c}\text { LAS } \\
(\mathbf{m g} / \mathbf{L})\end{array}$ & $\begin{array}{c}\text { Sulfato } \\
(\mathbf{m g} / \mathbf{L})\end{array}$ & $\begin{array}{c}\text { Sulfeto } \\
(\boldsymbol{\mu g} / \mathbf{L})\end{array}$ \\
\hline \multirow{2}{*}{ R1 (carvão } & Afluente & $14,7 \pm 4,9$ & $4 \pm 1$ & $93 \pm 48$ \\
ativado) & Efluente & $0,5 \pm 0,7$ & $18 \pm 10$ & $142 \pm 57$ \\
& Efic. $(\%)$ & $95 \pm 8$ & & \\
\hline \multirow{2}{*}{ R2 (argila } & Afluente & $13,4 \pm 3,0$ & $6 \pm 3$ & $126 \pm 92$ \\
expandida) & Efluente & $2,3 \pm 1,8$ & $17 \pm 13$ & $118 \pm 65$ \\
& Efic. $(\%)$ & $81 \pm 15$ & & \\
\hline \multirow{2}{*}{ R3 (pérolas } & Afluente & $18,8 \pm 4,2$ & $13 \pm 7$ & $96 \pm 39$ \\
de vidro) & Efluente & $0,2 \pm 0,3$ & $19 \pm 7$ & $56 \pm 52$ \\
& Efic. $(\%)$ & $99 \pm 2$ & & \\
\hline \multirow{2}{*}{ R4 (areia) } & Afluente & $18,8 \pm 4,2$ & $13 \pm 7$ & $96 \pm 39$ \\
& Efluente & $0,3 \pm 0,5$ & $22 \pm 11$ & $81 \pm 40$ \\
& Efic. $(\%)$ & $99 \pm 2$ & & \\
\hline
\end{tabular}

Em relação ao valores apresentados na Tabela 5.9 pode-se observar que, em todos os reatores, a concentração de sulfato efluente esteve maior que no afluente, em média, indicando a lise da molécula do LAS pelos microrganismos anaeróbios e liberação de sulfato no meio líquido. O sulfato disponível também pode ter sido utilizado pelos microrganismos para síntese como aparentemente ocorreu em reatores anaeróbios horizontais de leito fixo (Oliveira, et al., 2009), no qual, o comportamento 
observado foi o contrário, com concentrações de sulfato no efluente menores que no afluente ( $3 \mathrm{mg} / \mathrm{L}$ e $8 \mathrm{mg} / \mathrm{L}$, respectivamente).

Para sulfeto, tal comportamento não foi observado em todos os reatores, somente em R1 (carvão ativado). No entanto, deve-se notar, para todos os reatores, que são concentrações muito baixas $(\mu \mathrm{g} / \mathrm{L})$ e, apesar das análises terem sido realizadas em triplicata, existem os possíveis erros do método e de amostragem. $\mathrm{O}$ que se pode aferir com segurança sobre as concentrações de sulfeto é que são muito baixas no afluente e permaneceram assim no efluente.

\subsubsection{Balanço de Massa para LAS}

Ao final da operação dos reatores, amostras de material suporte foram retiradas para realização da extração do LAS adsorvido nos suportes. Com o valor da massa de LAS adsorvida no suporte e na biomassa, foi possível realizar cálculos de balanço de massa do sistema e determinar a fração de LAS degradada biologicamente.

Observou-se que aproximadamente $331 \mathrm{mg}$ de LAS entraram em R1, $12 \mathrm{mg}$ foram coletados no efluente e $34 \mathrm{mg}$ ficaram adsorvidos no carvão ativado e nas partículas finas no topo do reator resultando em $96 \%$ de remoção e $86 \%$ de degradação biológica. O Apêndice A apresenta algumas considerações quanto a presença de LAS adsorvido ao biofilme e sólidos.

O resultado da extração do LAS na argila expandida, realizado em triplicata, foi nulo, indicando que não houve adsorção do surfactante ao suporte mais biofilme, ou a quantidade foi muito pequena para ser detectada pelo método de cromatografia líquida. Assim, sabendo-se que cerca de $306 \mathrm{mg}$ de LAS foram adicionados ao reator R2 e $51 \mathrm{mg}$ saíram no efluente, pode-se concluir que $83 \%$ de LAS removidos foram degradados biologicamente.

Nos reatores R3 e R4 foram adicionados $385 \mathrm{mg}$ de LAS em cada um. No efluente do reator preenchido com pérolas de vidro (R3) e areia (R4) foram determinados $6 \mathrm{mg}$ e , $5 \mathrm{mg}$ de LAS, respectivamente. Ficaram adsorvidos 0,81 mg de LAS nas pérolas de vidro (R3) e 0,92 mg de LAS na areia (R4). Logo, a eficiencia de degradação foi de $98,5 \%$ e, 98,2\%, respectivamente, de todo o LAS adicionado.

Os resultados de adsorção nos reatores com os suportes pérolas de vidro e areia foram diferentes dos obtidos nos ensaios em batelada nos quais a adsorção foi nula. 
Porém, a massa de LAS adsorvida foi muito pequena e pode estar relacionada a biomassa que estava presente nos suportes dos reatores. Outro ponto importante referente a adsorção se apresentou mais acentuado no reator preenchido com carvão ativado (34 mg de LAS adsorvido). Acredita-se que essa massa de LAS adsorvida não esteja indisponível para os microrganismos e possivelmente será degradada e os sítios do suporte ficarão livres para outras moléculas do surfactante.

$\mathrm{Na}$ Tabela 5.10 e Figura 5.31 está apresentado o desempenho dos reatores na remoção de LAS.

Tabela 5.10: Balanço de massa de LAS

\begin{tabular}{ccccccc}
\hline Reator & Suporte & $\begin{array}{c}\text { Entrada } \\
(\mathbf{m g})\end{array}$ & $\begin{array}{c}\text { Saída } \\
(\mathbf{m g})\end{array}$ & $\begin{array}{c}\text { Remoção } \\
(\mathbf{\%})\end{array}$ & $\begin{array}{c}\text { Adsorvido } \\
(\mathbf{m g})\end{array}$ & $\begin{array}{c}\text { Degradação } \\
(\%)\end{array}$ \\
\hline R1 & $\begin{array}{c}\text { Carvão } \\
\text { ativado }\end{array}$ & 331 & 12 & 96 & 34 & 86 \\
R2 & $\begin{array}{c}\text { Argila } \\
\text { expandida }\end{array}$ & 306 & 51 & 83 & 0 & 83 \\
R3 & $\begin{array}{c}\text { Pérolas de } \\
\text { vidro }\end{array}$ & 385 & 5 & 99 & 0,81 & 98,5 \\
R4 & Areia & 385 & 6 & 98 & 0,92 & 98,2 \\
\hline
\end{tabular}

\section{Afluente $\square$ Efluente $\Delta \%$ Remoção}

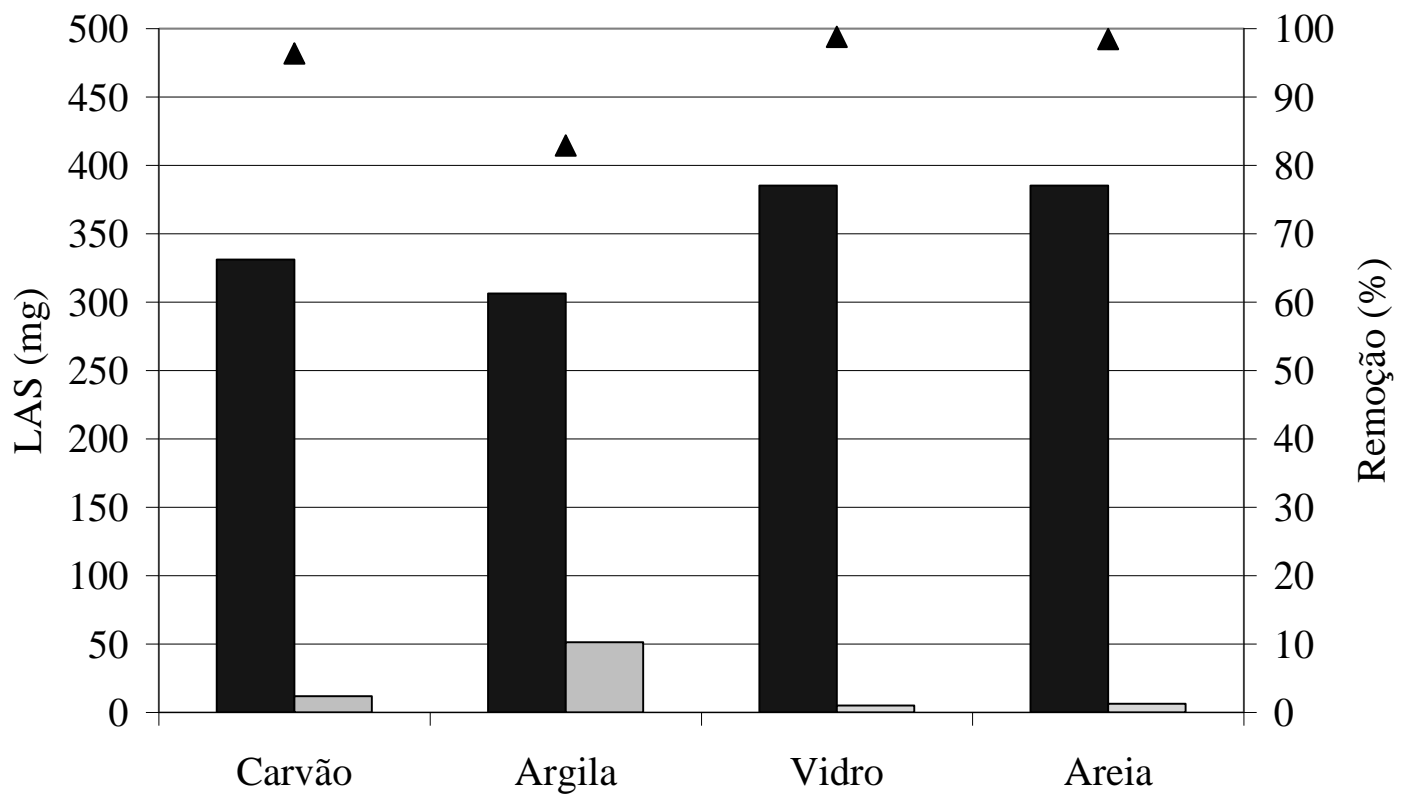

Figura 5.31: Valores de massas afluente e efluente e porcentagem de remoção de LAS em reatores em menor escala 
Oliveira et al., (2009), utilizando dois reatores anaeróbios horizontais de leito fixo (RAHLF), preenchidos com carvão vegetal (R1) e argila expandida e espuma de poliuretano (R2) como material suporte e inoculados com lodo de reator UASB utilizado no tratamento de dejetos de suinocultura, obtiveram $28 \%$ e $27 \%$, respectivamente, de degradação biológica de LAS após 343 dias de operação. Ao R1 foram adicionados cerca de $7854 \mathrm{mg}$ de LAS sendo $5461 \mathrm{mg}$ recuperados no efluente. Ensaios de extração de LAS do material suporte indicaram que 195 mg de LAS ficaram adsorvidos no biofilme. Assim, o balanço de massa resultou em $30 \%$ de remoção, sendo $28 \%$ de todo LAS adicionado removido por degradação Biológica.

Apesar do inóculo e substrato sintético dos reatores de Oliveira et al., (2009) serem iguais ao deste trabalho, os materiais suporte, configuração de reator, e tempo de operação foram diferentes, justificando a maior quantidade de LAS aplicada aos RHALFs. No entanto, quanto a adsorção e valores de remoção do surfactante, os reatores de leito fluidificado apresentaram valores mais elevados.

\subsection{Operação e Monitoramento do Reator Anaeróbio de Leito Fluidificado em Escala de Bancada}

\subsubsection{Imobilização e Adaptação da Biomassa}

$\mathrm{O}$ inóculo utilizado foi o mesmo usado nos reatores em menor escala. $\mathrm{O}$ procedimento de imobilização e adaptação da biomassa no reator de leito fluidificado em escala de bancada foi realizado da mesma maneira que nos reatores anteriores. Todavia, a biomassa foi imobilizada em areia em virtude dos bons resultados obtidos anteriormente nos reatores menores. O monitoramento da DQO filtrada está apresentado na Figura 5.32.

Ao longo do tempo, com o consumo da matéria orgânica pelos microrganismos anaeróbios presentes na fase líquida e no material suporte, novo substrato sintético era preparado e adicionado ao frasco contendo substrato antigo e lodo. Esses dias de suplementação estão marcados na Figura 5.32 por traços horizontais. Suplementação da alimentação foi preparada para manter o frasco em concentração de aproximadamente 500 mg/L. 


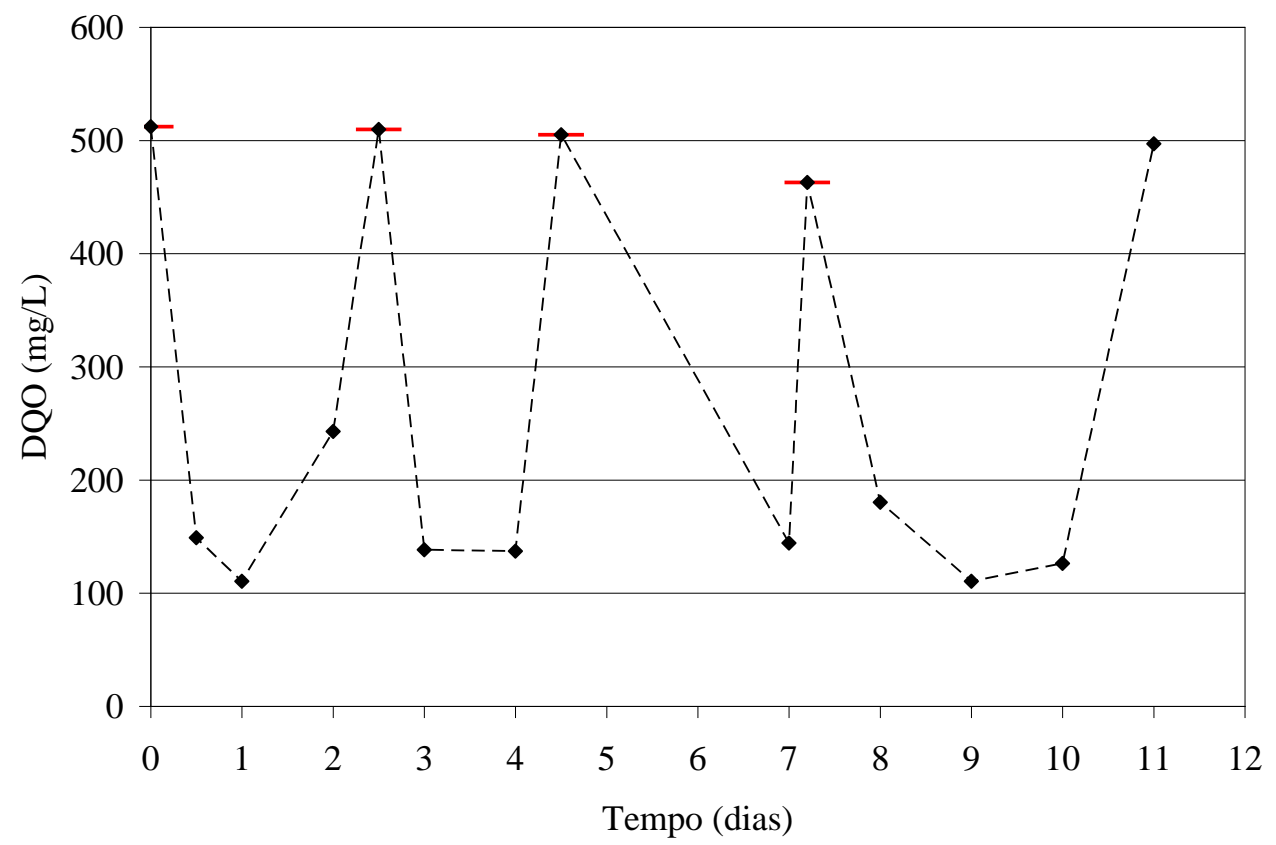

Figura 5.32: Variação temporal da DQO filtrada durante a inoculação do reator de leito fluidificado

\subsubsection{Remoção de Matéria Orgânica e LAS}

Durante a etapa I, o reator foi operado em circuito aberto. A alimentação consistiu somente de substrato sintético.

Nesta fase observou-se eficiência média de remoção de matéria orgânica (DQO filtrada) de $87 \pm 3 \%$, para concentração média afluente de $698 \pm 58 \mathrm{mg} / \mathrm{L}$, durante 28 dias de operação, conforme pode ser observado na Figura 5.33 e na Tabela 5.12

Após o período de alimentação com substrato sintético, deu-se início a etapa II de operação do reator com presença de LAS na alimentação em concentração de $8,2 \pm 1,3 \mathrm{mg} / \mathrm{L}$ por 28 dias. Os elevados valores obtidos para remoção de DQO filtrada nesta nova etapa $(86 \pm 7 \%$ em média, para concentração de $644 \pm 39 \mathrm{mg} / \mathrm{L})$ mostraram que a presença do surfactante não interferiu na degradação da matéria orgânica (Figura 5.33). Nessa etapa, a eficiência de remoção de LAS foi de $88 \%$ em média atingindo concentração efluente próxima ao limite de detecção da curva $(0,49 \mathrm{mg} / \mathrm{L})$.

Na Etapa III de operação a concentração de LAS na alimentação do reator foi de $24,4 \pm 3,7 \mathrm{mg} / \mathrm{L}$. A biomassa não foi prejudicada com o aumento da concentração do surfactante, uma vez que, a eficiência de degradação de matéria orgânica manteve-se 
elevada (91 $+3 \%$ ) (Figura 5.33) e a eficiência de remoção de LAS foi de $96 \pm 5 \%$ (Figura 5.34). A presente etapa teve duração de 49 dias.

Na Etapa IV, com duração de 49 dias a concentração de LAS na alimentação foi de $30,8 \pm 4,5 \mathrm{mg} / \mathrm{L}$. A porcentagem de remoção do surfactante manteve-se constante em

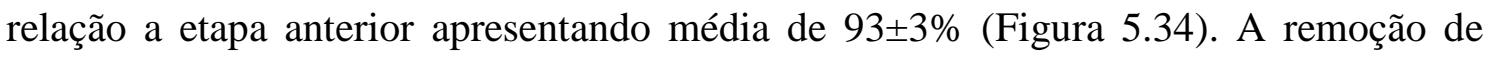
matéria orgânica permaneceu bastante eficiente com valor médio maior, em relação à etapa anterior de $93 \pm 2 \%$ (Figura 5.33).

A etapa V durou 70 dias com concentração de LAS afluente média de $38,4 \pm 5,7 \mathrm{mg} / \mathrm{L}$. A porcentagem de remoção do surfactante atingiu valores entre $87 \%$ e $100 \%$ e apresentou valor médio de $93 \pm 3 \%$, assim como na etapa anterior (Figura 5.34). O aumento da concentração de LAS não prejudicou a biomassa como podemos observar

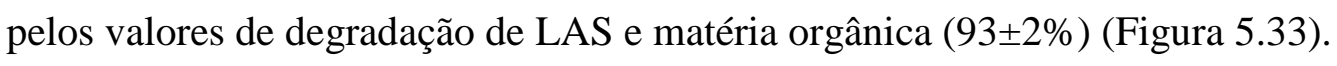

Na última etapa de operação do reator, com duração de 47 dias, ocorreu remoção de $93 \pm 3 \%$ de LAS para concentração afluente de 45,8 $\pm 5,4 \mathrm{mg} / \mathrm{L}$. Pode-se assim observar que o aumento gradual da concentração afluente de LAS não inibiu os microrganismos anaeróbios responsáveis por sua degradação (Figura 5.34). A matéria orgânica permaneceu com baixos valores efluentes $(60 \pm 17 \mathrm{mg} / \mathrm{L}$ de DQO filtrada), indicando remoção de $91 \pm 2 \%$, uma vez que a concentração afluente foi de $632 \pm 42 \mathrm{mg} / \mathrm{L}$ de DQO filtrada (Figura 5.33).

Os valores de remoção de LAS e matéria orgânica obtidos no reator de leito fluidificado foram bastante satisfatórios e superiores quando comparados aos trabalhos de Duarte et al. (2008, 2009) e Oliveira, et al. (2009) que avaliaram a degradação do surfactante em reator anaeróbio horizontal de leito fixo (RAHLF). No caso dos trabalhos citados, a concentração afluente do surfactante esteve em torno de $14 \mathrm{mg} / \mathrm{L}$ e o balanço de massa indicou remoção de $35 \%$ de todo o LAS adicionado ao sistema para reator preenchido com espuma de poliuretano como material suporte. Os demais reatores, que diferiam quanto ao material suporte (carvão vegetal e argila expandida) apresentaram eficiências inferiores. No entanto, quanto à remoção de matéria orgânica, o RAHLF se mostrou estável com remoção de mais de 90\%. A concentração afluente era semelhante ao do presente trabalho uma vez que o substrato sintético utilizado foi o mesmo. 


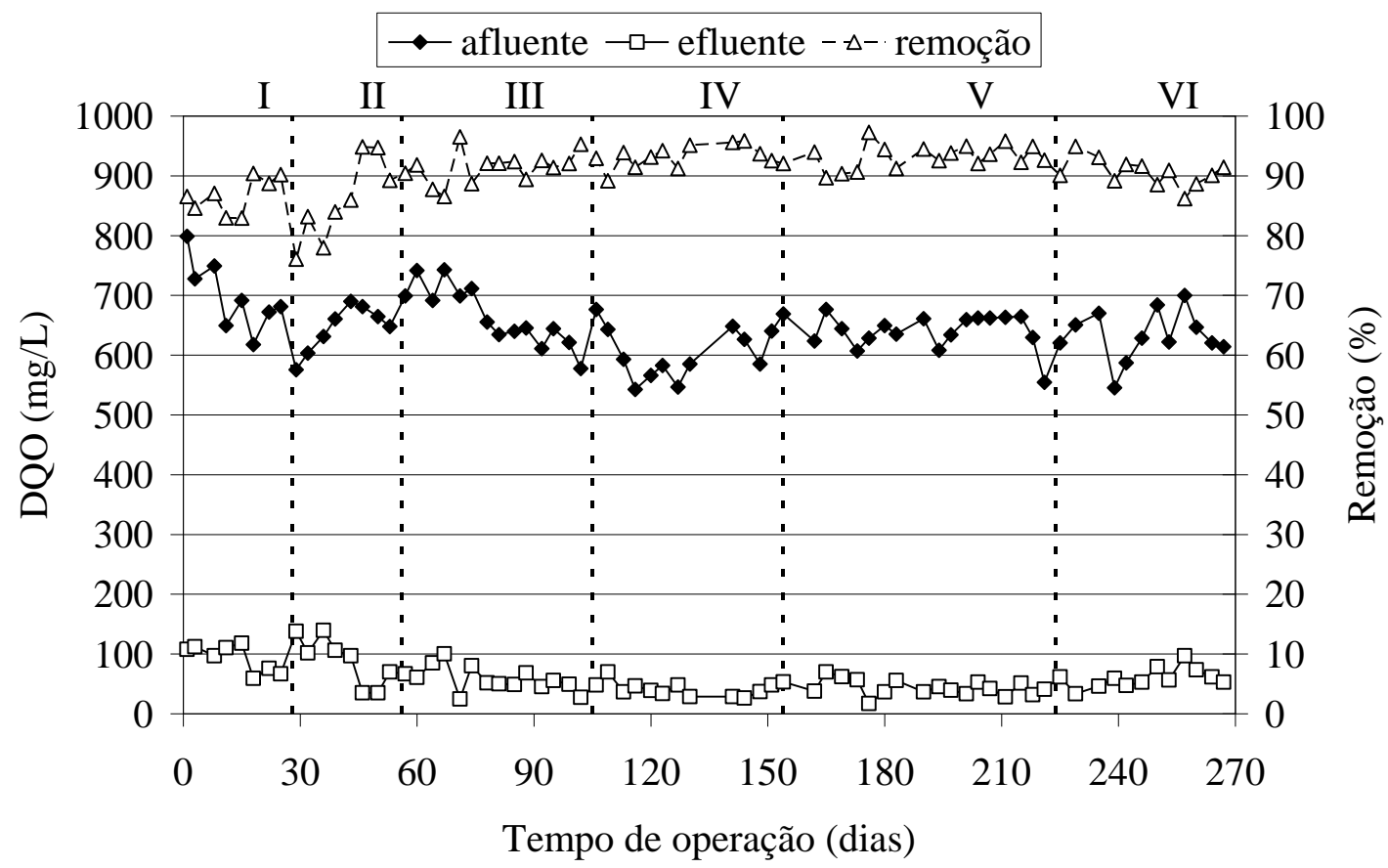

Figura 5.33: Variação temporal da DQO filtrada afluente e efluente e eficiência de remoção

Na Figura 5.34 são apresentadas as concentrações de LAS afluente e efluente, assim como os valores de eficiência de remoção do surfactante durante todo o período de operação.

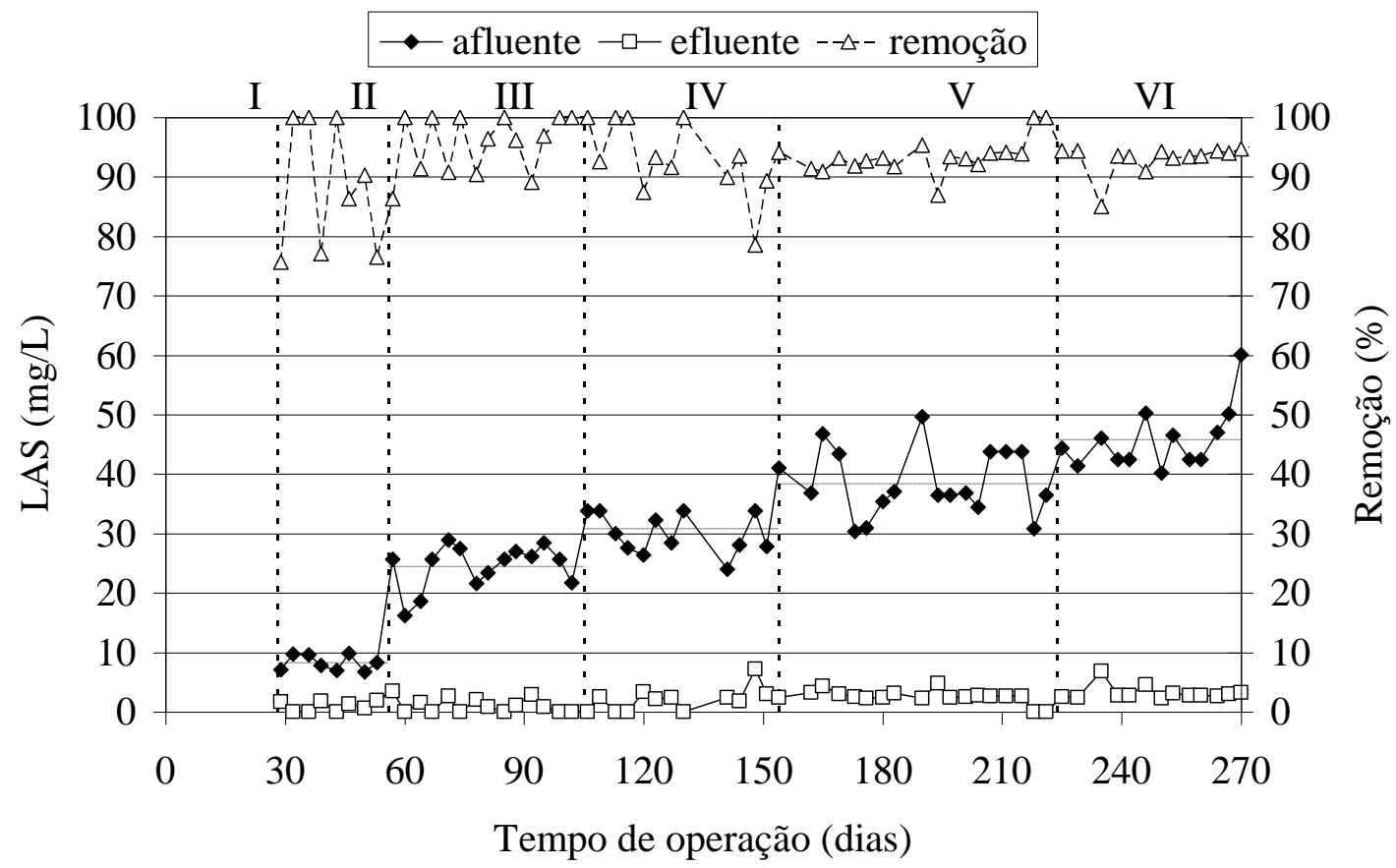

Figura 5.34: Variação temporal da concentração de LAS afluente e efluente 
O reator de leito fluidificado mostrou-se uma excelente opção para remoção do surfactante LAS quando comparado a outras configurações de reatores anaeróbios testados por outros pesquisadores (ASBR, UASB, RAHLF) (SANZ et al., 2003, ALMENDARIZ et al., 2001, LOBNER et al., 2005, DUARTE et al., 2008, OLIVEIRA et al., 2009, DUARTE et al., 2010). A alimentação contínua e o elevado tempo de detenção hidráulica, aliados à recirculação do sistema, auxiliaram na degradação anaeróbia de maior concentração do surfactante.

\subsubsection{Balanço de Massa}

Durante o período de operação, o reator recebeu cerca de $7.760 \mathrm{mg}$ de LAS e apenas $510 \mathrm{mg}$ foram coletadas no efluente. O restante (93\%) foi removido do sistema pelo processo de degradação biológica (Tabela 5.11).

O resultado da extração do LAS na areia, realizado em duplicata, foi inferior ao limite de detecção da curva de calibração $(0,49 \mathrm{mg} / \mathrm{L})$, indicando que não houve adsorção do surfactante ao suporte e biofilme.

Na Tabela 5.11 está apresentado o desempenho do reator na remoção de LAS.

Tabela 5.11: Balanço de massa de LAS

\begin{tabular}{ccccc}
\hline Entrada (mg) & Saída (mg) & Remoção (\%) & Adsorvido (mg) & Degradação (\%) \\
\hline 7760 & 510 & 93 & 0 & 93 \\
\hline
\end{tabular}

O reator em menor escala preenchido com areia (R4) recebeu cerca de $385 \mathrm{mg}$ de LAS e apenas $6 \mathrm{mg}$ foram coletadas no efluente. Houve 0,92 $\mathrm{mg}$ de LAS adsorvido, porém o restante $(98,2 \%)$ foi removido do sistema pelo processo de degradação biológica. Apesar da adsorção, o reator em menor escala apresentou maior porcentagem de remoção, possivelmente favorecida pela maior quantidade proporcional de material suporte usada no reator ( $60 \mathrm{~g}$ para reator com $350 \mathrm{ml}$ de volume e $430 \mathrm{~g}$ para reator com $1250 \mathrm{ml}$ de volume). 


\subsubsection{Considerações}

Até o final da década de 90, acreditava-se que o LAS não podia ser degradado por processos biológicos anaeróbios. No entanto, trabalhos recentes mostraram que tal biodegradação é possível, tais como, Almendariz et al. (2001) que obteve degradação de $41 \%$ e Sanz et al. (2003) com degradação de $85 \%$ em reatores UASB, além daqueles realizados por Duarte et al. (2008 e 2009) e Oliveira et al. (2009) que utilizaram reatores de leito fixo com biomassa imobilizada em materiais suporte e atingiram até $35 \%$ de degradação do surfactante.

Contudo, valores acima de $90 \%$ para degradação anaeróbia de LAS não foram encontrados na literatura, tornando inéditos os resultados desta pesquisa. Acredita-se então, que a biomassa imobilizada no material suporte, aliada ao sistema de mistura completa proporcionado pela fluidificação do leito, tenha favorecido o contato e biodisponibilidade do surfactante para os microrganismos em relação às outras configurações de reatores já utilizadas (UASB, ASBR, RAHLF - reator anaeróbio horizontal de leito fixo).

Reatores de leito fluidificado foram usados para tratar todo tipo de água residuária, desde esgoto (baixa DQO) a água residuária de produção de cerveja e açúcar (elevada DQO) (IZA, 1991). O efeito de diluição da recirculação e as excelentes características de transferência de massa dos reatores de leito fluidificado permitem o sistema operar sob tais condições. Outra vantagem do leito fluidificado é a grande superfície disponível para aderência nos materiais suporte, onde o microrganismo pode crescer, aumentando a concentração de biomassa (IZA, 1991).

No que se refere à toxicidade do surfactante aos microrganismos, a diluição inicial do afluente reduz a concentração do substrato e contribui para reduzir o efeito tóxico (IZA, 1991). Tal comportamento torna melhores os resultados de remoção quando comparado ao reator operado em bateladas sequenciais (ASBR) uma vez que, neste último, a biomassa recebe a concentração inicial de uma única vez.

Um dos fenômenos facilmente visualizados em reatores em escala de laboratório é a formação de grandes correntes verticais de partículas, algumas ascendentes, outras descendentes. As correntes não são relacionadas ao movimento aleatório típico de partículas em um leito fuidificado particulado mas inclinadas para as paredes do reator. Esse movimento de reciclagem interno não pode ser descrito matematicamente e, assim, 
a descrição da dispersão axial não é viável (IZA, 1991). O efeito prático deste comportamento é importante, contribuindo para melhor homogeneização do conteúdo do reator e expondo as partículas ao composto a ser degradado. Desse modo, quando comparado ao sistema de fluxo pistonado (RAHLF), o sistema de mistura homogênea proporciona maior disponibilidade da água residuária contendo LAS.

\subsubsection{Monitoramento de pH, Alcalinidade e Ácidos}

$\mathrm{Na}$ etapa I de operação do reator, somente com substrato sintético, os valores de pH mantiveram-se próximos ao neutro apresentando valor mínimo de 7,4 no afluente e máximo de 8,1 no efluente. O sistema apresentou alcalinidade efluente média de $289 \pm 125 \mathrm{mgCaCO}_{3} / \mathrm{L}$ representada como alcalinidade a bicarbonato. A concentração de ácidos voláteis totais (AVT) no efluente esteve entre 14 e 20 mgHAc/L.

Nas etapas seguintes, os parâmetros analisados permaneceram constantes e estáveis em relação à etapa anterior, quando da ausência de LAS na alimentação, conforme pode ser observado na Tabela 5.12

Tabela 5.12: Valores dos parâmetros físico-químicos afluente e efluente do reator de leito fluidificado durante as etapas de operação

\begin{tabular}{|c|c|c|c|c|c|c|c|}
\hline Etapa & Amostra & $\begin{array}{l}\mathrm{DQO}_{\mathrm{f}} \\
(\mathrm{mg} / \mathrm{L})\end{array}$ & pH & $\mathbf{A P}$ & $\left(\mathrm{mgCaCO}_{3} / \mathrm{L}\right)$ & L) & $\begin{array}{c}\mathrm{AVT} \\
(\mathrm{mgHAc} / \mathrm{L})\end{array}$ \\
\hline & Afluente & $698 \pm 58$ & $7,7 \pm 0,2$ & $186 \pm 26$ & $253 \pm 33$ & & \\
\hline I & $\begin{array}{l}\text { Efluente } \\
\text { Efic. (\%) }\end{array}$ & $\begin{array}{c}93 \pm 23 \\
87 \pm 3\end{array}$ & $8,1 \pm 0,2$ & $229 \pm 93$ & $299 \pm 125$ & $289 \pm 125$ & $17 \pm 2$ \\
\hline II & $\begin{array}{l}\text { Afluente } \\
\text { Efluente } \\
\text { Efic. }(\%)\end{array}$ & $\begin{array}{c}644 \pm 39 \\
90 \pm 41 \\
86 \pm 7 \\
\end{array}$ & $\begin{array}{l}7,6 \pm 0,2 \\
8,1 \pm 0,2\end{array}$ & $\begin{array}{l}198 \pm 19 \\
130 \pm 16\end{array}$ & $\begin{array}{l}268 \pm 19 \\
164 \pm 15\end{array}$ & $151 \pm 17$ & $18 \pm 6$ \\
\hline III & $\begin{array}{l}\text { Afluente } \\
\text { Efluente } \\
\text { Efic. }(\%)\end{array}$ & $\begin{array}{c}665 \pm 50 \\
58 \pm 21 \\
91 \pm 3\end{array}$ & $\begin{array}{l}7,7 \pm 0,1 \\
8,0 \pm 0,2\end{array}$ & $\begin{array}{c}200 \pm 14 \\
122 \pm 9\end{array}$ & $\begin{array}{l}164 \pm 14 \\
154 \pm 13\end{array}$ & $143 \pm 12$ & $15 \pm 3$ \\
\hline IV & $\begin{array}{l}\text { Afluente } \\
\text { Efluente } \\
\text { Efic. }(\%)\end{array}$ & $\begin{array}{c}608 \pm 45 \\
42 \pm 12 \\
93 \pm 2\end{array}$ & $\begin{array}{l}7,7 \pm 0,2 \\
8,0 \pm 0,2\end{array}$ & $\begin{array}{l}182 \pm 32 \\
132 \pm 36\end{array}$ & $\begin{array}{l}240 \pm 41 \\
161 \pm 43\end{array}$ & $152 \pm 43$ & $12 \pm 3$ \\
\hline V & $\begin{array}{l}\text { Afluente } \\
\text { Efluente } \\
\text { Efic. }(\%)\end{array}$ & $\begin{array}{c}639 \pm 30 \\
43 \pm 13 \\
93 \pm 2 \\
\end{array}$ & $\begin{array}{l}7,6 \pm 0,3 \\
8,1 \pm 0,2\end{array}$ & $\begin{array}{l}182 \pm 22 \\
128 \pm 21\end{array}$ & $\begin{array}{l}245 \pm 23 \\
157 \pm 27\end{array}$ & $146 \pm 6$ & $15 \pm 5$ \\
\hline VI & $\begin{array}{l}\text { Afluente } \\
\text { Efluente } \\
\text { Efic. }(\%)\end{array}$ & $\begin{array}{c}632 \pm 42 \\
60 \pm 17 \\
91 \pm 2\end{array}$ & $\begin{array}{l}7,6 \pm 0,2 \\
7,9 \pm 0,2\end{array}$ & $\begin{array}{l}187 \pm 15 \\
130 \pm 37\end{array}$ & $\begin{array}{l}255 \pm 22 \\
158 \pm 43\end{array}$ & $153 \pm 47$ & $14 \pm 6$ \\
\hline
\end{tabular}


Na etapa II, os valores de $\mathrm{pH}$ mantiveram-se próximos ao neutro apresentando valor mínimo de 7,4 afluente e máximo de 8,3 efluente. O sistema apresentou alcalinidade efluente média de $151 \pm 17 \mathrm{mgCaCO}_{3} / \mathrm{L}$ representada como alcalinidade a bicarbonato, menor que na etapa anterior. A concentração de ácidos voláteis totais (AVT) efluente esteve entre 13 e $31 \mathrm{mgHAc} / \mathrm{L}$.

$\mathrm{Na}$ etapa III os valores de $\mathrm{pH}$ mantiveram-se constantes apresentando valor mínimo de 7,5 afluente e máximo de 8,2 efluente. O sistema apresentou alcalinidade efluente média de $143 \pm 12 \mathrm{mgCaCO}_{3} / \mathrm{L}$ representada como alcalinidade a bicarbonato. A concentração de ácidos voláteis totais (AVT) efluente esteve entre 12 e 21 mgHAc/L.

$\mathrm{Na}$ etapa IV, pH variou de 7,3 a 8,1 no afluente e de 7,3 a 8,4 no efluente. Alcalinidade a bicarbonato no efluente do sistema variou de 68 a $268 \mathrm{mgCaCO}_{3} / \mathrm{L}$, com valor médio de $152 \pm 43 \mathrm{mgCaCO}_{3} / \mathrm{L}$. A concentração média de ácidos voláteis foi $12 \pm 3 \mathrm{mgHAc} / \mathrm{L}$.

Novamente, na etapa $\mathrm{V}$, os valores de $\mathrm{pH}$, alcalinidade a bicarbonato e ácidos voláteis mantiveram-se estáveis (Tabela 5.12). pH afluente e efluente manteve-se próximo ao neutro variando entre 7,1 e 8,5 . Alcalinidade a bicarbonato variou entre $117 \mathrm{mgCaCO}_{3} / \mathrm{L}$ e $230 \mathrm{mgCaCO}_{3} / \mathrm{L}$ e ácidos totais voláteis entre $1 \mathrm{mgHAc} / \mathrm{L} \mathrm{e}$ $24 \mathrm{mgHAc} / \mathrm{L}$.

$\mathrm{Na}$ última etapa de operação (Etapa VI) os valores de $\mathrm{pH}$ mantiveram-se próximos ao neutro apresentando valor mínimo de 7,4 no afluente e máximo de 8,3 no efluente. $\mathrm{O}$ sistema apresentou alcalinidade efluente média de $153 \pm 47 \mathrm{mgCaCO}_{3} / \mathrm{L}$ representada como alcalinidade a bicarbonato. A concentração de ácidos voláteis totais (AVT) média efluente foi de $14 \pm 6 \mathrm{mgHAc} / \mathrm{L}$. Em todas as etapas, os valores de cada parâmetro analisado se mantiveram muito próximos indicando a estabilidade do reator.

Nas Figuras seguintes (Figura 5.35 a Figura 5.39) estão apresentados os resultados de monitoramento de rotina durante toda a operação do reator quanto a $\mathrm{pH}$, alcalinidades parcial, total, a bicarbonato e ácidos voláteis totais, cujos valores foram sumarizados na Tabela 5.12. 


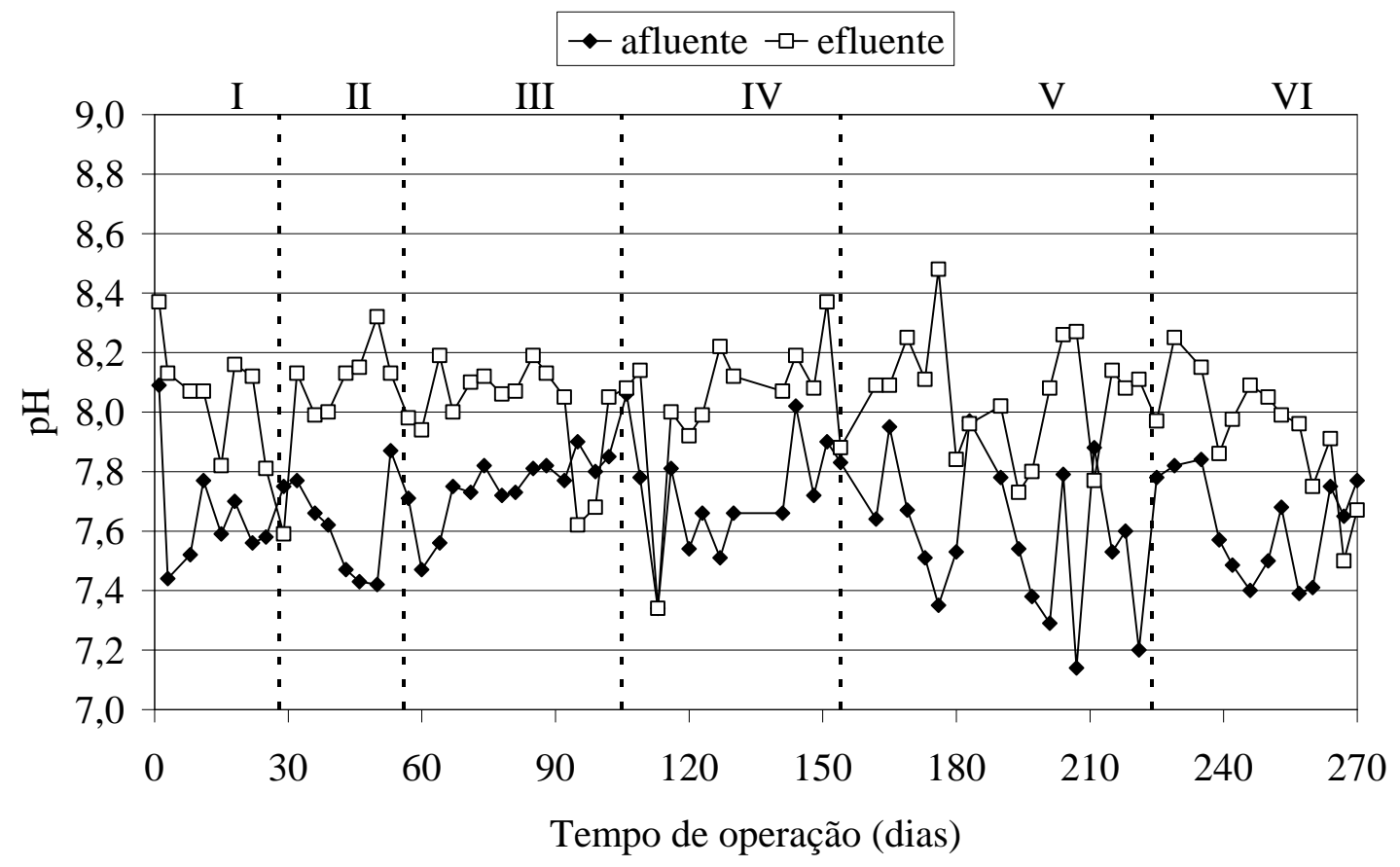

Figura 5.35: Variação temporal do $\mathrm{pH}$ afluente e efluente

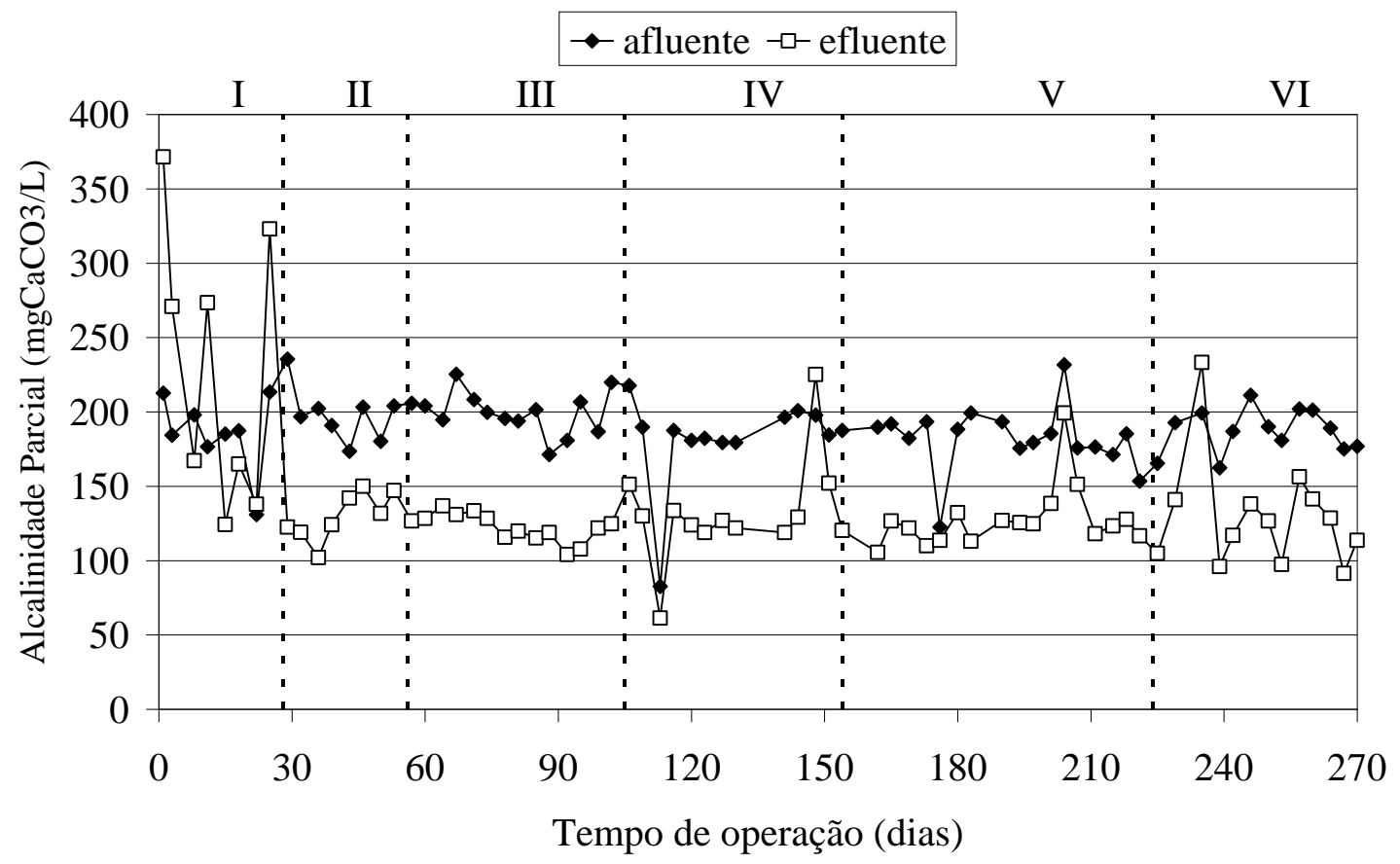

Figura 5.36: Variação temporal da alcalinidade parcial afluente e efluente 


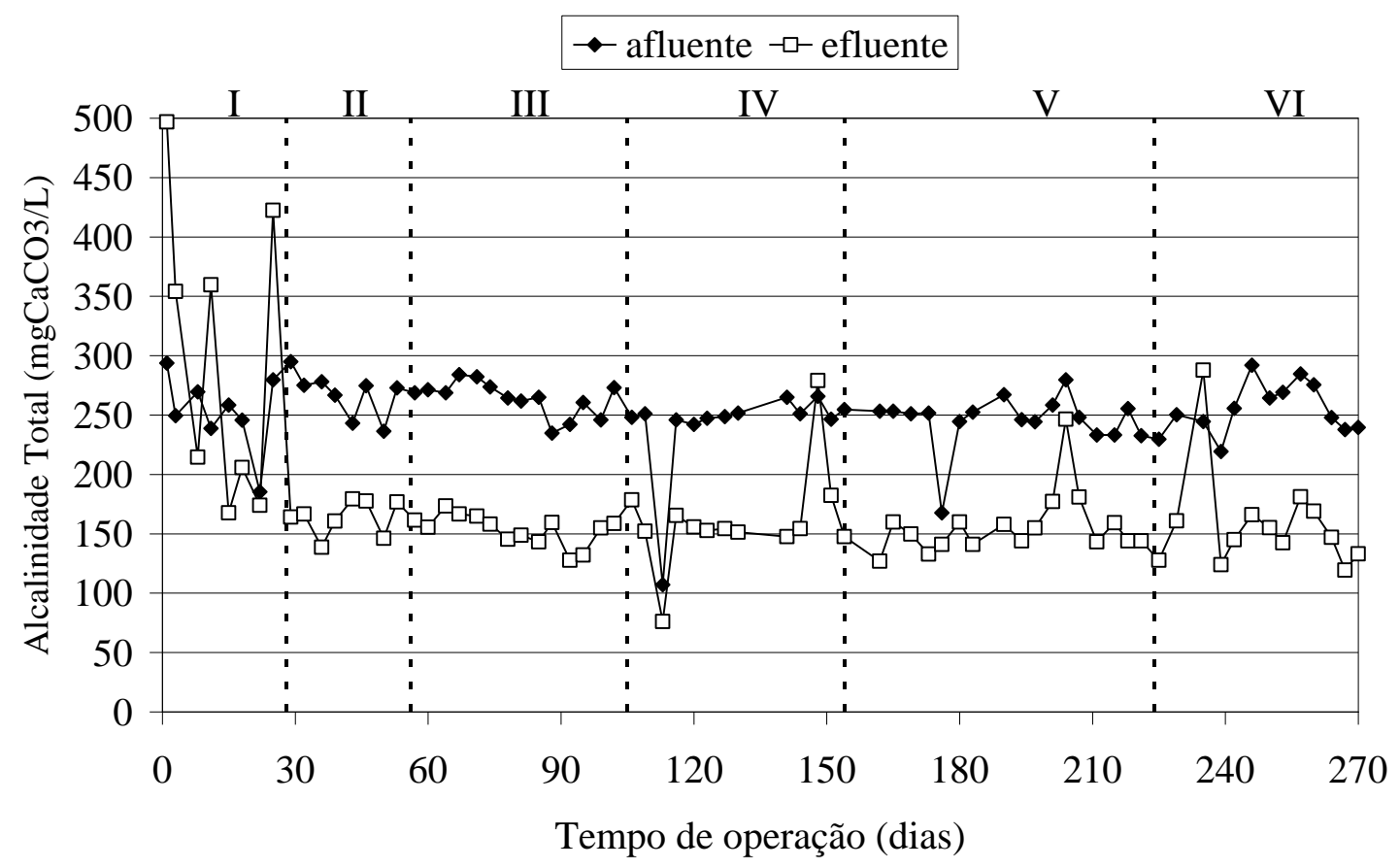

Figura 5.37: Variação temporal da alcalinidade total afluente e efluente

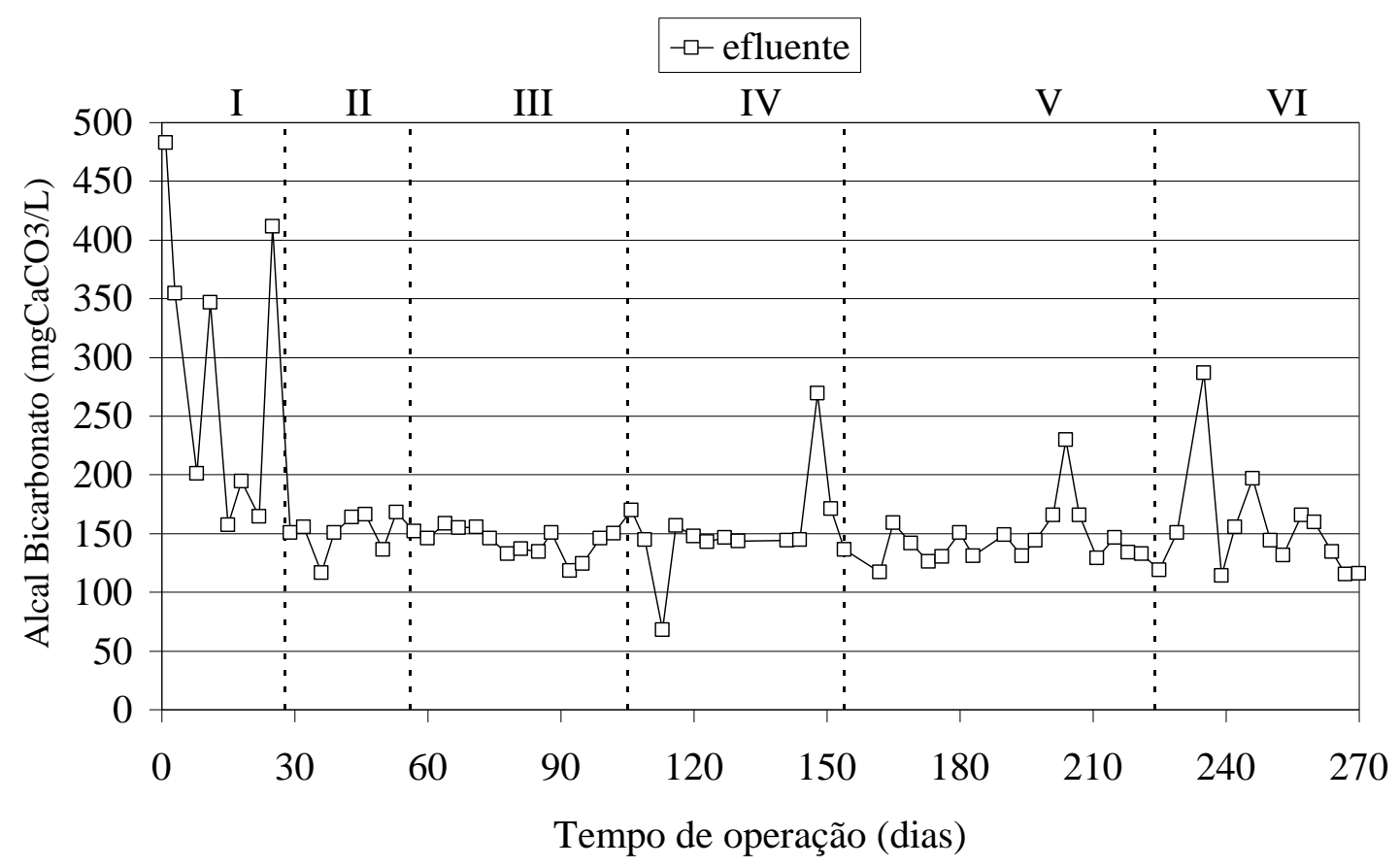

Figura 5.38: Variação temporal da alcalinidade a bicarbonato efluente 


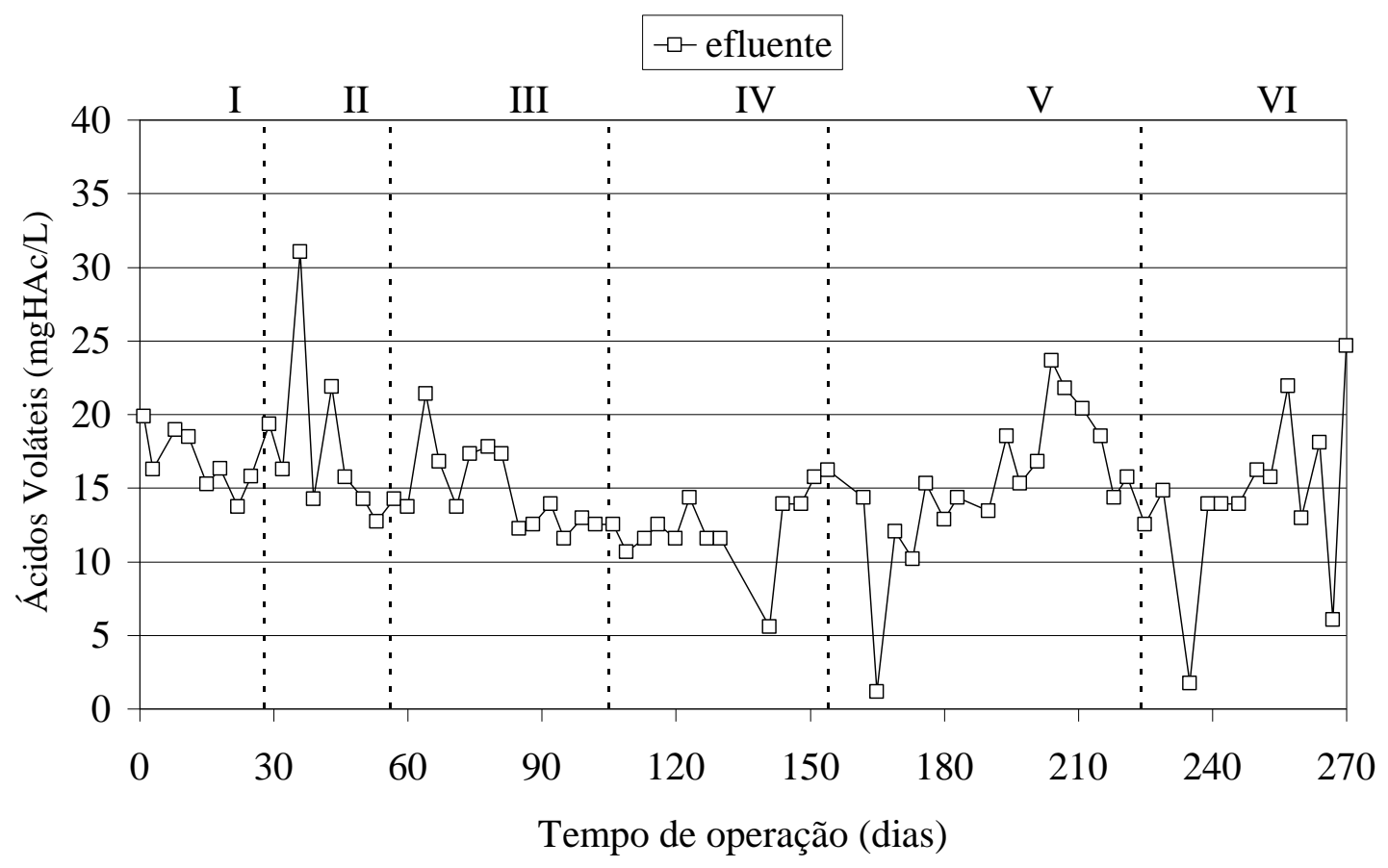

Figura 5.39: Variação temporal de ácidos voláteis totais efluente

\subsubsection{Sulfato e Sulfeto}

Após adição do surfactante a alimentação, também foi monitorada a concentração de sulfato e sulfeto afluente e efluente do reator.

A Tabela 5.13 apresenta os valores médios de LAS, sulfato e sulfeto afluente e efluente do reator durante as etapas II, III, IV, V, e VI de operação.

Os valores de LAS efluente foram baixos quando comparados aos valores afluente e elevadas foram as porcentagens de remoção. No entanto, os valores médios efluente em casa etapa encontram-se acima do valor estabelecido pela resolução CONAMA N³57/2005 de 0,5 mg/L LAS como "substânicas tensoativas que reagem com o azul de metileno".

Analisando a Tabela 5.13 pode-se observar que, quanto aos valores de sulfato, a concentração efluente esteve maior que no afluente, em média, indicando a lise da molécula do LAS pelos microrganismos anaeróbios e liberação de sulfato no meio líquido, da mesma maneira que ocoreu nos reatores em menor escala.

Para sulfeto, tal comportamento apenas foi observado na etapa III. No entanto, deve-se notar, para todas as etapas, que são concentrações muito baixas (em $\mu \mathrm{g} / \mathrm{L}$ ) e, apesar das análises terem sido realizadas em triplicata, existem os possíveis erros do 
método e de amostragem. O que se pode aferir com segurança sobre as concentrações de sulfeto é que são muito baixas no afluente e permanecem assim no efluente.

Tabela 5.13: Concentração de LAS, sulfato e sulfeto afluente e efluente durante etapas II a VI

\begin{tabular}{ccccc}
\hline Etapa & Amostra & $\begin{array}{c}\text { LAS } \\
(\mathbf{m g} / \mathbf{L})\end{array}$ & $\begin{array}{c}\text { Sulfato } \\
(\mathbf{m g} / \mathbf{L})\end{array}$ & $\begin{array}{c}\text { Sulfeto } \\
(\boldsymbol{\mu g} / \mathbf{L})\end{array}$ \\
\hline \multirow{3}{*}{ II } & Afluente & $8,2 \pm 1,3$ & $5 \pm 3$ & $102 \pm 102$ \\
& Efluente & $0,9 \pm 0,9$ & $16 \pm 5$ & $158 \pm 115$ \\
& Efic. (\%) & $88 \pm 11$ & & \\
\hline \multirow{3}{*}{ III } & Afluente & $24,4 \pm 3,7$ & $12 \pm 4$ & $127 \pm 80$ \\
& Efluente & $1,1 \pm 1,2$ & $33 \pm 9$ & $40 \pm 32$ \\
& Efic. (\%) & $96 \pm 5$ & & \\
\hline \multirow{2}{*}{ IV } & Afluente & $30,8 \pm 4,5$ & $12 \pm 6$ & $135 \pm 113$ \\
& Efluente & $2,1 \pm 2,0$ & $28 \pm 8$ & $115 \pm 130$ \\
& Efic. (\%) & $93 \pm 6$ & & \\
\hline \multirow{2}{*}{ V } & Afluente & $38,4 \pm 5,7$ & $18 \pm 9$ & $465 \pm 396$ \\
& Efluente & $2,5 \pm 1,2$ & $23 \pm 5$ & $218 \pm 252$ \\
& Efic. (\%) & $93 \pm 3$ & & \\
\hline & Afluente & $45,8 \pm 5,4$ & $23 \pm 9$ & $341 \pm 222$ \\
VI & Efluente & $3,2 \pm 1,2$ & $30 \pm 8$ & $221 \pm 164$ \\
& Efic. (\%) & $93 \pm 3$ & & \\
\hline
\end{tabular}

Em trabalhos sobre degradação de LAS em reatores horizontais de leito fixo (Duarte, 2006 e Oliveira, 2006), a concentração de sulfato e sulfeto foi monitorada ao longo dos reatores. Foi observado que para concentração inicial de $14 \mathrm{mg} / \mathrm{L}$ de LAS em substrato sintético semelhante ao do presente trabalho, a concentração máxima de sulfato se encontrava no primeiro trecho do reator $(16 \mathrm{mg} / \mathrm{L})$ e decrescia ao longo do reator até o efluente $(2 \mathrm{mg} / \mathrm{L})$. No entanto, ao final da operação dos reatores, quando foram retiradas as fontes de carbono da alimentação, exceto LAS, a concentração inicial de sulfato $(11 \mathrm{mg} / \mathrm{L})$ aumentou ao longo do reator, atingindo $16 \mathrm{mg} / \mathrm{L}$ no efluente. A concentração de sulfeto também aumentou ao longo do reator após a retirada das fontes orgânicas passando de zero no afluente a $1,5 \mathrm{mg} / \mathrm{L}$ no efluente.

Quanto aos valores de sulfeto, os trabalhos citados apresentaram concentrações próximas as encontradas nos reatores de leito fluidificado. Sulfeto esteve presente em maior quantidade no efluente dos reatores porém em baixas concentrações ao longo dos reatores, como no presente trabalho. 


\subsection{Exames Microscópicos}

\subsubsection{Reatores em Menor Escala}

Ao final da operação dos reatores preenchidos com pérolas e vidro e areia foram retiradas amostras do material suporte para realização de exames microscópicos de contraste de fase. Assim, foi possível verificar a presença e diversidade de morfologias microbianas nos reatores.

Mantiveram-se presentes nos reatores células já encontradas no inóculo, tais como bacilos e cocos, além da presença de bactérias formadoras de endósporos (Figura $5.40)$.

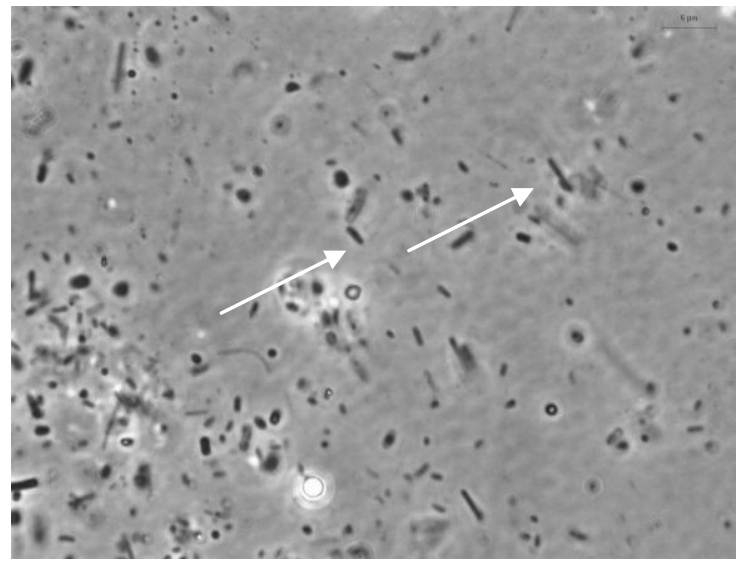

(a)

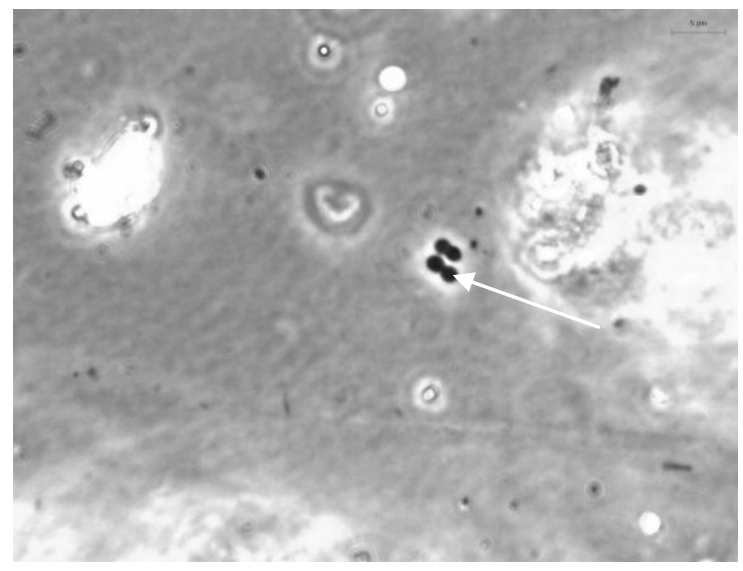

(c)

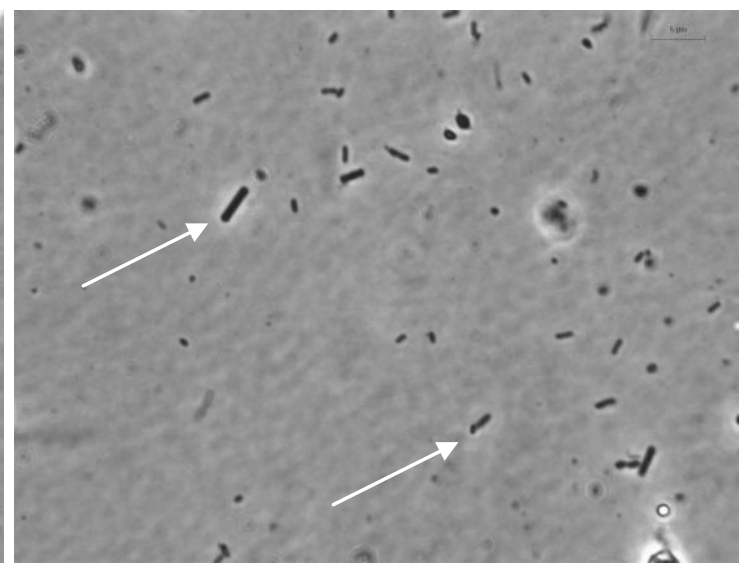

(b)

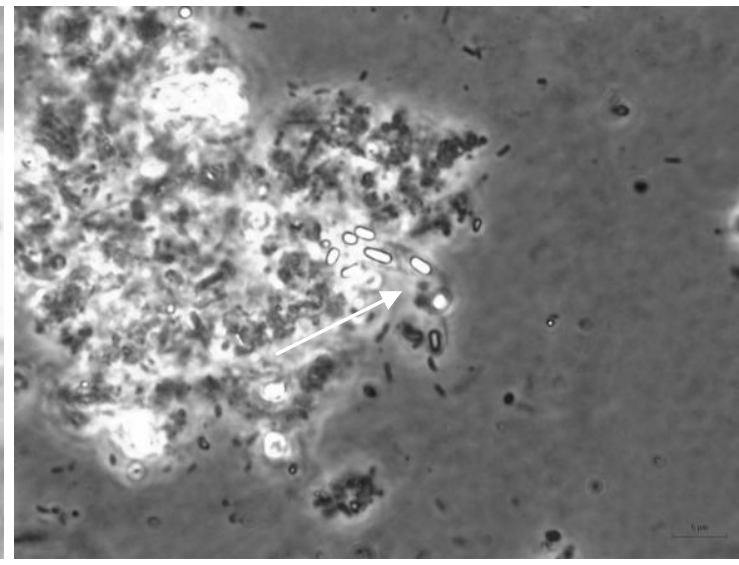

(d)

Figura 5.40: Microscopia de contraste de fase das morfologias observadas em R3 e R4:

(a) e (b) bacilos, (c) cocos, (d) endósporos 


\subsubsection{Reator em Escala de bancada}

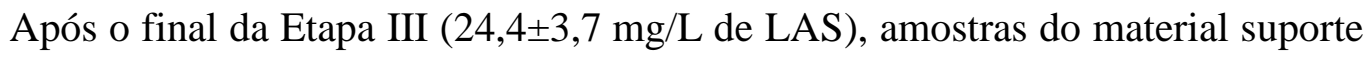
foram retiradas do reator para realização de exames microscópicos.

Nesta fase foram observadas células com morfologias semelhantes a espiroquetas, bacilos e bactérias filamentosas, além de raros bacilos fluorescentes semelhantes a arquéias metanogênicas (Figura 5.41).

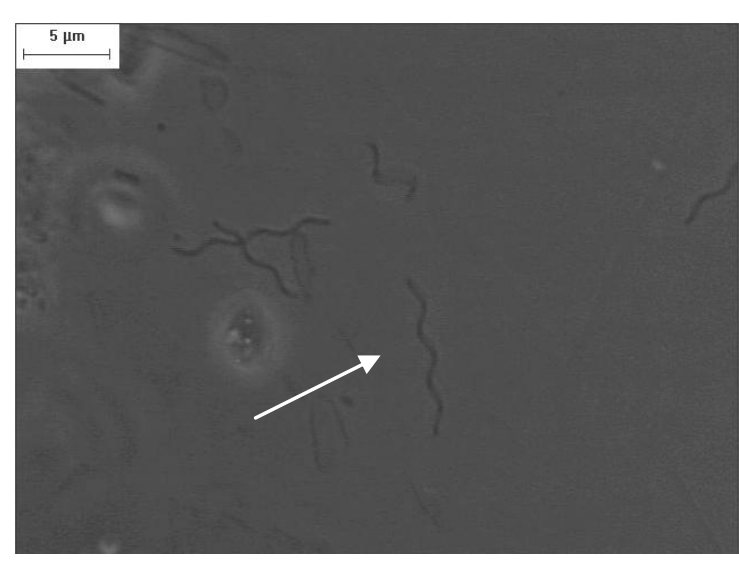

(a)

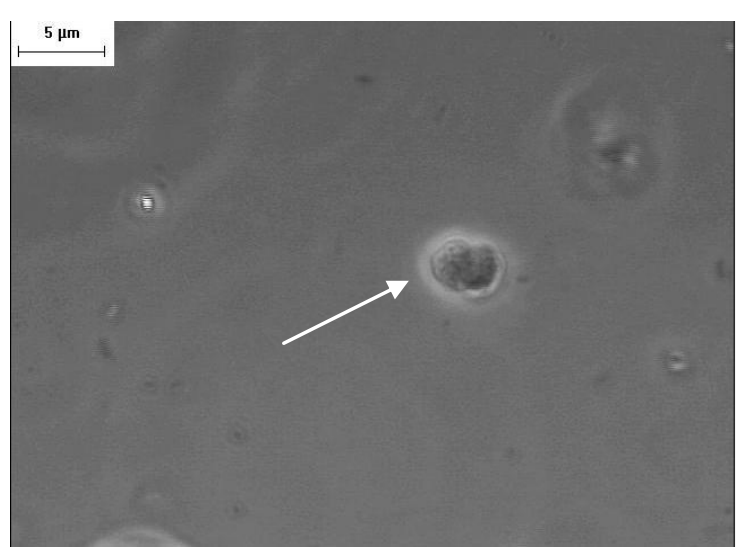

(c)

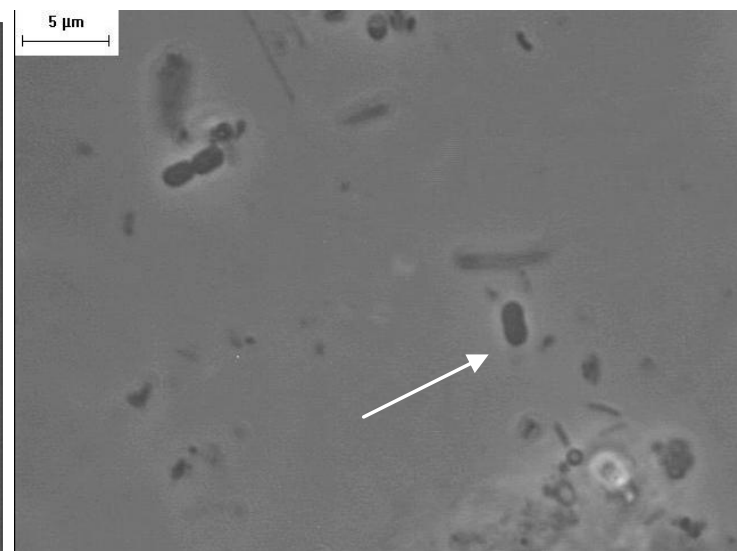

(b)

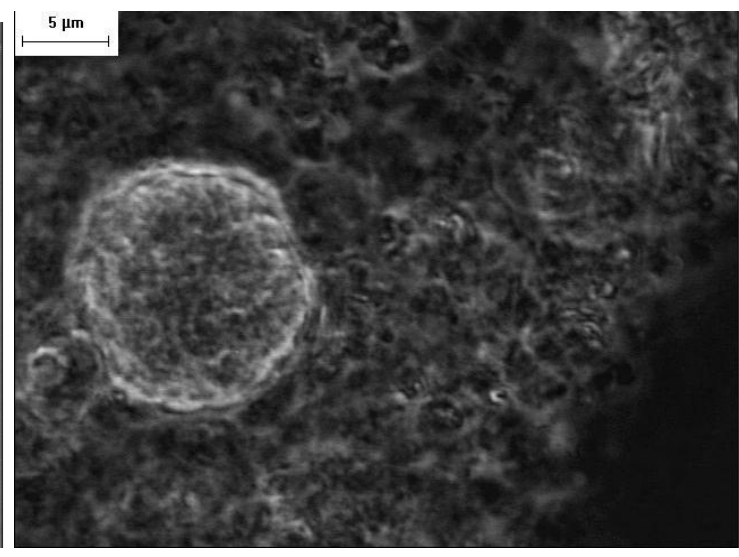

(d)

Figura 5.41: Microscopia de contraste de fase das morfologias observadas no reator em escala de bancada após Etapa III: (a) espiroquetas, (b) bacilos, (c) sarcinas, (d) cisto

A presença de cistos chamou a atenção por esse tipo de comportamento ser típico de arquéias metanogênicas semelhantes a Methanosarcina.

Após o final da Etapa V (38,4 $\pm 5,7 \mathrm{mg} / \mathrm{L}$ de LAS) amostras do material suporte foram novamente retiradas do reator para realização de exames microscópicos. As morfologias encontradas assemelharam-se às anteriores, todavia, com predominância 
de cocos, Novamente, foram encontrados espiroquetas, além de variedade de bacilos e bacilos curvos (Figura 5.42).

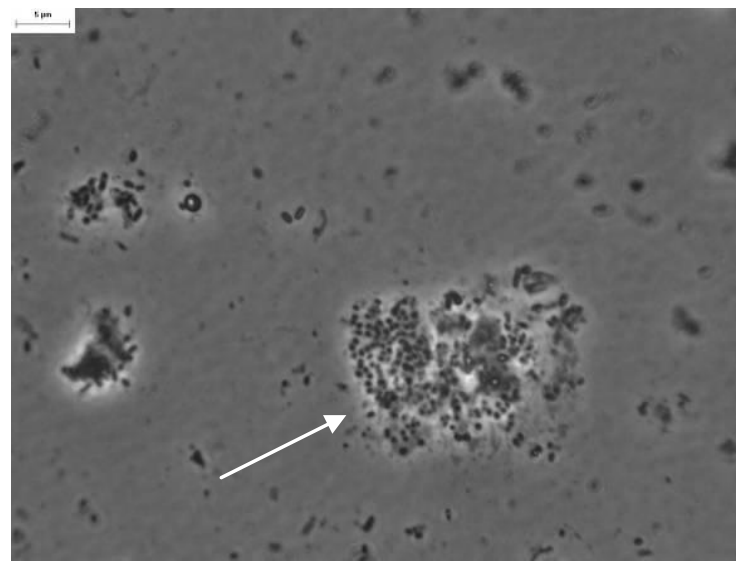

(a)

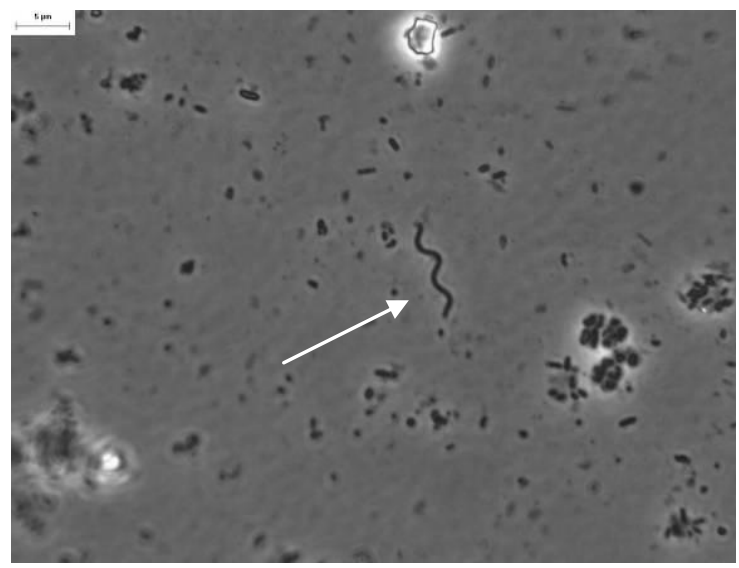

(c)

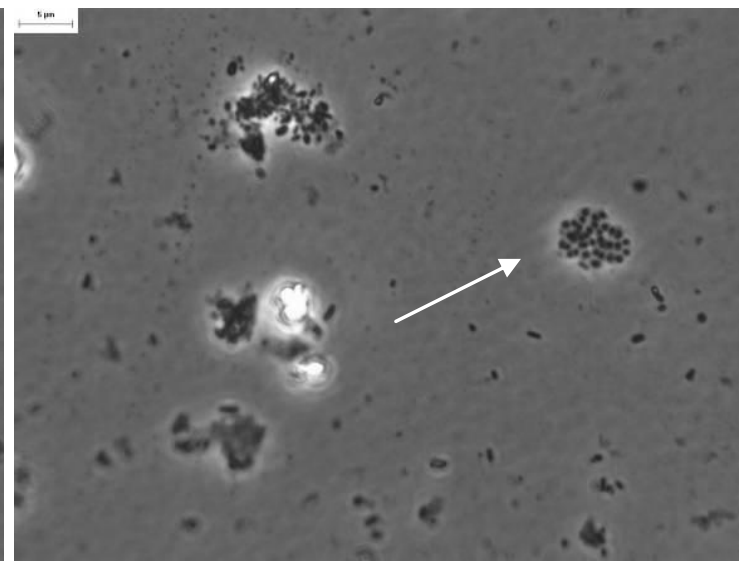

(b)

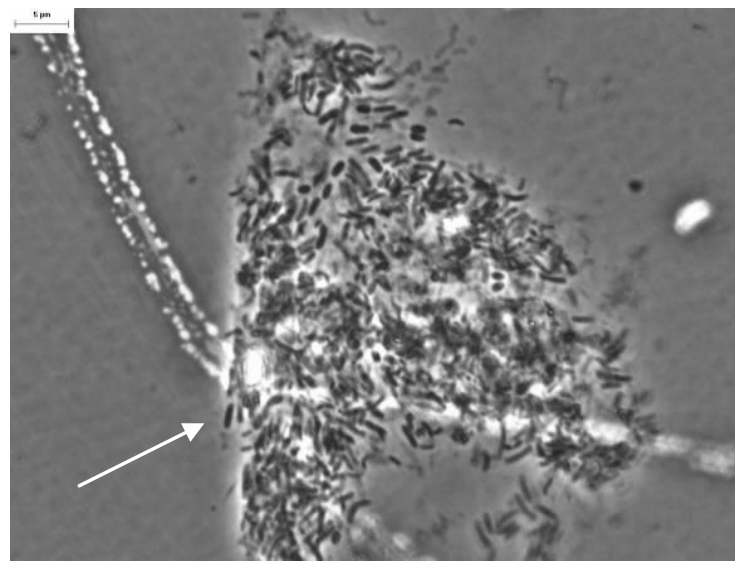

(d)

Figura 5.42: Microscopia de contraste de fase das morfologias observadas no reator em escala de bancada após Etapa V: (a) e (b) cocos, (c) espiroqueta, (d) bacilos

Além dessas morfologias foram observadas com menor freqüência bactérias filamentosas e morfologia semelhante a Methanosarcina.

Após o final da operação do reator $(45,8 \pm 5,4 \mathrm{mg} / \mathrm{L}$ de LAS) novas amostras do biofilme foram analisadas em microscópio óptico. Foram encontradas diversas morfologias microbianas, tais como, cocos, espiroquetas, bactérias filamentosas, bacilos retos e curvos e endósporos. Nessa condição em que se encontrava o reator também foi possível detectar bacilos e morfologias semelhantes à Methanosarcina indicando a presença de arquéias metanogênicas que são microrganismos estritamente anaeróbios. 


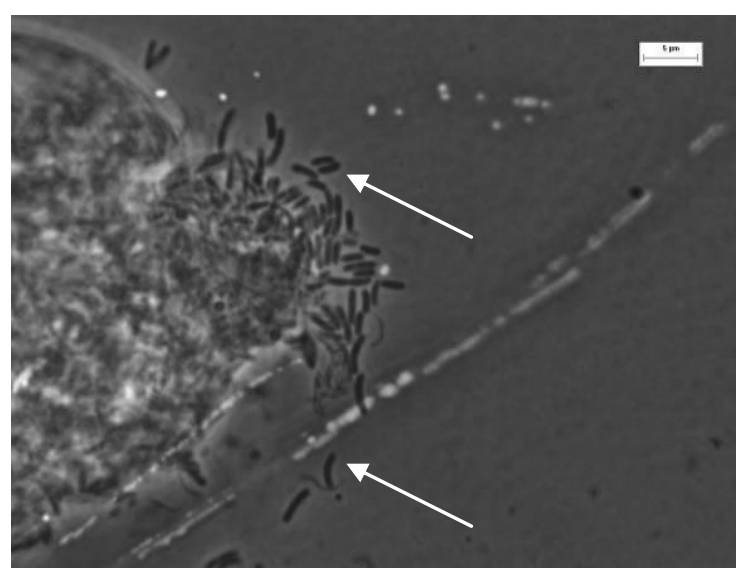

(a)

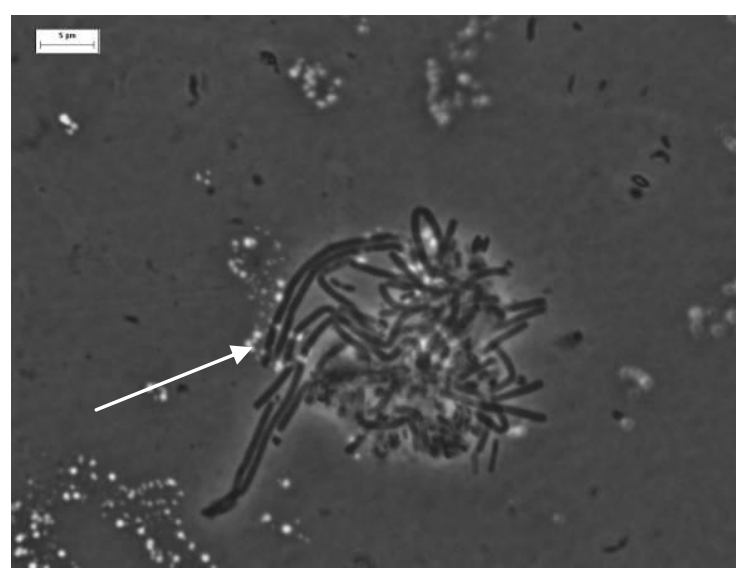

(c)

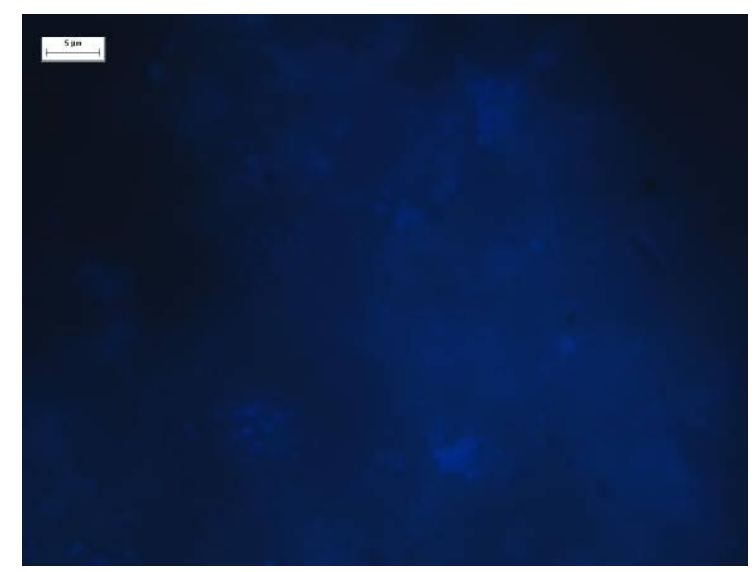

Figura 5.43: Microscopia de contraste de fase das morfologias observadas no reator em escala de bancada ao final da operação: (a) bacilos retos e curvos, (b) cocos, (c) filamentosas, (d) espiroqueta, (e) bacilos fluorescentes

Durante todo o processo de operação do reator foi observada grande diversidade de grupos bacterianos, corroborando a hipótese de que a degradação do LAS é decorrente de consórcio microbiano.

A caracterização morfológica da biomassa presente no reator está sintetizada naTabela 5.14 
Tabela 5.14: Morfologias observadas em microscopia de contraste de fase e fluorescência

\begin{tabular}{lcccc}
\hline Morfologias & Inóculo & Etapa III & Etapa V & Final \\
\hline Cocos & +++ & +++ & +++ & ++++ \\
Espiroquetas & ++ & +++ & ++++ & +++ \\
Filamentosas & ++ & ++ & ++ & + \\
Endósporos & + & - & + & + \\
Bacilos retos & +++ & ++ & +++ & +++ \\
Bacilos curvos & +++ & ++ & +++ & +++ \\
Bacilos fluorescentes & - & - & - & + \\
Sarcinas fluorescentes & - & ++ & + & - \\
\hline \multicolumn{2}{c}{$(++++)$ predominantes; $(+++)$} & frequientes; $(++)$ pouco frequientes; $(+)$ raros; $(-)$ não
\end{tabular}

$(++++)$ predominantes; $(+++)$ freqüentes; $(++)$ pouco freqüentes; $(+)$ raros; $(-)$ não

foram observados

Em materiais suporte com biomassa imobilizada empregados em reatores de leito fixo para degradação anaeróbia de LAS (Duarte, 2006 e Oliveira, 2006) foram observadas morfologias semelhantes as encontradas nos reatores de leito fluidificado indicando a necessidade da presença destes microrganismos para remoção de matéria orgânica e surfactante.

Da mesma maneira que a microscopia de contraste de fase, a microscopia eletrônica de varredura revelou biofilme estabelecido na areia, sendo possível observar elevada densidade de células microbianas e camada de exopolímero cobrindo o suporte (Figura 5.44).

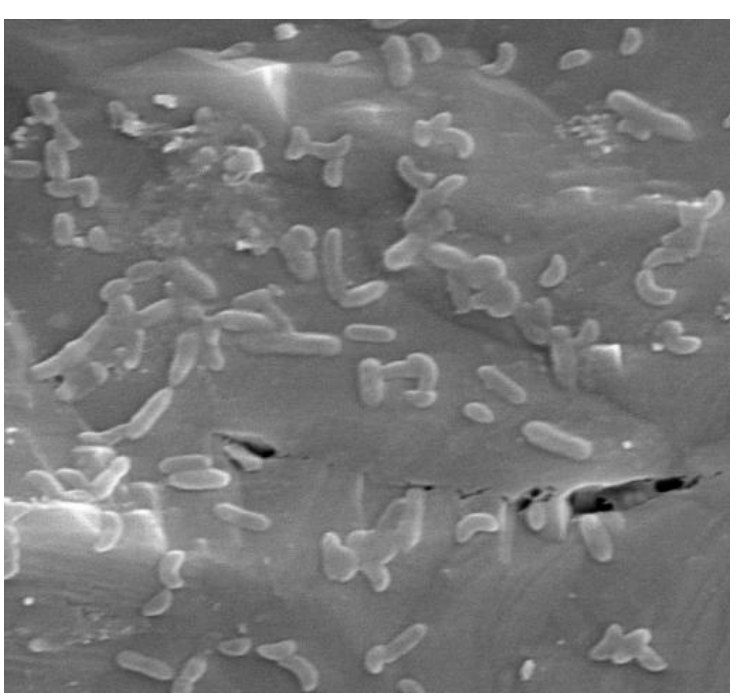

(a)

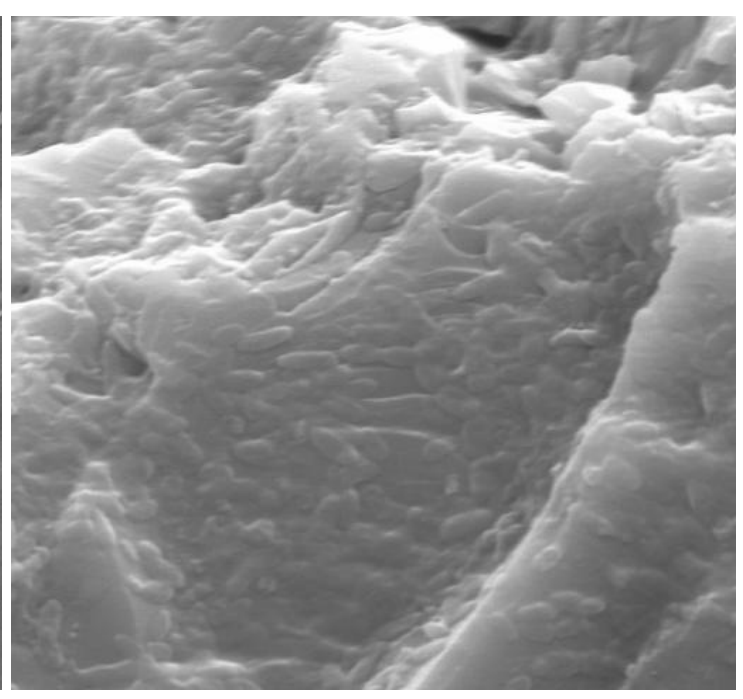

(b)

Figura 5.44: Microscopia eletrônica de varredura das morfologias observadas no reator em escala de bancada ao final da operação: (a) bacilos (b) bacilos e exopolímero (aumento 5000X) 


\subsection{Caracterização filogenética do Domínio Bacteria}

\subsubsection{Reator em Menor Escala}

Para a amostra do reator preenchido com pérolas de vidro (R3) foram obtidos 53 clones. Desse total, 14 clones foram relacionados ao Filo Bacteroidetes, Classe Sphingobacteria, Ordem Sphingobacteriales, mais especificamente aos seguintes gêneros: Niastella sp., Terrimonas sp., além de bactérias não cultivadas.

Outros 19 clones foram relacionados ao Filo Proteobacteria, Classes Alphaproteobacteria e Betaproteobacteria e um deles à Classe Gammaproteobacteria, e seguintes Ordens: Caulobacterales, Rhizobiales, Rhodospirillales, Sphingomonadales, Burkholderiales, Rhodocyclales e Xanthomonadales mais especificamente semelhantes a: Brevundimonas sp., Methylocella sp., Mesorhizobium sp., Acidisphaera sp., Novosphingobium sp., Brachymonas sp., Delftia sp., Aquabacterium sp., Zoogloea sp., Stenotrophomonas sp. e bactérias não cultivadas.

Dois clones foram relacionados ao Filo Actinobacteria, Classe Actinobacteria, Ordem Actinomycatales, especificamente a Mycobacterium sp., e Rhodococcus sp.

Três clones foram relacionados ao Filo Firmicutes. Desses clones, dois foram relacionados à Classe Clostridia, Ordem Clostridiales, semelhante a Clostridium sp. Outro clone foi relacionado à Classe Bacilli, Ordem Lactobacillales, especificamente semelhante a Trichococcus sp.

Entre os 15 clones restantes, quatro deles foram relacionados a Meiothermus sp., Gemmatimonas sp., Nitrospira sp. e Opitutus, sp. Onze clones foram relacionados a bactérias não classificadas.

Para a amostra do reator preenchido com areia (R4) foram obtidos 59 clones. Desse total, 15 clones foram relacionados ao Filo Bacteroidetes, Classe Sphingobacteria, Ordem Sphingobacteriales, mais especificamente semelhantes a: Niastella sp., Runella sp., Terrimonas sp. e bactérias não cultivadas.

Outros 15 clones foram relacionados ao Filo Proteobacteria, Classes Alphaproteobacteria, Betaproteobacteria e Gammaproteobacteria, Ordens Rhizobiales, Rhodospirillales, Sphingomonadales, Burkholderiales e Xanthomonadales mais especificamente semelhantes a Aminobacter sp., Rhizobium sp., Acidisphaera sp., 
Sandaracinobacter sp., Sphingopyxis sp., Acidovorax sp., Ramlibacter sp., Stenotrophomonas sp. e bactérias não cultivadas.

Sete clones foram relacionados ao Filo Actinobacteria, Classe Actinobacteria, Ordens Actinobacteridae e Actinomycatales, mais especificamente semelhantes a Mycobacteriaceae sp., Gordonia sp. e Rhodococcus sp.

Dois clones foram relacionados ao Filo Acidobacteria, Classe Acidobacteria, gêneros $G p 4$ sp. e $G p 6$ sp.

Três clones foram relacionados ao Filo Firmicutes. Um deles a Classe Clostridia, Ordem Clostridiales, semelhantes a Clostridium sp. e outros dois a Classe Bacilli, Ordem Lactobacillales, semelhantes a Trichococcus sp.

Sete clones foram relacionados ao Filo Deinococcus-Thermus, Classe Deinococci, Ordem Thermales, semelhantes a Meiothermus sp.

Um clone foi relacionado ao Filo Chloroflexi e dois clones foram semelhantes a Gemmatimonas sp. e Nitrospira sp.

Os sete clones restantes foram identificados como bactérias não classificadas.

As FigurasFigura 5.45 e Figura 5.46 representam as porcentagens de clones de cada amostra de reator relacionados aos diferentes Filos e Classes, respectivamente.

Vale ressaltar que tal comparação, apesar de estar representada em porcentagem não representa quantitativamente, mas, qualitativamente os microrganismos presentes em cada reator.

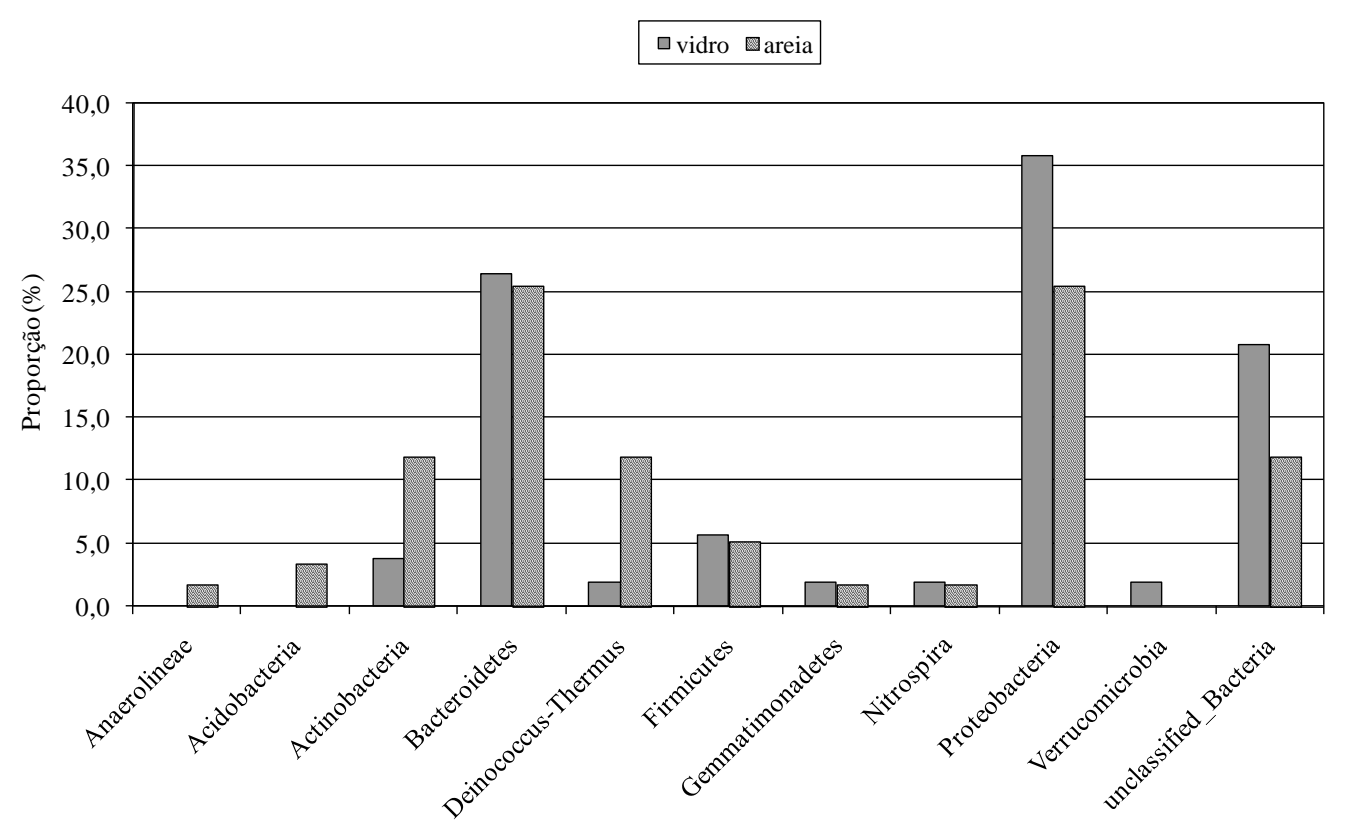

Figura 5.45: Porcentagem de clones dos reatores preenchido com pérolas de vidro (R3) e areia (R4) relacionados aos diferentes Filos 
Os clones presentes nos reator preenchido com pérolas de vidro (R3) foram semelhantes a oito diferentes Filos (Figura 5.45). A maior quantidade de clones (36\%) foi relacionada ao Filo Proteobacteria, seguido por Bacteroidetes (26\%). Os demais Filos se apresentaram em porcentagens inferiores a 5\%. Representantes do Filo Verrucomicrobia foram encontrados apenas neste reator (R3).

Da mesma maneira que em R3, os clones predominantes em R4 (areia) foram relacionados a Proteobacteria e Bacteroidetes (25\% cada). Do total de nove Filos presentes, apenas dois não foram encontrados em R3, Anaerolineae e Acidobacteria. Aparentemente os Filos Actinobacteria e Deinococcus-Thermus foram favorecidos no reator quando o material suporte utilizado foi areia (R4), enquanto que os Filos Firmicutes, Gemmatimonadetes e Nitrospira foram encontrados na mesma proporção que em R3 (pérolas de vidro).

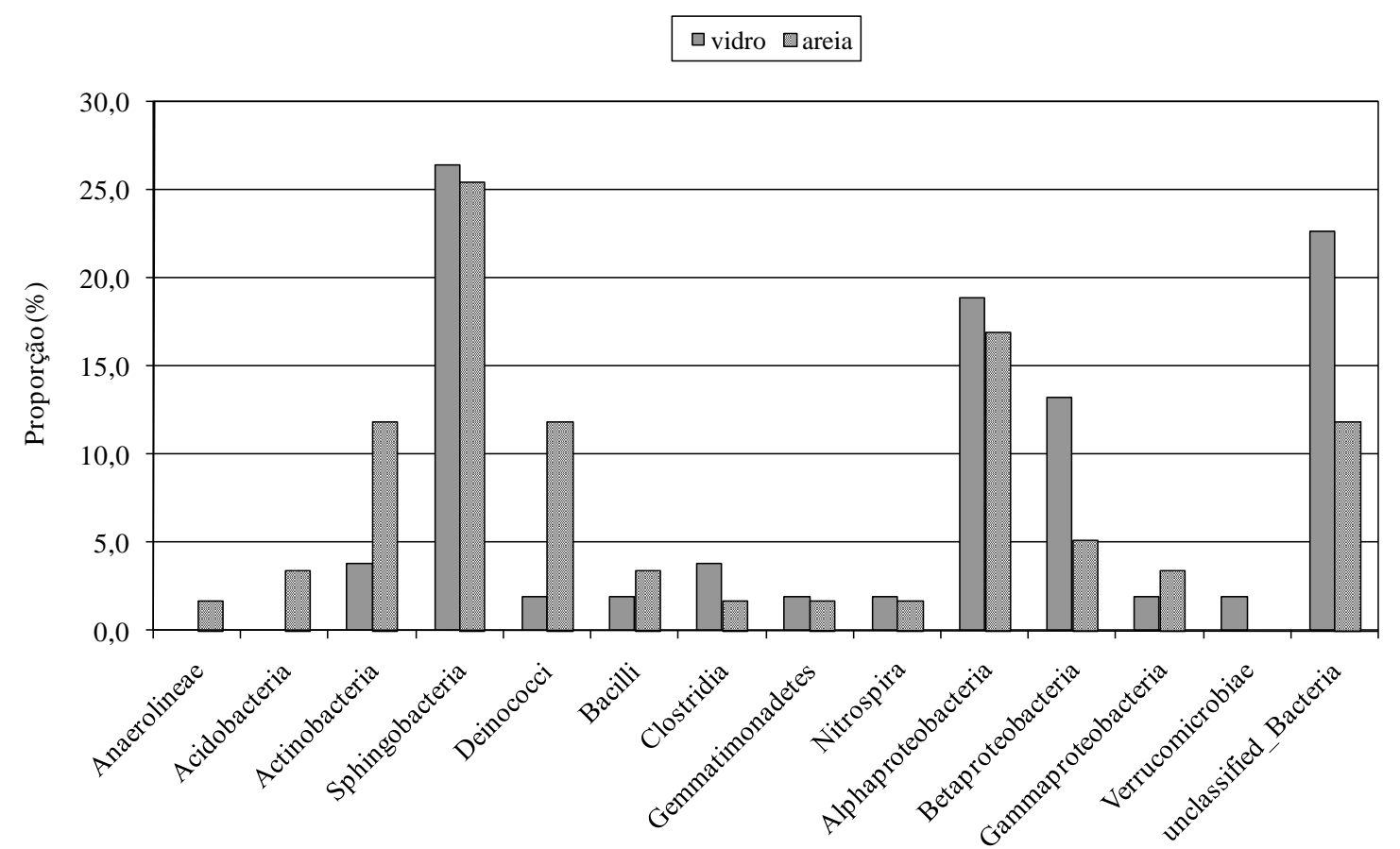

Figura 5.46: Porcentagem de clones dos reatores preenchido com pérolas de vidro (R3) e areia $(\mathrm{R} 4)$ relacionados às diferentes Classes

Maior número de filos foi encontrado em R4 (areia). Da mesma maneira, apresentou também maior quantidade de Classes quando comparado a R3 (pérolas de vidro). Foram encontradas 11 Classes em R3 e 12 Classes em R4 
Sphingobacteria foi a Classe predominante em R3 e R4 com mais de $25 \%$ dos clones, seguido por Alphaproteobacteria com valores de porcentagem entre $15 \%$ e $20 \%$ em ambos os reatores.

A Classe Betaproteobacteria foi encontrada em maior quantidade em R3 (14\%) do que em R4 (5\%), enquanto que Actinobacteria foi relacionada a mais de $10 \%$ dos clones presentes em R4 e menos de 5\% dos clones presentes em R3, assim como Deinococci.

As Classes Bacilli, Clostridia, Gemmatimonadetes, Nitrospira e Gammaproteobacteria foram relacionadas a menos que 5\% dos clones em ambos os reatores. Anaerolineae e Acidobacteria foram encontradas apenas em R4 (areia), enquanto que Verrucomicrobiae foi encontrada apenas em R3 (pérolas de vidro). Essas três últimas classes citadas foram também relacionadas a menos de $5 \%$ dos clones obtidos em cada reator.

Pode-se observar que microrganismos pertencentes aos Filos Anaerolineae e Acidobacteria foram encontrados somente no reator preenchido com areia (R4), enquanto, no reator preenchido com pérolas de vidro (R3) foi encontrado microrganismo pertencente ao Filo Verrucomicrobia.

As bactérias pertencentes ao Filo Anaerolineae são estritamente anaeróbias, crescem numa faixa de temperatura entre $20^{\circ} \mathrm{C}$ e $50{ }^{\circ} \mathrm{C}, \mathrm{pH} 7$ como ótimo de crescimento e necessitam de extrato de levedura para crescerem (YAMADA et al., 2006). São bactérias filamentosas e, frequentemente, observadas na superfície de grânulos de tratamento de águas residuárias contendo carboidratos. Quatro cepas filamentosas de Anaerolineae foram isoladas de grânulos de reator UASB mesofílico e termofílico e caracterizadas em detalhes confirmando sua habilidade em fermentar carboidratos (YAMADA et al., 2008). A composição nutricional do reator do presente trabalho favoreceu o crescimento de tais células, uma vez que havia disponibilidade de carboidratos do extrato de levedura.

O Filo Acidobacteria é constituído por microrganismos acidofílicos e foram reconhecidas como uma nova divisão em 1997. Como a grande maioria dessas bactérias está classificada entre as não cultivadas, sua ecologia e metabolismo não estão bem conhecidos. No entanto, devem ser muito importantes para os ecossistemas, uma vez que são particularmente abundantes no solo (KUSKE et al., 1997). Possivelmente tais bacterias estavam presentes no lodo anaeróbio usado como inóculo nos reatores e 
encontraram ambiente mais favorável para se manter quando o suporte utilizado foi areia.

Estima-se que o Filo Verrucomicrobia inclua até $10 \%$ do total de bactérias no solo e contribua com até $9,8 \%$ do 16S RNAr bacteriano neste sistema (WAGNER e HORN, 2006). Membros do Filo Verrucomicrobia foram encontrados em pântanos e, seu aparecimento tardio após inundação, sugeriu que se adaptaram a baixas concentrações de substrato (NOLL et al., 2005). Sequências de 16S RNAr relacionadas à Verrucomicrobia foram também obtidas de sistemas aquáticos, incluindo água potável, lago, sedimentos marinhos e fontes termais (WAGNER e HORN, 2006). Além disso, sua presença é freqüente em aterro sanitário e em vários sistemas de tratamento. (CHOUARI et al., 2005). Sua presença neste trabalho justifica-se pelo inóculo inicial ser alimentado constantemente com substrato sintético. No entanto, apesar de ambos os reatores receberem a mesma alimentação, tal microrganismo foi encontrado apenas no reator preenchido com pérolas de vidro (R3) em apenas $2 \%$ dos clones. Essa quantidade indica que, possivelmente, o material suporte favoreceu a presença desse grupo que não seria encontrado nas condições de operação dos reatores.

Os demais Filos citados anteriormente foram representados em ambos os reatores em proporções ora semelhantes (Bacteroidetes - 25\%, Firmicutes - 5\%, Gemmatimonadetes - 2\%, Nitrospira - 2\%), ora diferentes (Actinobacteria - 4\% em R3 e $12 \%$ em R4, Deinococcus-Thermus - $2 \%$ em R3 e $12 \%$ em R4, Proteobacteria - 36\% em R3 e $26 \%$ em R4).

Nas pérolas de vidro (R3) foram constatados microrganismos pertencentes ao Filo Bacteroidetes semelhantes a Niastella sp. e Terrimonas sp. Esse último possui propriedades que permitem decompor células de plantas e de fungos aumentando a disponibilidade de carbono no solo para o metabolismo microbiano. A presença desses organismos no solo gera como resultado aumento nos elementos essenciais melhorando a fertilidade e crescimento de plantas (LESAULNIER et al., 2008). Os demais clones foram relacionados a bactérias encontradas em solos contaminados por níquel (HERRERA et al., 2007), aderidas a membranas em estações de tratamento de água (CHON et al., trabalho não publicado), em biorreatores de membrana degradando estrogênio (JIN et al., trabalho não publicado), na comunidade microbiana de solos na Califórnia (CRUZ et al., trabalho não publicado), em solos (LESAULNIER et al., 2008), em rios (SUESCUN et al., trabalho não publicado). Sua presença nesse trabalho 
pode estar relacionada ao substrato sintético de fácil degradação que simulou esgoto sanitário.

Os clones pertencentes ao Filo Bacteroidetes obtidos com amostra do reator preenchido com areia (R4) foram relacionados a bactérias encontradas em rio (SUESCUN et al., trabalho não publicado), a bactéria degradadora de clorobenzeno (NESTLER, et al., 2007), bactérias de ambiente subterrâneo (CHAPON et al., trabalho não publicado), comunidade presente em sistemas de lodos ativados (OSAKA et al., 2008), sedimento de reservatório de água em Pequim (China) (QU e YUAN, 2008), comunidade bacteriana em poeira doméstica (PAKARINEN et al., 2008) e em membranas de biorreatores usados na degradação de estrogênio (JIN et al., trabalho não publicado).

As bactérias pertencentes ao Filo Proteobacteria, Classe Alphaproteobacteria apresentam como característica geral o fato de serem facultativas ou obrigatoriamente anaeróbias e heterotróficas. Já as Betaproteobacterias consistem em classe de bactérias aeróbias ou facultativas que são altamente versáteis em suas capacidades de degradação. Muitas delas são encontradas em amostras ambientais como em água residuária ou solo. Algumas Gammaproteobacterias são oxidadoras de metano e muitas delas estão em simbiose com outros animais (LEE et al., 2005).

Os clones obtidos do reator com pérolas de vidro (R3) foram similares a Proteobacteria e relacionados a microrganismos encontrados em solo de pastagem tropical (DIALLO et al., 2004), em poeira de ambientes fechados (RINTALA et al., 2008), em solo poluído com bifenil policlorado (NOGALES et al., 2001), em reatores biológicos de tratamento de águas residuárias de lavanderia, chuveiro, higiene oral e urina (SAKANO et al., 2002), no intestino de microartóprodes presentes no solo (HOFFMANN et al., 1998) e em coluna de decloração do tetracloroeteno (BEHRENS et al., 2008). O trabalho de Sakano et al. (2002) é o que mais se aproxima do substrato utilizado neste trabalho uma vez que conta com a presença de surfactantes, provavelmente entre eles, o LAS. Desse modo, justificando a presença de tais células.

O Filo Proteobacteria representou 26\% dos clones de amostra do reator R4 (areia) e estiveram relacionados a bactérias encontradas em célula combustível (PHUNG et al., 2004), no intestino de abelhas (MOHR e TEBBE, 2006), em poeira de ambientes fechados (RINTALA, et al., 2008), em processos de biorremediação de solo contaminado com hidrocarboneto (MILITON et al., trabalho não publicado), em amostras de solo submetidas a diferentes condições de meio nutricional, inóculo e 
tempo de incubação (DAVIS et al., 2005), em solo sem vegetação (NEMERGUT et al., 2007) e na pele humana (GRICE et al., 2008). Sabendo que o LAS é derivado de hidrocarbonetos, a presença desses microrganismos no reator está relacionada ao trabalho de solo contaminado com hidrocarbonetos (MILITON et al., trabalho não publicado).

Representantes do filo Actinobacteria foram observados nos reators com pérolas de vidro (R3) e areia (R4). Os organismos do Filo Actinobacteria incluem alguns dos mais comuns que vivem no solo, e desempenham papel importante na decomposição da matéria orgânica e, consequentemente, no ciclo do carbono. Outros habitam plantas e animais, incluindo alguns agentes patogênicos como Mycobacterium e Rhodococcus. A maioria é anaeróbia, mas alguns deles podem crescer em condições aeróbias (CHILIMA et al., 2006)

Mycobacterium inclui muitas espécies que são comumente encontradas no ambiente (solo e água ou associado com plantas e animais), assim como espécies que são responsáveis por duas grandes doenças humanas, tuberculose (Mycobacterium tuberculosis) e lepra (Mycobacterium leprae) (CHILIMA et al., 2006).

Rhodococcus equi, principal agente da rodococose, é um cocobacilo pleomórfico, gram-positivo, aeróbio, parcialmente acidorresistente, não formador de endósporo, imóvel, amplamente distribuído na natureza (SEVERO et al., 2001).

Os dois gêneros citados anteriormente estiveram presentes em ambos os reatores, e, apesar de não estar diretamente ligados a degradação de compostos orgânicos, faziam parte da ampla diversidade presente no inóculo oriundo de lodo de reator UASB tratando dejetos de suinocultura.

As bactérias pertencentes ao filo Firmicutes, classe Clostridia, ordem Clostridiales foram relacionadas a Clostridium e observados nos dois reatores As bactérias deste gênero são Gram positivas, formadoras de endósporos, com ou sem mobilidade celular e comumente encontrada no solo, lodos anaeróbios, sedimentos marinhos, fezes de animais, trato intestinal de humanos e outros vertebrados. Realizam metabolismo desassimilativo de redução de sulfato, além de produzirem ácidos orgânicos e álcoois a partir de carboidratos ou peptona (BERGEY, 1986).

Os clones sequenciados no presente trabalho foram relacionados a Clostridium sp. A composição nutricional dos reatores favoreceu o crescimento de tais células, uma vez que havia disponibilidade de carboidratos e aminoácidos (extrato de levedura) e sulfato proveniente da oxidação do sulfito liberado no rompimento do anel aromático da 
molécula de LAS. Denger et al. (1996) isolaram Clostridium sp. EV4SPB em meio nutricional contendo [2-(4-sulfofenil) butirato] e Clostridium sp. EV4 na presença de fenil sulfonado, p-benzeno-sulfonado e naftaleno-2,6-dissulfonado. Segundo os autores, as células isoladas foram capazes de utilizar todos esses compostos.

$\mathrm{Na}$ areia, as bactérias relacionadas ao Filo Firmicutes foram semelhantes aquelas encontradas em trabalhos com culturas de bactérias desnitrificantes (HEYLEN et al., 2006) e em população microbiana de fezes suínas e em fossa de armazenamento de estrume (WHITEHEAD e COTTA, trabalho não publicado). Sua presença no reator é justificada em função do inóculo utilizado para operação dos reatores, uma vez que foi proveniente de lodo de reator UASB usado no tratamento de dejetos de suinocultura.

Dos clones encontrados em ambos os reatores relacionados ao Filo Nitrospira, especificamente a Nitrospira sp., um deles, presente em R4 (areia) foi semelhante a bactéria de biorreator operado em bateladas seqüenciais e alimentado com solução de sais e nitrito (BURRELL et al., 1998). No presente trabalho não havia fonte de nitrito na alimentação, porém havia solução de sais semelhante a usada no trabalho relacionado.

Bactérias encontradas em amostras de água de chuveiro (PACE trabalho não publicado), em lodo de esgoto sanitário (DRZYZGA et al., 2008) e em solo contaminado com tóxicos (NGUYEN, et al., trabalho não publicado) foram relacionadas aos clones do Filo Actinobacteria encontrados no reator R4 (areia). Tais semelhanças já eram esperadas uma vez que o reator foi alimentado com surfactante (semelhante a água de chuveiro e tóxico) e substrato sintético que simula esgoto sanitário. No entanto, tais relações foram apenas obtidas no reator preenchido com areia. Possivelmente o material suporte favoreceu sua presença quando comparado com as pérolas de vidro.

O Filo Deinococcus-Thermus encontrado em ambos os reatores, porém em maior porcentagem em R4 (areia) é formado por um pequeno grupo de bactérias composto por cocos altamente resistentes. Existem duas ordens principais. Uma delas é o Deinococcales, que possui um único gênero, Deinococcus, com várias espécies que são resistentes à radiação e possuem habilidades para degradar resíduos nucleares e outros compostos tóxicos e sobreviver em condições extremas de calor e frio. Outra ordem deste Filo são os Thermales, que incluem vários gêneros resistentes ao calor (MARGULIS e SCHWARTZ, 1998). Os clones pertencentes a este Filo foram relacionados a bactérias encontradas em águas subterrâneas de mina de ouro (LIN, et al., 2006) e em solo poluído com cromo (DESAI, et al., 2009) mostrando sua resistência a condições adversas. 
O Filo Gemmatimonadetes foi representado por $2 \%$ dos clones obtidos em cada um dos reatores. As bactérias pertencentes a esse filo foram assim classificadas em 2003 por Zhang e colaboradores que a isolaram de um reator anaeróbio-aeróbio operado em bateladas sequenciais de remoção de fósforo para tratamento de água residuária. São aeróbias na forma de bacilos Gram-negativos. Crescem a temperatura ótima de $30{ }^{\circ} \mathrm{C}$ e pH 7,0. São capazes de utilizar alguns substratos como extrato de levedura, acetato e benzoato. Sua presença nos reatores pode ter ocorrido próximo as mangueiras de alimentação, recirculação e pontos de coleta de amostras, uma vez que existe a possibilidade de passagem de oxigênio do ar pela mangueria de silicone. No entanto, vale ressaltar que dentre os 53 clones obtidos para R3 e 59 para R4, apenas um em cada reator foi relacionado ao filo Gemmatimonadetes e foram semelhantes a bactérias encontradas em sedimento de rio de água doce (HORNER-DEVINE et al., 2003).

Mesmo apresentando similaridade com algumas bactérias cultivadas, grande parte dos clones presentes em ambos os reatores foi relacionada com bactérias não cultivadas. Segundo a descrição do GenBank, foram relacionadas com bactérias de células combustíveis (dispositivo eletroquímico que converte energia química em energia elétrica usando a ação catalítica de microrganismos ativos eletroquimicamente) (KIM et al., 2006), amostras de água de chuveiro (PACE, trabalho não publicado), sedimentos de rios (BANIULYTE et al., 2009), efluente de tanque séptico (TOMARAS et al., trabalho não publicado), em biofilme de estação de tratamento de água recebendo cloro residual (WILLIAMS et al., trabalho não publicado). As similaridades com células não cultiváveis podem ser justificadas, pois os reatores foram inoculados com lodo proveniente de reator UASB usado no tratamento de dejetos de suinocultura.

Outros clones relacionados com bactérias não cultivadas foram semelhantes a microrganismos presentes no solo de plantação de arroz (RUI et al., trabalho não publicado), biofilme de rocha de mina de ouro (TOMCZYZ-ZAK trabalho não publicado), e amostras ambientais (YU et al., trabalho não publicado).

Duarte et al. (2009) realizaram análise filogenética de amostra de reator anaeróbio horizontal de leito fixo (RAHLF) preenchido com espuma de poliuretano como material suporte e lodo de reator UASB usado no tratamento de dejetos de suinocultura como inóculo. Tal reator foi usado para degradação de $14 \mathrm{mg} / \mathrm{L}$ de LAS presente em substrato sintético semelhante ao do presente trabalho. No trabalho citado foram encontrados clones relacionados ao Filo Firmicutes, mais especificamente à classe Clostridia, ordem Clostridiales e Filo Proteobacteria, classe Alfaproteobacteria, 
deltaproteobacteria e Betaproteobacteria, além de bactérias não cultivadas, sendo a maioria dos clones relacionada com Clostridium sp.

No caso do reator horizontal de leito fixo, encontrou-se menor número de filos quando comparado a amostras do reator de leito fluidificado inoculado com mesmo lodo, sugerindo maior diversidade microbiana no segundo reator. Provavelmente, a configuração do reator influenciou na seleção dos microrganismos pelo fato do primeiro ser de fluxo pistonado e o segundo de mistura completa. No entanto, vale ressaltar que Duarte (2006) obteve apenas 34\% de degradação do surfactante em 313 dias de operação do reator. Todavia, no reator de leito fluidificado foram obtidos $93 \%$ de remoção após 270 dias de operação. Portanto, essa elevada eficiência de remoção foi obtida devido às características hidrodinâmicas do sistema reacional, as quais favoreceram maior diversidade de microrganismos responsáveis pela degradação do LAS. Deve-se destacar também a importância dos materiais suporte e co-substrato, nesse caso, sacarose, além do extrato de levedura, como fonte de nitrogênio e aminoácidos hidrolisados; fundamentais para a manutenção dessa comunidade diversa de microrganismos, os quais estavam aptos a degradação do surfactante.

Para a construção da árvore filogenética, as sequências foram agrupadas em unidades taxonômicas operacionais (UTO), com mais de 97\% de similaridade. Assim, algumas UTOs foram constituídas de um único clone, enquanto outras foram formadas por mais de um clone. As Tabelas Tabela 5.15 e Tabela 5.16 apresentam os clones classificados em UTOs dos reatores R3 e R4, respectivamente.

Tabela 5.15: Clones do reator R3 (pérolas de vidro) classificados em Unidades Taxonômicas Operacionais (UTOs)

\begin{tabular}{clcccc}
\hline UTO & \multicolumn{1}{c}{ Clones } & UTO & Clones & UTO & Clones \\
\hline 01 & V23, V24, V25 & 13 & V03 & 23 & V13 \\
02 & V26, V27, V28 & 14 & V04 & 24 & V14 \\
03 & V29, V30 & 15 & V05 & 25 & V15 \\
04 & V31, V32 & 16 & V06 & 26 & V16 \\
05 & V33, V34 & 17 & V07 & 27 & V17 \\
06 & V35, V36 & 18 & V08 & 28 & V18 \\
09 & V37, V38 & 18 & V09 & 29 & V19 \\
10 & V38, V40 & 20 & V10 & 30 & V20 \\
11 & V01 & 21 & V11 & 31 & V21 \\
12 & V02 & 22 & V12 & 32 & V22 \\
\hline
\end{tabular}


Tabela 5.16: Clones do reator R4 (areia) classificados em Unidades Taxonômicas Operacionais (UTOs)

\begin{tabular}{clcccc}
\hline UTO & \multicolumn{1}{c}{ Clones } & UTO & Clones & UTO & Clones \\
\hline 01 & A35, A36, A37, A38 & 16 & A10 & 31 & A20 \\
02 & A24, A33, A38, A50 & 17 & A04 & 32 & A33 \\
03 & A43, A44, A45 & 18 & A01 & 33 & A26 \\
04 & A46, A47 & 18 & A15 & 34 & A27 \\
05 & A48, A49 & 20 & A14 & 35 & A25 \\
06 & A50, A51 & 21 & A11 & 36 & A22 \\
07 & A52, A53 & 22 & A03 & 37 & A28 \\
08 & A54, A55 & 23 & A02 & 38 & A24 \\
09 & A56, A57 & 24 & A07 & 39 & A23 \\
10 & A58, A59 & 25 & A05 & 40 & A30 \\
11 & A13 & 26 & A16 & 41 & A34 \\
12 & A18 & 27 & A17 & 42 & A31 \\
13 & A06 & 28 & A09 & 43 & A29 \\
14 & A12 & 29 & A19 & 44 & A21 \\
15 & A08 & 30 & A32 & & \\
\hline
\end{tabular}

No caso de R3 (pérolas de vidro) apenas 39 clones foram utilizados na construção da árvore. Já os clones obtidos da amostra de R4 (areia) foram divididos em duas árvores filogenéticas. Isso ocorreu porque os primers usados no sequenciamento não se anelaram a região de homologia de maneira uniforme para todos os clones. Assim, quando todos os clones foram alinhados não foi possível encontrar uma região de tamanho adequado para a análise filogenética que fosse comum a todos.

Os clones presentes na árvore filogenética do reator R3 (pérolas de vidro) foram relacionados em $67 \%$ a $100 \%$ de similaridade aos grupos encontrados. Tais valores estão apresentados na Tabela 5.17 bem como as unidades taxonômicas operacionais (UTOs), número de acesso no NCBI e a sua descrição.

Os clones presentes na árvore filogenética do reator R4 (areia) foram relacionados em $42 \%$ a $100 \%$ de similaridade aos grupos encontrados. Tais valores estão apresentados na Tabela 5.18 bem como as unidades taxonômicas operacionais (UTOs), número de acesso no NCBI e a sua descrição.

As Figuras Figura 5.47 a Figura 5.49 apresentam as árvores filogenéticas construídas com os clones relacionados às Classes mencionadas anteriormente. 


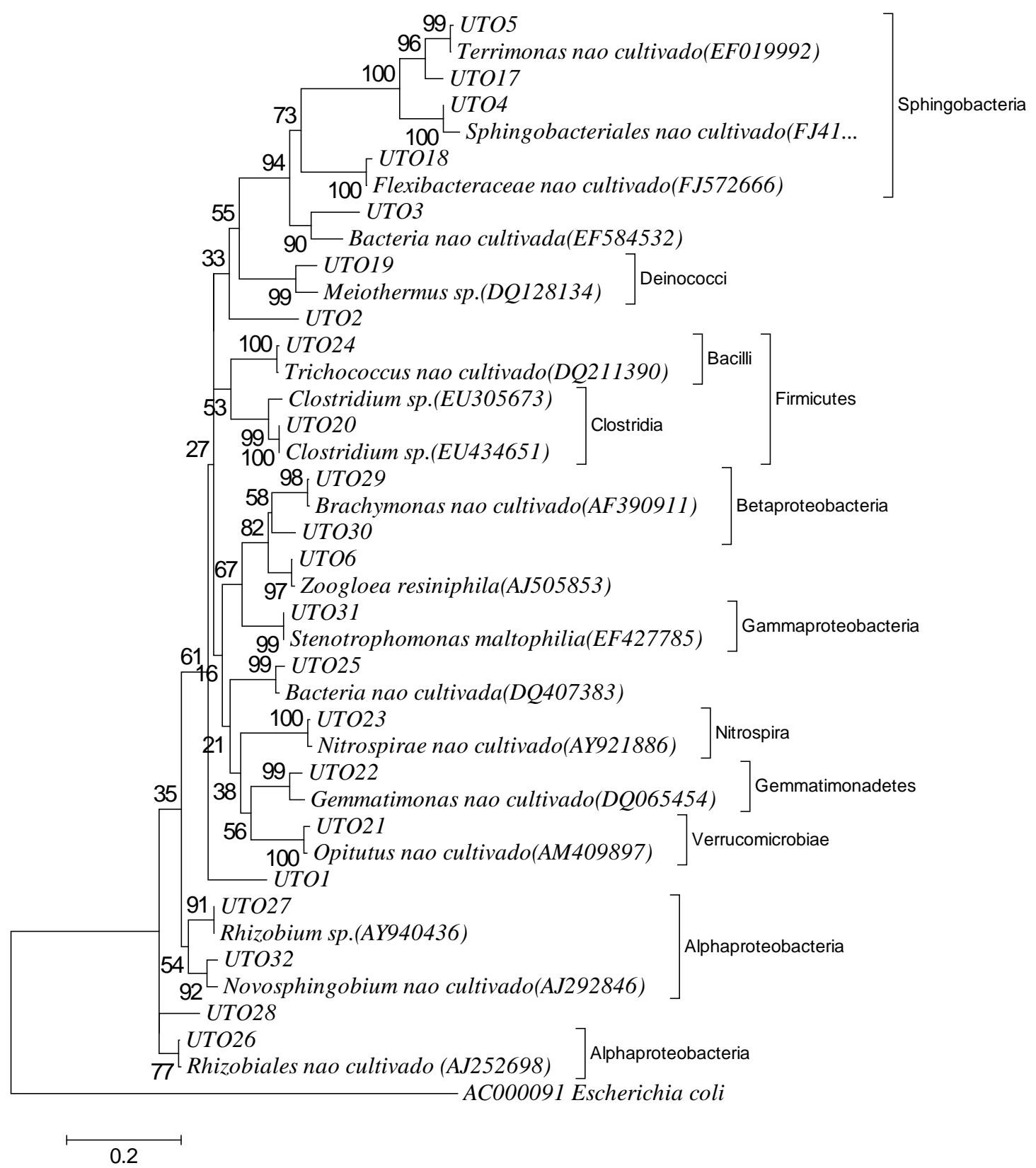

Figura 5.47: Árvore filogenética do reator R3 (pérolas de vidro) mostrando a posição dos clones derivados das sequências do RNAr 16S. Eschericha coli foi usada como grupo externo. A taxa de substituição a cada 100 nucleotídeos foi de 0,2 como indicado na barra de escala. 


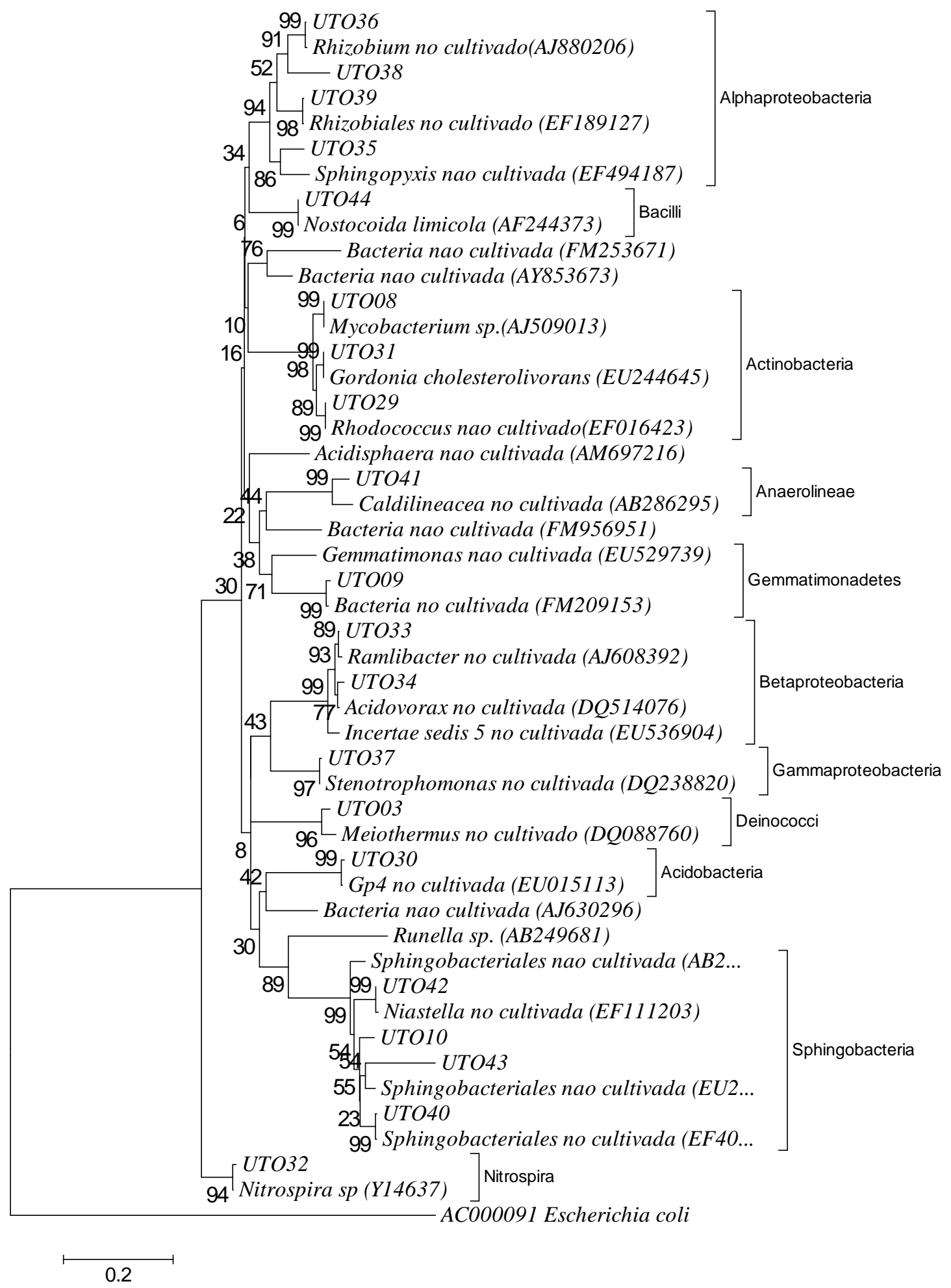

Figura 5.48: Árvore filogenética 1 do reator R4 (areia) mostrando a posição dos clones derivados das sequências do RNAr 16S. Eschericha coli foi usada como grupo externo. A taxa de substituição a cada 100 nucleotídeos foi de 0,2 como indicado na barra de escala. 


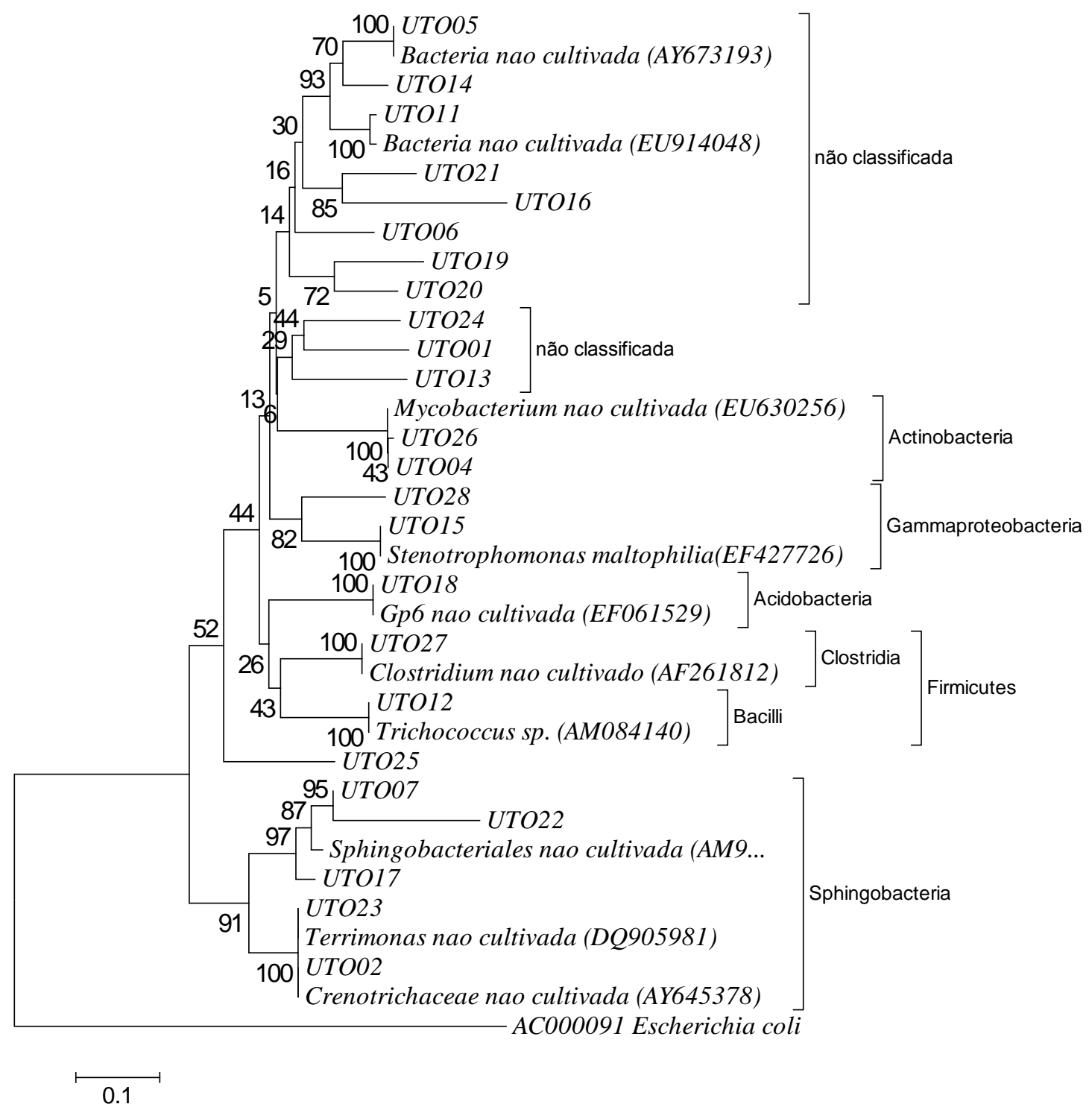

Figura 5.49: Árvore filogenética 2 do reator R4 (areia) mostrando a posição dos clones derivados das sequências do RNAr 16S. Eschericha coli foi usada como grupo externo. A taxa de substituição a cada 100 nucleotídeos foi de 0,1 como indicado na barra de escala. 
Tabela 5.17: Sequências obtidas no Genbank relacionadas aos clones da amostra do reator R3 (pérolas de vidro)

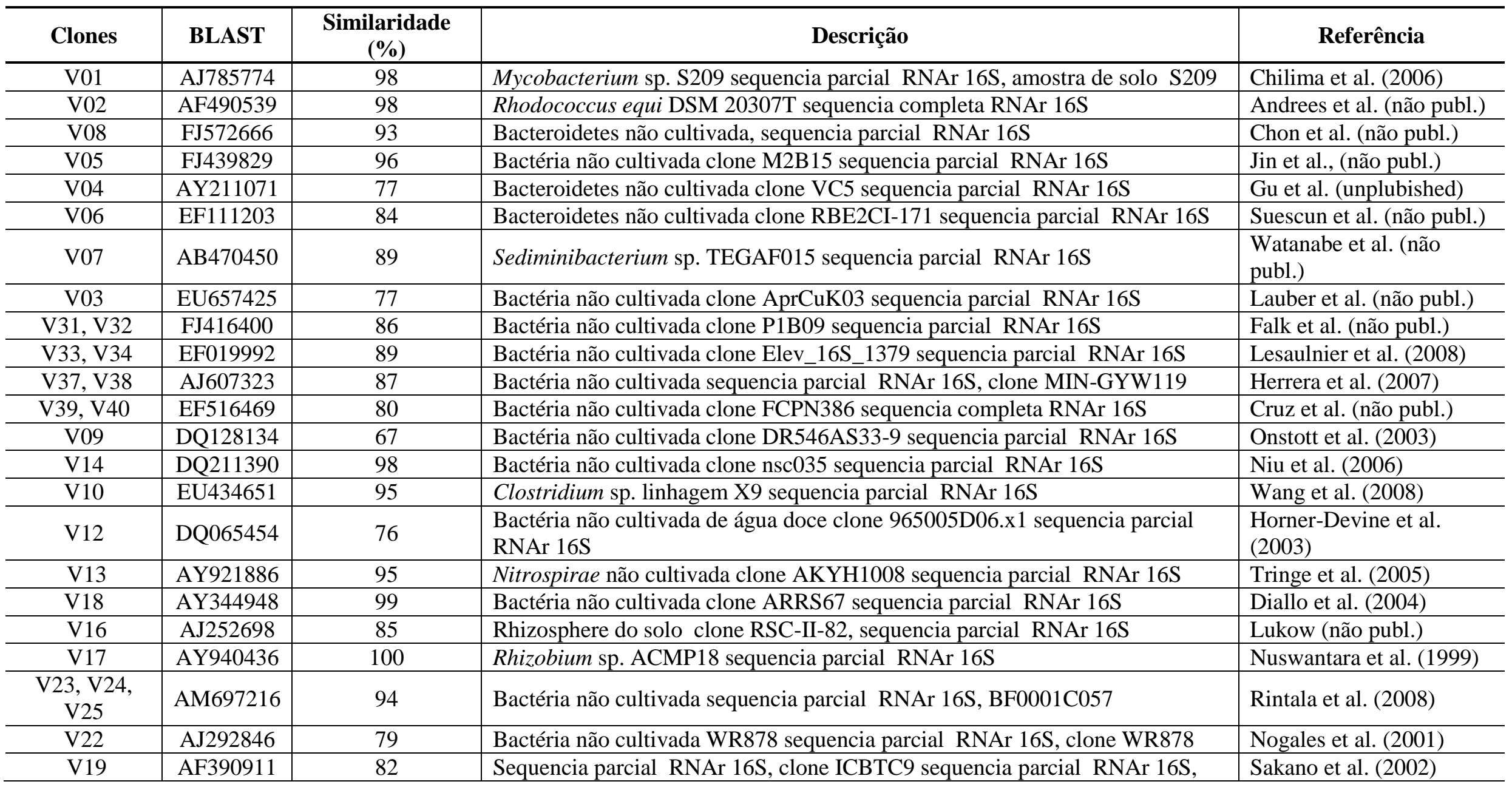


Tabela 5.17 (cont.): Sequências obtidas no Genbank relacionadas aos clones da amostra do reator R3 (pérolas de vidro)

\begin{tabular}{c|c|c|l|l}
\hline Clones & BLAST & Similaridade & \multicolumn{1}{c}{ Descrição } \\
\hline V20 & EF463078 & 99 & Alicycliphilus sp. BQ8 sequencia parcial RNAr 16S, \\
\hline V35, V36 & FM178532 & 96 & $\begin{array}{l}\text { Sequencia parcial RNAr 16S, sequencia parcial RNAr 16S, } \\
\text { clone473_A23_PCE_coluna_inflow. }\end{array}$ \\
\hline V21 & EF427785 & 99 & Stenotrophomonas maltophilia linhagem H597 sequencia parcial RNAr 16S, & Pimentel et al (2007) \\
\hline V11 & AM409897 & 81 & Bactéria não cultivada, sequencia parcial RNAr 16S, clone d1-18 \\
\hline V15 & DQ407383 & 78 & $\begin{array}{l}\text { Bactéria não cultivada clone tpb-16-IJ-C05 subunidade menor do RNAr 16S } \\
\text { sequiencial parcial }\end{array}$ & Schwarz et al. (não publ.) \\
\hline V26, V27, V28 & EU262307 & 78 & Bactéria não cultivada clone 2005-MA-3-061907 sequencia parcial RNAr 16S, & Baniulyte et al. (2009) \\
\hline V29, V30 & AJ630296 & 87 & $\begin{array}{l}\text { Cytophagales/sulfobactéria verde não identificada OPB56 sequencia parcial } \\
\text { RNAr 16S, clone MFC-EB28 }\end{array}$ & Kim et al. (2006) \\
\hline
\end{tabular}


Tabela 5.18: Sequências obtidas no Genbank relacionadas aos clones da amostra do reator R4 (areia)

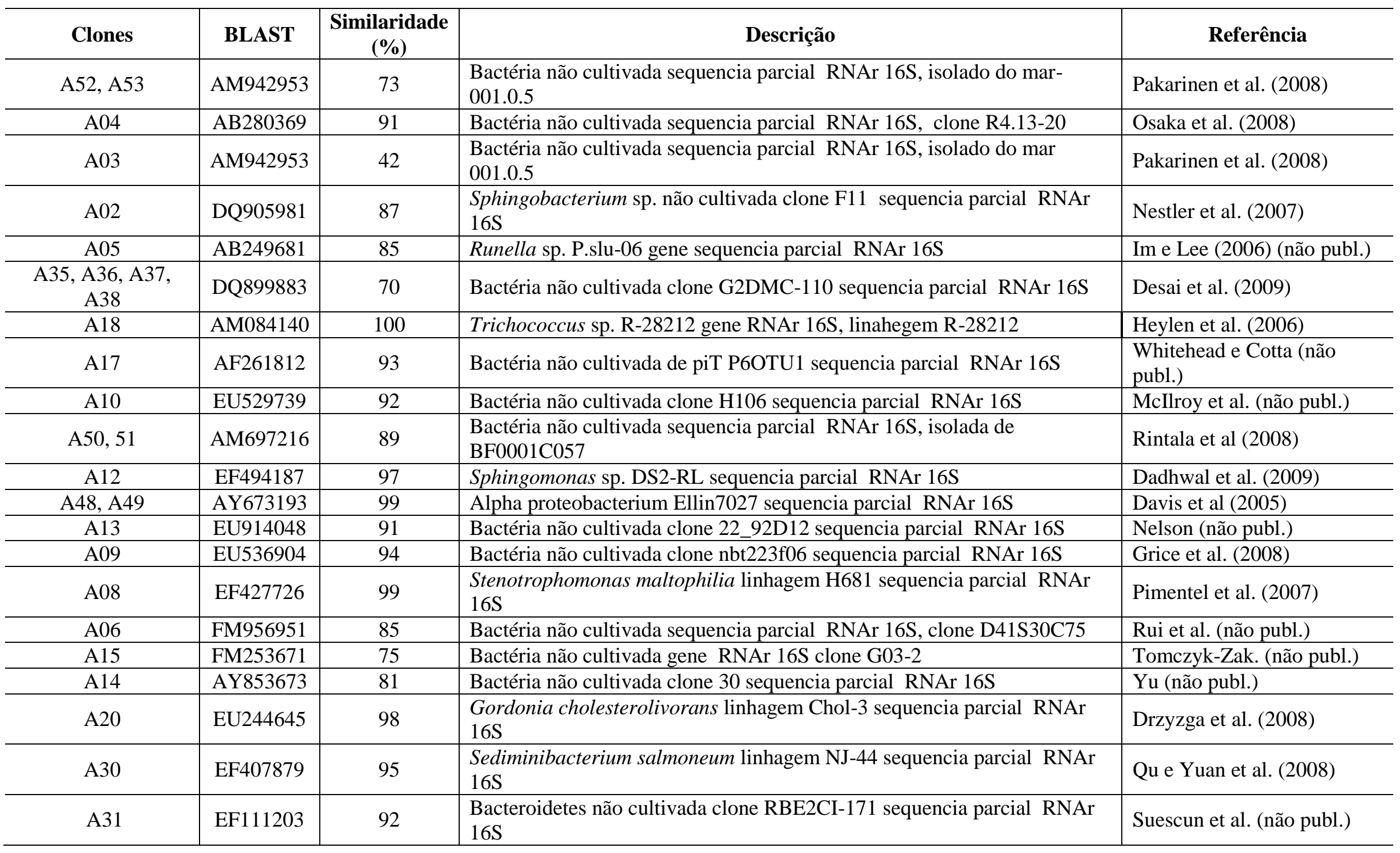


Tabela 5.18 (cont.): Sequências obtidas no Genbank relacionadas aos clones da amostra do reator R4 (areia)

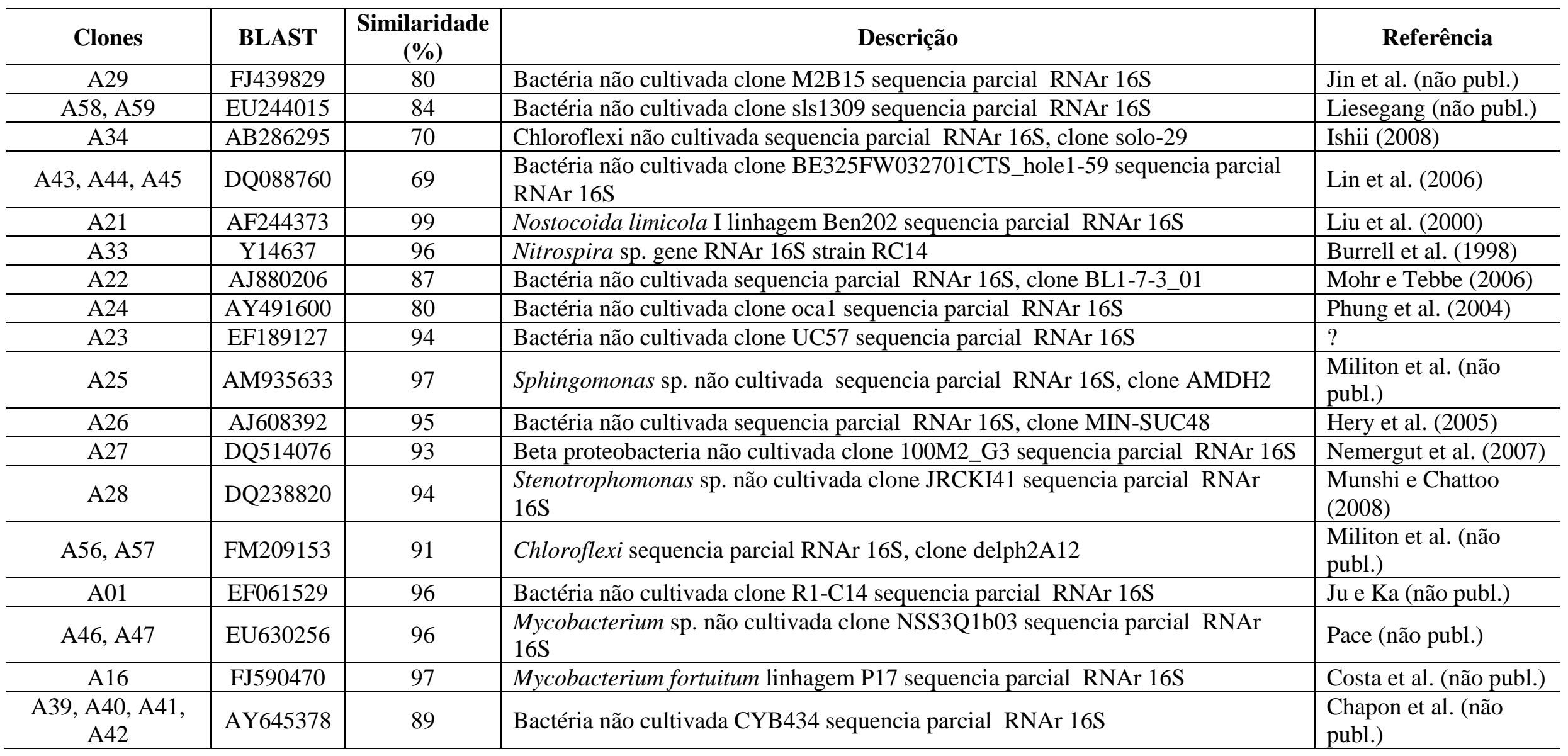




\subsubsection{Reator em Escala de Bancada}

Para a amostra do reator em escala de bancada operado por 270 dias com concentrações crescentes de LAS e preenchido com areia como material suporte foram obtidos 105 clones. Desse total, 46 clones foram relacionados ao Filo Proteobacteria (Classes Alpha-, Beta-, Gamma- e Delta-proteobacteria), 44 a Bacteroidetes (Classes Sphingobacteria e Flavobacteria), 4 a Verrucomicrobia (Classe Verrucomicrobiae), 3 a Acidobacteria (Classe Acidobacteriae), 2 a Firmicutes (Classe Clostridia), 1 a Gemmatimonadetes (Classe Gemmatimonadetes) e 5 a Bactérias não classificadas. Acredita-se a diferença encontrada em relação aos reatores menores seja devido ao maior tempo de operação e concentrações maiores do surfactante.

As FigurasFigura 5.50 eFigura 5.51 apresentam os Filos e Classes relacionados aos clones obtidos em termos de porcentagem.

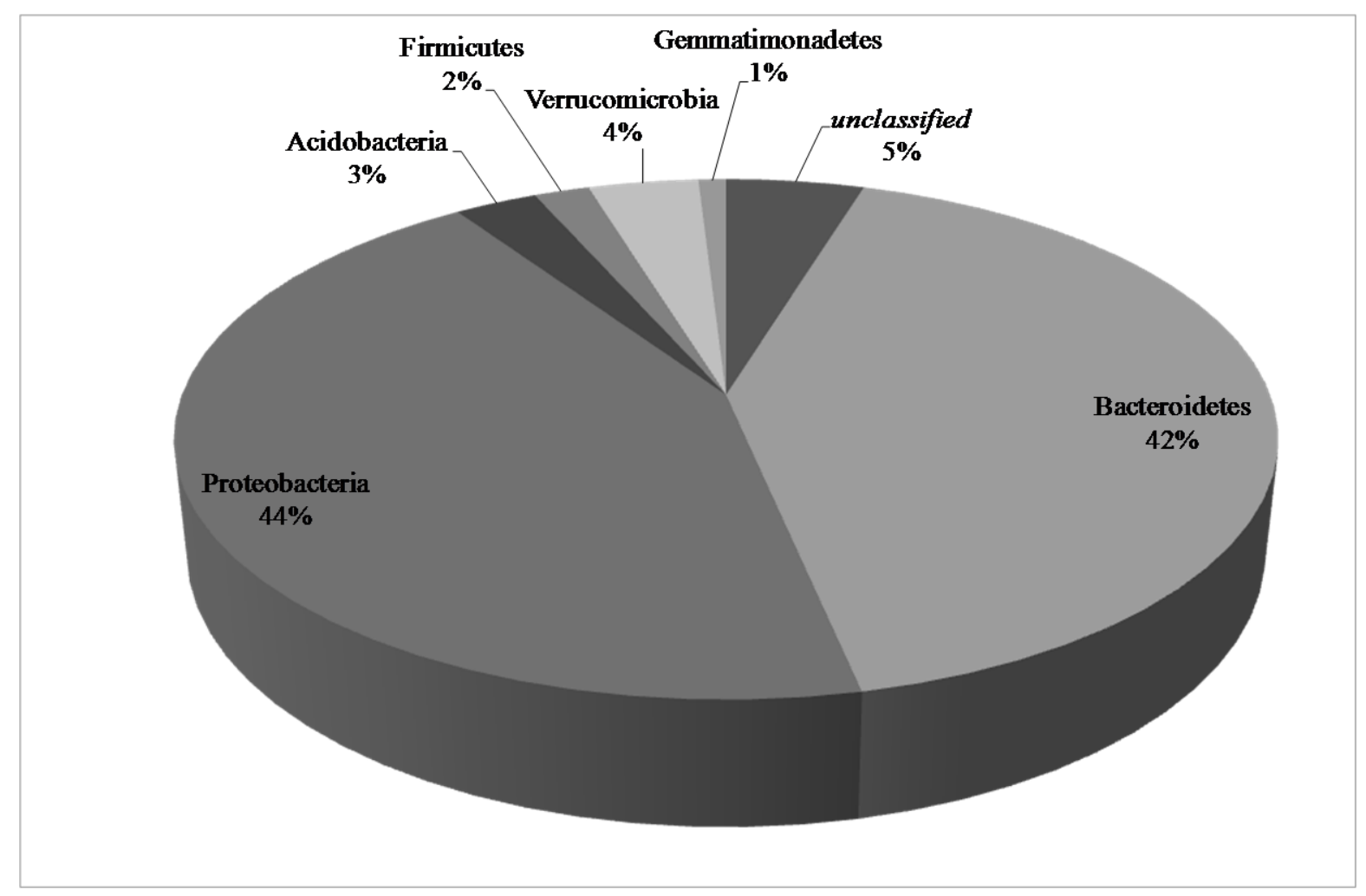

Figura 5.50: Porcentagem de clones relacionada aos diferentes Filos 


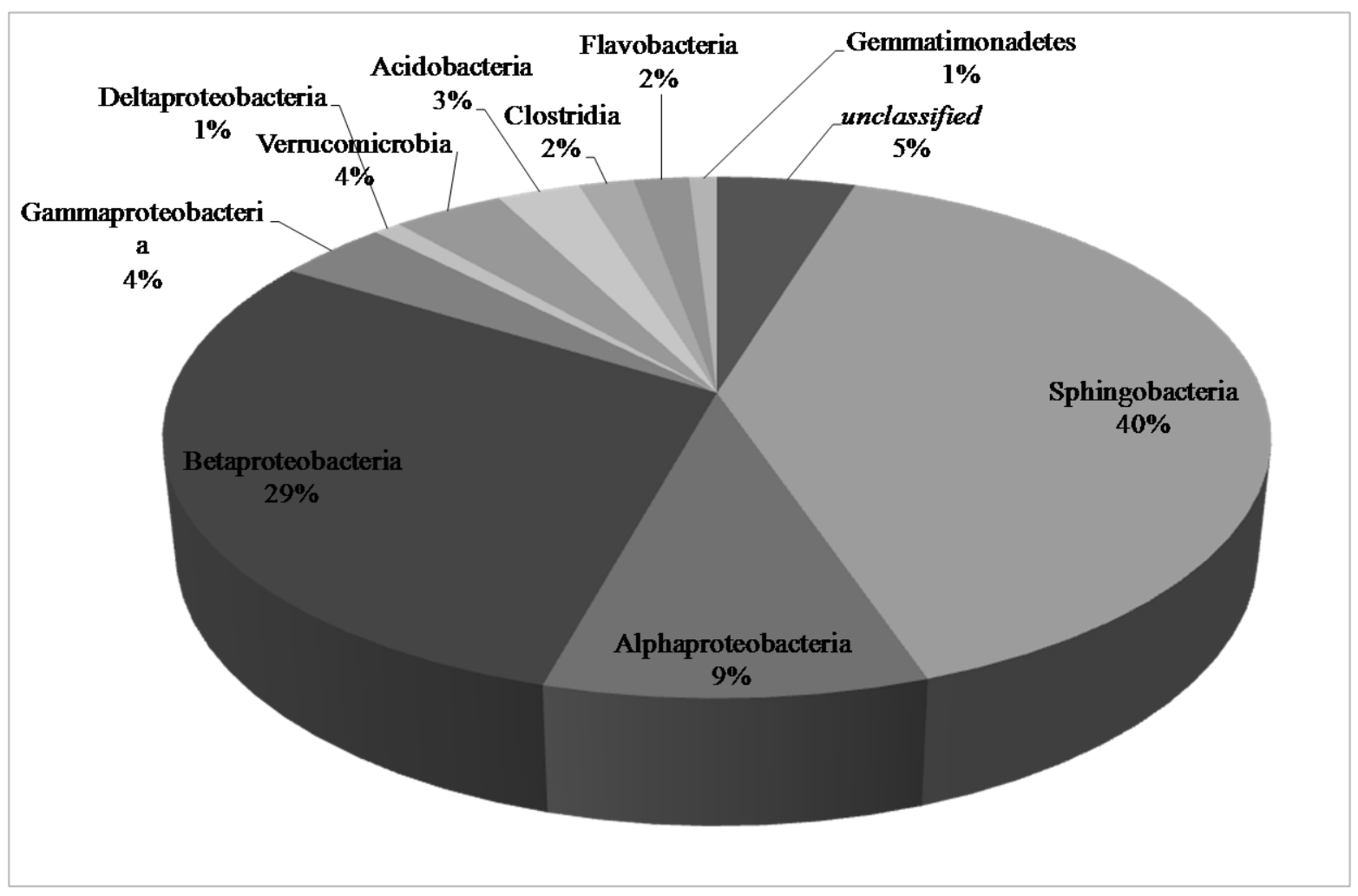

Figura 5.51: Porcentagem de clones relacionada às diferentes Classes

Quanto a quantidade de Filos e Classes, pode se constatar menor diversidade quando comparadas aos reatores em menor escala.

Algumas Classes mantiveram presentes (Acidobacteria, Sphingobacteria, Clostridia, Gemmatimonadetes, Alpha, Beta e Gammaproteobacteria e Verrucomicrobiae), outras apareceram somente nos reatores em menor escala (Anaerolineae, Actinobacteria, Deinococci, Bacilli, Nitrospira) e outras duas foram encontradas somente no reator em escala de bancada (Deltaproteobacteria e Flavobacteria).

Como a quantidade de clones obtida no reator em escala de bancada foi maior, a menor diversidade pode estar relacionada com uma possível seleção dos microrganismos pela maior concentração do surfactante aliada ao maior tempo de operação do reator.

Como mencionado anteriormente, do total de 105 clones, 44 foram relacionados ao Filo Bacteroidetes, sendo 42 desse filo pertencentes a Classe Sphingobacteria, mais especificamente a Niastella sp., Terrimonas sp. e bactérias não cultivadas. Os outros 2 clones foram classificados como Classe Flavobacteria, gênero Cloacibacterium.

As bactérias pertencentes a Sphingobacterias são Gram negativas em forma de haste, não formadoras de endósporos, não têm flagelo mas podem exibir mobilidade deslizante e catalase positiva. Esses organismos são quimiorganotróficos sem necessidade de fator de 
crescimento especializado. Colônias geralmente tornam-se amareladas após vários dias a temperatura ambiente. Ácidos são produzidos oxidativamente de carboidratos, mas não fermentativamente (YABUUCHI et al., 1983). Niastela sp. e Terrimonas sp. também foram encontradas nos reatores em menor escala preenchidos com pérolas de vidro e areia.

Os demais clones obtidos no reator pertencentes à Classe Sphingobacteria foram relacionados a bactérias presentes em lodos ativados (BROWN E TURNER, trabalho não publicado), em resíduos de baixa carga (FIELD et al., trabalho não publicado), em sistema de abastecimento de água (EICHLER et al., 2006), em água de pântano (CHEN et al., trabalho não publicado), rios de clima temperado (CRUMO E HOBBIE, 2005), sedimento de mar recebendo descarga de agricultura (SINKKO et al., trabalho não publicado), solo em ecossistema de arbusto (LIPSON et al., 2005), membrana de biorreator degradando estrogênio (JIN et al., trabalho não publicado) e biofiltro tratando sulfeto de hidrogênio e metanol (DING et al., trabalho não publicado).

A Classe Flavobacteria (relacionada a dois clones obtidos do reator) é composta por bactérias Gram negativas na forma de haste, não móveis. São encontradas em solo e água doce em uma variedade de ambientes. Várias espécies são conhecidas por causar doenças em peixes de água doce (MUDARRIS, et al., 1994). Os dois clones encontrados neste trabalho foram relacionados a Cloacibacterium sp. presente em rio da Índia (MUKHERJEE, et al, trabalho não publicado).

Outros 46 clones foram relacionados ao Filo Proteobacteria, Classes Alphaproteobacteria (10 clones), Betaproteobacteria (31 clones), Gammaproteobacteria (4 clones) e um deles à Classe Deltaproteobacteria.

Assim como nos reatores menores, o Filo Proteobacteria representou parte significativa dos clones obtidos, porém, no caso do reator em escala de bancada, a Classe Betaproteobacteria foi mais marcante (bactérias altamente versáteis em suas capacidades de degradação). Apareceram também clones classificados como Deltaproteobacteria, que não haviam aparecido nos reatores menores.

Os clones obtidos no reator em escala de bancada similares a Alphaproteobacteria foram relacionados a microrganismos encontrados em processo de degradação de ácido arsênico (MAKI et al., trabalho não publicado), em poeiras de ambientes fechados (RINTALA et al., 2008), sedimentos de mar recebendo descarga de agricutura (SINKKO et al., trabalho não publicado), biorreator degradando clorofenol (TIIROLA et al., trabalho não publicado), bactérias redutoras de perclorato (BENDER et al., 2004) e degradação de 
pesticidas organofosforados (JIANG et al., trabalho não publicado). A semelhança com o presente trabalho está na presença de compostos tóxicos de complexa degradação.

Os 31 clones classificados como Betaproteobacteria foram relacionados a microrganismos encontrados em águas subterrâneas com concentrações de Arsênio e Ferro (CHAPON et al., trabalho não publicado), lodo Anammox (LUO E HU, trabalho não publicado), comunidade degradadora de benzeno (Weelink, et al., 2007), compostagem de logo de esgoto (ZHU E GUO, trabalho não publicado), reatores operados em bateladas sequenciais removendo fosfato (BOND, et al., 1995), solo (KYSELA et al., trabalho não publicado) e comunidade responsável pela degradação de compostos aromáticos em condições desnitrificantes (MECHICHI et al., 2002), entre outros. Os trabalhos de Kysela e Weelink são os que mais se assemelham ao reator de leito fluidificado tratando LAS por causa dos compostos com anel benzênico.

Quatro clones foram relacionados ao Filo Verrucomicrobia, Classe Verrucomicrobiae, e encontrados em solo (ELSHAHED, et al., 2008) e em biofilme de reator de fluxo ascendente em escala plena (JU e KA, trabalho não publicado). A presença destes microrganismos no presente trabalho pode ser justificada pela utilização de reator de fluxo ascendente, com biofilme, porém em escala de bancada.

Três clones foram relacionados ao Filo Acidobacteria, Classe Acidobacteria. Dois clones foram relacionados ao Filo Firmicutes, Classe Clostridia semelhante a Clostridium sp. Um clone foi relacionado ao Filo Gemmatimonadetes, Classe Gemmatimonadetes. Os 5 clones restantes foram relacionados a bactérias não classificadas.

Da mesma maneira que nos reatores menores, os 105 clones deste reator foram agrupados em Unidades Taxonômicas Operacionais (UTOs) com 97\% de similaridade. Assim, foram obtidas 69 UTOs que agruparam de 1 a 12 clones. A Tabela 5.19 apresenta os clones classificados em UTOs. 
Tabela 5.19: Clones classificados em Unidades Taxonômicas Operacionais (UTOs)

\begin{tabular}{llllll}
\hline UTO & \multicolumn{1}{c}{ Clones } & UTO & Clones & UTO & Clones \\
\hline 01 & $18,21,26,41,42,45,52,58,68,69,101,110$ & 25 & 17 & 48 & 65 \\
02 & $06,11,30,33,56,67,85,88,96,99$ & 26 & 19 & 49 & 66 \\
03 & $20,36,39,50$ & 27 & 22 & 50 & 71 \\
04 & $04,70,104$ & 28 & 23 & 51 & 72 \\
05 & $07,40,91$ & 29 & 24 & 52 & 74 \\
06 & $14,77,98$ & 30 & 25 & 53 & 75 \\
08 & 12,35 & 31 & 27 & 54 & 76 \\
09 & 16,73 & 32 & 28 & 55 & 78 \\
10 & 37,92 & 33 & 29 & 56 & 79 \\
11 & 47,100 & 34 & 31 & 57 & 81 \\
12 & 54,94 & 35 & 34 & 58 & 82 \\
13 & 57,109 & 36 & 38 & 59 & 83 \\
14 & 61,80 & 37 & 46 & 60 & 84 \\
15 & 103,106 & 38 & 48 & 61 & 86 \\
16 & 01 & 39 & 49 & 62 & 87 \\
17 & 02 & 40 & 51 & 63 & 89 \\
18 & 03 & 41 & 53 & 64 & 93 \\
19 & 05 & 42 & 55 & 65 & 95 \\
20 & 08 & 43 & 59 & 66 & 97 \\
21 & 09 & 44 & 60 & 67 & 102 \\
22 & 10 & 45 & 62 & 68 & 107 \\
23 & 13 & 46 & 63 & 69 & 108 \\
24 & 15 & 47 & 64 & & \\
\hline & & & & & \\
\end{tabular}

A seguir, são apresentadas as árvores filogenéticas referentes ao reator em escala de bancada. Para melhor vizualização, foram construídas árvores para cada uma das classes de maior destaque no reator, ou seja, Sphingobacteria (Figura 5.52), Alphaproteobacteria (Figura 5.53) e Betaproteobacteria (Figura 5.54).

A Tabela 5.20 apresenta as UTOs formadas com os clones obtidos do reator, bem como sua porcentagem de similaridade, número de acesso e descrição. 


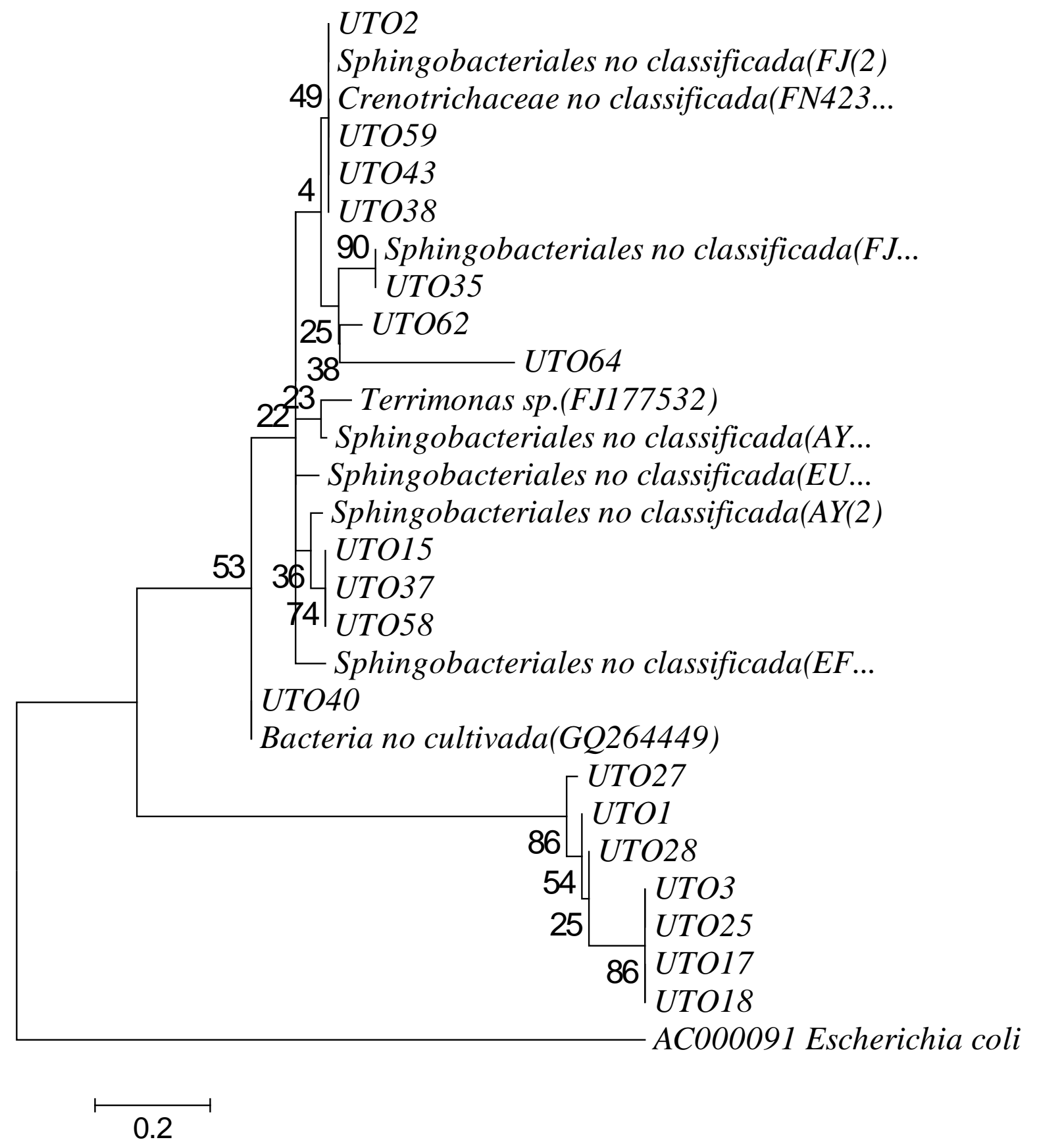

Figura 5.52: Árvore Filogenética do reator em escala de bancada mostrando a posição dos clones derivados das sequências do RNAr 16S relacionados a Classe Sphingobacteria.

Eschericha coli foi usada como grupo externo. A taxa de substituição a cada 100 nucleotídeos foi de 0,2 como indicado na barra de escala. 


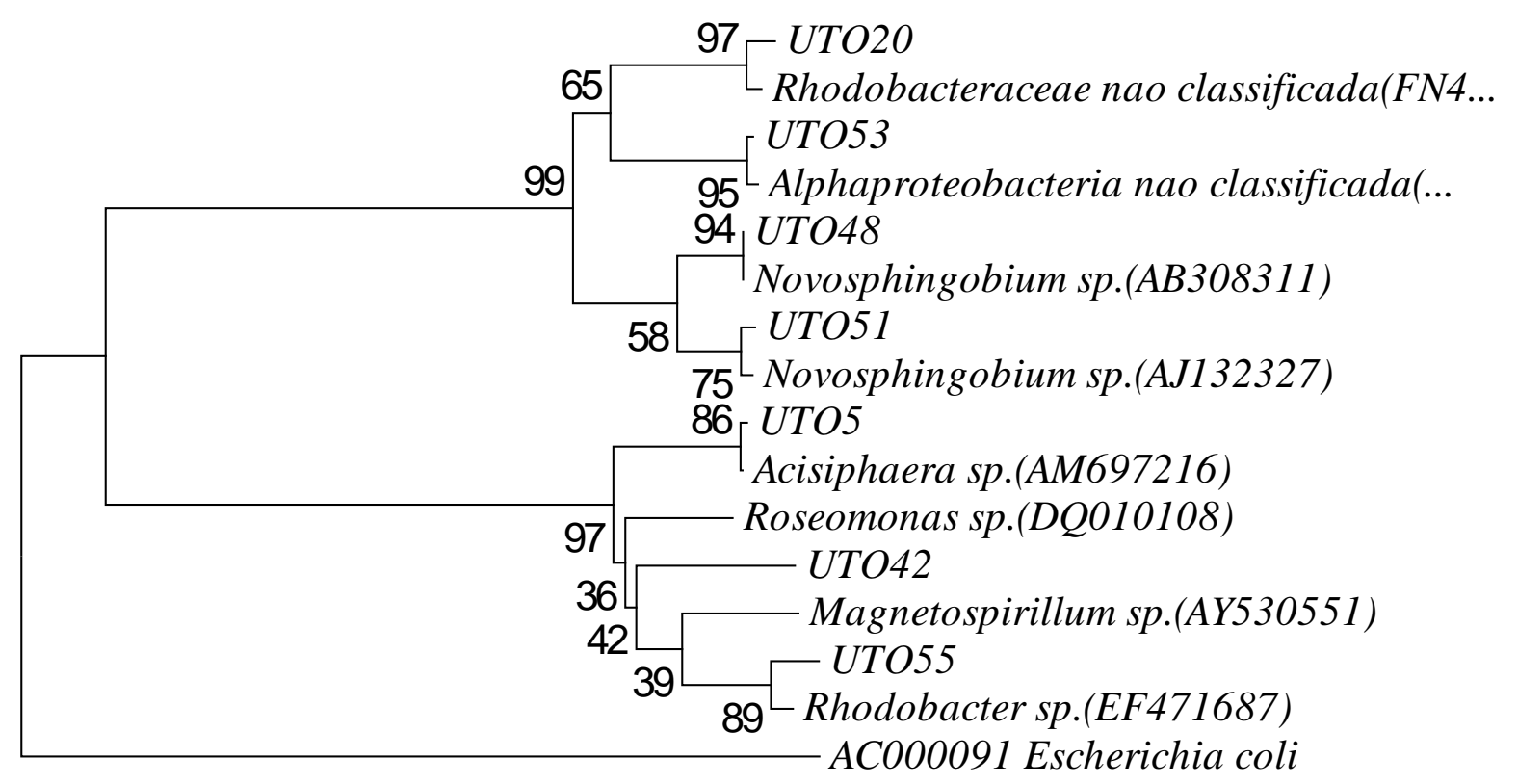

0.2

Figura 5.53: Árvore Filogenética do reator em escala de bancada mostrando a posição dos clones derivados das sequências do RNAr 16S relacionados a Classe Alphaproteobacteria. Eschericha coli foi usada como grupo externo. A taxa de substituição a cada 100 nucleotídeos foi de 0,2 como indicado na barra de escala. 


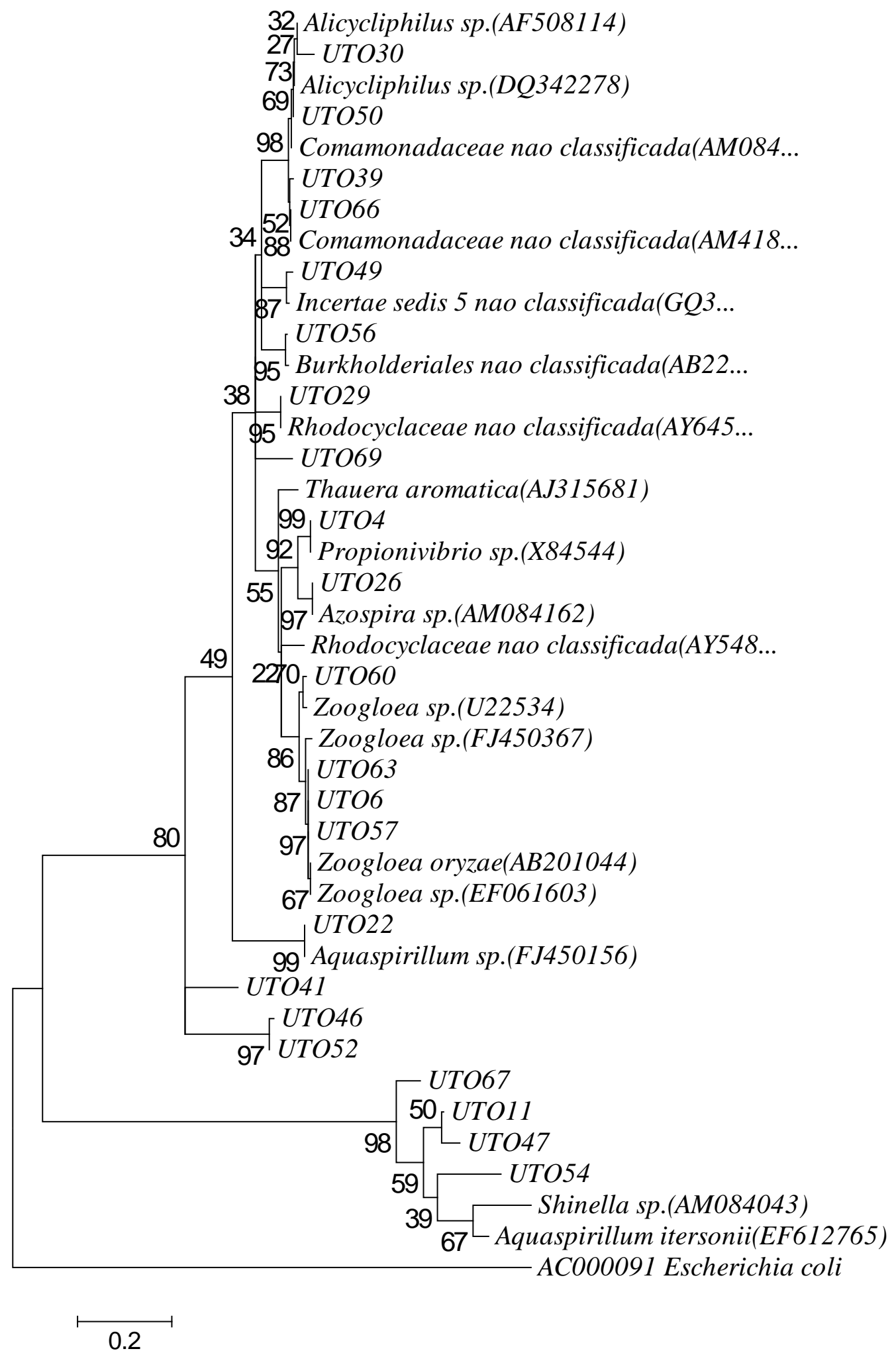

Figura 5.54:Árvore Filogenética do reator em escala de bancada mostrando a posição dos clones derivados das sequências do RNAr 16S relacionados a Classe Betaproteobacteria. Eschericha coli foi usada como grupo externo. A taxa de substituição a cada 100 nucleotídeos foi de 0,2 como indicado na barra de escala. 
Tabela 5.20: Sequências obtidas no GenBank relacionadas aos clones das amostras do reator em escala de bancada

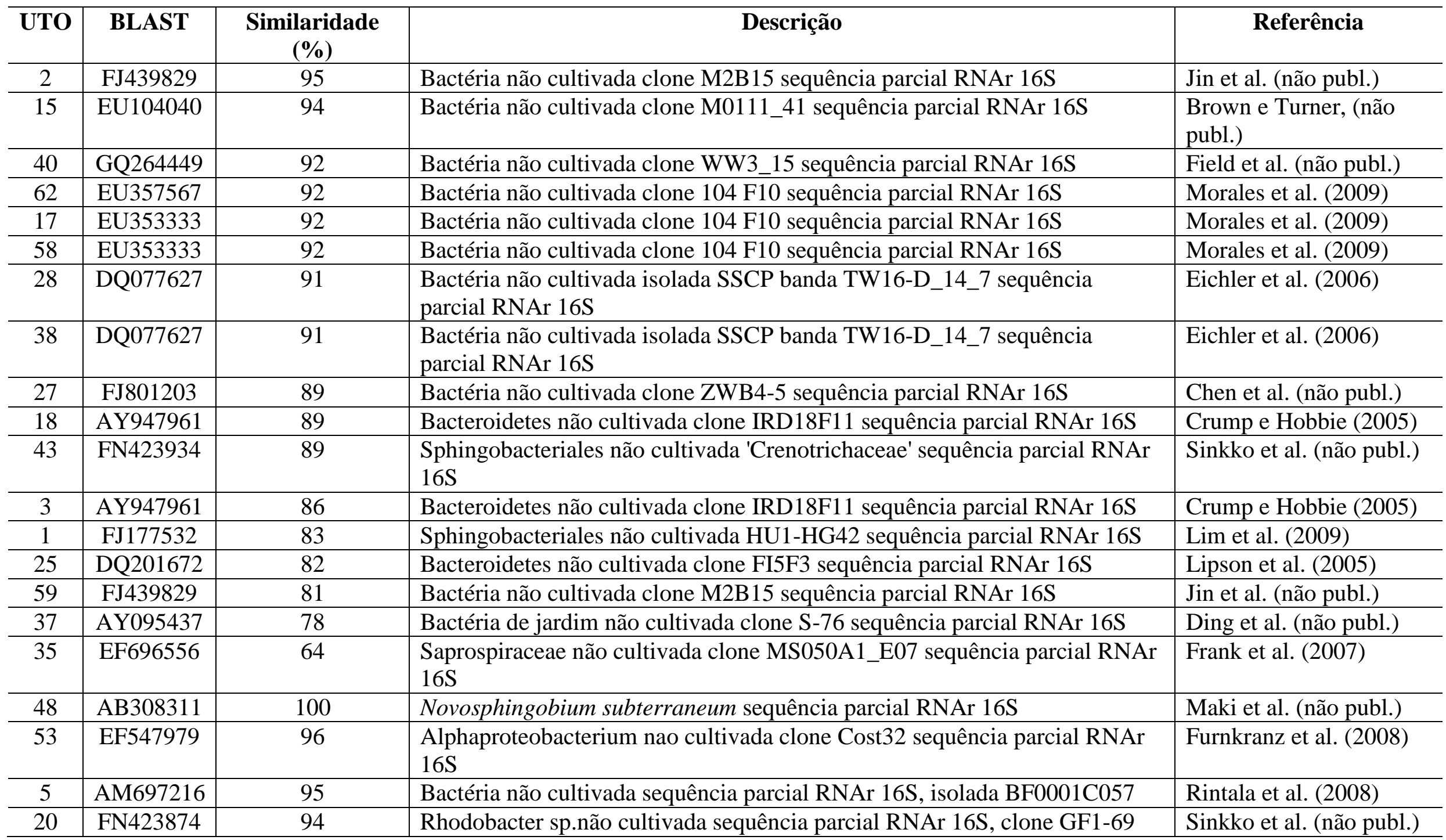


Tabela 5.20 (cont.): Sequências obtidas no GenBank relacionadas aos clones das amostras do reator em escala de bancada

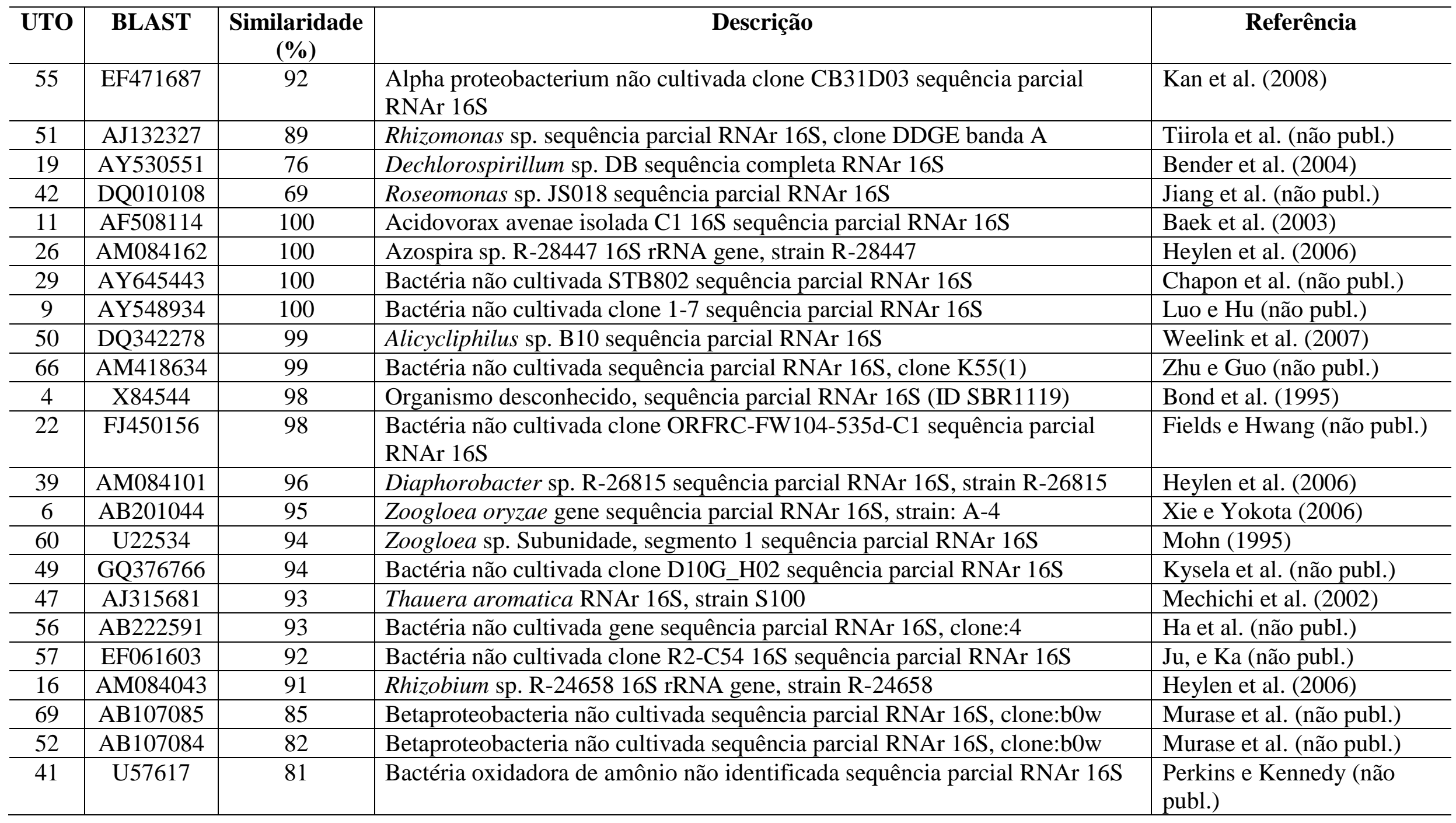


Tabela 5.20 (cont.): Sequências obtidas no GenBank relacionadas aos clones das amostras do reator em escala de bancada

\begin{tabular}{|c|c|c|c|c|}
\hline UTO & BLAST & $\begin{array}{c}\text { Similaridade } \\
(\%)\end{array}$ & Descrição & Referência \\
\hline 67 & EU376266 & 77 & Bactéria não cultivada clone sls1837 sequência parcial RNAr 16S & $\begin{array}{l}\text { Liesegang et al. (não } \\
\text { publ.) }\end{array}$ \\
\hline 54 & AM422676 & 77 & $\begin{array}{l}\text { Eubacterium sp. não cultivada sequência parcial RNAr 16S, isolada DGGE agosto } \\
\text { 2003, banda } 67\end{array}$ & Eller et al. (2007) \\
\hline 46 & AM706568 & 69 & $\begin{array}{l}\text { Betaproteobacteria não cultivada sequência parcial RNAr 16S, clone } \\
\text { betaproteobacteria_Raunefjorden } 12\end{array}$ & Muhling et al. (2008) \\
\hline 8 & AY178536 & 100 & Aeromonas sp. R-17488 sequência parcial RNAr 16S & Goris et al. (2003) \\
\hline 44 & AY537709 & 100 & Bactéria não cultivada clone $1 \mathrm{G} 05$ sequência parcial RNAr 16S & Rawls et al. (2004) \\
\hline 68 & AB120346 & 100 & Pseudomonas sp. 12M16 sequência parcial RNAr 16S & Maki et al. (não publ.) \\
\hline 14 & EF061551 & 91 & Bactéria não cultivada clone R1-C41 16S sequência parcial RNAr 16S & Ju e Ka (não publ.) \\
\hline 21 & FJ933342 & 91 & $\begin{array}{l}\text { Acidobacteriaceae não cultivada clone REG_R2P4_F9 sequência parcial RNAr } \\
16 \mathrm{~S}\end{array}$ & Silva et la. (não publ.) \\
\hline 34 & AP009153 & 91 & Gemmatimonas aurantiaca T-27 DNA, genoma completo & $\begin{array}{l}\text { Takasaki et al. (não } \\
\text { publ.) }\end{array}$ \\
\hline 32 & FJ265446 & 80 & Bactéria não cultivada clone ISA01131 sequência parcial RNAr 16S & Qin et al. (não publ.) \\
\hline 45 & FJ265446 & 71 & Bactéria não cultivada clone ISA01131 sequência parcial RNAr 16S & Qin et al. (não publ.) \\
\hline 13 & AY328729 & 100 & Bactéria não cultivada DSSD30 sequência parcial RNAr 16S & Williams et al. (2004) \\
\hline
\end{tabular}


Tabela 5.20 (cont.): Sequências obtidas no GenBank relacionadas aos clones das amostras do reator em escala de bancada

\begin{tabular}{c|c|c|l|l}
\hline UTO & BLAST & $\begin{array}{c}\text { Similaridade } \\
(\%)\end{array}$ & \multicolumn{1}{|c}{ Descrição } & Referência \\
\hline 61 & AY328558 & 93 & Bactéria não cultivada DSSD30 sequência parcial RNAr 16S & $\begin{array}{l}\text { Williams et al. } \\
(2004)\end{array}$ \\
\hline 36 & AJ630296 & 92 & $\begin{array}{l}\text { Cytophagales/green sulfur bacteria não identificada OPB56 sequência parcial RNAr } \\
\text { 16S, clone MFC-EB28 }\end{array}$ & Kim et al. (2006) \\
\hline 23 & AJ630296 & 92 & $\begin{array}{l}\text { Cytophagales/green sulfur bacteria não identificada OPB56 sequência parcial RNAr } \\
\text { 16S, clone MFC-EB28 }\end{array}$ & Kim et al. (2006) \\
\hline
\end{tabular}




\subsubsection{Considerações}

O reator de leito fluidificado em escala de bancada preenchido com areia como material suporte apresentou microrganismos semelhantes aos encontrados no reator menor (R4 areia). No entanto, menor diversidade foi observada uma vez que 12 classes foram obtidas em R4 e 10 no reator maior.

Algumas classes não foram encontradas no reator em escala de bancada, enquanto que outras como, por exemplo, Betaproteobacteria, se manteve presente nos dois reatores. Neste caso específico, porém, a presença foi muito mais representativa no reator maior.

É possível que o maior tempo de operação do reator em escala de bancada, assim como a maior concentração de surfactante fornecida ao longo do tempo tenham favorecido o crescimento de determinados grupos microbianos em detrimento de outros. Como a porcentagem de remoção do LAS se manteve elevada em ambos os reatores, tal comportamento pode indicar uma seleção favorecendo os microrganismos envolvidos na degradação do surfactante.

\subsection{Técnica dos Tubos Múltiplos}

Amostra da biomassa presente no material suporte do reator em escala de bancada (areia) foi retirada ao final de operação do reator quando a concentração de LAS era de $45,8 \pm 5,4 \mathrm{mg} / \mathrm{L}$. Nesta fase as remoções de matéria orgânica e LAS estavam em $91 \pm 2 \%$ e $93 \pm 3 \%$, respectivamente.

Após o período de incubação (30 dias a $30^{\circ} \mathrm{C}$ ), os frascos, em quintuplicata para diluições de $10^{-1}$ a $10^{-13}$, foram analisados para verificar o crescimento dos seguintes grupos microbianos: (1) bactérias anaeróbias totais - avaliado pela turvação do meio, (2) bactérias redutoras de sulfato (BRS) - avaliado pela produção de sulfeto de hidrogênio, conforme metodologia desenvolvida por Sakamoto (1996) e (3) arquéias metanogênicas - determinado pela formação de metano por meio de cromatografia gasosa.

A quantificação de bactérias pelo método do NMP revelou que as bactérias anaeróbias totais representaram $3,98 \times 10^{10} \mathrm{NMP} / \mathrm{g} \mathrm{STV}$, enquanto as BRS equivaleram a $3,75 \times 10^{9}$ $\mathrm{NMP} / \mathrm{g}$ STV, ou 9,4\% do total. O valor para as arquéias metanogênicas foi $1,93 \times 10^{4} \mathrm{NMP} / \mathrm{g}$ STV, o que representou menos de $1 \%$ das bactérias anaeróbias totais. A diferença entre os três grupos avaliados pode ser visualizada na Figura 5.55. 


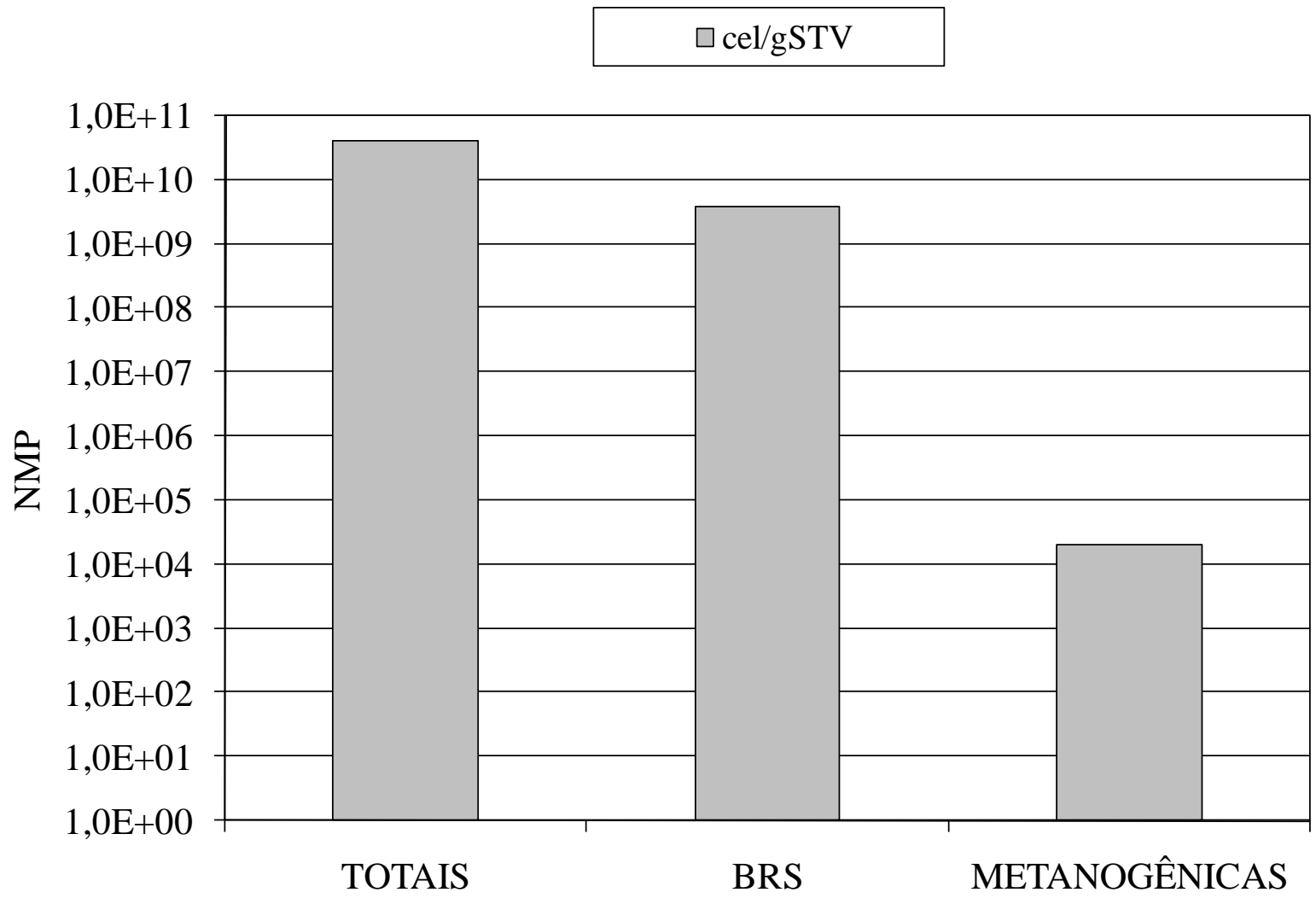

Figura 5.55: Quantificação dos grupos microbianos pelo NMP

\subsection{Anaerobiose no Reator}

Realizou-se teste com corante resarzurina na alimentação do reator conforme descrito no item 4.5 para constatar a anaerobiose do reator.

Após algumas horas de alimentação com resarzurina, a coloração do reator adquiriu tonalidade rósea, indicando potencial redox entre -200 e $200 \mathrm{mV}$. No entanto, na areia com biofilme, a resarzurina tornou-se transparente, indicando anaerobiose estrita nesse trecho do reator. Nessa condição foi possível observar arquéias metanogênicas, principalmente bacilos fluorescentes hidrogenotróficos e Methanosarcina. Essas arquéias são anaeróbias estritas, todavia, cresceram em condição intermediária de potencial redox. É importante destacar que tais células usam compostos finais da degradação anaeróbia, ou seja, $\mathrm{H}_{2} / \mathrm{CO}_{2}$, acetato, formiato, metanol, entre outros. Assim, como comprovado pela análise filogenética de reatores semelhantes a este, foram identificadas várias bactérias anaeróbias, possivelmente capazes de degradar o LAS e também utilizar o co-substrato, sacarose, para produção de compostos importantes para metanogênese. A constatação de consórcio anaeróbio 
representado por bactérias anaeróbias, BRS e arquéias metanogênicas foi obtida no método do NMP, cuja realização foi efetuada em condições de anaerobiose estrita.

A Figura 5.56 apresenta imagem do reator após adição do corante resarzurina na alimentação.

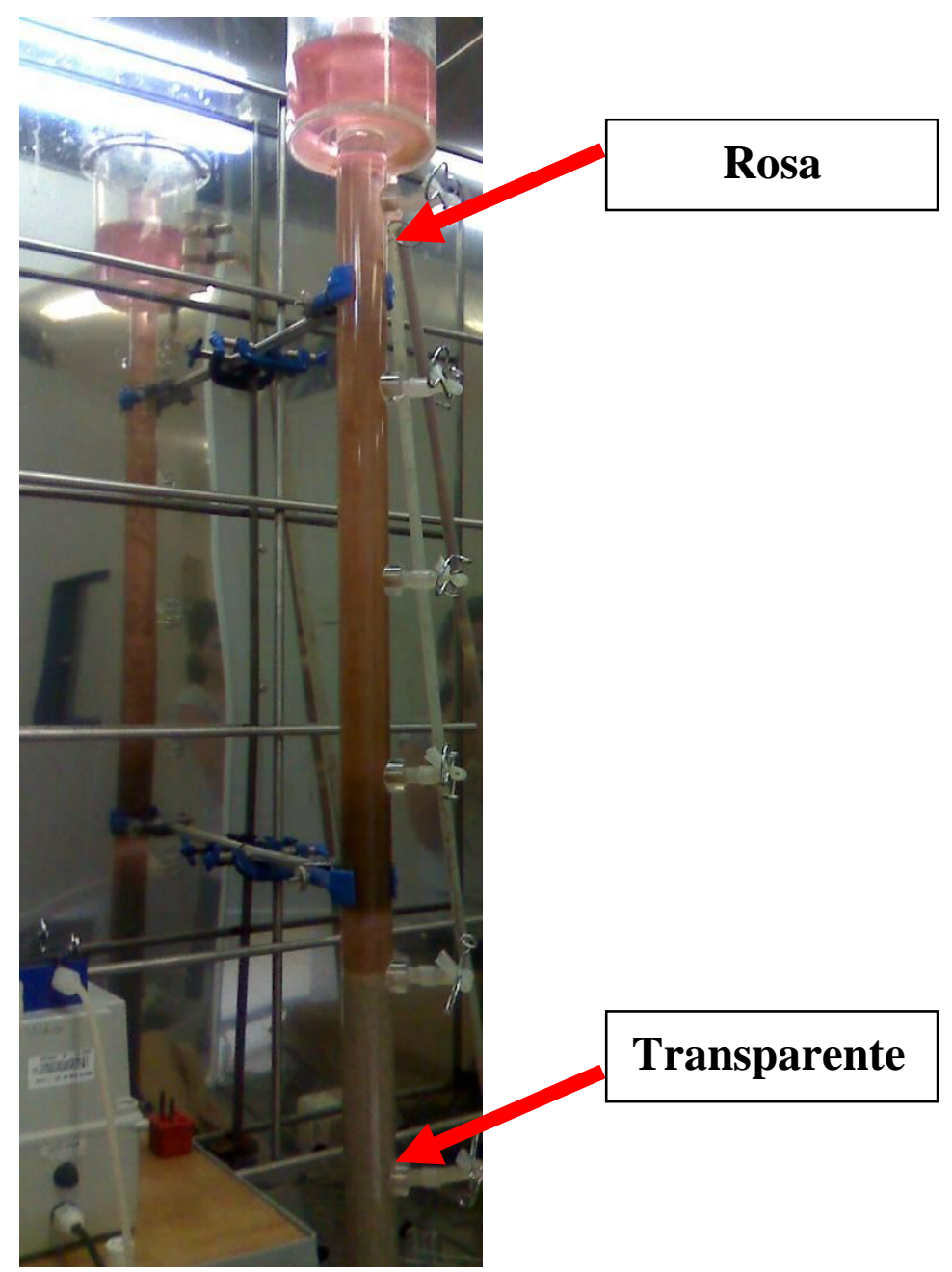

Figura 5.56: Reator de Leito Fluidificado alimentado com resarzurina para constatação de anaerobiose no sistema 


\section{CONCLUSÕES}

$>\mathrm{O}$ reator anaeróbio de leito fluidificado foi extremamente eficiente na remoção do LAS, apresentando valores muito mais elevados que os encontrados na literatura para concentrações relativamente altas do surfactante (até $45 \mathrm{mg} / \mathrm{L}$ ). Variações na concentração afluente não afetou a remoção de $93 \%$ em média.

Quanto a hidrodinâmica do reator, o efeito de diluição da recirculação e as excelentes características de transferência de massa do sistema de leito fluidificado permitiram tais resultados.

Areia e pérolas de vidro foram os materiais suporte que apresentaram maior porcentagem média de remoção de LAS (99\%) seguidos pelo carvão ativado (95\%) e argila expandida (81\%).

$>$ Os valores de remoção de DQO se mantiveram elevados e estáveis em todas as condições estudadas (acima de 90\%) mesmo com o aumento da concentração de LAS.

Ensaios de adsorção em batelada mostraram que os materiais suporte testados não apresentam grande capacidade de adsorver o LAS. Carvão ativado adsorveu 0,22 mg LAS/gsuporte. Argila expandida adsorveu 0,43 mg LAS/gsuporte. Pérolas de vidro e areia não adsorveram o surfactante.

Por meio das análises das sequências do fragmento do gene 16S RNAr foi possível constatar grande diversidade microbiana como organismos pertencentes aos Filos Bacteroidetes, Firmicutes, Actinobacteria e Proteobacteria, indicando a necessidade de consórcio microbiano para degradação do surfactante LAS. 


\section{SUGESTÕES PARA TRABALHOS FUTUROS}

Com base na experiência adquirida durante este trabalho, sugere-se:

Estudar o efeito de carga de choque ao reator de leito fluidificado.

$>$ Estudo da técnica de espectrometria de massa para determinação dos intermediários da degradação anaeróbia do LAS e assim tentar estabelecer uma possível rota metabólica. Diminuir o tempo de detenção hidráulica usado na operação do reator.

$>$ Utilizar águas residuárias reais contendo detergente como fonte de LAS no afluente do reator. 


\section{REFERÊNCIAS*}

ALMENDARIZ, F.J., MERÁZ, M., SOBERÓN, G., MONROY, O. Degradation of linear alkylbenzene sulphonates (LAS) in an acidogenic reactor bioaugmented with a Pseudomonas aeruginosa (M113) strain. Water Science Technology, v. 44, p. 183-188, 2001.

ÁLVAREZ-MUÑOZ, D., LARA-MARTÍN, P.A., BLASCO, J., GÓMEZ-PARRA, A., GONZÁLEZ-MAZO, E. Presence, biotransformation and effects of sulfophenylcarboxilic acids in the benthic fish Solea senegalensis. Environmental International, v. 33, p. 565-570, 2007.

ALVAREZ-MUÑOZ, D., GÓMEZ-PARRA, A., BLASCO, J., SARASQUETE, C., GONZÁLEZ-MAZO, E. Oxidative stress and histopathology damage related to the metabolismo of dodecylbenzene sulfonate in Senegalese sole. Chemosphere, v. 74, p. 1216$1223,2009$.

AMORIM, E.L.C., BARROS, A.R., DAMIANOVIC, M.H.R.Z., SILVA, E.L. Anaerobic fluidized bed reactor with expanded Clay as support for hydrogen production through dark fermentation of glucose. International Journal of Hydrogen Energy, v.34, p. 783-790, 2009.

ANDREES, S., HARMSEN, D., KROPPENSTEDT, R.M., MAUCH, H., ROTH, A. Phylogenetic analysis of the genus Nocardia based on 16S rDNA sequences. Trabalho não publicado.

APHA/AWWA/Water Environment Federation. Standard Methods for the Examination of water and wastewater. 20th ed. Washington, DC, USA, 2005.

\footnotetext{
* De acordo com: 
BAEK,S.H., KIM,K.H., YIN,C.R., JEON,C.O., IM,W.T., KIM,K.K., LEE,S.T. Isolation and characterization of bacteria capable of degrading phenol and reducing nitrate under lowoxygen conditions. Current Microbiology v. 47 n. 6, p. 462-466, 2003.

BANIULYTE, D., FAVILA, E., KELLY, J.J. Shifts in microbial community composition following surface application of dredged river sediments. Microbial Ecology, v. 57, n. 1, p. 160-169, 2009.

BARBIERI E., NGAN P. V., GOMES V. Efeito do LAS-C12 no metabolismo de rotina de tainhas em função da temperatura em três salinidades. In: Espíndola E. L. G., et al. Ecotoxicologia Perspectivas para o século XXI. Editora Rima, São Carlos, SP. p.293-308, 2000.

BASAR, C.A., KARAGUNDUZ, A., CAKICI, A., KESKINLER, B. Removal of surfactants by powered activated carbon and microfiltration. Water Research, v. 38, p. 2117-2124, 2004.

BEHRENS, S., AZIZIAN, M.F., MCMURDIE, P.J., SABALOWSKY, A., DOLAN, M.E., SEMPRINI, L., SPORMANN, A.M. Monitoring abundance and expression of 'dehalococcoides' species chloroethene-reductive dehalogenases in a tetrachloroethenedechlorinating flow column. Applied and Environmental Microbiology, v. 74, n. 18, p. 5695-5703, 2008.

BENDER,K.S., RICE,M.R., FUGATE,W.H., COATES,J.D., ACHENBACH,L.A. Metabolic primers for detection of (Per)chlorate-reducing bacteria in the environment and phylogenetic analysis of cld gene sequences. Applyed Environmental Microbiology v. 70 n. 9, p.5651$5658,2004$.

BERGEY, D.H. Bergey’s Manual of Systematic Bacteriology, 1986.

BERNA J.L., FERRER J, MORENO A., PRATS D., BEVIA F.R. The fate of LAS in the environment. Tenside Surfactants Detergent v. 26, p. 101-107, 1989.

BOND,P.L., HUGENHOLTZ,P., KELLER,J., BLACKALL,L.L. Bacterial community structures of phosphate-removing and non-phosphate-removing activated sludges from 
sequencing batch reactors. Applyed Environmental Microbiology v. 61 n. 5, p. 1910-1916, 1995.

BORSATO, D., GALÃO, O.F., MOREIRA, I. Detergentes naturais e sintéticos. Londrina. Editora UEL, 1999. 131p.

BROWN,C.E., TURNER,S.J. Evidence for the Comamonadaceae as determinants of activated sludge settling performance. Trabalho não publicado.

BRUNNER, P.H., CAPRI, S., MARCOMINI, A., GIGER, W. Occurrence and behaviour of linear alkylbenzenesulphonates, nonylphenol, nonylphenol mono- and nonylphenol diethoxylates in sewage and sewage sludge treatment. Water Research, v. 22, p. 1465-1472, 1988.

BURRELL, P.C., KELLER, J., BLACKALL, L.L. Microbiology of a nitrite-oxidizing bioreactor. Applied and Environmental Microbiology, v. 64, n. 5, p. 1878-1883, 1998.

CHAPON, V., THORAL, S., YANEZ-NEAMAN, C., CHEVENET, F., CHRISTEN, R., ROSE, J., GARNIER, J.-M., VON GEEN, A., HEULIN, T. Comparison of bacterial diversity in Bangladesh groundwaters having contrasting As and Fe concentrations. Trabalho não publicado.

CHEN,X., FENG,S., ZHANG,H. Investigation of Bacterial Community Diversity in Water of Zoige Wetland by PCR-DGGE and 16S rDNA Clone Library. Trabalho não publicado.

CHILIMA, B.Z., CLARK, I.M., FLOYD, S., FINE, P.E., HIRSCH, P.R. Distribution of Environmental Mycobacteria in Karonga District, Northern Malawi. Applied and Environmental Microbiology, v. 72, n. 4, p. 2343-2350, 2006.

CHON, K., CHON, K., CHANG, J.-S., OH, H., LEE, E., CHO, J. Technical Note: Community of bacteria attached on the PVDF MF membrane surface fouled from drinking water treatment, in Seoul, Korea. Trabalho não publicado. 
CHOUARI, R., PASLIER, D., DAUGA, C., DAEGELEN, P., WEISSENBACH, J., SGHIR A. Novel Major Bacterial Candidate Division within a Municipal Anaerobic Sludge Digester. Applied and Environmental Microbiology, v. 71, n. 4, p. 2145-2153, 2005.

COOPER, P.F., SUTTON, P.M. Treatment of wastewaters using biological fluidized beds. Chemical Engineering, v. 393, p. 392-405, 1983.

COSTA, A.R.F., LOPES, M.L., CORVELO, T.C.O., SCHNNEIDER, M.P.C., SILVA, M.S., LEAO, S.C., LIMA, K.V.B. Genetic diversity of rapidly growing mycobacteria isolates from pulmonary specimens in the Para state (Brazil). Trabalho não publicado.

CRUMP,B.C., HOBBIE,J.E. Synchrony and seasonality in bacterioplankton communities of two temperate rivers. Limnoogy. Oceanografic v. 50 n. 6, p. 1718-1729, 2005.

CRUZ, K., SUTTLE, K.B., BRODIE, E.L., ANDERSEN, G.L., BANFIELD, J.F. Effects of five years of increased precipitation on soil microbial communities in a California grassland. Trabalho não publicado.

DADHWAL, M., SINGH, A., PRAKASH, O., GUPTA, S.K., KUMARI, K., SHARMA, P., JIT, S., VERMA, M., HOLliger, C., LAL, R. Proposal of biostimulation for hexachlorocyclohexane $(\mathrm{HCH})$-decontamination and characterization of culturable bacterial community from high-dose point $\mathrm{HCH}$-contaminated soils. Journal of Applied Microbiology, v. 106, n. 2, p. 381-392, 2009.

DAMIANO, E.S.G. E SILVA, E.L. Tratamento da vinhaça em reator anaeróbio de leito fluidificado. Anais do IV Seminário do Projeto Temático - Desenvolvimento, análise, aprimoramento e otimização de reatores anaeróbios para tratamento de águas residuárias, p. 235-244, 2005.

DAMIANOVIC, M.H.R.Z. Degradação de pentaclorofenol (PCP) em reatores anaeróbios horizontais de leito fixo (RAHLF). 1997. Tese de Doutorado, EESC, USP, São Carlos. 
DAVIS, K.E., JOSEPH, S.J., JANSSEN, P.H. Effects of growth medium, inoculum size, and incubation time on culturability and isolation of soil bacteria. Applied and Environmental Microbiology, v. 71, n. 2, p. 826-834, 2005.

DE NARDI, I.R. Degradação de benzeno, tolueno, etilbenzeno e xilenos (BTEX) em reator anaeróbio horizontal de leito fixo (RAHLF). 2002 Tese de Doutorado, EESC, USP, São Carlos.

DENGER, K. AND COOK, A.M. Linear alkylbenzene sulphonate (LAS) bioavailable to anaerobic bacteria as a source os sulphur. Journal of Applied Microbiology v. 86, p. 165-168, 1999.

DENGER, K., KERTESZ, M.A., VOCK, E.H., SCHON, R., MÄGLI, A., COOK, A.M. Anaerobic desulfonation of 4-tolysulfonate and 2-(4sulfophenyl) butyrate by a Clostridium sp. Applied and Environmental Microbiology, v. 62, p. 1526-1530, 1996.

DESAI, C., PARIKH, R.Y., VAISHNAV, T., SHOUCHE, Y.S., MADAMWAR, D. Tracking the influence of long-term chromium pollution on soil bacterial community structures by comparative analyses of 16S rRNA gene phylotypes. Research Microbiology, v. 160, n. 1, p. 1-9, 2009.

DI CORCIA, A. Characterization of surfactants and their biointermediates by liquid chromatography - mass spectrometry. Journal of Chromatography A, v. 794, p. 165-185, 1998.

DIALlO, M.D., MARTENS, M., VLOEMANS, N., COUSIN, S., VANDEKERCKHOVE, T.T.M., NEYRA, M., DE LAJUDIE, P., WILLEMS, A., GILLIS, M., VYVERMAN, W., VAN DER GUCHT, K. Phylogenetic analysis of partial bacterial 16S rDNA sequences of tropical grass pasture soil under Acacia tortilis subsp. Raddiana in Senegal. Systematic and Applied Microbiology, v. 27, n. 2, p. 238-252, 2004.

DILLALO, R., ALBERTSON, O.E. Volatile acids by direct tritation. Journal WPCF, v. 33, p. 356-365, 1961. 
DING,Y., WHITMAN,W.B., DAS,K., KASTNER,J.R. Changes in the microbial community of a biofilter-treating hydrogen sulfide and methanol. Trabalho não publicado.

DOAN, H.D., SAIDI, M. Simultaneous removal of metal íons and linear alkylbenzene sulfonate by combined electrochemical and photocatalytic process. Journal of Hazardous Materials, v. 159, p. 557-567, 2008.

DRZYZGA, O., NAVARRO-LLORENS, M., FERNANDEZ DE LAS HERAS, L., GARCIAFERNANDEZ, E., PERERA, J. Gordonia cholesterolivorans sp. nov., a cholesteroldegrading actinomycete isolated from sewage sludge. International Journal of Systematic and Evolutionary Microbiology, in press, 2008 .

DUARTE, I.C.S. Caracterização Microbiológica da Remoção e Degradação de Alquilbenzeno Linear Sulfonado (LAS) em Reatores Anaeróbios com Biofilme e Células Planctônicas. 2006. Tese de doutorado, EESC, USP, São Carlos.

DUARTE, I.C.S., OLIVEIRA, L.L., BUZZINI, A.P., ADORNO, M.A.T., VARESCHE, M.B.A. Development of a Method by HPLC to Determine LAS and its Application in Anaerobic Reactors. Journal of the Brazilian Chemical Society, v. 17, n. 7, p. 1360-1367, 2006.

DUARTE, I.C.S., OLIVEIRA, L.L., SAAVEDRA, N.K.D., FANTINATTI-GARBOGGINI, F., OLIVEIRA ,V. M., VARESCHE, M.B.A. Evaluation of the microbial diversity in a horizontal-flow anaerobic immobilized biomass reactor treating linear alkylbenzene sulfonate. Biodegradation, v. 19, p. 375-385, 2008.

DUARTE, I.C.S., OLIVEIRA, L.L., SAAVEDRA, N.K.D., FANTINATTI-GARBOGGINI, F., MENEZES, C.B.A, OLIVEIRA ,V. M., VARESCHE, M.B.A. Treatment of linear alkylbenzene sulfonate in a horizontal anaerobic immobilized biomass reactor. Bioresource Technology, v. 101, n. 2, p. 606-612, 2010.

DUARTE, I.C.S., OLIVEIRA, L.L., MAYOR, M.S., OKADA, D.Y., VARESCHE, M.B.A. Degradation of detergent (linear alkylbenzene sulfonate) in an anaerobic stirred sequencing 
batch reactor containing granular biomass. Biodeterioration and Biodegradation, in press, 2010 .

EICHHORN P., RODRIGUEZ S. V., BAUMANN W., KNEPPER T. P. Incomplete degradation of linear alkylbenzene sulfonate surfactants in Brazilian surface waters and pursuit of their metabolites in drinking waters. The Science of the Total Environmental, v. 284, p. 123-134, 2002.

EICHLER,S., CHRISTEN,R., HOLTJE,C., WESTPHAL,P., BOTEL,J., BRETTAR,I., MEHLING,A., HOFLE,M.G. Composition and Dynamics of Bacterial Communities of a Drinking Water Supply System as Assessed by RNA- and DNA-Based 16S rRNA Gene Fingerprinting. Applyed Environmental Microbiology v. 72 n. 3, p. 1858-1872, 2006.

ELLER,G., DEINES,P., KRUEGER,M. Possible sources of methane derived carbon for chironomid larvae. Aquatic Microbial Ecology v. 46 n. 3, p. 283-293, 2007.

ELSHAHED,M.S., YOUSSEF,N.H., $\quad$ SPAIN,A.M., $\quad$ SHEIK,C., $\quad$ NAJAR,F.Z., SUKHARNIKOV,L.O., ROE,B.A., DAVIS,J.P., SCHLOSS,P.D., BILEY,V.L., KRUMHOLZ,L.R. Novelty and uniqueness patterns of rare members of the soil biosphere. Applyed Environmental Microbiology, v. 74, n 17, p, 5422-5428, 2008.

FALK, M.W., SONG, K.-G., MATIASEK, M.G., WUERTZ, S. Bacterial Community Dynamics in Replicate Membrane Bioreactors using Terminal Restriction Fragment Length Polymorphism (T-RFLP) Analysis. Trabalho não publicado.

FAN, L.S. Gas-liquid-solid fluidization engineering. Brenner, N. (Ed.). Buttherworths series in Chemical Engineering, 1989.

FIELD, E.K., D'IMPERIO, S., MILLER, A., VANENGELEN, M.R., GERLACH, R., LEE, B.D., APEL, W.A., PEYTON, B.M. Bacterial Community Structure at a Simulated Low Level Waste Site. Trabalho não publicado.

FIELDS, M.W., YAN, T., ZHOU, J. Phylogenetic and functional biomarkers as indicators of bacterial community responses to mixed-waste contamination. Trabalho não publicado. 
FIELDS,M.W., HWANG,C. Bacterial community succession during in situ uranium bioremediation: spatial similarities along controlled flow paths. Trabalho não publicado.

FORESTI, E., ZAIAT, M., CABRAL, A.K.A., DEL NERY, V. Horizontal-Flow Anaerobic Immobilized Sludge (HAIS) reactor for paper industry wastewater treatment. Brazilian Journal of Chemical Engineering, v. 12, p. 235-239, 1995.

FOX K., HOLT M., DANIEL M., BUCKLAND H., GUYMER I. Removal of linear alkylbenzene sulfonate from a small Yorkshire stream: contribution to GREAT-ER project. Science Total Environmental, v. 251/252, p. 265-275, 2000.

FRANK,D.N., ST AMAND,A.L., FELDMAN,R.A., BOEDEKER,E.C., HARPAZ,N., PACE,N.R. Molecular-phylogenetic characterization of microbial community imbalances in human inflammatory bowel diseases. Proc. Natl. Acad. Sci. U.S.A. v. 104 n. 34, p. 1378013785, 2007.

FURNKRANZ,M., WANEK,W., RICHTER,A., ABELL,G., RASCHE,F., SESSITSCH,A. Nitrogen fixation by phyllosphere bacteria associated with higher plants and their colonizing epiphytes of a tropical lowland rainforest of Costa Rica. ISME J v. 2 n. 5, p. 561-570, 2008.

GARCÍA ENCINA, P.A., HIDALGO, M.D. Influence of substrate feed patterns on biofilm development in anaerobic fluidized bed reactors (AFBR). Process Biochemistry, v. 40, p. 2509-2516, 2005.

GARCIA, M.T., CAMPOS, E., MARSAL, A., RIBOSA, I. Biodegradability and toxicity of sulphonate-based surfactants in aerobic and anaerobic aquatic environments. Water Research, v. 43, p. 295-302, 2009.

GORIS,J., BOON,N., LEBBE,L., VERSTRAETE,W., VOS,P. Diversity of activated sludge bacteria receiving the 3-chloroaniline-degradative plasmid pC1gfp. FEMS Microbiology Ecology, v. 46, n. 2, p. 221-230, 2003. 
GRICE, E.A., KONG, H.H., RENAUD, G., YOUNG, A.C., BOUFFARD, G.G., BLAKESLEY, R.W., WOLFSBERG, T.G., TURNER, M.L., SEGRE, J.A. A diversity profile of the human skin microbiota. Genome Research, v. 18, p. 1043-1050, 2008.

GRIFFITHS, R.I., WHITELEY, A.S., O’DONNELL, A.G. Rapid Method for coextration of DNA from natural environments for analysis of ribossomal DNA and rRNA-based microbial community composition. Applied and Environmental Microbiology, v. 66, n. 12, p. 54885491, 2000.

GU, A.Z., STENSEL, H.D., STRAND, S.E., STALEY, J.T., SMIDT, H., STAHL, D.A. An Anaerobic VC-Enriched Consortium Is Dominated By NovelFlexibacter Species. Trabalho não publicado.

HA,D.T., KUTSUMOTO,R., KOYAMA,T., FUJII,T., FURUKAWA,K. Evaluation of the swim-bed attached-growth process for E36nitrification of Hanoi Groundwater containing high levels of iron. Trabalho não publicado.

HA, S.R., VINITNANTHARAT, S. Competitive removal of phenol and 2,4-dichlorophenol in biological activated carbon system. Environmental Technology, v. 21, p. 387-396, 2000.

HAROUN, M., IDRIS, A. Treatment of textile wastewater with Ana anaerobic fluidized bed reactor. Desalination, v. 237, p. 357-366, 2009.

HATAMURA E., EYSINK G. J., BEVILACQUA J. E., MORAES R. P. Enriquecimento das espumas por substâncias químicas como agente de exportação de poluentes no Rio Tietê./ Relatório Técnico. Cetesb, 1993.

HEIJNEN, J.J., MULDER, A., ENGER, W., HOEKS, F. Review on the application of anaerobic fluidized bed reactors in wastewater treatment. Chemical Engineering Journal 4, p. B37-B50, 1989.

HERRERA, A., HERY, M., STACH, J.E.M., JAFFRE, T., NORMAND, P., NAVARRO, E. Species richness and phylogenetic diversity comparisons of soil microbial communities 
affected by nickel-mining and revegetation efforts in New Caledonia. European Journal of Soil Biology, v. 43, n. 2, p. 130-139, 2007.

HERY, M., HERRERA, A., VOGEL, T.M., NORMAND, P., NAVARRO, E. Effect of carbon and nitrogen input on the bacterial community structure of Neocaledonian nickel mine spoils. FEMS Microbiology Ecology, v. 51, n. 3, p. 333-340, 2005.

HEYLEN, K., VANPARYS, B., WITTEBOLle, L., VERSTRAETE, W., BOON, N., DE VOS, P. Cultivation of denitrifying bacteria: optimization of isolation conditions and diversity study. Applied and Environmental Microbiology, v. 72, n. 4, p. 2637-2643, 2006.

HOFFMANN, A., THIMM, T., DRÖGE, M., MOORE, E.R.B., MUNCH, J.C., TEBBE, C.C. Intergeneric Transfer of Conjugative and Mobilizable Plasmids Harbored by Escherichia coli in the Gut of the Soil Microarthropod Folsomia candida (Collembola). Applied and Environmental Microbiology, v. 64, n. 7, p. 2652-2659, 1998.

HOLT M.S., FOX K.K., BURFORD M., DANIEL M., BUCKLAND H. UK monitoring study on the removal of linear alkylbenzene sulphonate in trickling filter type sewage treatment plants Contribution to GREAT-ER project \#2. Science Total Environment, v. 210/211, p. 255-269, 1998.

HORNER-DEVINE, M.C., LEIBOLD,M.A., SMITH, V.H., BOHANNAN, B.J.M. Bacterial diversity patterns along a gradient of primary productivity. Ecology Letter, v. 6, p. 613-622, 2003.

HOUSE, W.H., FARR, I.S. Adsorption of sulphonates from detergent mixtures on potassium kaolinite. Colloid Surfactant., v. 40, p. 167-180, 1989.

HUYSMAN, P., VAN MEENEN, P., VAN ASSCHE, P, VERSTRAETE, W. Factors affecting the colonization of non porous and porous parking materials in model upflow methane reactors. Biotechnology Letters, v. 5, n. 9, p. 643-648, 1983.

IM, W., LEE, S.T. Runella sp. P.slu-06 gene for 16S rRNA, partial sequence. Published Only in Database, 2006. 
ISHII, S., SHIMOYAMA, T., HOTTA, Y., WATANABE, K. Characterization of a filamentous biofilm community established in a cellulose-fed microbial fuel cell. BMC Microbiology, v. 8, p. 6, 2008.

IZA, J. Fluidized Bed Reactor for anaerobic wastewater treatment. Water Science Technology, v. 24, n., 8, p. 109-132, 1991.

JIANG,Y.J., XIE,B.G., DENG,Y.J. JS018-a bacteria of degradation organophosphorus pesticide. Trabalho não publicado.

JIN, T., LEE, S., CHEN, G. Investigation of bacterial community in estrogen-degrading membrane bioreactors. Trabalho não publicado.

JU, D.-H., KA, J.-O. Molecular and ecological analyses of microbial community structures in biofilms of a full scale aerated up-flow biobead process. Trabalho não publicado.

KAN,J., EVANS,S.E., CHEN,F., SUZUKI,M.T. Novel estuarine bacterioplankton in rRNA operon libraries from the Chesapeake Bay Source. Aquatic Microbial Ecology. v. 51 n. 1, p. 55-56, 2008.

KANAEBEL, D.B., FEDERIE, T.W., VESTAL, J.R. Mineralization of Linear Alkylbenzene Sulfonate (LAS) and Linear Alcohol Ethoxylate (LAE) in 11 contrasting soils. Environmental Toxicology and Chemistry 9, p. 981-988, 1990.

KHLEIFAT, K.M. Biodegradation of linear alkylbenzene sulfonate by a two-member facultative anaerobic bacterial consortium. Enzyme and Microbial Technology, v. 39, p. 1030-1035, 2006.

KIM, G.T., WEBSTER, G., WIMPENNY, J.W., KIM, B.H., KIM, H.J., WEIGHTMAN, A.J. Bacterial community structure, compartmentalization and activity in a microbial fuel cell. Journal of Applied Microbiology, v. 101, n. 3, p. 698-710, 2006. 
KNAEBEL, D.B., FEDERLE, T.W., VESTAL, J.R. Mineralization of linear alkylbenzene sulfonate (LAS) and linear alcohol ethoxylate (LAE) in 11 contrasting soils. Environmental Toxicology and Chemistry, v. 9, p. 981-988, 1990.

KOLB, F.R., WILDERER, P.A. Activated carbon sequencing batch biofilm reactor to treat industrial wastewater. Water Science and Technology, v. 35, p. 169-176, 1997.

KUBA, T., FURUMAI, H., KUSUDA, T. A kinetic study on methanogenesis by attached biomass in a fluidized bed. Water Research, v. 24, p. 1365-1372, 1990.

KYSELA,R.F., CLEVELAND,C.C., TOWNSEND,A.R., WIEDER,W.R., NEMERGUT,D.R. Soil Bacterial Community Responses to Species-Specific Leaf Litter Dissolved Organic Matter Additions. Trabalho não publicado.

LANE, D.J. 16S/23S rRNA sequencing in nucleic acid techniques. In Bacterial Systematics ed. Stackenbrandt, E. and Goodfellow, M. pp. 115-148. New York: John Wiley and Sons, Inc, 1991.

LAUBER, C.L., STRICKLAND, M.S., BRADFORD, M.A., FIERER, N. The influence of soil properties on the structure of bacterial and fungal communities across land-use types. Trabalho não publicado.

LEE, K., LIU, C., ANZAI, Y., KIM, H., AONO, T., OYAIZU H. The hierarchical system of the 'Alphaproteobacteria': description of Hyphomonadaceae fam. nov., Xanthobacteraceae fam. nov. and Erythrobacteraceae fam. nov. International Journal of Systematic and Evolutionary Microbiology, v. 55, p. 1907-1919, 2005.

LEITE, J.A.C. Produção e extração de ácidos graxos voláteis por fermentação acidogênica em reator anaeróbio horizontal de leito fixo. 2005. Tese de doutorado, EESC, USP, São Carlos.

LESAUlNIER, C., PAPAMICHAIL, D., MCCORKLE, S., OLLIVIER, B., SKIENA, S., TAGHAVI, S., ZAK, D., VAN DER LELIE, D. Elevated atmospheric $\mathrm{CO}_{2}$ affects soil 
microbial diversity associated with trembling aspen. Environmental Microbiology, v. 10, n. 4, p. 926-941, 2008.

LIESEGANG, H., SCHMITZ, J., DANIEL, R. 16SrRNA probes of the river Leine. Trabalho não publicado.

LIM, J.H., BAEK, S.H., LEE, S.T. Ferruginibacter alkalilentus gen. nov., sp. nov. and Ferruginibacter lapsinanis sp. nov., novel members of the family 'Chitinophagaceae' in the phylum Bacteroidetes, isolated from freshwater sediment. International Journal Syst. Evol. Microbiology, v. 59, PT 10, p. 2394-2399, 2009.

LIN, L.-H., HALL, J., ONSTOTT, T.C., GIHRING, T., SHERWOOD LOLLAR, B., BOICE, E., PRATT, L., LIPPMANN-PIPKE, J., BELLAMY, R.E.S. Planktonic microbial communities associated with fracture-derived groundwater in a deep gold mine of South Africa. Geomicrobiology Journal, v. 23, n. 6, p. 475-497, 2006.

LIPSON,D.A., WILSON,R.F., OECHEL,W.C. Effects of elevated atmospheric CO2 on soil microbial biomass, activity, and diversity in a chaparral ecosystem. Applyed Environmental Microbiology v. 71 n. 12, p. 8573-8580, 2005.

LIU, J.R., BURRELL, P., SEVIOUR, E.M., SODDELL, J.A., BLACKALL, L.L., SEVIOUR, R.J. The filamentous bacterial morphotype 'Nostocoida limicola' I contains at least two previously described genera in the low G+C gram positive bacteria. Systematic and Applied Microbiology , v.23, n. 4, p. 528-534, 2000.

LOBNER, T., TORÄNG, L., BATSTONE, D.J., SCHMIDT, J.E., ANGELIDAKI, I. Effects of process stability on anaerobic biodegradation of LAS in UASB reactors. Biotechnology and Bioengineering, v. 89, p. 759-765, 2005.

LUKOW, T. Vergleichende Charakterisierung der bakteriellen Rhizosphaerengemeinschaften transgener versus nicht-transgener Kartoffelpflanzen. Trabalho não publicado.

LUO,H.Q., HU,Y.Y. The use of $16 \mathrm{~S}$ rDNA clone libraries to study microbial communities of ANAMMOX sludge. Trabalho não publicado. 
MA, Y.L., ZHAO, J.L., YANG, B.L. Removal of $\mathrm{H}_{2} \mathrm{~S}$ in waste gases by an actived carbon bioreactor. International Biodeterioration \& Biodegradation, v. 57, p. 93-98, 2006.

MAINTINGUER, S. I. Degradação anaeróbia de fenol sob diferentes condições nutricionais. 2004. Dissertação de Mestrado, EESC, USP, São Carlos.

MAKI,T., HASEGAWA,H., UEDA,K. Classification of dimethylarsenate decomposing bacteria using restrict fragment length polymorphism analysis of 16S rRNA genes. Trabalho não publicado.

MAKI,T., YOSHINAGA,I., IMURA,K., HIROTA,W., KAKIMOTO,T., SHIMADA,T., HASEGAWA,H., UEDA,K. The dynamics of bacterial composition at the microbial degradation process of dimethylarsinic acid in Lake Kahokugata. Trabalho não publicado.

MANOUSAKI, E., PSILLAKIS, E., KALOGERAKIS, N., MANTZAVINOS, D. Degradation of sodium dodecylbenzene sulfonate in water by ultrasonic irradiation. Water Research, v. 38, p. 3751-3759, 2004.

MARGULIS, L., SCHWARTZ, K.V. Five Kingdoms. An Illustrated Guide to the Phyla of Life on Earth. W.H. Freeman, New York, 1998

MATTHIJS, E., DE HENAU, H. Determination of linear alkylbenzene sulfonates in aqueous samples, sediments, sludges and soils using HPLC. Tenside Surfactants Detergents, v. 24, p. 193-198, 1987.

MCILROY, S.J., HOEFEL, D., AHN, J., SEVIOUR, R.J. FACS of an EBPR SBR. Trabalho não publicado

MECHICHI,T., STACKEBRANDT,E., GAD'ON,N., FUCHS,G. Phylogenetic and metabolic diversity of bacteria degrading aromatic compounds under denitrifying conditions, and description of Thauera phenylacetica sp. nov., Thauera aminoaromaticasp. nov., and Azoarcus buckelii sp. nov. Archieves Microbiology v. 178 n. 1, p. 26-35, 2002. 
MENSAH, K.A., FORSTER, C.F. An examination of the effects of detergents on anaerobic digestion. Bioresource Technology, v. 90, p. 133-138, 2003.

MESSING, J. Methods in Enzymology, v. 101, p. 20-78, 1983.

Militon, C., Boucher, D., Troquet, J., PEYREtaillade, E., PEYRET, P. Dynamics of the bacterial communities during a pilot-scale bioremediation process of a hydrocarbon-contaminated soil identified by SSU rDNA and SSU rRNA libraries. Trabalho não publicado.

MOGENSEN, A.S., HAAGENSEN, F., AIIRING, K. Anaerobic degradation of linear alkylbenzene sulfonate. Environmental Toxicology and Chemistry, v. 22, p. 706-711, 2003.

MOHN,W.W. Bacteria obtained from a sequencing batch reactor that are capable of growth on dehydroabietic acid. Applyed Environmental Microbiology v. 61 n. 6, p. 2145-2150, 1995.

MOHR, K.I., TEBBE, C.C. Diversity and phylotype consistency of bacteria in the guts of three bee species (Apoidea) at an oilseed rape field. Environmental Microbiology, v. 8, n. 2, p. 258-272, 2006.

MORALES, S.E., COSART, T.F., JOHNSON, J.V., HOLBEN, W.E. Extensive phylogenetic analysis of a soil bacterial community illustrates extreme taxon evenness and the effects of amplicon length, degree of coverage, and DNA fractionation on classification and ecological parameters. Applyed Environmental Microbiology v. 75 n. 3, p. 668-675, 2009.

MUDARRIS, M., AUSTIN, B., SEGERS, P., VANVANNEYT, M., HOSTE, B., BERNERDET, F. Flavobacterium scophthalmum sp. nov., a Pathogen of Turbot (Scophthalmus maximus L.). International Journal of Systematic Bacteriology, v. 44, n. 3, p. 447-453, 1994.

MUHLING,M., WOOLVEN-ALLEN,J., MURRELL,J.C., JOINT,I. Improved group-specific PCR primers for denaturing gradient gel electrophoresis analysis of the genetic diversity of complex microbial communities. ISME J v. 2, n. 4, p. 379-392, 2008. 
MUKHERJEE,S., KUMAR,D., CHAKRABORTY,R. Looking into eubacterial diversity in Mahananda river, India, using metagenomic approach. Trabalho não publicado.

MULCAHY, L.T., SHIEH, W.K. Fluidization and reactor biomass characteristics of the denitrification fluidized bed biofilm reactor. Water Research, v. 21, 451-458, 1987

MUNGRAY, A.K., KUMAR, P. Degradation of anionic surfactants during drying of UABSR sludges on sand drying beds. Journal of Environmental Management, v. 88, p. 995-1002, 2008.

MUNSHI, T.K., CHATTOO, B.B. Bacterial population structure of the jute-retting environment. Microbial Ecology, v. 56, n. 2, p. 270-282, 2008.

MURASE,J., ITO,K., KANO,M., KIMURA,M. Molecular analysis of beta-proteobacterial ammonia oxidizer populations in a submerged paddy soil microcosm. Trabalho não publicado.

NELSON, C.E. Phenology of high-elevation pelagic bacteria: the roles of meteorologic variability, catchment inputs, and thermal stratification in structuring communities. Trabalho não publicado.

NEMERGUT, D.R., ANDERSON, S.P., CLEVELAND, C.C., MARTIN, A.P., MILLER, A.E., SEIMON, A., SCHMIDT, S.K. Microbial community succession in an unvegetated, recently deglaciated soil. Microbial Ecology, v. 53 n. 1, p. 110-122, 2007.

NESTLER, H., KIESEL, B., KASCHABEK, S.R., MAU, M., SCHLOMANN, M. ANDBALCKE, G.U. Biodegradation of chlorobenzene under hypoxic and mixed hypoxicdenitrifying conditions. Biodegradation, v. 18, n. 6, p. 755-767, 2007.

NG, A., STENSTROM, K., MARRS, D.R. Nitrification enhancement in the powdered activated carbon-activated sludge process for the treatment of petroleum refinery wastewaters. Journal of Water Pollution Control Federation, v. 59, p. 199-211, 1987. 
NGUYEN, H.B., DANG,H. T.C., PIEPER, D.H. Change of microbial community composition in toxic chemical contaminated soil bioremediation field trial at small scale. Trabalho não publicado.

NIU, S.Q., FUKUSHIMA, J., JIANG, Y., ISHIKAWA, Y., UEDA, T., MATSUMOTO, S. Analysis of Bacterial Community Structure in the Natural Circulation System Wastewater Bioreactor by Using a 16S rRNA Gene Clone Library. Microbiology Immunology, v. 50, n. 12, p. 937-950, 2006.

NOGALES, B., MOORE, E.R., LLOBET-BROSSA, E., ROSSELLO-MORA, R., AMANN, R., TIMMIS, K.N. Combined use of $16 \mathrm{~S}$ ribosomal DNA and 16S rRNA to study the bacterial community of polychlorinated biphenyl-polluted soil. Applied and Environmental Microbiology, v. 67, n. 4, p. 1874-1884, 2001.

NUSWANTARA, S., FUJIE, M., YAMADA, T., MALEK, W., INABA, M., KANEKO, Y., MUROOKA, Y. Phylogenetic position of Mesorhizobium huakuii subsp. regei, a symbiont of Astragalus sinicus cv. Japan. Journal of Bioscience and Bioengineering, v. 87, p. 49-55, 1999.

OCEGUERA-CERVANTES, A., CARRILlO-GARCIA, A., LOPEZ, N., BOLANOSNUNEZ, S., CRUZ-GOMEZ, M.J., WACHER, C., LOZA-TAVERA, H. Characterization of the Polyurethanolytic Activity of Two Alicycliphilus sp. Strains Able To Degrade Polyurethane andN-Methylpyrrolidone. Applied and Environmental Microbiology, v. 73, n. 19, p. 6214-6223, 2007.

OKADA, D.Y. Degradação de alquilbenzeno linear sulfonado (LAS) em reator anaeróbio de leito fluidificado. 2007. Trabalho de Graduação Integrado, UFSCar, USP, São Carlos.

OLIVEIRA, L.L. Influência do Material Suporte na Degradação de Alquilbenzeno Linear Sulfonado (LAS) em Reator Anaeróbio. 2006. Dissertação de Mestrado, EESC, USP, São Carlos. 
OLIVEIRA, L.L., DUARTE, I.C.S., SAKAMOTO, I.K., VARESCHE, M.B.A. Influence of support material on the immobilization of biomass for the degradation of linear alkylbenzene sulfonate in anaerobic reactors. Journal of Environmental Management, v. 90, p. 12611268, 2009.

ONSTOTT, T.C., MOSER, D.P., PFIFFNER, S.M., FREDRICKSON, J.K., BROCKMAN, F.J., PHELPS, T.J., WHITE, D.C., PEACOCK, A., BALKWILL, D., HOOVER, R., KRUMHOLZ, L.R., BORSCIK, M., KIEFT, T.L., WILSON, R. Indigenous and contaminant microbes in ultradeep mines. Environmental Microbiology, v. 5, n. 11, p. 1168-1191, 2003.

ORSHANSKY, F., NARKIS, N. Characteristics of organics removal by PACT simultaneous adsorption and biodegradation. Water Research, v. 31, p. 391-398, 1997.

OSAKA, T., EBIE, Y., TSUNEDA, S., INAMORI, Y. Identification of the bacterial community involved in methane-dependent denitrification in activated sludge using DNA stable-isotope probing. FEMS Microbiology Ecology, v. 64, n. 3, p. 494-506, 2008.

OU, Z, YEDILER, A, HE, Y, JIA, L, KETTRUP, A, SUN, T. Adsorption of Linear Alkylbenzene Sulfonate (LAS) on Soils. Chemosphere, v.32, n. 5, p. 827-839, 1996.

PACE, N. 16S rRNA gene sequences from showerhead swabs and water samples. Trabalho não publicado.

PAINTER, H.A., ZABEL, T. The behaviour of LAS in sewage treatment. Tenside Surfactants Detergents, v. 26, p. 108-115, 1989.

PAKARINEN, J., HYVARINEN, A., SALKINOJA-SALONEN, M., LAITINEN, S., NEVAlAinEN, A., MAKELA, M.J., HAAHTELA, T., VON HERTZEN, L. Predominance of Gram-positive bacteria in house dust in the low-allergy risk Russian Karelia. Environmental Microbiology, v. 10, n. 12, p. 3317-3325, 2008.

PANNU, J.K., SINGH, A., WARD, O.P. Influence of peanut oil on microbial degradation of polycyclic aromatic hydrocarbons. Canadian Journal of Microbiolology, v. 49, p. 508-513, 2003. 
PARKIN, G.F., SPEECE, R.E., Attached versus suspended growth anaerobic reactors: response to toxic substances. Water Science Technology, v. 15, p. 261-289, 1983.

PEREZ, M., ROMERO, L.I., SALES, D. Comparative performance of high rate anaerobic thermophilic technologies treating industrial wastewater. Water Research, v. 32, p. 559-564, 1998.

PEREZ, M., ROMERO, L.I., SALES, D. Organic matter degradation kinetics in an anaerobic thermophilic fluidised bed bioreactor. Anaerobe, v. 7, p.25-35, 2001.

PERKINS,E.J., KENNEDY,A.C. Monitoring Effects on Soil Ecology using 16S rDNA of Native Ammonia-Oxidizing Bacteria as Indicator Species. Trabalho não publicado.

PHUNG, N.T., LEE, J., KANG, K.H., CHANG, I.S., GADD, G.M., KIM, B.H. Analysis of microbial diversity in oligotrophic microbial fuel cells using 16S rDNA sequences. FEMS Microbiology Letter, v. 233, n. 1, p. 77-82, 2004.

PIMENTEL, J.D., DUBEDAT, S.M., DODDS, E.L., BENN, R.A. Identification of Isolates within the Burkholderia cepacia Complex by a Multiplex recA and 16S rRNA Gene RealTime PCR Assay. Journal of Clinical Microbiology, v. 45, n. 11, p. 3853-3854, 2007.

QIN,H., WANG,X., WU,M., CHEN,Z., CHEN,C., WEI,W. Phylogenetic Analysis of 16S rDNA Sequences of Paddy Soil Under Long-term Fertilization. Trabalho não publicado.

QU, J.H., YUAN, H.L. Sediminibacterium salmoneum gen. nov., sp. nov., a member of the phylum Bacteroidetes isolated from sediment of a eutrophic reservoir. International Journal of Systematic and Evolutionary Microbiology, v. 58, n. 9, p. 2191-2194, 2008.

RAWLS,J.F., SAMUEL,B.S., GORDON,J.I. Gnotobiotic zebrafish reveal evolutionarily conserved responses to the gut microbiota. Proc. Natl. Acad. Sci. U.S.A., v. 101, n. 13, p. 4596-4601, 2004. 
RINTAlA, H., PITKARANTA, M., TOIVOLA, M., PAUlin, L., NEVALAINEN, A. Diversity and seasonal dynamics of bacterial community in indoor environment. BMC Microbiology, v. 8, p. 56, 2008.

RIPLEY, L.E., BOYLE, W.C. CONVERSE, L.C. Improved alkalinetric monitoraing for anaerobic digestion of high-strength wastes. Journal WPCF. v. 58, p. 106-411, 1986.

RUI, J., PENG, J., LU, Y. Succession of bacterial populations during plant residue decomposition in rice field soil. Trabalho não publicado.

SADER, L.T. E SILVA, E.L. Desenvolvimento de biofilme em partículas poliméricas como meio suporte em reator anaeróbio de leito fluidificado no tratamento de fenol. Anais do IV Seminário do Projeto Temático - Desenvolvimento, análise, aprimoramento e otimização de reatores anaeróbios para tratamento de águas residuárias, p. 265-271, 2005.

SAKAMOTO, I.K. Comportamento do consórcio microbiano existente em um lodo granulado anaeróbio metanogênico submetido a adições crescentes de sulfato. 1996. Dissertação de mestrado, EESC, USP, São Carlos.

SAKANO,Y., STROM,P., KERKHOF,L. Microbial genetic analysis of the rhizoplanes of five candidate crops and two growth media use in advanced life support systems. Trabalho não publicado.

SAKANO, Y., PICKERING, K.D., STROM, P.F., KERKHOF, L.J. Spatial distribution of total, ammonia-oxidizing, and denitrifying bacteria in biological wastewater treatment reactors for bioregenerative life support. Applied and Environmental Microbiology, v. 68, n. 5 , p. 2285-2293, 2002.

SANZ, I., POLANCO, F. Low temperature treatment of municipal sewage in anaerobic fluidized bed reactors. Water Research, v. 24 n. 4, p. 463-469, 1990.

SANZ, J.L., CUlUBRET, E., FERRER, J. DE, MORENO, A., BERNA, J.L. Anaerobic biodegradation of linear alkylbenzene sulfonate (LAS) in upflow anaerobic sludge blanket (UASB) reactor. Biodegradation, v. 14, p. 57-64, 2003. 
SARAVANAN, V., SREEKRISHNAN, T.R. Modelling anaerobic biofilm reactors - A review. Journal of Environmental Management, v. 81, p. 1-18, 2006.

SCHLOSS, P.D., HANDELSMAN, J. Introducing DOTUR, a Computer Program for Defining Operational Taxonomic Units and Estimating Species Richness. Applied and Environmental Microbiology, v. 71, n. 3, p. 1501-1506, 2005.

SCHÖBERL, P. Basic principles of LAS biodegradation. Tenside Surfactants Detergents, v. 26, p.86-94, 1989.

SCHWARZ, J.I.K., ECKERT, W., CONRAD, R. Response of a microbial community in a profundal lake sediment (Lake Kinneret, Israel) to a simulated algal sedimentation event. Trabalho não publicado.

SCOTT, M.J., JONES, M.N. The biodegradation of surfactants in the environment. Biochimica et Biophysica Acta, v. 1508, p. 235-251, 2000.

SEM, S., DEMIRER, G.N. Anaerobic treatment of real textile wastewater with a fluidized bed reactor. Water Research, v. 37, p. 1868-1878, 2003.

SEVERO, L.C., RITTER, P., PETRILlO, V.F., DIAS, C.A.G., PORTO, N.S. Infecção pulmonar por Rhodococcus equi: relato dos dois primeiros casos brasileiros. Jornal de Pneumologia, v. 27, n. 3, 2001.

SILVA, A.J., HIRASAWA, J.S., VARESCHE, M.B., FORESTI, E., ZAIAT, M. Evaluation of support materials for the immobilization of sulfate-reducing bacteria and methanogenic archaea. Anaerobe, v. 12, p. 93-98, 2006.

SILVA,C.C., JESUS,E.C., SOUSA,M.P., $\quad$ TORRES,A.P.R., $\quad$ SANTIAGO,V.M.J., OLIVEIRA,V.M. Investigation of bacterial diversity in membrane bioreactor and conventional activated sludge processes from petroleum refineries using phylogenetic and statistical approaches. Trabalho não publicado. 
SILVA, E.L. Tratamento aerobio de fenol em reator de leito fluidificado trifasico. 1985. Tese de Doutorado, EESC, USP, São Carlos.

SINGH, R.P., GUPTA, N., SINGH, S., SINGH, A., SUMAN, R., ANNIE, K. Toxicity of ionic and non-ionic surfactants to six microbes found in Agra, India. Bulletin of Environmental Contamination and Toxicology, v. 69, p. 265-270, 2002.

SINKKO,H., LUKKARI,K., JAMA,A.S., SIHVONEN,L.M., SIVONEN,K., LEIVUORI,M., RANTANEN,M., PAULIN,L., LYRA,C. Changes in bacterial community composition along nutrient gradients in northeastern Baltic Sea sediments receiving agricultural discharges. Trabalho não publicado.

SIROTKIN, A.S., KOSHKINA, L.Y., IPPOLITOV, K.G. The BAC process for treatment of wastewater containing non-ionic synthetic surfactants. Water Research, v. 35, p. 3265-3271, 2001.

SUESCUN, A.V., JIMENEZ, M.T., REYES, A., ZAMBRANO, M.M. Bacterial Community Analysis of the Bogota River. Trabalho não publicado.

TAKASAKI,K., ICHIKAWA,N., MIURA,H., MATSUSHITA,S., WATANABE,Y., OGUCHI,A., ANKAI,A., YASHIRO,I., TAKAHASHI,M., TERUI,Y., FUKUI,S., YOKOYAMA,H., TANIKAWA,S., HANADA,S., KAMAGATA,Y., FUJITA,N. Complete genome sequence of Gemmatimonas aurantiaca T-27T that represents a novel phylum Gemmatimonadetes. Trabalho não publicado.

TANG, K., BASKARAN, V., NEMATI, M. Bacteria of the sulphur cycle: An overview of microbiology, biokinetics and their role in petroleum and mining industries. Biochemical Engineering Journal, v. 44, p. 73-94, 2009.

TELH, M. Avaliação do uso de reator anaeróbio horizontal de leito fixo no tratamento de vinhaça sob condições termofílicas. 2001. Dissertação de Mestrado, EESC, USP, São Carlos. 
TIIROLA,M.A., SAANO,A., KULOMAA,M.S. Potential of DGGE and length heterogeneity analysis of $16 \mathrm{~S}$ rDNA in screening the microbial diversity in chlorophenol degrading bioreactor. Trabalho não publicado.

TOMARAS, J., SAHL, J.W., SIEGRIST, R.L., SPEAR, J.R. Microbial diversity of septic tank effluent and the soil biozone. Trabalho não publicado.

TOMCZYK-ZAK, K. Rock biofilm from a gold mine with unusually high microbial diversity. Trabalho não publicado

TORRES, P. Desempenho de um reator anaeróbio de manta de lodo (UASB) de bancada no tratamento de substrato sintético simulando esgoto sanitário sob diferentes condições de operação. 1992. Dissertação de Mestrado, EESC, USP, São Carlos.

TRINGE, S.G., VON MERING, C., KOBAYASHI, A., SALAMOV, A.A., CHEN, K., CHANG, H.W., PODAR, M., SHORT, J.M., MATHUR, E.J., DETTER, J.C., BORK, P., HUGENHOLTZ, P., RUBIN, E.M. Comparative metagenomics of microbial communities. Science, v. 308, n. 5721, p. 554-557, 2005.

URRUTIA, H., VIDAL, R., BAEZA, M., ASPE, E. Effect of fishing industries effluents pH and oganic load on the methanogenic bacteria biofilm developed over support in fixed biomass reactor. Anaerobe, v. 5, p. 325-327, 1999.

VARESCHE, M.B.A., ZAIAT, M., VIEIRA, L.G.T., VAZOLLER, R.F., FORESTI, E. Microbial colonization of polyurethane foam matrices in horizontal-flow anaerobic immobilized-sludge reactor. Applied Microbiology and Biotechnolog y, v. 48, p. 534-538, 1997.

WAGNER, M., HORN, M. The Planctomycetes, Verrucomicrobia, Chlamydiae and sister phyla comprise a superphylum with biotechnological and medical relevance. Current Opinion in Biotechnology, v. 17, p. 241-249, 2006.

WALKER, G.M., WEATHERLEY, L.R. Biological activated carbon treatment of industrial wastewater in stirred tank reactors. Chemical Engineering Journal, v. 75, p. 201-206, 1999. 
WANG, A., REN, N., SHI, Y., LEE, D.-J., BAO, H. Bioaugmented hydrogen production from microcrystalline cellulose using co-culture Clostridium acetobutylicum X9 and Ethanoigenens harbinense B49. International Journal of Hydrogen Energy, v. 33, n. 2, p. 912-917, 2008.

WATANABE, K., KOMATSU, N., ISHII, Y., PARK, H., NEGISHI, M. Isolation of freshwater bacterioplankton. Trabalho não publicado.

WEELINK,S.A., TAN,N.C., TEN BROEKE,H., VAN DOESBURG,W., LANGENHOFF,A.A., GERRITSE,J., STAMS,A.J. Physiological and phylogenetic characterization of a stable benzene-degrading, chlorate-reducing microbial community. FEMS Microbiology Ecology. v. 60, n. 2, p. 312-321, 2007.

WHITEHEAD, T.R., COTTA, M.A. Characterization of Microbial Populations in Swine Feces and Manure Storage Pits by $16 \mathrm{~S}$ rDNA Gene Sequence Analyses. Trabalho não publicado

WIDDEL, F. Microbiology and ecology of sulfate- and sulfur-reducing bacteria. Biology of Anaerobic Microorganisms, Edited by Zehnder, A.J.B., John Wiley \& Sons, 1988.

WILLIAMS, M.M., SANTO DOMINGO, J.W. Population diversity in model drinking water biofilms receiving chlorine or monochloramine residual. Trabalho não publicado.

WILLIAMS,M.M., DOMINGO,J.W., MECKES,M.C., KELTY,C.A., ROCHON,H.S. Phylogenetic diversity of drinking water bacteria in a distribution system simulator. Journal of Appyed Microbiology, v. 96, n. 5, p. 954-964, 2004.

XIE,C.H., YOKOTA,A. Zoogloea oryzae sp. nov., a nitrogen-fixing bacterium isolated from rice paddy soil, and reclassification of the strain ATCC 19623 as Crabtreella saccharophila gen. nov., sp. nov. International. Journal. Systematic. Evolution. Microbiology v.56 PT 3, p. $619-624,2006$ 
YABUUCHI, E., KANEKO, T., YANO, I., MOSS, C.W., MIYOSHI, N. Sphingobacterium gen. nov., Sphingobacterium spiritivorum comb. nov., Sphingobacterium multivorum comb. nov., Sphingobacterium mizutae sp. nov., and Flavobacterium indologenes sp. nov. : GlucoseNonfermenting Gram-Negative Rods in CDC Groups IIK-2 and IIb. International Journal of Systematic Bacteriology, v. 33, n. 3, p. 580-598, 1983.

YAMADA, T., SEKIGUCHI, Y., HANADA, S., IMACHI, H., OHASHI, A., HARADA, H., KAMAGATA, Y. Anaerolinea thermolimosa sp. nov., Levilinea saccharolytica gen. nov., sp. nov. and Leptolinea tardivitalis gen. nov., sp. nov., novel filamentous anaerobes, and description of the new classes Anaerolineae classis nov. and Caldilineae classis nov. in the bacterial phylum Chloroflexi. International Journal of Systematic and Evolutionary Microbiology, v. 56, p. 1331-1340, 2006.

YAMADA, T., YAMAUCHI, T., SHIRAISHI, K., HUGENHOLTZ, P., OHASHI, A., HARADA, H., KAMAGATA, Y., NAKAMURA, K., SEKIGUCHI1, Y. Characterization of a filamentous biofilm community established in a cellulose-fed microbial fuel cell. BMC Microbiology, v. 8, p. 6, 2008.

YANG, Y., TADA, C., MIAH, M.S., TSUKAHARA, K., YAGISHITA, T., SAWAYAMA, S. Influence of bed material on methanogenic characteristcs and immobilized microbes in anaerobic digester. Materials Science \& Engineering C. v. 24, p. 413-419, 2004.

YING, G.-G. Fate, behavior and effects of surfactants and their degradation products in the environment. Environmental International, v. 32, p. 417-431, 2006.

YOON,J.H., KANG,S.J., PARK,S., LEE,S.Y., OH,T.K. Reclassification of Aquaspirillum itersonii and Aquaspirillum peregrinum as Novispirillum itersonii gen. nov., comb. nov. and+E44 Insolitispirillum peregrinum gen. nov., comb. nov. International. Journal. Systematic Evolution Microbiology v. 57, PT 12, p. 2830-2835, 2007.

YU, C.-P., FARRELL, S.K., CHU, K.-H. Q-FAST: A Quantitative Assay for Linking Microbial Community Function and Structure in Environmental Samples. Trabalho não publicado. 
ZAIAT, M., CABRAL, A.K.A., FORESTI, E. Reator anaeróbio de leito fixo para tratamento de águas residuárias: concepção e avaliação preliminar de desempenho. Revista Brasileira de Engenharia - Caderno de Engenharia Química, v. 11, p. 33-42, 1994.

ZHU,N.W., GUO,Y. Molecular phylogenetic diversity of bacteria in hot sewage sludge compost. Trabalho não publicado. 


\section{APÊNDICE A}

Em trabalho realizado por Okada (2007), a isoterma de adsorção de carvão ativado similar ao utilizado no presente trabalho foi obtida por meio de ensaio de adsorção em batelada com o material suporte em contato com soluções de LAS variando sua concentração inicial de 2,5 a $40 \mathrm{mg} / \mathrm{L}$. Ao término do ensaio foram coletadas amostras do sobrenadante. Os dados obtidos foram ajustados à equação de Freundlich conforme a seguir:

$$
S=0,01 \cdot C^{0,8977}
$$

$$
\mathrm{R}^{2}=0,9923
$$

Onde,

$\mathrm{S}=$ massa de LAS por massa de carvão $\quad$ (mg LAS/g carvão)

$\mathrm{C}=$ concentração de LAS $\quad$ (mgLAS/L)

Utilizando os cálculos de isoterma e sólidos (Tabela A.1) realizados por Okada, podese estimar a massa de LAS possivelmente adsorvida à biomassa efluente do reator.

Tabela A.1: Valores de sólidos para carvão ativado em reator de leito fluidificado

\begin{tabular}{ccc}
\hline $\begin{array}{c}\text { SV por massa de material } \\
(\mathbf{g S V} / \mathbf{g})\end{array}$ & $\begin{array}{c}\text { SV do carvão sem biomassa } \\
(\mathbf{g S V} / \mathbf{g})\end{array}$ & $\begin{array}{c}\text { SV biomassa } \\
(\mathbf{g S V} / \mathbf{g})\end{array}$ \\
\hline 0,12 & 0,11 & 0,01 \\
\hline
\end{tabular}

SV: sólidos voláteis

Fonte: Okada, 2007.

No balanço final do reator, pela isoterma de adsorção, estima-se que 7,7 mg de LAS ficariam adsorvidos ao suporte. Experimentalmente, a extração de LAS do suporte + biofilme ao final da operação revelou que $34 \mathrm{mg}$ de LAS ficaram adsorvidos (Tabela 5.10). A diferença entre esses valores, representa $8 \%$ de todo o LAS adicionado ao reator.

No caso dos reatores preenchidos com argila expandida (R2), pérolas de vidro (R3) e areia (R4 e escala de bancada), experimentalmente, constatou-se que não houve adsorção do LAS ao suporte e biofilme no final da operação (Tabelas 5.10 e 5.11). 
